\title{
THE ELECTROCHEMICAL PHOTOEFFECT
}

Michael Heyrovský

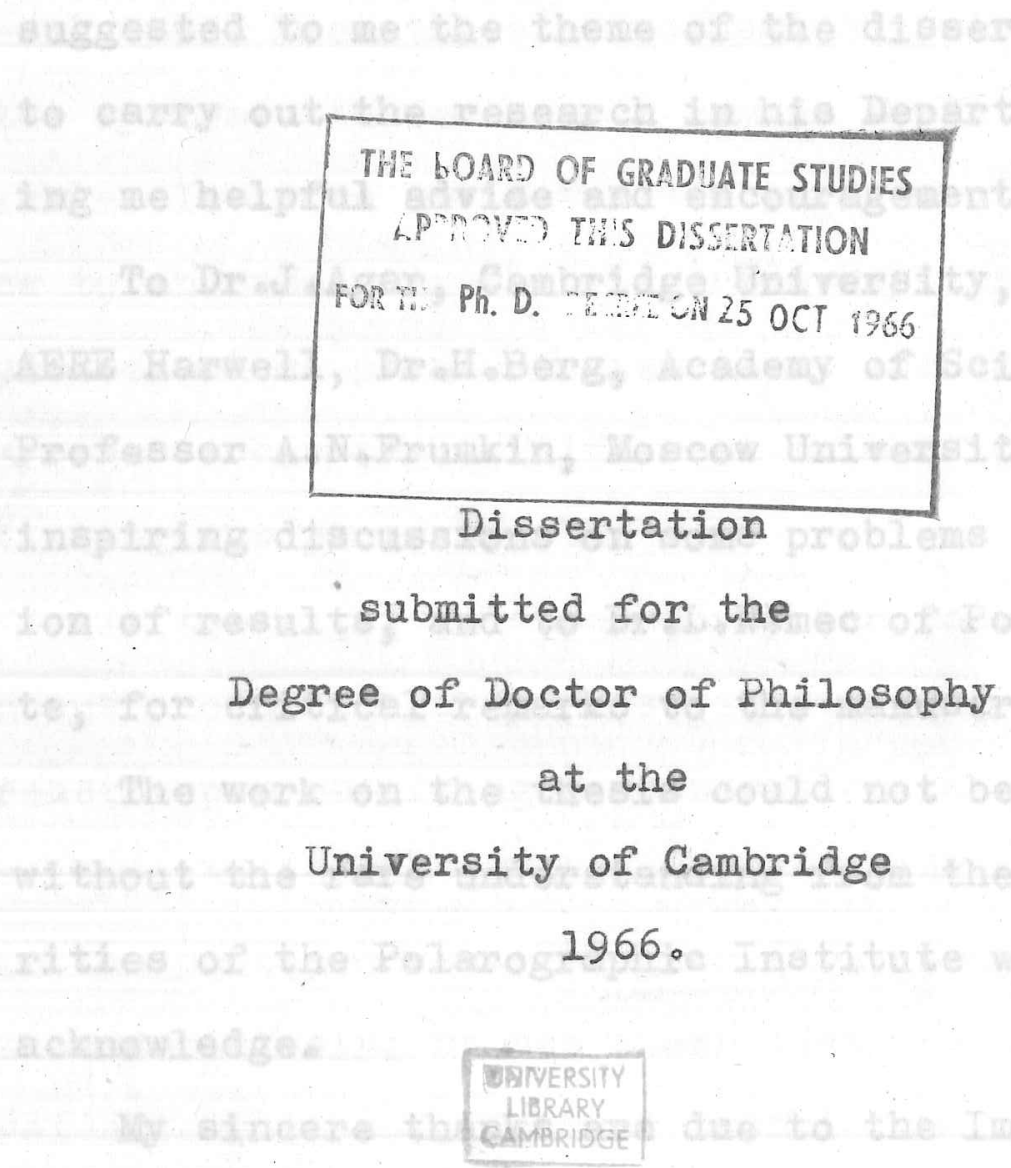




\section{Preface}

The experimental part of the work on this thesis was done in the years 1962, 1964 and in Lent Term 1965 at the Department of Physical Chemistry of Cambridge University under the supervision of Frofessor R.G.W.Norrish, F.R.S., and the writing was accomplished in the Institute of Polarography, Czechoslovak Academy of Sciences, Prague, in Spring 1966.

I am greatly indebted to Professor R.G.W.Norrish who suggested to me the theme of the dissertation, enabled me to carry out the research in his Department, and was giving me helpful advice and encouragement during the work.

To Dr.J.Agar, Cambridge University, Dr.G.C.Barker, AERE Harwell, Dr.H॰Berg, Academy of Sciences, Jena, and Professor A.N.Frumkin, Moscow University, I am obliged for inspiring discussions on some problems of the interpretation of results, and to Dr.L.Nëmec of Polarographic Institute, for critical remarks to the manuscript.

The work on the thesis could not be brought to end without the rare understanding from the side of the authorities of the Polarographic Institute which I thankfully acknowledge.

My sincere thanks are due to the Imperial Chemical Industries Itd., to the British Petroleum Company and to Pembroke College, Cambridge, for financial support in the course of research. 


\section{Introduction}

The effects observed when an electrode in solution is exposed to light have been a subject of research since Edmond Becquerel's discovery ${ }^{I}$ in 1839. Most of the papers published in this field were reviewed by Copeland, Black and Garret ${ }^{2}$; more recent ones are quoted in articles by Paszyc ${ }^{3}$ and by Mauser and Sproesser ${ }^{4}$.

A study of these effects must consider both electrochemical and photochemical properties of the system electrode-solution. From the electrochemical point of view most of the systems studied have a common basic scheme : a polarizable electrode indicates the effects of light in reference to an unpolarizable electrode kept in dark. From the photochemical point of view there are three main types of systems according to different primary photoreactions initiating the photoeffect.

If the light is absorbed by the solution and a homogeneous.photochemical process is started, the electrode only reacts upon resulting concentration changes of electroactive species in the solution without taking appreciable part in the photoprocess. Trumpler ${ }^{5}$ was the first who proved this decisively; he has shown that the cause of the Becquerel effect in solutions of uranyl- and uranium sulphate must be sought in photochemistry of uranium. In such cases photolytic reactions in solutions can be conveniently studied by electrochemical methods from the effect of light on the course of potential (under the galvanostatic regime) 
or current (in a potentiostatic arrangement). Rideal and Norrish ${ }^{6}$ followed potentiometrically the photodecomposition of potassium permanganate. Rabinowitch 7 who later applied the same technique for investigation of photochemical reaction of thionine with ferrous ion, suggested the name "photogalvanic effect" for this "special case of the so-called Becquerel effect in which the influence of light $\ldots$ is due to a photochemical process in the body of the electrolyte (as distinct from photochemical or photoelectric processes in the surface layer of the electrode, which are the basis of the original Becquerel effect)". Surash and Hercules 8 showed that the changes of potential on illumination of a platinum electrode in ethanilic solutions of organic compounds are due to free radicals formed by photochemical reactions between the solute and the solvent independently of the electrode and demonstrated a parallelism between the absorption spectrum of the solution and the photopotential. Mauser and Sproesser ${ }^{4}$ examined some 120 solutions of organic compounds in non-aqueous solvents and concluded that photochemically inactive systems are also Becquerel-inactive. The polarographic method has been utilized for the study of photochemical reactions by Berg 9 and coworkers ${ }^{10}$; the "photoreaction-controlled diffusion currents" and "photokinetic currents" which they observed on illumination of solutions of organic compounds surrounding the dropping mercury electrode correspond to "photopotentials" followed potentiometrically by other authors with solid electrodes. 
A different process occurs in the system : nonabsorbing solution - photosensitive electrode. A correct interpretation of this kind of Becquerel effect was first given by Volmer and Moll ${ }^{11}$ on basis of their experiments with selenium electrode : the primary reaction after absorption of light by the electrode is the setting free of inner electrons in the electrode followed by chemical reactions in which both the electrode and the solution take part. A more concise formulation - internal photoeffect followed by chemical reactions - was used by Athanasiu ${ }^{12}$ who studied the effect of light on silver, mercury and copper electrodes covered by layers of halides, sulphides or oxides. Later Veselovsky 13 in a paper on the photoelectrochemical process at zinc electrode covered with zinc oxide defined precisely that the absorption of light by the electrode surface leads to formation of electrons and holes of high energy which migrate to the interfaces metalsemiconductor and semiconductor-solution respectively where they are electrochemically discharged.

For many years the general distinction between these two basically different processes was obscured by the search for some common principle that would apply universally to all modifications of the Becquerel effect. In the early years of research on that field it was difficult to judge the problems correctly, because most of the systems, usualIy very complex, were studied without knowledge of their optical and photochemical properties, the measurements were carried out in presence of air and experimental condi- 
tions were not always properly controlled. As late as in 1927 Winther 14 unambiguously distinguished. between the "volume photoeffect" and the effect for which an illumination of the electrode is essential; only for the latter he suggested to keep the name "Becquerel effect".

The majority of experimental results reported in literature can be ascribed to either of the two effects or to their combination. However, a difficulty arises with the system of pure metaliic electrode in transparent solution where neither part is "photosensitive" in the current sense of the word, but which, nevertheless, can yield a reproducible response to illumination. The offhand explanation by an outer photoeffect, $1 . e$. by emission of electrons from the electrode was usually discarded by the authors as it was thought in iconsistent with their experimental results. Swensson 15 followed the potential changes of platinum electrode in solutions of various electrolytes on illumination by a mercury lamp, and found marked effects with compounds usually not considered as photochemically active, like $\mathrm{H}_{2} \mathrm{SO}_{4}$ or KCI. His results were confirmed by Lifschitz and Hooghoudt ${ }^{16}$. Audubert ${ }^{17}$ studied the effect of visible light on polarized platinum and gold electrodes in various solutions and expressed the view that photolysis of water could be responsible for the observed phenomena. Unfortunately neither of these authors took into due consideration the absorption of light by the solution and consequently it cannot be decided to what extent their effects 
should be ascribed to homogeneous photoreactions.

An important discovery was made by Bowden 18 who found that the electrodepositions of hydrogen on mercury electrode and of oxygen on platinum electrode are accelerated by UV light. The increment of current produced by illumination, or photocurrent, increases with increasing gatsve potential and with light of shorter wavelengths. Bowden's effect was further studied by Price ${ }^{19}$ on various electrodes (bismuth, cobalt, antimony, mercury, lead, aluminium, graphite). Price showed that the photocurrent is directly proportional to the intensity of light, and that the quantum yield of photocurrent is an exponential function both of potential of electrode and of frequency of light. Hillson and Rideal 20 confirmed the results of Price. They studied the electrodeposition of hydrogen from $0,1 \mathrm{~N}$ sulphuric acid under illumination on mercury, copper, nickel and silver electrodes and obtained a measurable photocurrent with light of wavelength as long as $4200 \AA$. The photoeffect in electrodeposition of oxygen on platinum, palladium, gold, silver and nickel was found to be of the same magnitude as in the case of hydrogen, and to follow the same laws. Hillson and Rideal conceived the photoeffect as influence of light on the kinetics of electrodeposition; this idea was disproved by later experimental results in this field.

Barker and Gardner 21 were the first who applied polarographic technique to investigation of photocurrents. They illuminated the electrode by a square-wave modulated 
Iight from a mercury are and recorded the photocurrent with a square-wave polarograph. In this way they obtained appreciable photocurrents in solutions of acids and in neutral solutions containing hydrogen peroxide or anions $\mathrm{NO}_{2}^{\prime}, \mathrm{NO}_{3}^{\prime}$ and $\mathrm{BrO}_{3}$. Unfortunately all the 4 latter species are photolytically decomposed by light of the wavelengths used which complicates the interpretation of results. Barker and Gardner assume on the basis of outer photoelectric effect, that under illumination electrons are emitted from the electrode into a distance of $50-100 \AA$ where their solvation occurs, and from where their subsequent diffusion back to the electrode takes place. The photocurrent appears only if some of the electrons are involved in a reaction in solution and fail to return to the electrode. For the photocurrent under these conditions the authors derived expression

$$
i_{p}=F \mathrm{Ce} \sqrt{\mathbf{k}_{A} C_{A} D_{e}}
$$

where $F$ is the Faraday constant, $C_{e}$ the concentration of solvated electrons in the average emission distance from the electrode, $\mathbf{k}_{\mathbf{A}}$ the rate constant of the electron capture reaction, $C_{A}$ the scavenger concentration and $D_{e}$ the diffusion coefficient of the solvated electron. The experimentally measured photocurrents were found to agree with the equation only at low concentration of scavengers.

In their photopolarographic experiments with flash technique Berg and Schweiss 22 observed in pure solutions of supporting electrolytes a kind of photocurrent which 
they called 23 the photoresidual current (Photoreststrom). This current is proportional to light intensity, increases with increasing negative potential and is especially high in acid solutions.

Heyrovský and Norrish 24 pointed to the relation between potentiometrically and polarographically studied photoeffects in solutions. They observed polarographic photocurrents in solutions of various acids and in presence of nitrous oxide, and suggested an interpretation based on photosebsitized dissociation of water.

Recently Delahay and Srinivasan 25 used the coulostatic method to study the photocurrents produced by flash irradiation in acid solutions on a mercury pool electrode. They discussed their results on the ground of Barier's theory and pointed out that especially the effect of electrode potential and of the double layer on photocurrent needed further clarification.

The Becquerel effect on pure metallic electrodes in transparent solutions is particularly attractive from both the photochemical and electrochemical point of view. It intimately concerns the mechanism of the elementary process of transfer of charge across an interface. However, the review of work hitherto done on this problem shows that the essential points pertaining to the nature of the effect still remain obscure. In principle there are two different concepts at present : the "physical" concept of Barker who interprets the photoeffect in solution as a special case of 
the classical photoelectric effect in vacuum, and a "chemical" concept formulated by Audubert who saw the origin of the photoeffect in a photochemical reaction in the interface electrode-solution. It is not impossible that both schemes are correct, each operating under different conditions.

The aim of the present thesis was to provide experimental data that would help to decide which concept is valid for the photoeffect in aqueous solutions. The name "electrochemical photoeffect" was introduced in order to specify the subject for which the term "Becquerel effect" is too general, and to underline its phenomenal analogy with the physical photoeffect. 


\section{Experimental}

For a correct account of the electrochemical photoeffect a simultaneous control of optical factors - the intensity and energy of light - and of electrical factors - the current and the electrode potential - appears essential. The work of the previous authors has shown the importance of a complete elimination of photochemical processes in solution. In order to simplify the interpretation of results a simple experimental technique was used. Since the purity of electrode surface is the first condition for obtaining reproducible results, mercury was chosen as the electrode material.

Bidistilled mercury was used for the mercury pool and dropping mercury electrodes.

Solutions were prepared from chemicals of "Anala R" grade and water redistilled from permanganate. Ethanol was purified by treatment with sulphuric acid, potassium hydroxide and silver nitrate according to Leighton and coworkers 26 , and its purity was controlled spectrophotometrically. Acetone was redistilled from permanganate。

The potentiometric measurements were carried out in parallel with two large quartz test-tubes connected by an electrolytic bridge to a common reference electrode. Mercury pool electrodes in the test-tubes were illuminated by a parallel beam of light from the mercury lamp. A stream of inert gas was constantly passed through or above the solution in the test-tubes. 
The cell for polarographic measurements (Fig.la), of circular cross-section with two planparallel waIls and of about $50 \mathrm{ml}$ volume, was made of quartz, with ground joints on four necks outlet parallel for inlet and of gas, inlet of solution, dropping electrode, thermometer and contact to the mercury pool (glass tube with sealed-in platinum wire and filled with mercury)。 To avoid liquid junction potentials and contamination of the solution by electrolyte from an electrolytic bridge, no separate reference electrode was used; a layer of mercury on the bottom of the cell served as counterelectrode. The cell was fixed by means of a special holder in a large water tank kept at $25.0 \pm 0.5^{\circ} \mathrm{C}$.

Throughout each experiment the solution was under a stream of nitrogen which had been purified from traces of oxygen by passing through two columns ( $35 \mathrm{~cm}$ Iong, $4 \mathrm{~cm}$ in diameter) containing amalgamated metaliic zinc in alkaline solution (about $2 \mathrm{M} \mathrm{KOH}$ ) saturated with anthraquinone- $\beta$-sodium sulphonate and one column of amalgamated zine in acid solution. (about $0.1 \mathrm{M} \mathrm{HCI}$ ) of chromous chloride. After the last column a washing bottle with suspension of silver oxide in $2 \mathrm{M} \mathrm{KOH}$ was placed to eliminate possible traces of HCI from the gas. Before entering the cell the nitrogen passed through a washing bottle containing the same solution as that in the cell. A11 parts of the glass apparatus were connected together by ground joints。

Nitrogen was bubbled through the solution first in the separate compartment (Fig。Ib), with stopcocks 1 and 2 opened 
Fig.l. Cell for polarographic measurements。 a - cell proper: I - thermometer, $\underline{2}$ - contact to the mercury pool, 3 - dropping mercury electrode, 4 - socket for part $\underline{b}$ - inlet of gas and solution, 5 - outlet of gas; b - compartment for deaeration of solution; function of stopcocks I, 2,3 described in text.

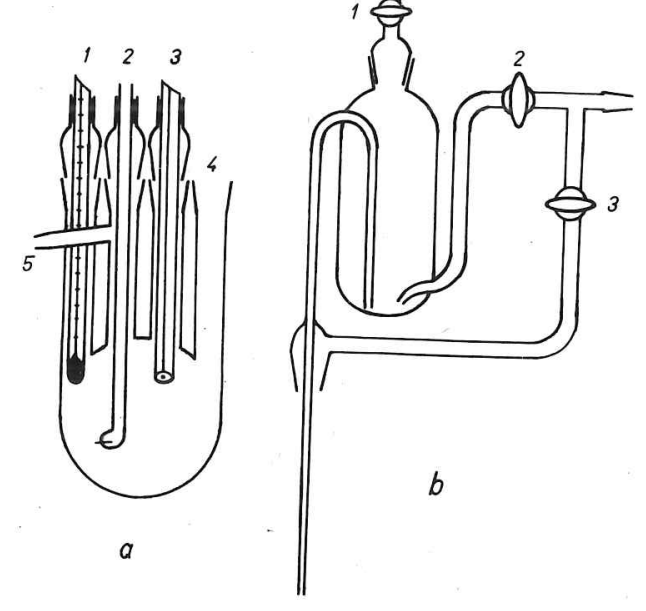

Fig.2. Circuit for polarographic current-time curves.

B - battery, $\underline{P}-$ po-

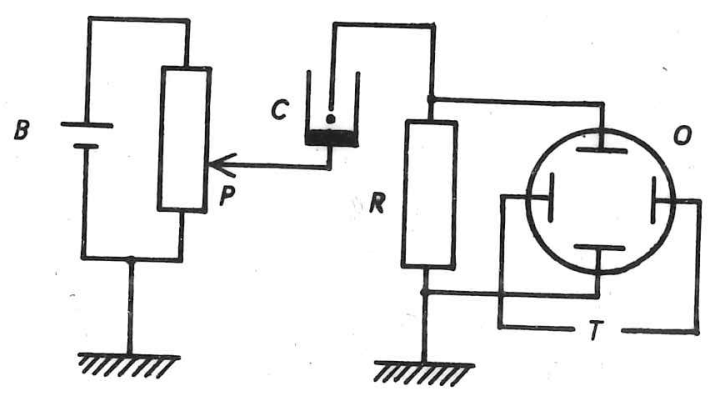
tentiometer, $\underline{C}-\operatorname{cell}$; $\underline{R}$ - measuring resistance, $\underline{0}$ - oscilloscope, $\underline{\text { I }}$ - time base (internal)。 
and 3 half closed at a high rate for at least $I$ hour before the solution was pressed over, by closing stopcocks 1 and 3 , into the nitrogen-filled cell with mercury on the bottom. During the actual measurements nitrogen was passed above the solution (stopcock 3 opened). The cell was designed expressediy to exclude passage of solution through any stopcock.

The capillary used for the dropping electrode was of the type introduced by smoler 27 for elimination of the transfer of electrolytic products on successive drops, with the lower end bent and cut at $45^{\circ}$. Its length was $20 \mathrm{~cm}$, inner diameter $60 \mu$, the rate of flow of mercury under constant height of mercury column $39 \mathrm{~cm}$ was $\mathrm{m}=0.529 \mathrm{~g} / \mathrm{sec}$ and drop-time in $0.1 \mathrm{II} \mathrm{KCl}$ at potential of zero charge $t_{1}=$ $=5.55 \mathrm{sec}$.

Light from a $1 \mathrm{~kW}$ high pressure mercury lamp type $\mathbb{N E} / \mathrm{D}$ was fopcused by means of a quartz lens through a quartz window in the side of the water tank and through a $8 \mathrm{~cm}$ layer of water to the cell on the tip of the capillary, so that when exposed each drop of mercury was growing in a strong field of light. The lamp and the tank were kept in a large metallic box with a fan for cooling on the top and with removable front side.

The emission of the lamp covered nearly homogeneouly the range of wavelengths from 2350 to $5400 \AA$ with a gap between 2540 and $2640 \AA$ and with two groups of lines at 5800 and $6100 \AA . A$ continuous control of constancy of the inten- 
sity of emission was provided by means of a cadmium photocell in circuit with a voltmeter. The drop of the voltmeter deflection was an indication that the lamp had to be changed for a new one.

For cutting off various portions of the spectrum from the short-wave side filter solutions were used in a quartz cell $2.5 \mathrm{~cm}$ thick. The filters and their absorption "edges" were following :

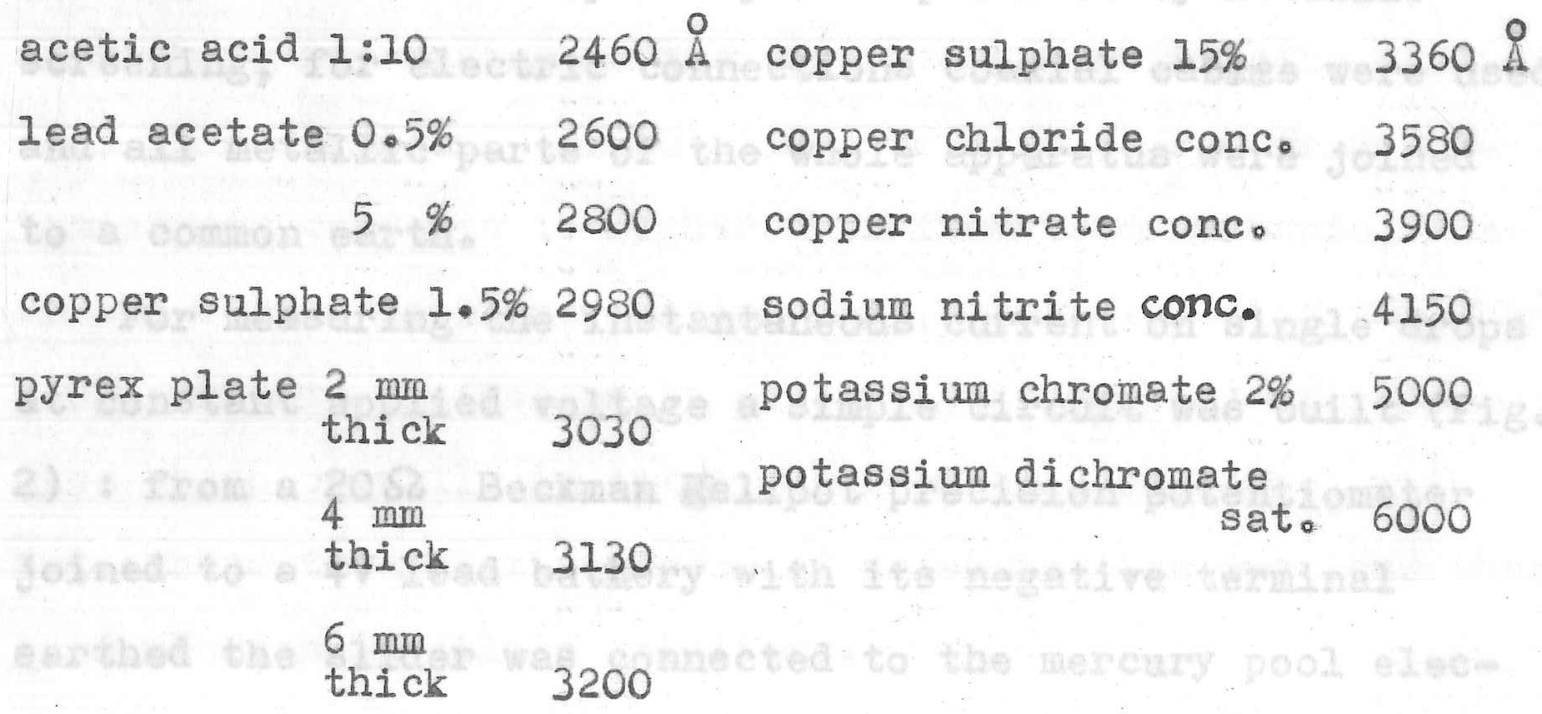

The emission of the lamp as well as the transmittance of the filters were measured and regularly checked by means of a small Hilger quartz spectrograph.

of each solution examined an absorption spectrum was recorded before the experiment on the Perkin-Elmer Model 137 or on Unicam S.P.800 UV Spectrophotometers. According to the absorbance suitable filters were chosen to ensure that the light illuminating the electrode was not absorbed by the solution. For reducing the intensity of light wire gawzes of various thickness were used the transmittance of which 
had been measured on the spectrophotometer.

In potentiometric measurements a slide resistance potentiometer and a spot galvanometer both made by Cambridge Instruments Co. were used. Polarographic curves were recorded by means of the Radiometer PO 4 Polariter.

In order to minimize the effect of stray fields on the measured currents, the reservoir of mercury and the tubing joining it with the capillary were provided by metallic screening, for electric connections coaxial cables were used, and all metallic parts of the whole apparatus were joined to a common earth.

For measuring the instantaneous current on single drops at constant applied voltage a simple circuit was built (Fig. 2) : from a $20 \Omega$ Beckman Helipot precision potentiometer joined to a $4 \mathrm{~V}$ lead battery with its negative terminal earthed the slider was connected to the mercury pool electrode and the dropping mercury electrode was joined to the earth across a $100 \mathrm{k} \Omega$ resistance. The voltage drop on the resistance as a measure of the current in the cell was followed on the screen of a Tektronix Type 531 A oscilloscope with maximal vertical sensitivity $1 \mathrm{mV}$ d.c. per cm. Since the currents observed never exceeded $0.3 \mu \mathrm{A}$, the maximal error in the applied voltage in this circuit was $30 \mathrm{mV}$ which represented the limits of precision in determining the red-limit potential of photocurrent (see Results). For exact evaluation the $i-t$ curves were photographed and the photographs magnified. 
The values of potentials were referred to the potential of zero charge in each solution. This potential can be easily found on the polarographic curve recorded at high sensitivity with minimal damping and especially when following the i-t curves: while potential of the dropping mercury electrode changes from positive to negative values, the amplitudes of oscillations due to the charging current decrease to zero when the potential of zero charge is reached and then start increasing in the opposite direction. The precision in determining the potential of zero charge from instantaneous currents is higher than from mean currents, since the former show the initial part, characteristic for charging current, unaffected by electrolytic current of impurities which prevails in later phase of the drop-time; with i-t curves the relative error of determination was less than $\pm 10 \mathrm{mV}$ even in dilute solutions.

The determination of the potential of zero charge was repeated before and after each measurement of the red-limit potential. Values of the voltage applied to the electrodes and indicating the zero charge and red-limit potentials were measured on the screen of the oscilloscope calibrated with a Weston element. It was found that the mercury pol as counterelectrode held its potential in all solutions fairly constant - this was apparently due to the low current-density maintained throughout all experiments; exceptionalIy a small drift was observed which never exceeded $30 \mathrm{mV}$. Since the dropping electrode was placed in the focus of 
converging beams of light, the photocurrent was affected by every slight change of the position of the capillary. For this reason exact comparative measurements of photocurrent could be carried out only when the capillary did not have to be moved - that is, only in measurements in one solution, like following the effect of wavelength, of light intensity or of gaseous substances。 This disadvantage was compensated by the high intensity of light on the electrode surface which produced high photocurrents. 


\section{Results}

A。 Potentiometric Measurements

Potentiometric measurements of the effect of UV light upon mercury pool electrodes in $0.1 \mathrm{M}$ aqueous solutions of $\mathrm{K}_{2} \mathrm{SO}_{4}$, $\mathrm{KOH}$ and $\mathrm{H}_{2} \mathrm{SO}_{4}$ have shown that in the atmosphere of hydrogen or nitrogen the potential of mercury begins to change towards negative values on illumination ( $F i g \circ 3$ ). In presence of oxygen the change of potential has positive direction (Fig.4). With full emission of the lamp the potential changes are of the order of millivolts per minute, whereas light of wavelengths above $3100 \AA$ produces a sheft of potential by several millivolts per hour only. Although the change of potential in the indicated direction was observed every time on illumination, its rate and its final limit were not sufficiently reproducible. In order to attain higher reproducibility instead of mercury pool the dropping mercury electrode was chosen which keeps its surface clean by constant renewing, and the effect was further studied by the polarographic method.

B. Polarographic Measurements

The dropping electrode was polarized in each solution within the limits of potentials where the electrolytic current does not exceed the magnitude of charging current. A current-voltage curve was recorded with a high sensitivity first in dark, then with electrode illuminated and then the 


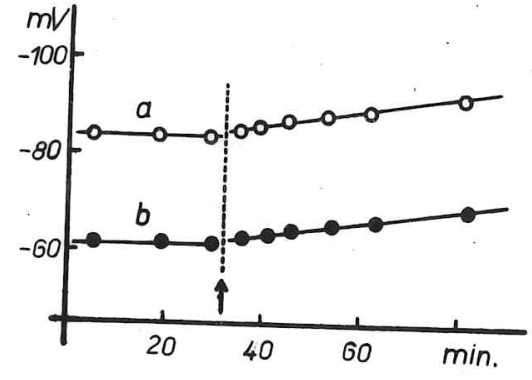

Fig.3. Change of potential of mercury pool electrodes in $\mathrm{O}_{0} \mathrm{IM} \mathrm{H}_{2} \mathrm{SO}_{4}$ on illumination. In pam rallel experiments soIution in atmosphere of :

a - nitrogen, $\underline{\mathrm{b}}$ - hydrogen. Beginning of exposure of electrodes to light denoted by arrow; full emission of lamp; potentials versus $0.1 M$ mercurous sulphate electrode.

Fig.4. Like in Fig.3 with the difference that under $\underline{b}$ the solution is in atmosphere of oxygen.

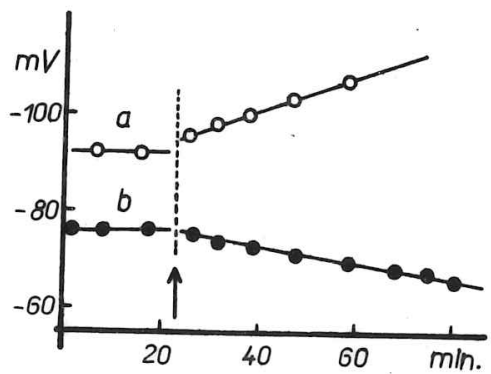


response of current to light passed through various filters was measured at constant potential.

Photocurrent, General Properties

It has been found that with sufficient light intensity in every solution there is a smaller or greater difference between the current on the dark and on the illuminated electrode. This difference, or the photocurrent, depends on the potential of the electrode, on the intensity and frequency of light, and on the composition of the solution. This is in general agreement with what was found under different conditions by Barker and Gardner 21 and by Berg and Schweiss ${ }^{22}$.

The Bowden's effect of light on the electrolytic evolution of hydrogen in conditions of polarographic electrolysis is shown on Fig. 5 for a 0.1 iv solution and on Fig 6 for a dilute solution of acid. From the polarographic curves it is evident that the Bowden's effect is not due to lowering of hydrogen overvoltage, but to a process independent of the electrode reaction of hydrogen ions. On Fig. 6 the entire reduction wave of hydrogen ions has been recorded; otherwise in the present work the photocurrent was measured as a rule only in that part of the polarographic curve where the electrolytic reaction does not practically come into force, i。e. in the region of residual current before the foot of the wave。

The mean photocurrent is independent of the height of 
Fig.5. Effect of illumination of dropping mercury electrode on polarographic curve of $0.1 \mathrm{ll}$. $\mathrm{H}_{2} \mathrm{SO}_{4}$ - a - dark curve, b- electrode illuminated by full light of lamp. Potentials versus mercury pool.
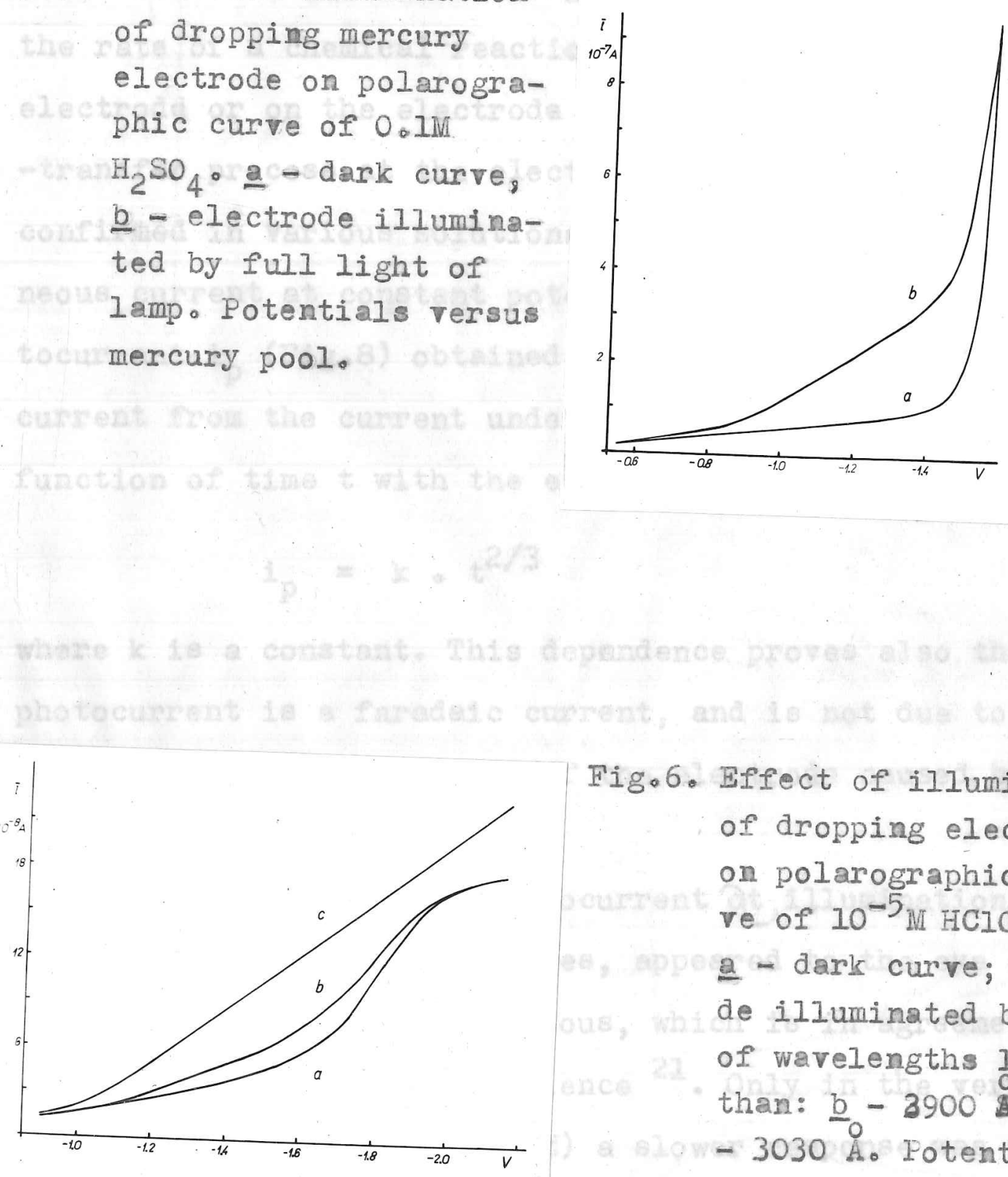

Fig.6. Effect of illumination of dropping electrode on polarographic curve of $10^{-5} \mathrm{M} \mathrm{HClO}_{4}$. a - darls curve; electrode illuminated by light of wavelengths longer than: $\underline{\mathrm{b}}-3900 \mathbb{\mathrm { E }}, \underline{\mathrm{c}}-$ - 3030 A. Potentials versus mercury pool. 
mercury column above the tip of the capillary (Fig.7)。 This indicates that the determining step in the photoprocess is the rate of a chemical reaction in the vicinity of the electrode or on the electrode surface or of an electron-transfer process at the electrode. This conclusion has been confirmed in various solutions by measuring the instantaneous current at constant potential. The instantaneous photocurrent $i_{p}($ Fig.8) obtained by substraction of the "dark" current from the current under illumination is a parabolic function of time $t$ with the exponent $2 / 3$ :

$$
i_{p}=k \cdot t^{2 / 3}
$$

where $k$ is a constant. This dependence proves also that the photocurrent is a faradaic current, and is not due to any eventual change of capacity of the electrode caused by ilIumination.

The time response of photocurrent at illumination, as could be observed on $i-t$ curves, appeared to the eye and on the photographs as instantaneous, which is in agreement with Barker's and Gardner's experience ${ }^{21}$. Only in the very diluted solutions $\left(10^{-5}-10^{-6} \mathrm{M}\right)$ a slower response was noticed. This can be explained by the fact that because of large resistance in the solution a sudden change of current $\Delta i$ causes a change of potential of the polarisable electrode $\Delta E$ by the $\Delta i \cdot R$ drop that can amount to some $0.1 \mathrm{~V}$ in our case. This change brings about an additional charging current $\Delta i_{c}$ according to the formula ${ }^{22}$ 


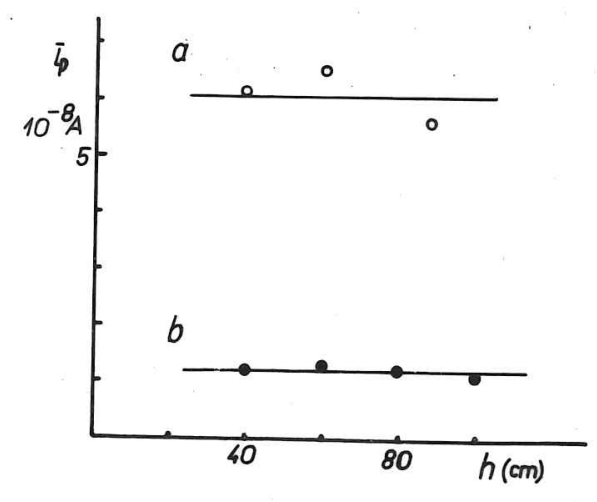

Fig.7. Dependence of mean photocurrent $\bar{i}_{p}$ on the height of mercury column h in solution of:

a - $0.1 \mathrm{Mi} \mathrm{NaHCO}$ at

$-1.75 \mathrm{~V}$ versus mercu-

ry pool (see Fig.25);

$\underline{b}-0.2 \mathrm{M}_{2} \mathrm{SO}_{4}$ at -1.0

$V$ versus mercury pool

(see Fig*5)。FulI

light of the lanp.

\section{Fig.8. Effect of illumination} of electrode on the instantaneous polerographic current. Solu-

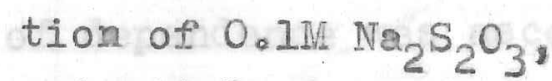
potential $-0.14 \mathrm{~V}$ versus point of zero charge. a - dark curve, b - dropping electrode illiminated by light of wavelengths longer than $3360 \AA$, c - instantaneous

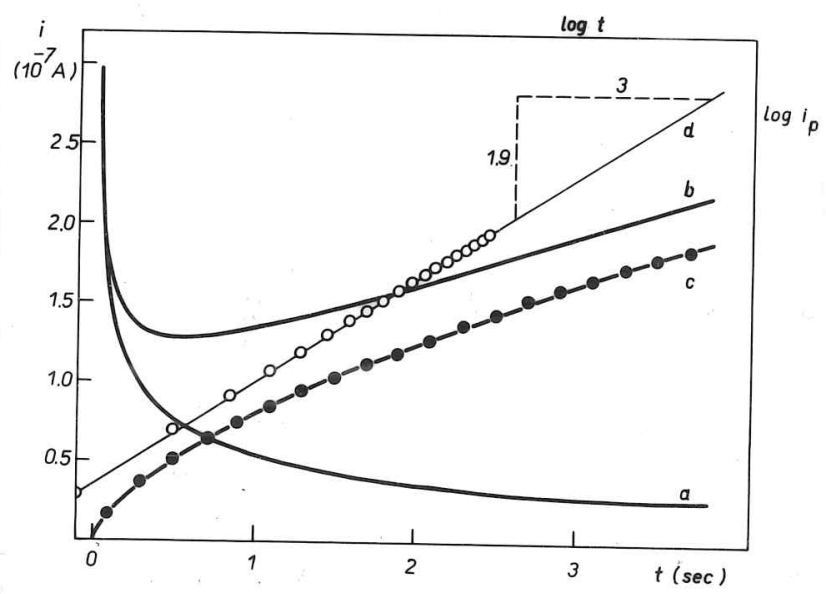
photocurrent ip obtained by substraction of a from $\underline{b}, \underline{d}$ - dependence of log $i_{p}$ on log to Circles correspond to full points on curve c. Slope of the straight line is $1.9: 3$. 


$$
\begin{gathered}
-25- \\
\Delta i_{C}=\frac{\Delta E}{R} \exp \left(-\frac{t}{R c_{D}}\right)
\end{gathered}
$$

where $R$ is the total resistance in the circuit and $C_{D}$ the double layer capacity (of the order of $10^{-6} \mathrm{~F}$ ). This additional current which adds to the basic current is the cause of the slow response; in dilute solutions it can practically last as long as a second.

The direct proportionality between the photocurrent and intensity of light reported by Price ${ }^{19}$, Hillson and Rideal 20 and Barker and Gardner. ${ }^{21}$ was found to hold in general (Fig・9)。

Price 19 has measured the increase of photocurrent with increasing electrode potential in solution of sulphuric acid and obtained an exponential dependence. The graph showing the logarithm of polarographic photocurrent in solution of sulphuric acid as a function of potential is on Fig.10; it can be very nearly approximated by two straight lines. This type of dependence was ascertained with all solutions where sufficiently high photocurrent could be produced (Fig.ll. and 12). The slopes and the proportions of the two linear parts of the dependence vary from one solution to another, and depend on the energy of the light used.

Dependence of Photocurrent on the Frequency of Iight According to Price 19 and Hillson and Rideal 20 the photocurrent in sulphuric acid is also an exponential funct- 
Fig.9. Dependence of photocurrent on light intensity。 a - 0.IM IiCl saturated with $\mathrm{CO}$, full light, $-1.0 \mathrm{~V}$ versus potential of zero charge; b - $0.1 \mathrm{M} \mathrm{H}_{2} \mathrm{SO}_{4}$ o full light, $-1.0 \mathrm{~V}$ versus potential of zero

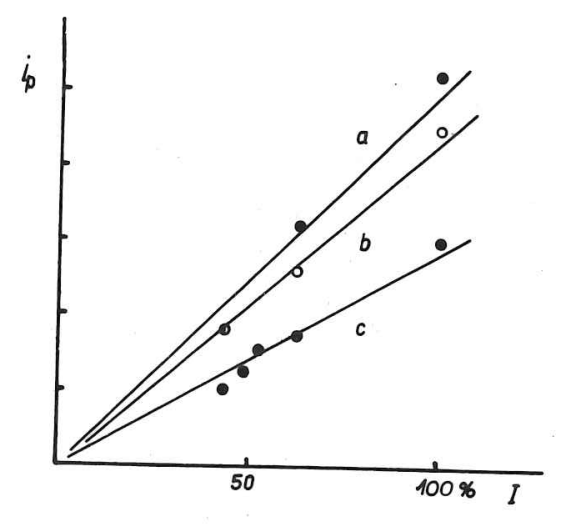
charge; $\subseteq-0 . I M \mathrm{Na}_{2}$ $\mathrm{S}_{2} \mathrm{O}_{3}+\mathrm{O} . \mathrm{IN} \mathrm{KCl}$, light of wavelengths longer than $3360 \AA,-0.27 \mathrm{~V}$ versus potential of zero charge. Values of current on arbitrary scale.

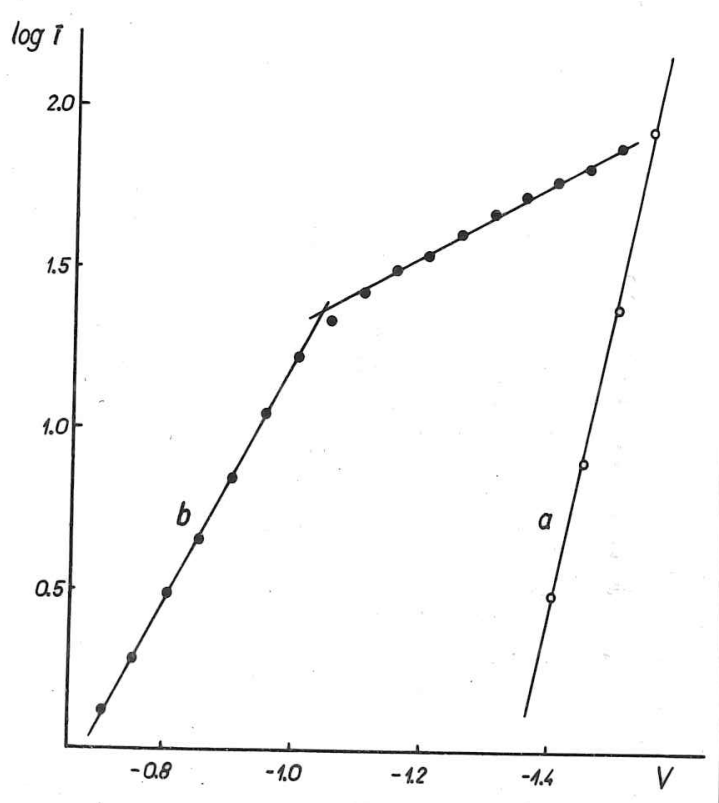

Fig.10. Dependence of logarithm of mean current on potential in $0 . \mathrm{IN} \mathrm{H}_{2} \mathrm{SO}_{4}$ (see Fig。 5). a - current of electrolytic deposition of hydrogen, b - photocurrent。 Unity of current scale $4 \cdot 10^{-9} \mathrm{~A}$; potentials versus mercury pool. 


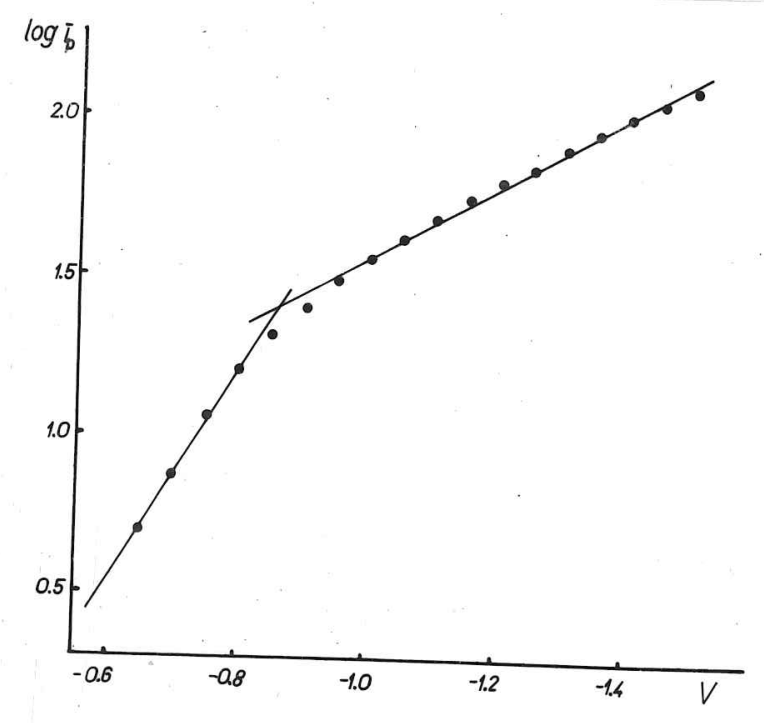

Fig.1I. Dependence of logarithm of mean photocurrent on potential in $10^{-5} \mathrm{M} \mathrm{KOH}$. Full light of the lamp; unity of current scale $8.10^{-10} \mathrm{~A}$; potentials versus mercury pool.

Fig.12. Dependence of Iogarithm of mean photocurrent on potential in $0.1 \mathrm{MN} \mathrm{Na} \mathrm{S}_{2} \mathrm{O}_{3}$. Light of wavelengths longer than 3030 ; unity of current scale $8.10^{-10} \mathrm{~A}$; potentials versus mercury pool.

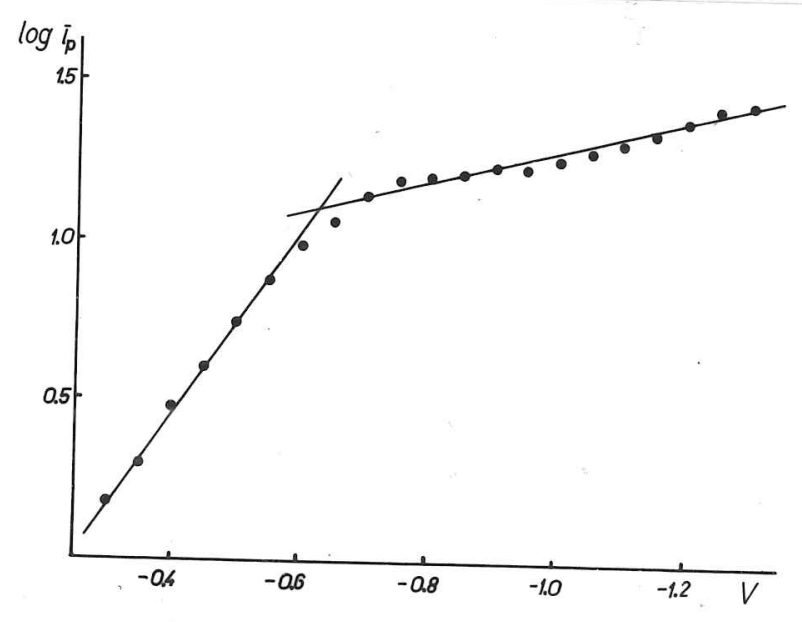


ion of the frequency of light. These authors were using monochromatic light for illumination of electrodes, and their result could not be verified in the present experimental arrangement with sufficient precision.

Let us accept that the photocurrent for monochromatic light at constant potential is given by the expression

$$
d i_{p}=\frac{I}{h \mu} \cdot k_{1} \cdot \exp \left(k_{2} \mu\right) d v
$$

where $I$ is the intensity and $\mathcal{w}$ the frequency of light, $h y$ is the energy of light and $k_{1}$ and $k_{2}$ are constants. Since

$$
I=h \mu \cdot c \cdot \rho,
$$

where $c$ is velocity of light and $\rho$ the density of radiation, we can write

$$
d i_{p}=c \cdot p \cdot k_{1} \exp \left(k_{2} \nu\right) d v
$$

For light composed of frequencies changing continuously from a constant low frequency $\boldsymbol{N}_{\mathrm{c}}$ to a higher frequency U the photocurrent will be given by the integral

$$
i_{p}=\int_{y_{c}}^{\mu} c \cdot \rho \cdot k_{1} \exp \left(k_{2} \psi\right) d j .
$$

If the density of radiation $\rho$ is constant, independent of frequency in the interval from $\mathcal{H}_{c}$ to $\mathcal{N}_{\text {, it follows }}$ for the photocurrent

$$
i_{p}=c \circ \rho \cdot \frac{k_{1}}{k_{2}} \exp \left[k_{2}\left(v-y_{c}\right)\right] \text {, }
$$


or in another form

$$
i_{p}=\frac{c \cdot \rho \cdot k_{1}}{k_{2} \exp \left(k_{2} \mathcal{\nu}_{c}\right)} \exp \left(k_{2} \boldsymbol{v}\right)
$$

where the first factor is a constant.

From the last formula it can be seen that with a light source emitting a continuous band the photocurrent is an exponential function of thelshort-wave limit, provided the number of photons per $\mathrm{cm}^{3}$ is equal for each energy within the band.

We may try to apply equation (4) on results of our measurements since the experimental arrangement roughly fulfils its conditions. The spectrum of the high pressure mercury lamp between the wavelengths 2700 and $5500 \AA$ can be considered as approximately continuous with uniform emission. The ratio of photocurrents recorded with electrode illuminated by varfous portions of spectrum of the lamp should be an exponential function of the difference of short-wave end frequencies, as requires equation (4). Fig.13 shows the current- voltage curves for 0.IM sulphuric acid with electrode illuminated through various filters. From the ratio of photocurrents and from the corresponding short-wave end frequencies the value of the constant

$$
k_{2}=\frac{\ln _{\frac{i}{i} 1}^{\frac{1}{i} 2}}{v_{1}-\nu_{2}}
$$


has been calculated; for the cu $\mathrm{cm}$, for $\mathrm{c}$ and $\mathrm{d}, \mathrm{k}_{2} \mathrm{c}=3.05 \mathrm{x}$ $=3.15 \times 10^{-4} \mathrm{~cm}$. This result $\mathrm{p}$. of equation (4) to the results obtai. perimental arrangement is justified。

Potential - Red Limit Diagrams

The experimentally found dependence of photocurrent on frequency of light and on electrode potential can be put in an empirical equation :

$$
i_{p}=k_{a} \cdot \exp \left(k_{b} \cdot h v\right) \cdot \exp \left[-k_{c}\left(\mathbb{E}-E_{R}\right)\right]
$$

where $E_{R}$ is a reference potential and $k_{a}, k_{b}$ and $k_{c}$ are constants provided the density of radiation is constant over the given range of wavelengths。

From this equation it is evident that a certain value of photocurrent can be reached either at a constant electrode potential by increasing the energy of light, or, with light of constant wavelength, by increasing the electrode potential. For a fixed value of photocurrent a linear relation results between the electrode potential and the energy of light producing the photocurrent:

$$
h \nu=\frac{I}{k_{b}} \ln \frac{i_{p}}{k_{a}}+\frac{k_{c}}{k_{b}}\left(E-E_{R}\right)
$$

If the linear relation (6) holds for monochromatic light, it should be also applicable, in view of eq.(4), to continuous spectrum with short-wave limit energy hy. In order 
has been calculated; for the curves $b$ and $c, k_{2} c=3.10 \times 10^{-4}$ $\mathrm{cm}$, for $\mathrm{c}$ and $\mathrm{d}, \mathrm{k}_{2} \mathrm{c}=3.05 \times 10^{-4} \mathrm{~cm}$ and for $\mathrm{b}$ and $\mathrm{d} \mathrm{k}_{2}=$ $=3.15 \times 10^{-4} \mathrm{~cm}$. This result proves that the application of equation (4) to the results obtained with the present experimental arrangement is justified.

\section{Potential - Red Limit Diagrams}

The experimentally found dependence of photocurrent on frequency of light and on electrode potential can be put in an empirical equation :

$$
i_{p}=k_{a} \cdot \exp \left(k_{b} \cdot h v\right) \cdot \exp \left[-k_{c}\left(E-E_{R}\right)\right]
$$

where $E_{R}$ is a reference potential and $k_{a}, k_{b}$ and $k_{c}$ are constants provided the density of radiation is constant over the given range of wavelengths。

From this equation it is evident that a certain value of photocurrent can be reached either at a constant electrode potential by increasing the energy of light, or, with light of constant wavelength, by increasing the electrode potential. For a fixed value of photocurrent a linear relation results between the electrode potential and the energy of light producing the photocurrent :

$$
h \nu=\frac{I}{k_{b}} \ln \frac{i_{p}}{k_{a}}+\frac{k_{c}}{k_{b}}\left(E-E_{R}\right)
$$

If the linear relation (6) holds for monochromatic light, it should be also applicable, in view of eq.(4), to continuous spectrum with short-wave limit energy hy. In order 
to verify this conclusion it is convenient to choose for the constant value of photocurrent its limit, i。e. its smallest measurable value, and to determine the "red-limit potentials" with light passed through various filters. By "red-limit potential" the potential is understood at which the photocurrent begins to appear under given illumination. Iikewise, for a given potential light of a definite red-limit wavelength exists with which the photocurrent can just be observed.

The limit of photocurrent necessarily depends on the experimental arrangement used, on the intensity of light and on the sensitivity of the current-measuring instrument. Its value in our case was $10^{-9} \mathrm{~A}$, corresponding to a deflection of $1 \mathrm{~mm}$ on the screen of the oscilloscope with full sensitivity. The potential of reference $\mathbb{E}_{\mathbb{R}}$ was, for the mentioned practical reasons, in each solution the corresponding potential of zero charge. The "red-limit potentials" when plotted against the values of energy of the shortest wavelength transmitted by the filters showed a linear dependence in all solutions examined (Fig.14 and following).

The linear relation between the two variables determining the red-limit of photocurrent is a useful characterization of the electrochemical photoeffect. The intercept of the straight line on the energy axis at potential of zero charge gives the minimal quantum necessary for production of photocurrent in absence of electric field due to ionic double layer, whereas the slope of the line indicates to what extent the photoprocess depends on the potential of the electrode. 


$$
-32-
$$

Fig.13. Current-voltage curves of $\mathrm{O}_{0} \mathrm{IM} \mathrm{H} \mathrm{H}_{2} \mathrm{SO}_{4}$ with electrode illuminated through various filters. a - full light of the lamp; b - light through c-through $15 \% \mathrm{CusO}_{4}^{\text {Pyrex; }}$ filter; d- light through $\mathrm{NaNO}_{2} ; \underline{e}-$ - dark curve. Potentials versus mercury pool.

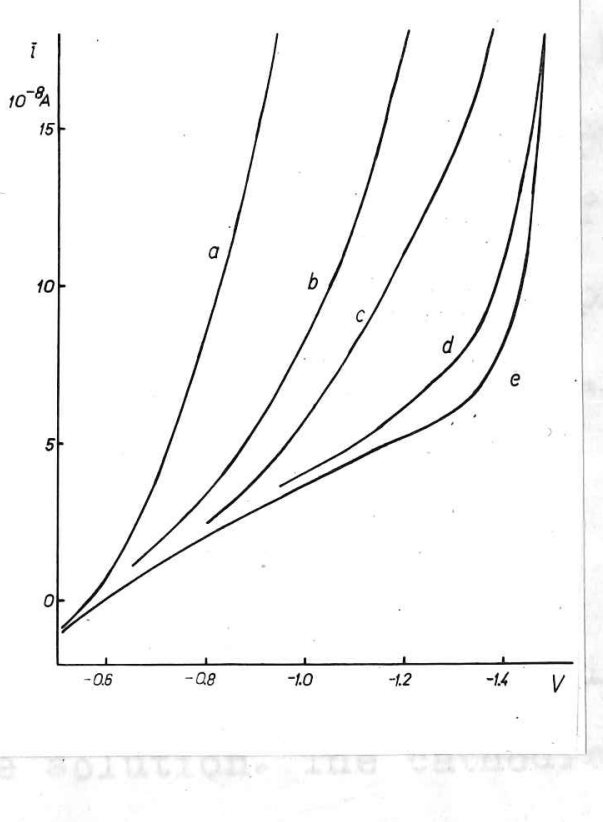

Fig.14. Potential-red limit

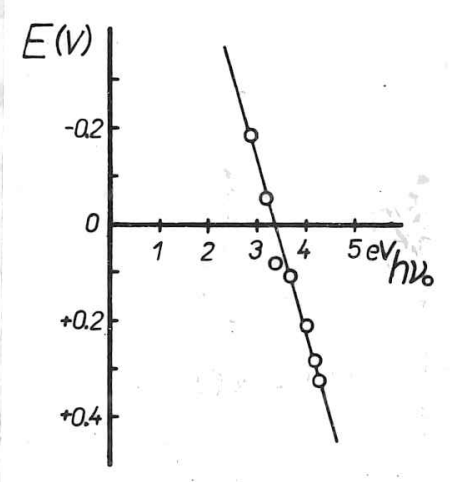
diagram. Relation between potential of the electrode and energy of red limit of photocurrent. $0.1 \mathrm{M} \mathrm{HClO}$, potentials versus point of zero charge. 
The straight line on the "potential-red limit diagrams" represents for each solution a border on the energy - potential plane under which no photocurrent can be obtained in the given experimental conditions. All the values of potential or energy of light exceeding this border line produce photocurrent, the further from the line, the higher.

Cathodic Photocurrent in Indifferent Electrolytes

The direction and magnitude of photocurrent varies according to the composition of the solution. The cathodic photocurrent, of the direction of electrons entering into the solution from the electrode, is in aqueous solutions a general phenomenon, and shall be dealt with first.

In neutral and alkaline aqueous $0.1 \mathrm{~W}$ solutions containing cations of alkali or alkaline earth metals and anions like halides, hydroxide, chlorate, perchlorate, azide, cyanate, sulphite, sulphate, phosphate, acetate and benzoate the photocurrent is cathodic, approximately of equal magnitude - rather small, with the intercept on the potential red limit diagram between 4.1 and $4.5 \mathrm{eV}$ and the slopes of the straight lines between 0.9 and $1.4 \mathrm{eV} / \mathrm{V}$ (Fig.15). A finer distinction between the above solutions, as far as the effects of cations or anions on the photocurrent are concerned, has not been studied. The reproducibility in determination of the intercept with one solution, each time freshIy prepared, was within $\pm 0.1 \mathrm{eV}$. 


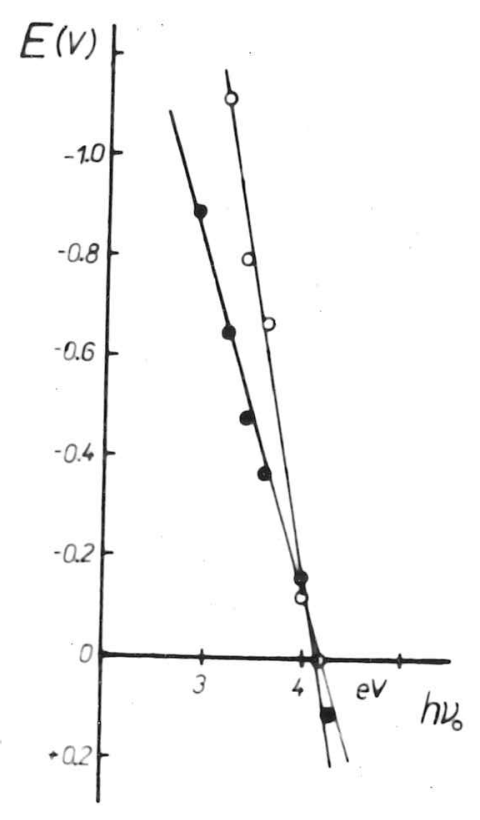

Fig.15. Potential-red limit diagrams of $0.1 \mathrm{M}$ solutions of sodium tetraborate (circles) and acetate ( $f u l l$ points). Potentials versus point of zero charge.

Fig.16. Effect of dilution on the mean photocurrent. Solutions of: @ - IiCl, b- $\mathrm{CaCl}_{2}$; concentrati ions: $-10^{-1} \mathrm{M}_{2} \leq-$ $-10^{-3} \mathbb{M}, 2_{2}-10^{-5} \mathbb{M}_{0}$ Full light of the lamp, potentials versus point of zero charge.

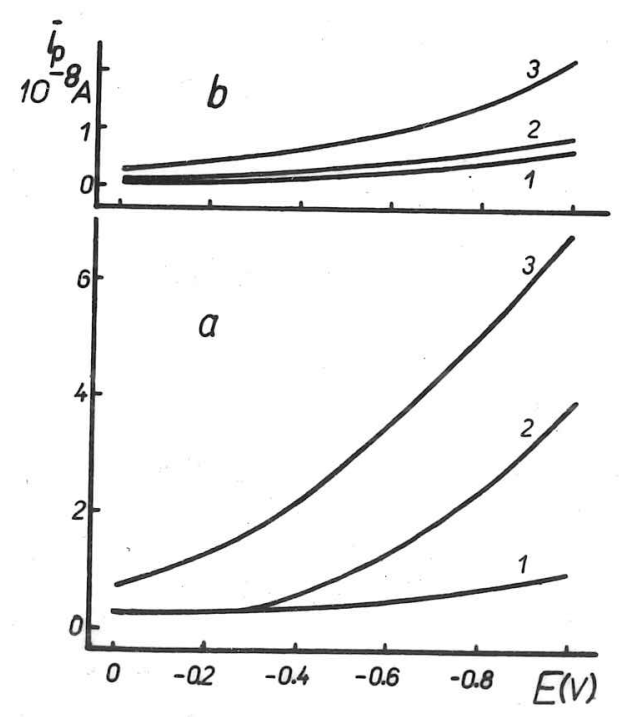


On Fig.6 it can be seen $t$ tration of acid the photocur rographic reduction wave 0 with this effect a markec ved on dilution of electrolytic 16). The magnitude of photocurrent dep. the charge of cations present in the solution of salts of alkaline earth metals have to be more $t_{12}$ red times more diluted than the solutions of salts of alka. metals to give photocurrent of the same magnitude. This difference is evident also on the potential-red limit diagrams (Fig.17): on dilution both the intercept and the slope of the straight line are changed. With monovalent cations on $10^{4}$ fold dilution the intercept decreases by about $0.5 \mathrm{eV}$ whereas with divalent cations the decrease is only about $0.1 \mathrm{eV}$. Solution of lanthanum acetate did not give any increase of photocurrent even on $10^{4}$ fold dilution.

In purely ethanolic solutions the photocurrent is in general by more than one order less than in aqueous solutions. On Fig.18 are compared the potential-red limit diagrams of O.IM and ethanolic solutions. It is evident that for producing photocurrent in ethanolic solutions more negative potentials must be applied to the electrode than in aqueous solutions. The effect of dilution on photocurrent appears in ethanol like in water with the difference that in water the slopes of the straight lines of the diluted and concentrated solutions with increasing negative potential diverge, where- 
On Fig.6 it can be seen that in solution of low concentration of acid the photocurrent increases beyond the polarographic reduction wave of hydrogen ions. In accordance with this effect a marked increase of photocurrent was observed on dilution of electrolytic solutions in general (Fig. 16). The magnitude of photocurrent depends here strongly on the charge of cations present in the solution. The solutions of salts of alkaline earth metals have to be more than hundred times more diluted than the solutions of salts of alkali metals to give photocurrent of the same magnitude. This difference is evident also on the potential-red limit diagrams (Fig.17): on dilution both the intercept and the slope of the straight line are changed. With monovalent cations on $10^{4}$ fold dilution the intercept decreases by about $0.5 \mathrm{eV}$ whereas with divalent cations the decrease is only about $0.1 \mathrm{eV}$. SoIution of Ianthanum acetate did not give any increase of photocurrent even on $10^{4}$ fold dilution.

In purely ethanolic solutions the photocurrent is in general by more than one order less than in aqueous solutions. On Fig.18 are compared the potential-red linit diagrams of $0.1 M$ and ethanolic solutions. It is evident that for producing photocurrent in ethanolic solutions more negative potentials must be applied to the electrode than in aqueous solutions. The effect of dilution on photocurrent appears in ethanol like in water with the difference that in water the slopes of the straight lines of the diluted and concentrated solutions with increasing negative potential diverge, where- 
Fig.17. Effect of dilution on potential-red limit diagram. Solutions of: 2- $\mathrm{IiCl}_{1} \underline{\mathrm{b}}-\mathrm{CaCl}_{2}$; concentrations: 1 - $10^{-1} \mathbb{M}, \quad 2 ;-10^{-5_{M}}$ Potentials versus point of zero charge.
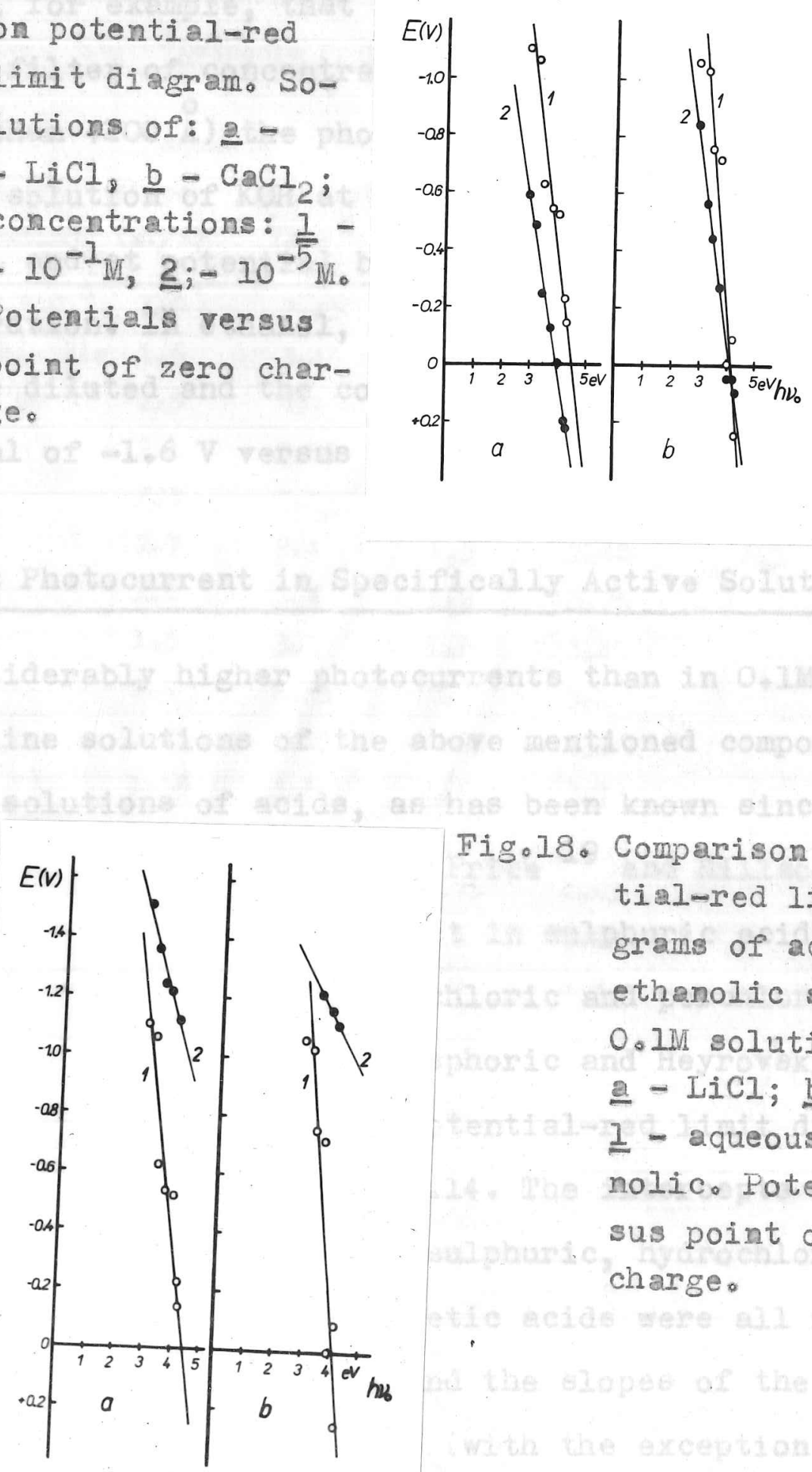

Fig.18. Comparison of potential-red limit diagrams of aqeuous and ethanolic solutions. $0.1 M$ solutions of : a - $\mathrm{LiCl} ; \underline{\mathrm{b}}-\mathrm{CaCl}_{2}$; $\underline{I}$ - aqueous, $\underline{\underline{2}}$ - ethanolic. Potentials versus point of zero charge. 
as in ethanol they converge (Fig.19). From Fig.19 it can be seen, for example, that on the electrode illuminated through filter of concentrated $\mathrm{NaNO}_{2}$ (i。e. by wavelengths longer than $4200 \AA$ A) the photocurrent begins to appear in aqueous solution of $\mathrm{KOH}$ at potential $-0.6 \mathrm{~V}$ at $10^{-5} \mathrm{M}$ concentration, and at potential by $0.6 \mathrm{~V}$ more negative at $0.1 \mathrm{VI}$ concentration. In ethanol, on the other hand, it appears in both the diluted and the concentrated solutions at the same potential of $-1.6 \mathrm{~V}$ versus point of zero charge.

\section{Cathodic Photocurrent in Specifically Active Solutions}

Considerably higher photocurrents than in $0.1 \mathrm{~N}$ neutral or alkaline solutions of the above mentioned compounds appear in solutions of acids, as has been known since the Bowden's discovery. Bowden ${ }^{18}$, Price 19 and Hillson and Rideal $2 \hat{0}$ were studying the effect in sulphuric acid, Barker and Gardner 21 used also hydrochloric and perchloric acids, Berg and Schweiss 22 added phosphoric and Heyrovsky and Norrish ${ }^{24}$ acetic acids. The potential-red limit diagram of $0.1 M$ perchloric acid is on Fig.14. The intercepts on the potential-red limit diagrams of sulphuric, hydrochloric, perchloric, oxalic, citric and acetic acids were all found to lie between 3.25 and $3.50 \mathrm{eV}$ and the slopes of the straight Iines between 2.4 and $2.8 \mathrm{eV} / \mathrm{V}$ (with the exception of oxalic acid where the slope is $4.2 \mathrm{eV} / \mathrm{V})$ - see Tab.l. 
T a b 1 e 1

Parametars of Straight Lines from Potential-Red Limit Diagrams for

\section{Cathodic Photocurrent}

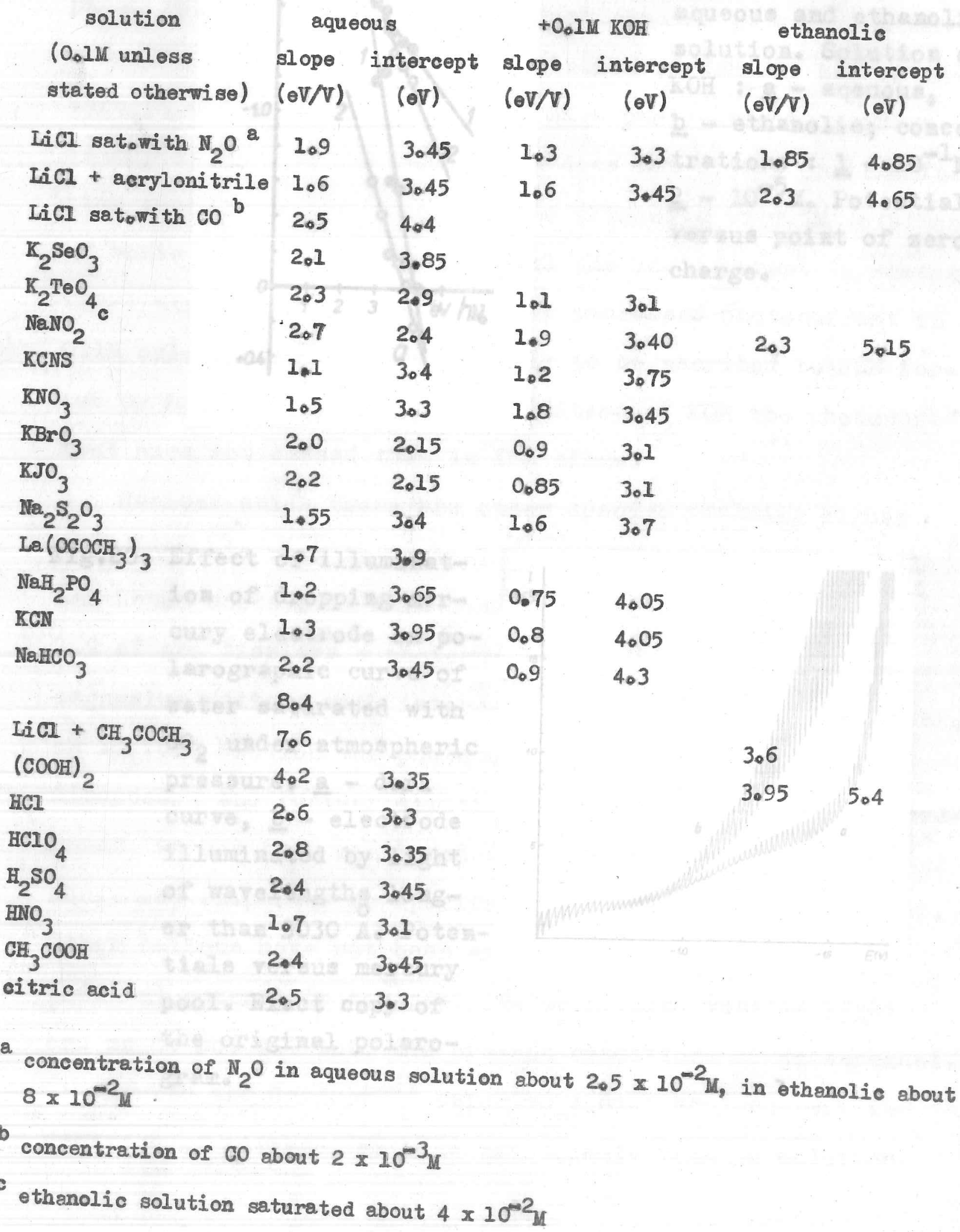




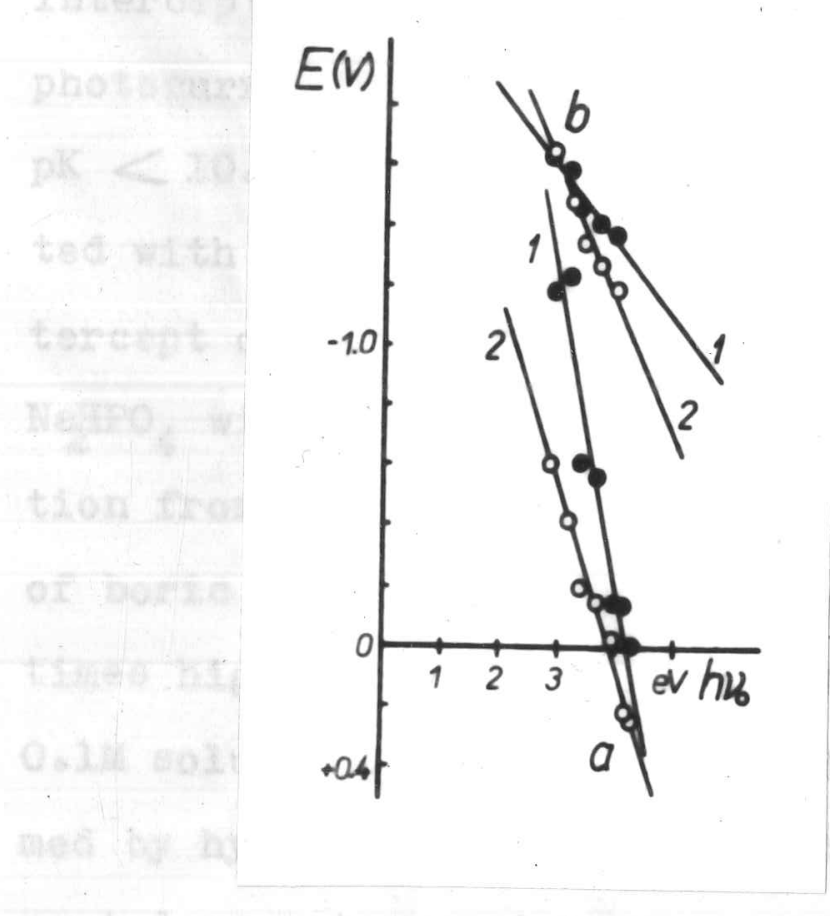

Fig.19. Comparison of the effect of dilution on photocurrent in aqueous and ethanolic solution. Solution of $\mathrm{KOH}$ : a - aqeuous, $\underline{b}$ - ethanolic; concentrations : $1-10^{-1} \mathrm{M}$; $\underline{2}-10^{-5} M_{0}$ Potentials versus point of zero charge .

Fig.20. Effect of illumination of dropping mercury electrode on polarographic curve of water saturated with $\mathrm{CO}_{2}$ under atmospheric pressure. a-dark curve, $\underline{b}$ - electrode illuminated by light of wavelengths longer than 3030 A. Potentials versus mercury

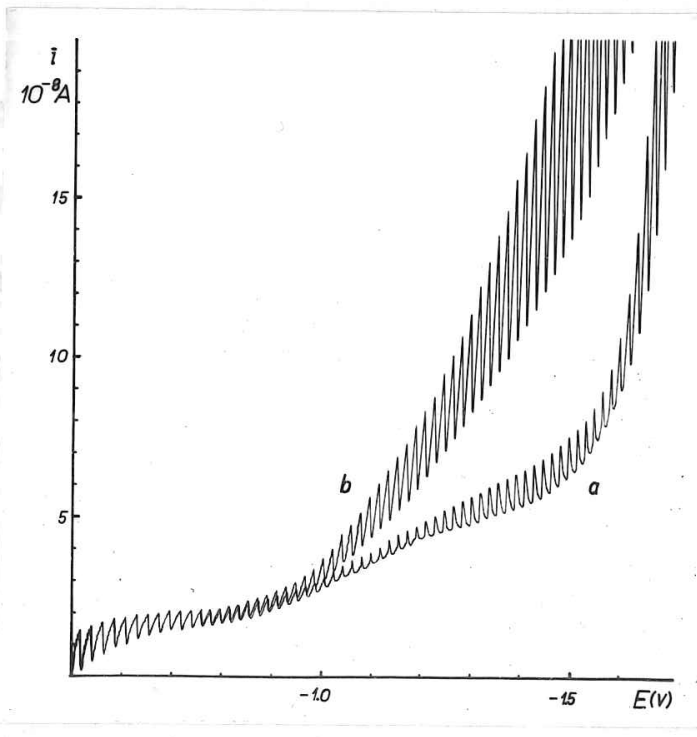
pool. Exact copy of the original polarogram. 
Weaker acids yield smaller photocurrents and higher intercepts on the potential - red limit diagrams; enhanced photocurrents were observed in solutions of acids with $\mathrm{pK}<10$. Considerable photocurrent appears in water saturated with $\mathrm{CO}_{2}(\mathrm{Fig} \cdot 20)$. A $0.1 \mathrm{Ml}$ solution of $\mathrm{NaH}_{2} \mathrm{PO}_{4}$ has an intercept of $3.65 \mathrm{eV}$ and yields a high photocurrent, whereas $\mathrm{Na}_{2} \mathrm{HPO}_{4}$ with intercept of $4.05 \mathrm{eV}$ does not differ on illumination from other neutral solutions (Fig.2I). In O.IM solutions of boric acid, glycine and phenol the photocurrent is several times higher than in $0.1 \mathrm{MCl}$. An increased photocurrent in O. IN solution of KCN has probably to be ascribed to HCN formed by hydrolysis since after addition of KOH the photocurrent does not exceed that in $\mathrm{KOH}$ alone.

Besides acids there are other species yielding higher photocurrents when in neutral or alkaline solutions (Tab.I). Lanthanum acetate in $0 . I M$ concentration has an intercept of $3.9 \mathrm{eV}$ and displays a photocurrent noticeably higher than magnesium acetate with intercept of $4.4 \mathrm{eV}\left(F_{i g} \cdot 22\right)$; however, on 10 fold dlution the photocurrent due to lanthanum ions disappears and further dilution does not lead to its reappearance, as has been mentioned above. In solutions of zinc and manganese sulphates no specific photocurrents were observed. Other cations have not been examined as they either are reduced at potentials too positive or absorb visible light and so do not fit into the present conditions of measurement. Barker and Gardner ${ }^{21}$ reported a high photocurrent in presence of nitrate, nitrite and bromate ions in solution. 
Fig.21. Comparison of potential-red limit diagrams of solutions of different acidity. O.IM solution of $I-\mathrm{NaH}_{2} \mathrm{PO}_{4} ; \underline{\underline{2}}-$

- $\mathrm{Na}_{2} \mathrm{HPO}_{4} \cdot$ Potentials versus point of zero charge.

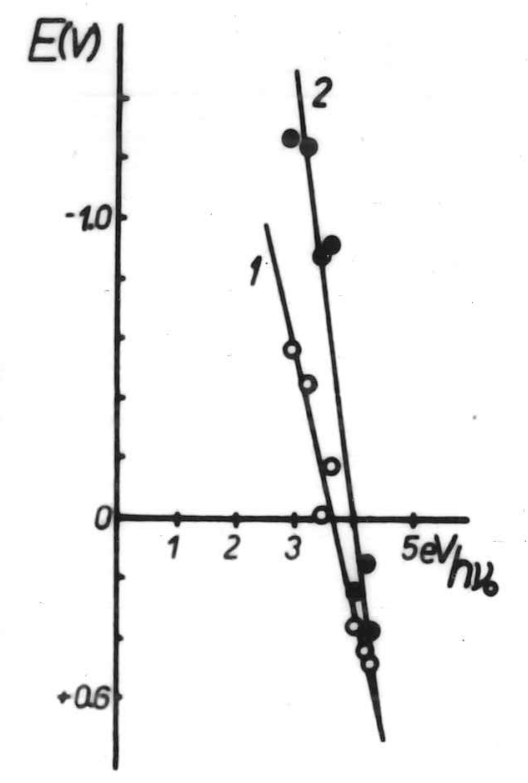

Fig.22。 Potential-red limit di-

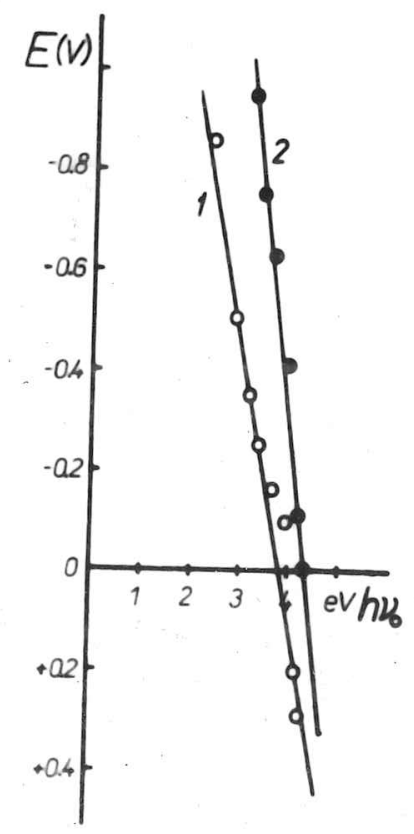
agrams of $0.1 \mathrm{M}$ acetates of: 1 - Ianthanum, 2 - magnesium. Potentials versus point of zero charge. 
This has been confirmed in present experiments, and few more active anions were found : iodate, thiocyanate thiosulphate, selenite and tellurate. Heyrovsky and Norrish ${ }^{24}$ noticed a strong photoeffect in solutions of nitrous oxide $\mathrm{N}_{2} \mathrm{O}$; equally effective is acrylonitrile.

The photocurrent in aqueous solution of $\mathrm{IiCl}$ saturated with carbon monoxide under atmospheric pressure (about $10^{-3} \mathbb{N}$ ) increases notably with increasing negative potential; on the potential-red limit diagram there is hardy any change of the value of the intercept of $\mathrm{IICl}$ solution noticeable, but the slope of the straight line changes to $2.5 \mathrm{eV} / \mathrm{V}$ from 1.4 $\mathrm{eV} / \mathrm{V}$ in.pure $0.1 \mathrm{M}$ IICI (Fig.23)。

When the electrode is illuminated in aqueous solutions of bicarbonate or acetone, on the current-voltage curve there appears a shape of a polarographic "wave" (Fig.24) caused by a.steep increase of photocurrent from zero at relatively negative potentials. The straight lines on the potential-red limit diagrams have in both cases an unusually high slape $(7.6 \mathrm{eV} / \mathrm{V}$ acetone, $11.4 \mathrm{eV} / \mathrm{V}$ bicarbonate) which indicates a strongdependence of the photoprocess on electrode potential (Fig.25, 33). In bicarbonate solutions a cathodic photocurrent appears already at positive potentials, but disappears when the potential of zero charge is reached and does not reappear intil at about $-1 \mathrm{~V}$ versus potential of zero charge. The intercept extrapolated for the photocurrent on the positive side is $3.3 \mathrm{eV}$ (Fig.25). The increase of photocurrent in solution of acetone occurs at potentials so nega- 


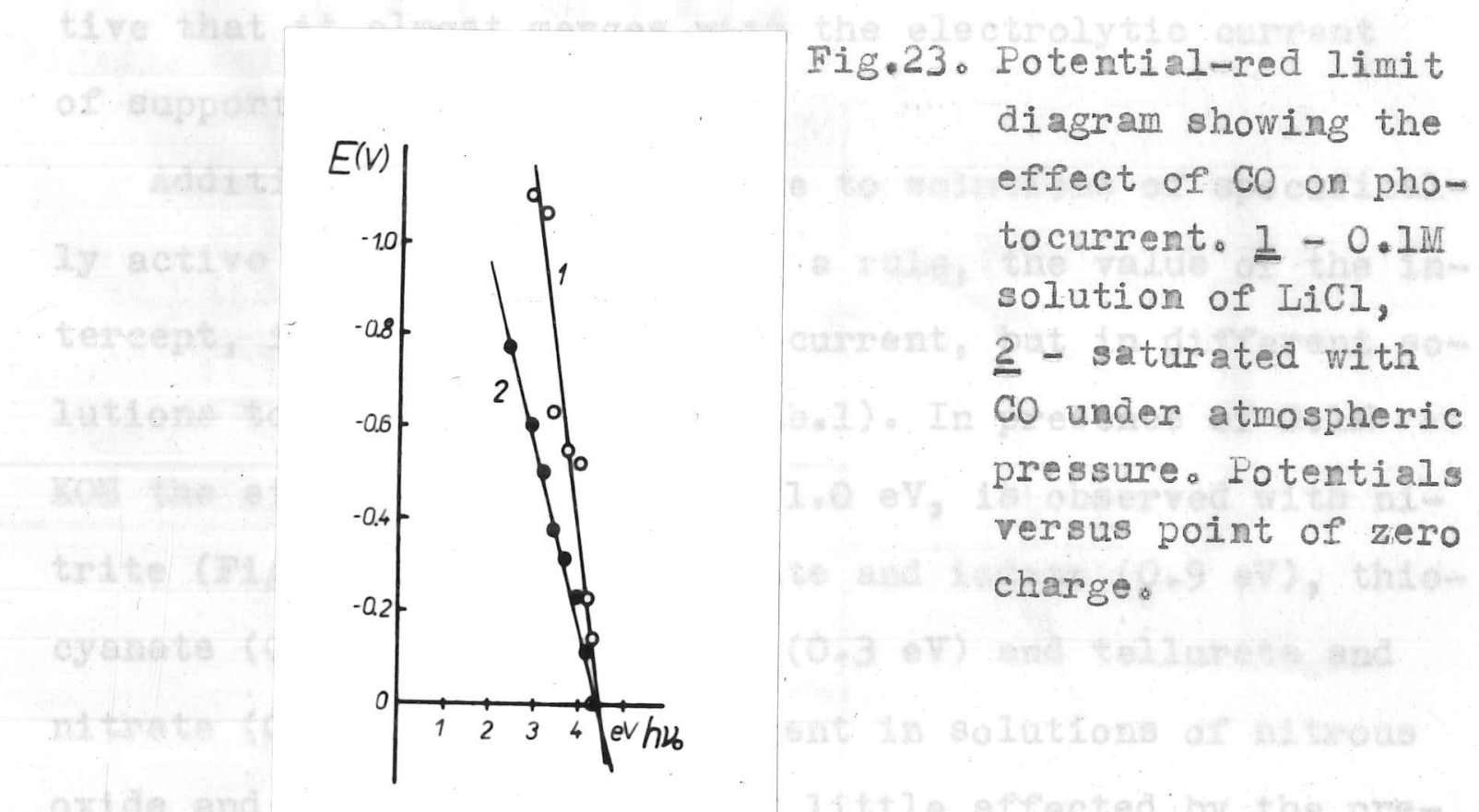

Fig.24. Effect of 11 lumination of the dropping electrode on polarographic curve of bicarbonate solution. $0.1 \mathrm{M}$ $\mathrm{NaHCO}_{3}$, potentials versus mercury pool.

a - dark curve, b- electrode illuminated by full light of the lamp.

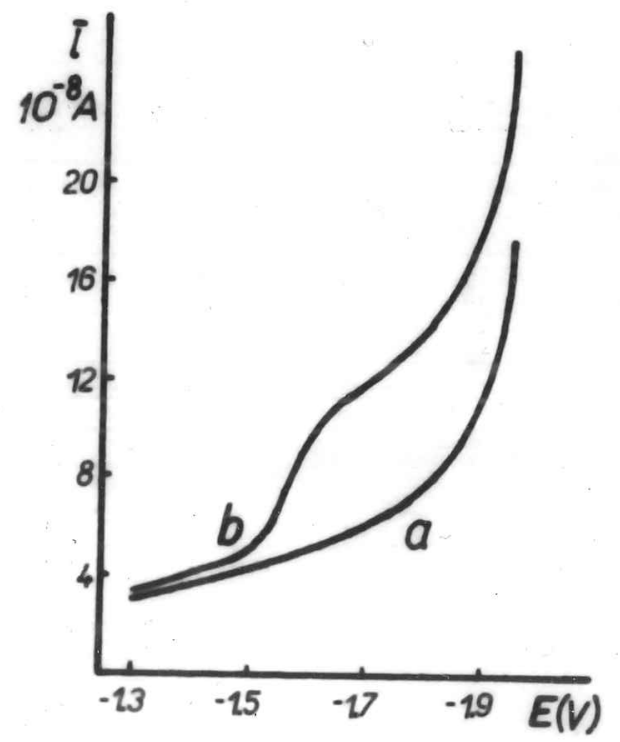


tive that it almost merges with the electrolytic current of supporting electrolyte.

Addition of alkali hydroxide to solutions of specificalIy active species increases, as a rule, the value of the intercept, i.e. reduces the photocurrent, but in different soIutions to different extent $(\mathrm{Tab} \cdot \mathrm{I})$. In presence of $0.1 \mathrm{M}$ $\mathrm{KOH}$ the strongest increase, by $1.0 \mathrm{eV}$, is observed with nitrite (Fig.26), then with bromate and iodate $(0.9 \mathrm{eV})$, thiocyanate $(0.4 \mathrm{eV})$, thiosulphate $(0.3 \mathrm{eV})$ and tellurate and nitrate $(0.2 \mathrm{eV})$. The photocurrent in solutions of nitrous oxide and acrylonitrile is very little affected by the presence of $\mathrm{OH}^{-}$ions; on the intercept no change is observable (Fig.28, 31). The addition of an indifferent electrolyte to the specifically active solutions up to $0.1 \mathrm{M}$ concentration has no effect on the value of the intercept (Fig.27), and neither any effect of valency of the cation was observed $(F i g \circ 28)$.

In alkaline solutions of substances giving high photocurrent the effect of pyridine can be followed. Pyridine is known 28 to form in alkaline media at the surface of mercury an adsorbed layer which desorbs at negative potentials. It was found that pyridine suppresses the photocurrent to a certain extent in the whole potential range, but that the discontinuous increase of charging current resulting from a sudden disappearance of the adsorbed layer is accompanied by a simultaneous discontinuous increase of the photocurrent $(F i g \circ 29)$. 
Fig.25. Fotential-red limit diagrams of $\mathrm{O}$.IM solutions of $\mathrm{NaHCO}_{3}$ (circles) and $\mathrm{Na}_{2} \mathrm{CO}_{3}$ (full points)。Potentials versus point of zero charge.

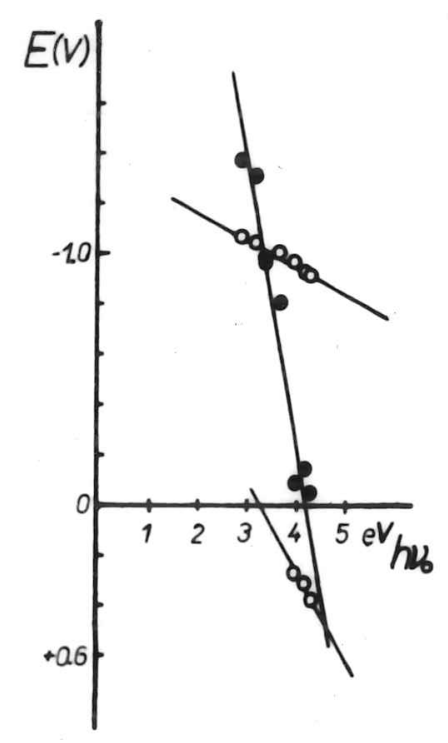

Fig.26. Effect of hydroxyl

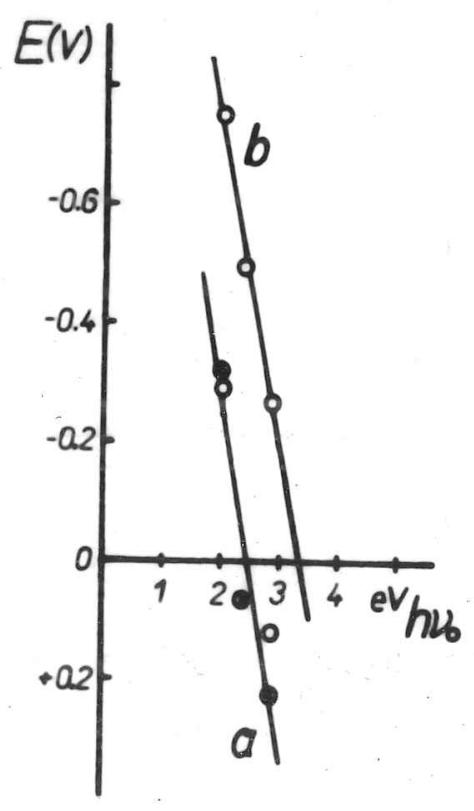
ions on potential-red limit diagram of $\mathrm{NaNO}_{2}$ solution. a - circles - $0.1 \mathrm{IIIN} \mathrm{NaNO}_{2}$, full points - 0.IN $\mathrm{NaNO}_{2}+$ $+0.1 \mathrm{MCl}$; $\underline{\mathrm{b}}-0.1 \mathrm{M}+$ + 0.IM KOH. Potentials versus point of zero charge. 


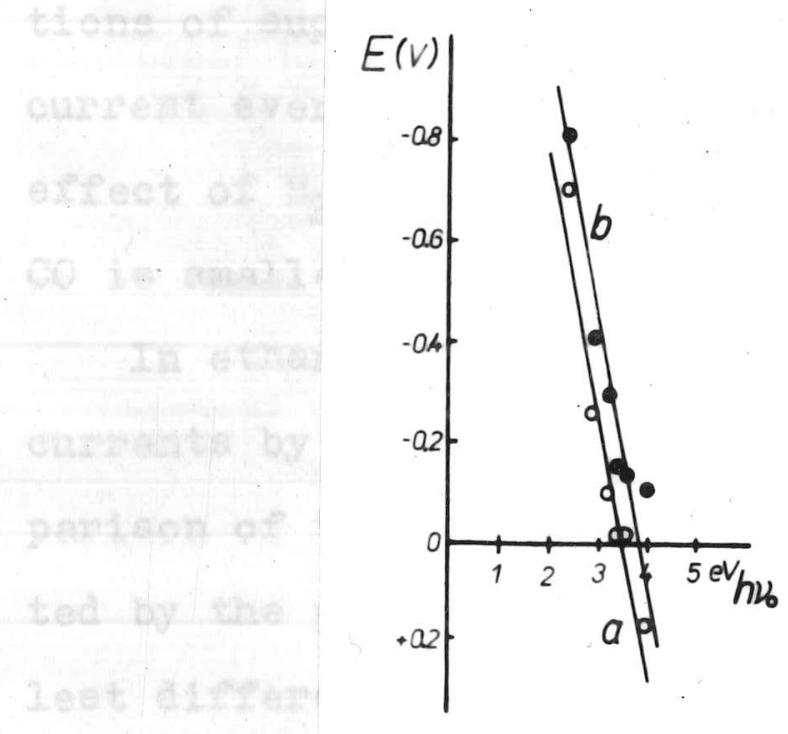

Fig.27. Effect of $\mathrm{KCl}$ and $\mathrm{KOH}$ on the potential-red limit diagram of $\mathrm{Na}_{2} \mathrm{~S}_{2} \mathrm{O}_{3}$ solution. a - $0.1 \mathrm{M} \mathrm{Na} \mathrm{Na}_{2} \mathrm{O}_{3}+$ $+0.1 \mathrm{M} \mathrm{KCl} ; \underline{\mathrm{b}}-0.1 \mathrm{M}$ $\mathrm{Na}_{2} \mathrm{~S}_{2} \mathrm{O}_{3}+0.1 \mathrm{MINO}$ Potentials versus point of zero charge.

Fig.28. Potential-red limit diagram of nitrous oxide solutions. Circles - 0. $1 \mathrm{MI} \mathrm{BaCl}_{2}$, fuIl points - O.IM $\mathrm{KOH}$, saturated with $\mathrm{N}_{2} \mathrm{O}$ under atmospheric pressure. Potentials versus point of zero charge.

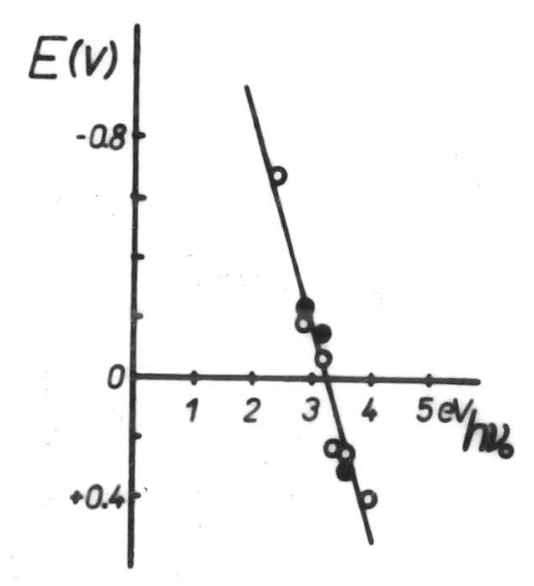


The compounds yielding high photocurrents in O.IN solutions of supporting electrolytes cause an increase of photocurrent even in highly diluted solutions. Fig。30 shows the effect of $\mathrm{N}_{2} \mathrm{O}$ on photocurrent in $10^{-6} \mathrm{M} \mathrm{KCl}$; the effect of Co is smaller, but still pronounced。

In ethanol the specifically active species produce photocurrents by more than one order less than in water. The comparison of the effects of the two solvents is well demonstrated by the potential-red limit diagrams (Table 1)。 The smallest difference between the intercepts in water and in ethanol, $1.2 \mathrm{eV}$, was found in solutions of acrylonitrile (Fig。 31). Nitrous oxide with intercept in water of $3.45 \mathrm{ev}$, the same as acrylonitrile, has the intercept in ethanolic solution slightly higher, $4.85 \mathrm{eV}$ (Fig.32). However, in both cases the straight lines in the two media remain nearly parallel. A considerable difference between the slopes in the two solvents can be observed in solutions of acetone (Fig.33).

Anodic Photocurrent

All the photocurrents described above were cathodic, i。e. of the direction of electrons going from the electrode into the solution. Anodic photocurrent, of the opposite direction, was found in acid, neutral or alkaline solutions of oxalate, dimethyloxalate, malate, tartrate, pyruvate, citrate, glycollate, lactate, chloro-acetate, glycine, diacetyl and glyoxal (Fig.34). It does not appear with any of the previously mentioned inorganic compounds, or with formate, acetate, fuma- 
Fig.29. Mean photocurrent in presence of pyridine. a $=0.1 \mathrm{M} \mathrm{KCNS}+0.1 \mathrm{M}$ pyriaine; $\underline{b}-0.1 \mathrm{MI} \mathrm{Na}_{2}$ $\mathrm{S}_{2} \mathrm{O}_{3}+0.1 \mathrm{~N}$ pyridine. Potentials versus point of zero charge; light of wavelengths longer than 3030 .
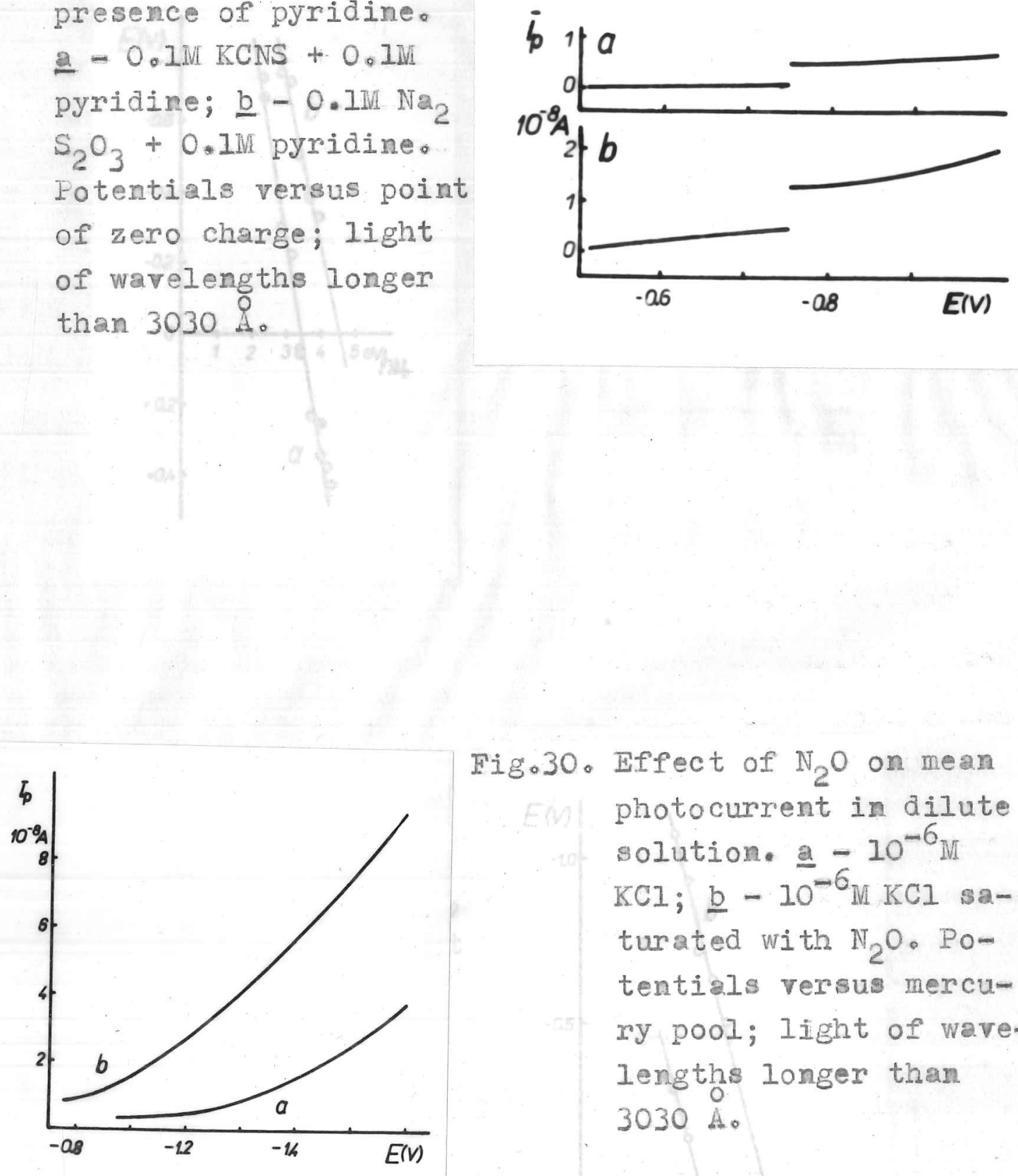

Fig.30. Effect of $\mathrm{N}_{2} \mathrm{O}$ on mean photocurrent in dilute solution. a $-10^{-6} \mathrm{M}$ $\mathrm{KCI} ; \underline{\mathrm{b}}-10^{-6} \mathrm{M} \mathrm{KCI}$ saturated with $\mathrm{N}_{2} \mathrm{O}$. POtentials versus mercury pool; light of wavelengths longer than 3030 A。 


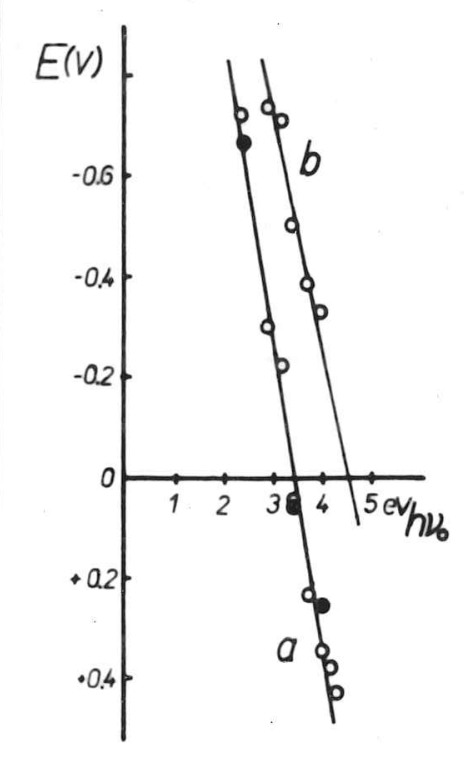

Fig.31. Potential-red limit diagram of $0 . I N$ acrylonitrile in: a $-0.1 \mathrm{M}$ aqueous LiCl (circles) or $\mathrm{KOH}$ ( $\mathrm{fuIl}$ points); $\underline{b}-0.1 \mathrm{M}$ ethanolic IiCl. Potentials versus point of zero charge,

Fig.32. Potential-red limit diagram of nitrous oxide in $0.1 \mathrm{~N}$ IiCl in: a - water, $\underline{b}$ - ehtanol, Potentials versus point of zero charge.

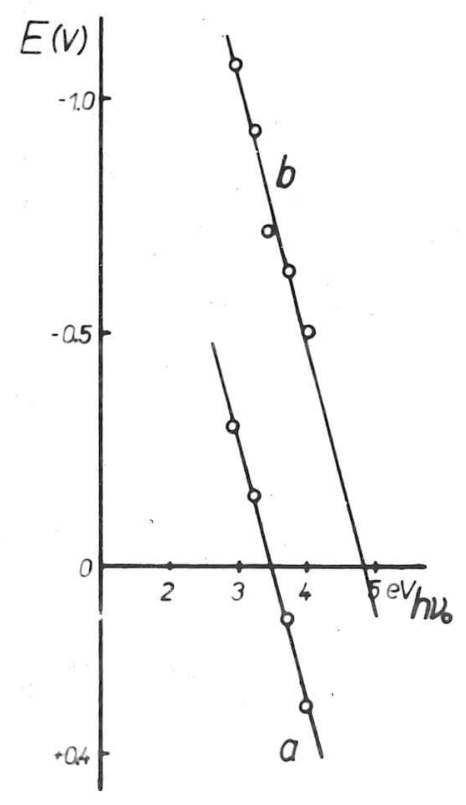


Fig.33. Potential-red limit diagram of acetone. O.IM IiCl in: a - water, c - ethanol; + 0.1M acetone in $\underline{b}$ - water, d -ethanol. Potentials versus point of zero charge.

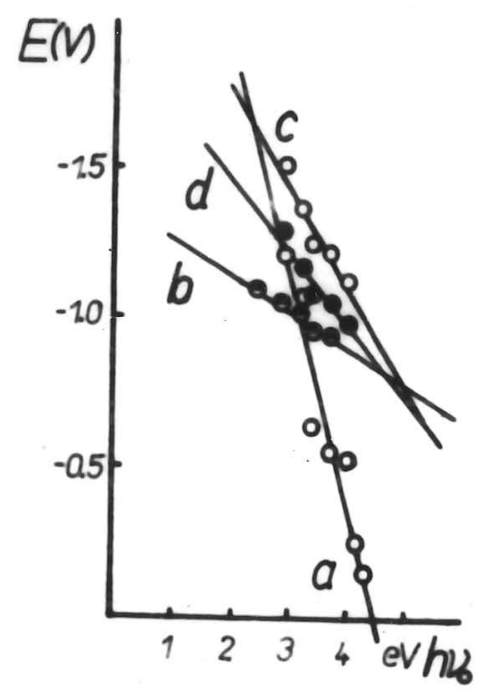

Fig.34. Anodic photocurrent.

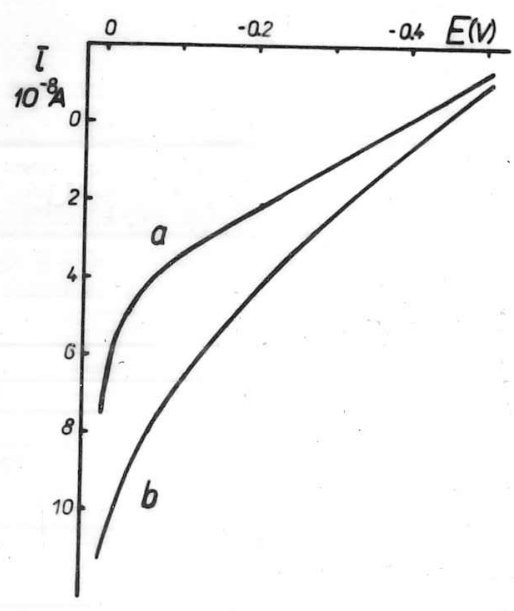
Polarographic curve of 0.IN Na-tartrate: a - in dark, $\underline{b}$ - electrode illuminated by light of wavelengths longer than $3030 \AA$. Potentials versus mercury pool. 
rate or maleate, acrylonitrile, acetophenone, acetaldehyde or acetone. Non-occurrence of the anodic photocurrent in solutions of ethyleneglykole, ethylenediamine or ethylenediomine-tetraacetic acid is an indication that the effect is not connected with anodic dissolution of mercury.

The anodic photocurrent like the cathodic, but with opposite sign, increases exponentially with potential. The dependence of the logarithm of photocurrent on potential can also be approximated by two linear parts (Fig.35). The relation between the potential and energy of the red limit of anodic photocurrent is also linear (Fig.36, Table 2). Unlike the cam thodic photocurrent the anodic photocurrent is of the same magnitude in aqueous and ethanolic solutions (Fig.37)。

On the potential-red limit diagrams the intercepts of solutions of acids are higher than those of their salts (Table 2); an addition of alkaline hydroxide to the salts has no effect (Fig.38). The straight line on the diagram of oxalate ends at low potentials by a short section independent of light energy (Fig.36). A similar case was observed with malic, lactic and Cl-acetic acids (Fig.39) and in dilute solutions of oxalic acid (Fig.40)。 
T a b I e 2

Parameters of Straight Lines from Potential-Red Iimit

Diagrams for Anodic Photocurrent

solution

(0.1Ii)

oxalic acid aq.

ethan.

$\mathrm{Na}$ oxalate

dime thy foxalate

tartaric acid

$\mathrm{Na}$ tartrate

Cl-acetic acid

glycine

glycollic acid

lactic acid

malic acid

citric acid slope

$(\mathrm{eV} / \mathrm{V})$

3.2

4.0

3.8

3.6

3.2

4.2

2.8

$4 \cdot 2$

2.2

2.2

2.6

2.5 intercept

$(\mathrm{eV})$

4.9

4.8

3.9

5.4

5.0

4.4

5.5

6.0

4.5

4.5

5.0

5.0 


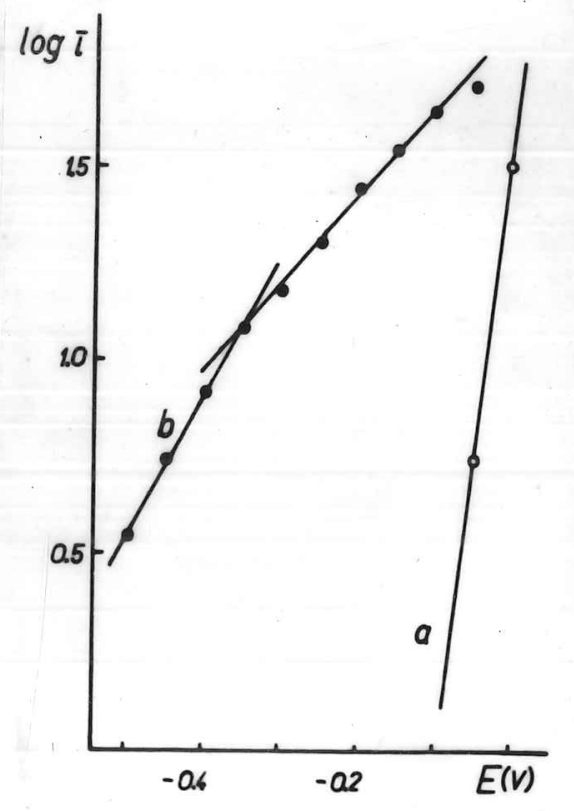

Fig.35. Dependence of logarithm of mean current on potential in 0.IM Na-Aartrate (see Fig.34)。

a - current of electrolytic dissolution of mercury, $\underline{\mathrm{b}}$ - photocurrent. Unity of current scale $8.10^{-10} \mathrm{~A}$; potentials versus mercury pool.

Fig.36. Potential-red limit diagrams of anodic photocurrents in some solutions: a -0.1 M Na-tartrate, $\underline{b}-0.1$ II tartaric acid, $\underline{c}-$ - 0.IN dimethyl oxalate, d-0.IN glycine. Potentials versus point of zero charge.

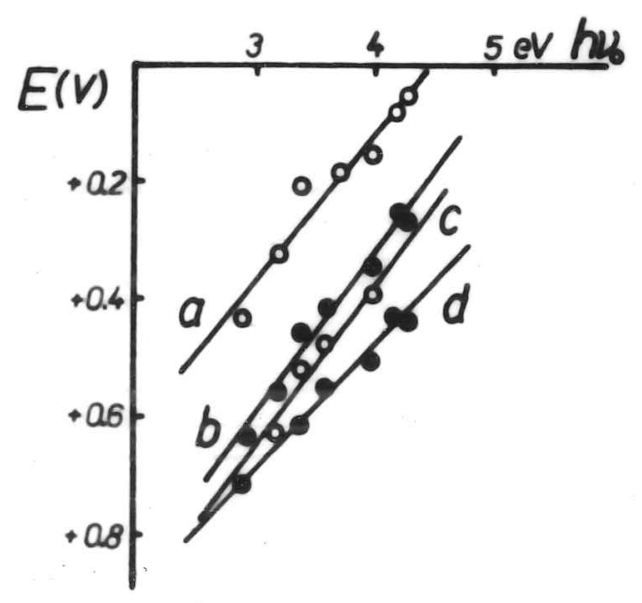


Fig.37. Potential-red limit diagram of anodic photocurrent in $0.1 \mathrm{~N}$ solution of oxalic acid in: a - water, $\underline{b}$ - ethanol. Potentials versus point of zer charge.
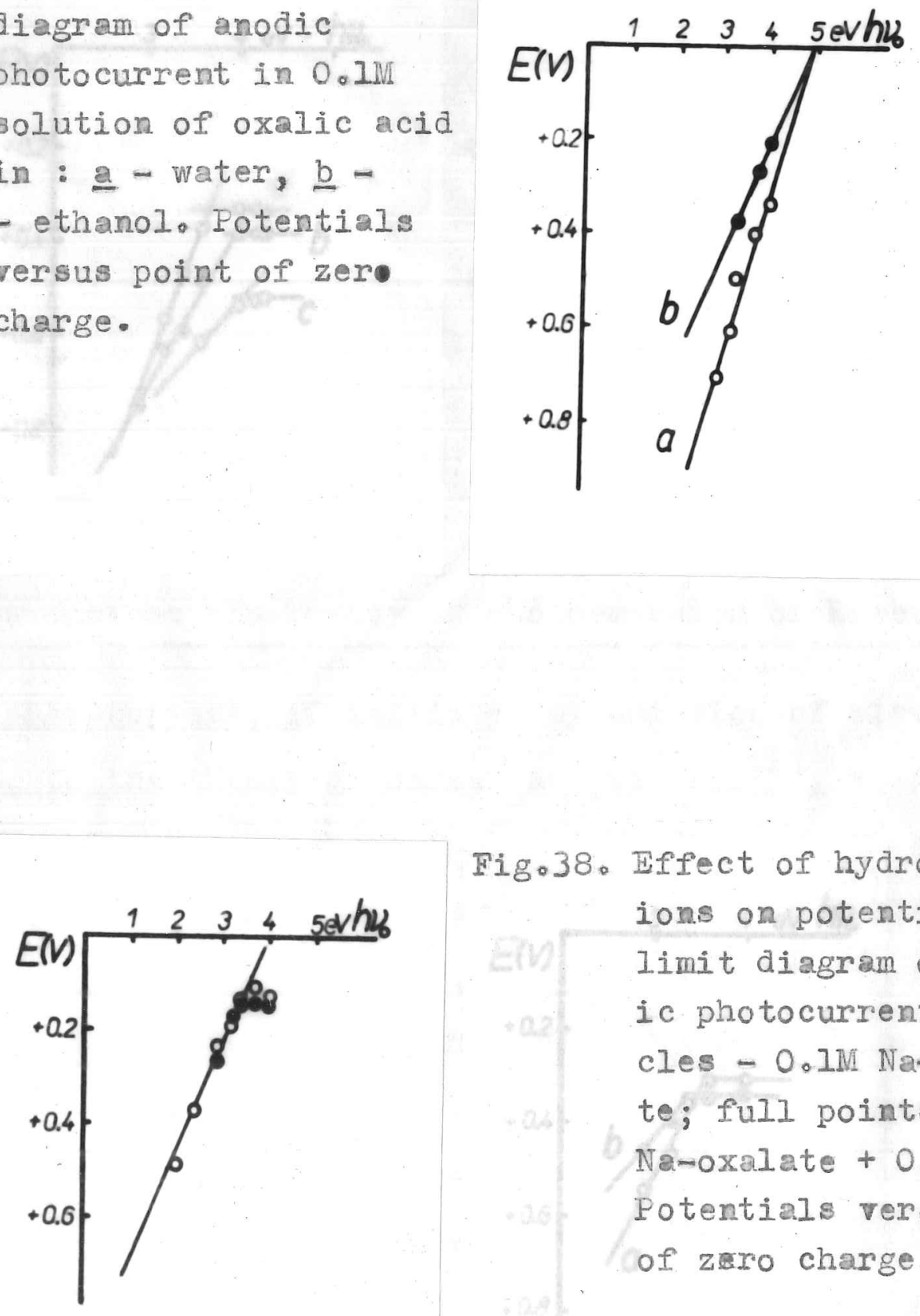

Fig.38. Effect of hydroxyl ions on potential-red limit diagram of anodic photocurrent. Circles - 0.IM Namoxalate; full points - O.IM $\mathrm{Na}$ oxalate $+0.1 \mathrm{~N} \mathrm{KOH}$ 。 Potentials versus point of zero charge. 


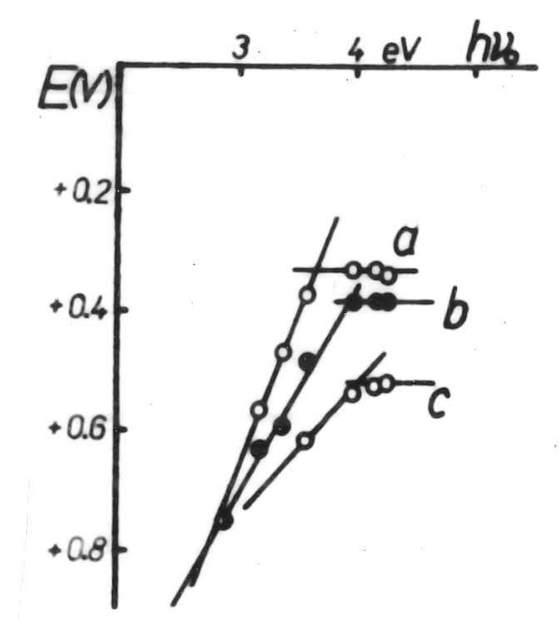

Fig.39. Potential-red limit

diagrams of anodic photocurrents in: a - $0.1 \mathrm{M}$ lactic acid, $\underline{b}-0.1 \mathrm{M}$ malic acid, $\underline{c}-0.1 \mathrm{M}$ Cl-acetic acid。 Potentials versus point of zero, charge.

Fig.40. Botential-red limit diagrams of anodic photocurrent in dilute solutions of oxalic acid. a - $10^{-2} \mathbb{M} ; \underline{b}-$ - $10^{-4} \mathbb{N}_{0}$ Potentials versus point of zero eharge.

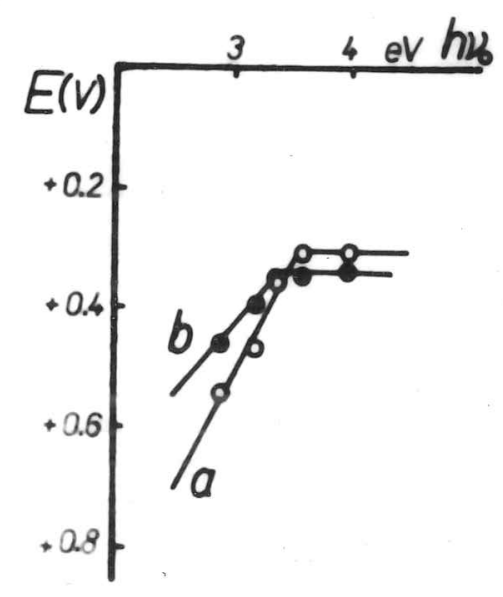




\section{Discussion}

In the discussion of results we shall concentrate upon photocurrents in aqueous solutions. The cathodic photoeurrents in ethanolic solutions, much smaller than in water, were not well accessible to measurements and therefore little can be said about their character. However, from the comparison of potential-red limit diagrams for solutions in the two solvents important conclusions can be drawn concerning the nature of the photoeffect in water.

Arguments against the Theory of Photoemission of Electrons

The photocurrent, if initiated by emission of electrons according to the theory of Barker and Gardner 21 , should be based on qualitatively the same mechanism in aqueous and ethanolic solutions. The supporting electrolyte, specificalIy the cations, have a suppressing effect on the cathodic photocurrent in water as in ethanol, since in both an increase of photocurrent is observed on dilution. This suppressing effect does not come into force in presence of the active species. There are apparently two opposing processes taking place in either solvent : one of the electrons returning back to the electrode, catalysed by cations, and the other, more rapid one, of the active species, helping to accomplish the transfer of the electrons into the solution. However, in diIute solutions appears the different nature of photoeffect in water and ethanol. The rate of a process in which electrons 
return back to the electrode can be supposed to decrease with increasing negative potential; consequently the participation of cations in the mechanism of photocurrent will also decrease. Judging from the potentialmed limit diagrams (Fig. 19), this is what happens in ethanolic solutions. In aqueous solutions, on the other hand, obviously a new reaction appears with dilution which accelerates the transfer of electrons from the electrode. This essential difference between the properties of photocurrent in the two solvents is incompatible with the idea of electron emission.

Another point where the difference of the cathodic photoeffect in water and ethanol stands out markedly is the intercept on the potential-red limit diagrams. The values of intercepts in ethanolic solutions are always higher than in aqueous solutions and have to be obtained by extrapolation : no photocurrent can be produced by light of wavelength $2800 \AA$ or 1 onger at potential of zero charge in ethanol. The smallest difference between intercepts in water and in ethanol, found in solutions of acrylonitrile, is l.2 eV. There are two factors that must be taken into consideration when comparing the intercepts. One is the difference in zero charge potentials : the potential of zero charge of meury in aqueous solutions is by about $0.2 \mathrm{~V}$ more negative than in ethanol when measured against a common reference electrode ${ }^{29}$. The other one is the difference in the interface potentials between mercury and water and mercury and ethanol. If the photocurrent were based on the same mechanism in both solvents and the differences 
were due only to different physical properties of the two systems, the value $1.2 \mathrm{eV}$ could be ascribed to the effect of differences in the interface and zero charge potentials. In that case the value $1.2 \mathrm{eV}$ should figure as a constant difference between the aqueous and ethanolic solutions in general. However, this was not found to be the case, as can be seen from Tab.I.

The intercept on the potendial-red limit diagram represents the minimal energy necessary for producing photocurrent in absence of electric field due to ionic double layer. For cathodic photocurrent, if there are no kinetic complications, the intercept corresponds to the work function referring to the escape of electron from the electrode into the solution. In case of a reaction opposing to the escape of electrons a higher value of intercept will be obtained, but under no conditions can the intercept be lower than the work function. Equation for the work function for escape of electron from metal into the solution was derived by Frumkin 30 . According to this equation after substitution of the known data for the potential of zero charge of mercury in aqueous solutions an approximate value of $2.5 \mathrm{eV}$ is obtained. Frumkin considers this value by more than $0.5 \mathrm{eV}$, lower than should be expected. The fact that some of the intercepts were found still lower (2.15 eV in solutions of iodate and bromate, $2.4 \mathrm{eV}$ in nitrate) proves that in these solutions the photocurrent cannot be caused by electron emission.

The strongest argument against the theory of electron 
emission remains the existence of anodic photocurrent which has all the properties of cathodic photocurrent but for its sign.

In order to account for the experimental results speaking against the applicability of the "physical concept" on the photoeffect in aqueous solutions, we shall approach the problem from the chemical side.

\section{Outine of the Charge-Transfer Theory}

The system metal-solution differs from the metal in vacuum not only in the presence of a new phase, but also in the existence of an interface. In the interface metal-solution various kinds of forces and bonds exist between the metal. and the components of the solution, and the interface layer can be regarded as a chemical individuality, different from the atoms or molecules in the bulk of either phase. When analysing the effect of light on a metal in a transparent solution we must take into account, besides the absorption and reflection by the metal and the outer photoeffect like for the metal in vacuum, also the absorption in the interface. This absorption in a monomolecular layer may hardly be measurable by physical means, but it can have detectable chemical consequences, like generation of a photocurrent. Matsen, Makrides and Hackerman 31 have shown that adsorption on a gietal from solution can be formulated as a charge-transfer - no-bond interaction between the metal and the 
adsorbed species. For occurence of a charge-transfer-no-bond interaction the necessary condition ${ }^{32}$ is an overlap between the highest occupied molecular orbital of the electron donor and the lowest unoccupied orbital of the acceptor. The occupation of orbitals of the electrode changes with its potential; according to the electrode potential and to the electronic structure of the partner from the solution the electrode can figure either as donor or as acceptor of electron in the surface charge-transfer complex. The bond between the donor and acceptor in the ground state of the complex may be, and usually is, very weak; however, the characteristic featu$r e$ of charge-transfer interaction is the excited state : an absorption of light quantum leads to transfer of electron from the donor to the acceptor.

The typical absorption by a charge-transfer complex occurs as a rule in the visible or near UV region at wavelengths longer than absorption due to the individual components of the complex. For energy of charge-transfer absorption it follows from the theory 33 :

$$
h \mu=I_{D}-E_{A}-G_{1}-G_{0}+X_{1}-X_{0}
$$

where $I_{D}$ is the ionization energy of the donor, $\mathbb{E}_{A}$ the electron affinity of the acceptor, $G_{I}$ and $G_{0}$ the energies of non-resonance interaction between the donor and acceptor in excited and ground states respectively, and $x_{I}$ and $x_{0}$ the corresponding resonance energies of interaction between the no-bond and dative states. 
When one of the partners of the complex is the electrode, the energy of both the ground and the excited states will depend on the electric field of the double layer. In case of electrode acting as electron acceptor the value of electron affinity $\mathbb{E}_{A}$ is given by its potential $\mathrm{E}$ :

$$
E_{A}=E_{A, 0}+\left(E-E_{0}\right) \text {, }
$$

where index 0 refers for convenience to the potential of zero charge. Each of the other terms in equation (7) can be a priori expected to depend on the double layer field. For this dependence a linear approximation may be used of the form

$$
L=L_{0}+K\left(E-E_{0}\right)
$$

where I stands for any term of $\mathrm{eq} .(7)$ and the value $\mathrm{k}$ is specific for each donor, determined mainly by its polarizability. The expression for the energy of charge-transfer absorption of the complex between the electrode and an adsorbed substance can be thus written in the form

$$
h \boldsymbol{N}=\mathbb{M}+\mathbb{N}\left(E-E_{0}\right)
$$

where $\mathbb{M}$ is the sum of the constant terms $L$ and the electron affinity $\mathrm{E}_{\mathrm{A}, O}$ referring to the potential of zero charge, and $N$ is the sum of the constants $k$.

For the opposite case when electrode plays the role of electron donor in the complex, the electrode potential stands for the ionization energy of the donor

$$
I_{D}=I_{D, 0}+\left(E-E_{0}\right)
$$


and the above considerations and equations apply mutatis mutandis. Equation (10) shows that for a charge-transfer complex in which an electrode is involved a linear relation exists between the energy absorbed and the electrode potential。

\section{Photocurrent in the Terms of Charge-Transfer Theory}

Let us'suppose that the light which passes the solution and illuminates the electrode in the present experiments is partly absorbed by the charge-transfor complex on the electrode surface according to formula (10). The transfer of electron from the donor to the acceptor in the excited state of the complex brought about by the absorption can cause an initiation of photocurrent if the return of the electron to the donor is in some way prevented. This can happen by means of a reaction sufficiently rapid to involve the complex within the lifetime of its excited state.

In the discussion of the mechanism and kinetics of photocurrent first the initial process must be considered, i.e. the formation of excited state of the complex. The rate of formation of excited state $V_{e}$, or the rate of absorption, is given by the number of photons absorbed by the surface charge-transfer complexes per unit area of the electrode in one second. For thiis number the following formula has been deduced ${ }^{34}$ :

$$
v_{e}=\alpha_{0} \frac{I}{h y} \cdot n=k_{e} \cdot n
$$


where $\alpha$ is the coefficient of absorption, $n$ the surface concentration of the complex and $k_{e}$ the rate constant of excitation. The absorption coefficient $\alpha$ is a function of frequency of light and therefore, in view of eq。 (10), also of the potential of electrode.

Equation (12) would yield the expression for photocurrent if every absorbed light quantum led to an elementary photocurrent - a definite one-way transfer of electron either from the electrode into the solution or in the opposite direction. However, the experimental results show that this do not happen. The dependence of logarithm of photocurrent on potential suggests that at lower potentials a back reaction oposes the photocurrent and that only at higher potentials a one-way electron transfer prevails. This back reaction obviously corresponds to the deactivation of the excited state. The deactivation is a complex of processes consisting in return of electron to the donor, to the ground state, which can occur with emission of radiation, either spontaneously or under the effect of light, or in a radiationless transition brought about by interaction with components of the solution - in this respect the cations are particularly efficient in cathodic photocurrent. With increasing potential the rate of deactivation can be expected to decrease, in consequence the excited state becomes more stable.

In order to find out what are the charge-transfer complexes and what are the actual reactions producing photocurrent in competition for the excited complexes with deactivation, 
we shall examine the experimental results.

\section{a) Anodic Photocurrent}

The anodic photocurrent is of the same magnitude in aqueous and ethanolic solutions which shows that the solvent does not enter into the primary photoreaction. Although absorption in the solution is excluded, the photocurrent is specific for organic compounds containing the structural group $\|_{0}^{-C}-C-$ in

the molecule (X stands for a negative substituent). Absorption of light by the metallic surface of the electrode should give rise to cathodic photoemission of electrons rather than to the observed opposite anodic photocurrent. These facts lead to the conclusion that the light absorbing species responsible for the anodic photocurrent is a complex between the dissolved substance adsorbed at the electrode and the electrode surface.

In terms of the charge-transfer-no-bond theory applied to adsorption the electrode will act as electron acceptor and the adsorbed organic substance as electron donor. The adsorption occurs most probably through the lone electron pairs on oxygen and on the negative substituent, so that in the adsorbed state a five-membered ring with the metal surface is formed. The surface complex has a characteristic absorption at longer wavelengths than the organic molecules in the bulk, and the $a b-$ sorption shifts to longer wavelengths with potential of the electrode becoming more positive, i. e. with increasing electron affinity of the acceptor, in agreement with eq. (7). 
On excitation by absorption of a light quantum an electron is transferred from the adsorbed donor to the electrode. If the electron returned back to the ground state, there would be no net direct current flowing across the interface and no photocurrent could be found polarographically. The existence of anodic photocurrent indicates that during the lifetime of the excited state some reaction takes place which prevents the return of the electron to the donor. The nature of this reaction can be inferred from photochemical behaviour of similar systems.

Bisikalova 35 found that the photoreaction of complex oxalates of mercury and some other metals in solution starts by a transfer of electron from the ligand to the central ion leading to formation of a reducing radical $\mathrm{C}_{2} \mathrm{O}_{4}^{-}$. The reducing properties of this radical have been also postulated in different other studies 36,37 . If the photoreaction of the oxalate anion adsorbed at the electrode is similar, i.e. if the oxalate anion-radical appears as dative form of the donor at the electrode surface it will be electrolytically oxidized to $\mathrm{CO}_{2}$ by giving up the second electron.

On The mechanism of the oxidation can be judged by analogy from homogeneous chemical reactions in solution. In complex oxalates the C-C bond is known to be weakened by coordination and to break easily 38,39. The oxidation of pyruvic acid $40, \quad \alpha-\mathrm{OH}$ acids 41,42 and $\alpha$-diketones 43 is believed to proceed through. formation with the oxidizing agent of intermediate cyclic complexes which after the transfer of the 
first electron break up in the C-C link between the oxygen-bearing carbon atoms, yielding reducing radicals. The irreversible step in the combined photoelectrolytical, oxidation of the present donors is probably in this breaking of the $\mathrm{C}-\mathrm{C}$ bond between the carbon atoms carrying the oxygen and the negative substituento

If the above conclusions are correct, in the case of anodic photocurrent the reaction which the charge-transfercomplex undergoes in its excited state is electrolytic oxidation. This mechanism of photocurrent can be represented by the following general scheme :

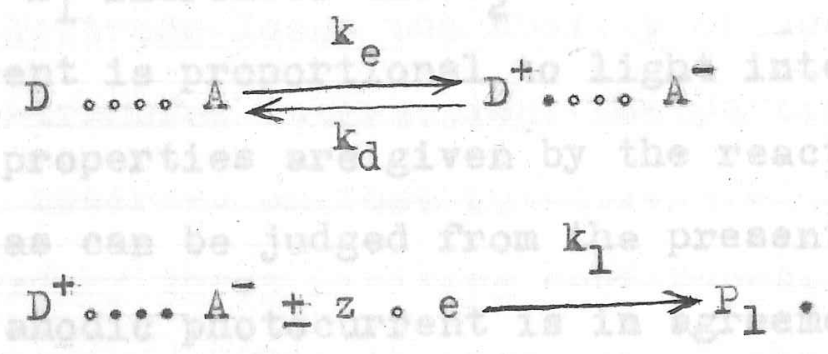

Here $D$ symbolizes electron donor, $A$ acceptor, $P_{I}$ reaction. products, $z$ number of electrons in electrode reaction, $k_{e}$ the rate constant of formation of excited state, $k_{d}$ rate constant of deactivation and $k_{I}$ the rate constant of electrode reaction.

The expression for photocurrent according to this scheme will be obtained by application of the steady-state treatment :

$$
\mathrm{k}_{e} \mathrm{n}=\mathrm{k}_{\mathrm{d}}[\mathrm{B}]+\mathrm{k}_{\mathrm{I}}[\mathrm{B}]
$$

where [B] denotes the small equilibrium concentration of 
the excited complex. From here it follows for [B]

$$
[B]=\frac{k_{e^{n}}}{k_{d}+k_{1}}
$$

and for the photocurrent $i_{p}$

$$
\frac{i_{p}}{z \cdot F \cdot q}=k_{e} \cdot n \frac{k_{I}}{k_{d}+k_{I}}
$$

where $F$ is the charge of Faraday and $q$ the surface of the electrode. Equation (13) shows that the photocurrent is directly proportional to the rate of excitation of the complex; the proportionality factor approaches unity with increasing potential, as $\mathrm{k}_{1}$ increases and $\mathbf{k}_{2}$ decreases. Consequently the photocurrent is proportional to light intensity and also its other properties are given by the reaction of excitation. As far as can be judged from the present experimental results, the anodic photocurrent is in agreement with equation (13).

Since according to our hypothesis the photocurrent is a direct consequence of absorption of light by the surface $c$ chargentransfer complex, the experimentally found linear relation between the energy of red limit of photocurrent and the electrode potential is an approximate picture of equation (10), modified by kinetics of photocurrent, specifically by the deactivation reaction. The comparison of the values of intercepts shows the relative ease with which the donors lose an electron according to their ionization energy. The intercepts vary between $3.9 \mathrm{eV}$ for oxalate anion and $6.0 \mathrm{eV}$ 
for glycine. The energy necessary for transferring electron from oxalic acid to the electrode is by $0.5 \mathrm{eV}$ lower than from dimethyl oxalate, but by $1.0 \mathrm{eV}$ higher than from oxalate anion. Similarly from tartrate anion the electron is by $0.6 \mathrm{eV}$ more easily removed than from tartaric acid.Acids forming charge-transfer complexes of a near structure, like tartaric, malic and citric, or like lactic and glycollic, have the same value of intercept.

The potential region in which donor-acceptor complexes can be formed between the electrode and a partner from the soIution is necessarily limited: with potential becoming more negative the electrode loses the ability of accepting electron in charge-transfer interaction. The partial deviations from Innearity observed on some potential-red limit diagrams can be explained by these limiting conditions.

The formation of charge-transfer complexes with the electrode as acceptor probably occurs more generally; however, most of the donors in dative state are likely to be not electrolytically oxidizable but reducible which case cannot lead to production of photocurrent.

The anodic photocurrent described could be explained on ground of one common mechanism : electrooxidation of the excited state of the donor. The cathodic photocurrent in aqueous solutions, on the other hand, represents a complex of processes among which uhder suitable conditions the elementary mechanisms can be distinguished. 


\section{b) Cathodic Photocurrent in Solutions of Scavengers}

Table 1 shows that from the species giving higher photocurrent 13 have a common intercept of $3.40 \pm 0.1 \mathrm{eV}$ which means that for production of photocurrent in solutions of compounds as different as acrylonitrile, sodium thiosulphate or hydrochloric acid at potential of zero charge of mercury the same amount of energy is needed. The only common component in all solutions giving this intercept is water. In ethanolic solutions the values of intercepts are higher and dispersed. The important rôle of water in photoeffect is confirmed by the experiment with pyridine (Fig.29) : the photocurrent increases discontinuously in the moment when the desorbed pyridine is replaced by water at the mercury surface.

Kemball 44 has found on mercury that the heat of adsorption of water is higher than of other polar solvents and that its entropy of adsorption is so large that it aeems probable that the molecules are immobile on the surface forming a monolayer. In our concept of photocurrent we suppose that these molecules are in charge-transfer interaction with the metallic surface; this time the electrode functions as electron donor and water as electron acceptor. An absorption of light quantum brings about a photochemical transfer of electron from the electrode to the adsorbed molecule of water. In this way in the excited state there is on the electrode surface a molecule of water bearing a negative charge; it reminds of the hydrated electron ${ }^{45}$ but differs from it in localization of the charge. 
Before the electron returns to the ground state to the electrode it can be removed from the water molecule by a fast reaction with an active component of the solution. These active components causing high cathodic photocurrents according to Tab.l, are efficient scavengers of hydrated electrons with the exception of thiosulphate and thiocyanate ions 46. Thiosulphate is known to react readily with atomic hydrogen 47 which suggests that the water molecule carrying a negative charge is in equilibrium with hydrogen atom and hydroxyl anion. The reaction can be schematically expressed.

Ne ... $\mathrm{H}_{2} \mathrm{O} \frac{\mathrm{k}_{\mathrm{e}}}{\mathrm{k}_{\mathrm{a}}} \longrightarrow \mathrm{Me}$.0. $\left(\mathrm{H}_{2} \mathrm{O}\right)=\mathrm{Me} \ldots\left(\mathrm{H}+\mathrm{OH}^{-}\right)$.

In alkaline solutions the ability of the negatively charged water molecule to react as $\mathrm{H}$ and $\mathrm{OH}^{-}$is reduced. This can explain why addition of potassium hydroxide causes a shift of the intercept in solutions of thiocyanate and thiosulphate; their reaction with atomic hydrogen is apparently higher than with electron. The other scavengers having the cotmon intercept - nitrous oxide, acrylonitrile and nitrate ion - react rapidly with electron in neutral and alkaline solutions, and an addition of alkaline hydroxide does not affect their intercept.

The variety of slopes of the straight lines on potential-red limit diagrams in aqueous solutions of electron and hydrogen atom scanvengers indicates that the absorption by the 
charge transfer complex water-electrode and the kinetics of scavenging reactions are specifically affected by the field of the double layer. However, all the differences disappear at potential of zero charge in absence of the ionic double layer when the photocurrent is given only by the difference between the rate of the photochemical transfer of electron from the electrode to the water molecule and the rate of an elementary deactivation reaction which, judging from the dependence of photocurrent on potential, occurs even in the solutions of efficient scarengers. The energy necessary for this process corresponds to the common value of intercept, $3.4 \mathrm{eV}$.

The reaction of transfer of electron to water is well known in photochemistry of aqueous solutions. Dainton and James 48 found a linear relation between the energy of red Iimit of charge-transfer band in absorption spectra of a series of hydrated transition metal cations and their standard redox potentials. The energy of the long-wave limit of absorption in this series is separable into two terms 49 , namely the ionization energy of the reduced form, and a constant term characteristic of water molecule and its ion and radical. The ionization energy of a noble metal electrode in solution changes according to its applied potential; at potential equal to the standard potential of a redox system it is equal to the ionization energy of the reduced form of the couple. At potential of its zero charge $(-0,2 \mathrm{~V}$ sersus normal hydrogen electrode) willfmercury in aqueous solution have about the 
same ionization energy as the hydrated vanadous ion. The energy of red limit of charge-transfer absorption of vanadous solution is, according to the above authors' results, 81 kcal, or $3.5 \mathrm{eV}$. The fact that this amount of energy necessary for the transfer of electron to water is near the minimum energy for production of photocurrent, $3.4 \mathrm{eV}$, is in agreement with our hypothesis about the nature of photocurrent.

The value of the energy of red limit of photocurrent at potential of zero charge of mercury, the $3.4 \mathrm{eV}$, obviously corresponds to the value of the work function referring to the escape of electron into aqueous solution, estimated by Frumkin 30 as higher than $3 \mathrm{eV}$.

A transfer of electron to adsorbed water molecule has been suggested as primary reaction in heterogeneous photoprocesses on surfaces of zinc oxide 50 and anthracene 51 . The concept of water as electron acceptor in charge-transfer interaction between water and aromatic hydrocarbons appeared in a paper by Bohon and Claussen 52 .

Valnev 53 found that water vapour when adsorbed on cadmium or zinc is decomposed by light of energy by $2 \mathrm{eV}$ lower than when in gas phase, with simultatieous evolution of hydrogen, in a mechanism independent of photoemission; it seems that this effect could be interpreted on ground of photoexcitation of a charge-transfer complex between the metal and adsorbed water, like in our case.

From the discussion of the cathodic photocurrent in aqueous solutions of scavengers we may conclude that here 
the excited state is formed betweeh the electrode and a common acceptor, water molecule, and that from the acceptor the electron either returns to the donor or is removed by a chemical reaction with the scavenger. For this mechanism following scheme applies :

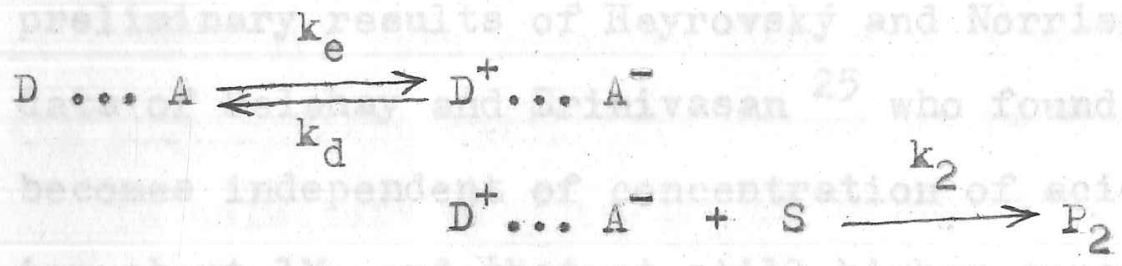

where S stands for scavenger, and other symbols have the same meaning as in the case before.

The steady state condition on illumination:

$$
k_{e} n=k_{d}[B]+k_{2}[B] \cdot[S]
$$

leads to the expression for intermediate concentration of excited complex

$$
[B]=\frac{k_{e} n}{k_{d}+k_{2}[s]}
$$

and for the photocurrent

$$
\frac{i_{p}}{F_{0} q}=k_{e} \cdot n \frac{k_{2}[s]}{k_{d}+k_{2}[s]} \text {. }
$$

Here again the photocurrent is directiy proportional to the rate of excitation of the complex; the proportionality factor approaches unity at high concentration of scavengers ahd with increasing potential, when $\mathrm{k}_{\mathrm{d}}$ decreases. Like in case of anodic photocurrent, the cathodic photocurrent is directly proportional to the light intensity and on the light fre- 
quency and electrode potential depends according to the excitation reaction. The dependence of the photocurrent on concentration of scavenger is nonlinear and tends to a limit. Experimental evidence is in favour of equation (14). The postulated dependence on scavenger concentration agrees with preliminary results of Heyrovsky and Norrish 24 and with the data of Delahay and Srinivasan ${ }^{25}$ who found that photocurrent becomes independent of concentration of acid at concentration about IM, and that at still higher concentrations it decreases. The decrease is probably due to interference of acid with the charge-transfer interaction of water at the electrode surface。

The seemingly anomalous behaviour of the two efficient electron scavengers, bicarbonate ion and acetone, can be explained on basis of an electrolytic back reaction. Bicarbonate anion when adsorbed at positively charged electrode reacts with the excited state of the complex like an acid, as indicates the intercept $3.3 \mathrm{eV}$ (Fig.25). On negatively charged electrode no bicarbonate anions are adsorbed, but as electron scavenger in the vicinity of the electrode will act the molecule of carbon dioxide ${ }^{54}$ present in the solution in equilibrium. However, the molecule of $\mathrm{CO}_{2}$ on accepting an electron turns into a reactive reducing radical $\mathrm{CO}_{2}^{-}$ready to give up the electron to the electrode as long as its potential is sufficiently positive. Under these conditions the molecule of carbon dioxide functions as an efficient deactivator of excited charge-transf er complexes on the electrode 
surface. It is only at potentials more negative than $-1.0 \mathrm{~V}$ versus potential of zero charge that $\mathrm{CO}_{2}^{-}$retains the electron and $\mathrm{CO}_{2}$ behaves as electron scavenger producing a high photocurrent. Similarly with acetone in aqueous solution the radical $55\left(\mathrm{CH}_{3} \mathrm{COCH}_{3}\right)^{-}$is evidently electrolytically oxidized at potentials less negative than $-1.0 \mathrm{~V}$ and there suppresses the photocurrent until this potential is reached.

In solutions with values of intercepts higher than 3.4 $\mathrm{eV}$ the solutes also react at the electrode with the negativeIy charged water molecule or with atomic hydrogen, but their reaction is not sufficiently fast for a successful competition with deactivation processes; in accordance with equation (14) the photocurrent becomes smaller with decreasing $k_{2}$.

\section{c) Cathodic Photocurrent in Indifferent Electrolytes}

In the inert $0.1 \mathrm{M}$ aqueous solutions with intercepts between 4.0 and $4.5 \mathrm{eV}$ the rate of deactivation $\mathrm{k}_{\mathrm{d}}$ is high and the only thinkable scavenger is water itself 56 which, however with its very small value of $\mathrm{k}_{2}$ would produce hardly any measurable current. It seems more probable that the photocurrent observed in absence of scavengers is due to a bimolecular reaction between two excited complexes. With water molecule as acceptor the product of such reaction will be hydrogen molecule and two $\mathrm{OH}^{-}$ions like in the reaction between two hydrated electrons 57 . This mechanism could account for the above mentioned Valnev's experiment ${ }^{53}$. In our symbols the scheme is as follows: 
$D \ldots A \underset{k_{d}}{\stackrel{k_{e}}{\underset{k_{d}}{\longrightarrow}} D^{+} \ldots A}$

$$
D^{+} \ldots A^{-}+D^{+} \ldots A^{-} \stackrel{k_{3}}{\longrightarrow} P_{3} \text {. }
$$

From the steady-state condition

$$
k_{e} \cdot n=k_{d}[B]+k_{3}[B]^{2}
$$

the concentration of excited complex is obtained

$$
[B]=\frac{-k_{d}+\sqrt{k_{d}^{2}+4 k_{3} k_{e}^{o n}}}{2 k_{3}}
$$

by means of which after a small arrangement the expression for photocurrent is given

$$
\frac{i_{p}}{F q}=k_{e} \cdot n-\frac{k_{d}^{2}}{2 k_{3}}\left(\sqrt{1+\frac{4 k_{3} k_{e} \cdot n}{k_{d}^{2}}}-1\right) .
$$

The photocurrent according to equation (15) is always smaller than the rate of excitation, since, as we have seen, $k_{d}>0$. Its magnitude depends above all on the rate of deactivation $\mathrm{k}_{\mathrm{d}}$ 。

Dilution brings about a decrease of concentration of cations favouring the deactivation and therefore an increase of photocurrent is to be expected. However, since the ionic concentration in the double layer, which is clearly most important in deactivation, is an exponential function of the ionic charge 58 , the effect of dilution on the back reaction will depend strongly on the valency of cations. The photocurrent in diluted aqueous solutions in absence of scavengers demonstrates this dependence. 
In solutions of efficient scavengers no effect of valency of cation of the supporting electrolyte on photocurrent was observed (Fig.28) - evidently because here the deactivation reaction is suppressed and plays but a small rôle besides the scavenging (eq.14), whereas in absence of scavengers its role becomes determining for the photocurrent (eq.15). An increase of photocurrent in $10^{-6} \mathrm{M} \mathrm{KCl}$ after introduction of electron scavengers into the solution (Fig.30) indicates that the deactivation reaction at this dilution is still considerable, as can be also judged from the intercept on potential-red limit diagram (Fig.I7)。

\section{d) Cathodic Pholtocurrent-Special Cases}

It has been shown that the value $3.4 \mathrm{eV}$ of intercept of the straight lines on potential-red limit diagram is given by the energy of electron transfer to water molecule. The cases where the value of intercept is found lower than 3.4 eV cannot be explained by donormacceptor interaction between electrode and water. The acceptors are here apparently either the anions of the dissolved compounds or species formed from them in solution. Tellurate, bromate and iodate are electrolytically reducible and it can be expected that if after the phototranfer of an electron a radical-anion is formed, it will be further reduced on the electrode. Such mechanism would be exactly analogous to the anodic photocurrent, and the photocurrent would follow equation (13). The shift of the intercept by potassium hydroxide might indicate that the 
acceptor in neutral solution is not anion, but the corresponding acid formed in small concentration in solution by hydrolysis and adsorbed at the electrode surface, and that the anions appear in the charge-transfer complex only in alkaline solution. Nitric acid which is the only strong acid having the intercept lower than $3.4 \mathrm{eV}$, also probably enters directly into donor-acceptor complex with the electrode and is reduced in excited state. The nitrate anion, on the other hand, reacts as a scavenger of electrons yielding the intercept $3.4 \mathrm{eV}$ 。

Slightly different is the problem with solutions of nitrite. Nitrites in aqueous solutions are known to hydrolyse slightly forming nitric oxide No 59. From the polarographic behaviour of nitric oxide Rampazzo and Cardinali 60 concluded that the compound is adsorbed at the electrode in the inner part of the compact double layer. We have tried to ascertain the adsorption of No on the dropping mercury electrode by means of electrocapillary curves. The curves obtained by measuring the time of 10 drops are shown on Fig.4I and 42. The surface tension on mercury in neutral solution of sodium nitrite increases after addition of alkali gydroxide and bubbling nitrogen through the solution - it is because in this way hydrolysis is suppressed and No expelled from solution (Fig.4I). A direct proof of adsorption of No on the electrode is brought on Fig.42 where after dissolution of No in alkaline solution the surface tension is lowered. Nitric oxide is therefore apparently the acceptor in surface charge- 
Fig.41. Effect of hydroxyl ions on the electrocapillary curve of nitrite solution. a - 0.1M $\mathrm{NaNO}_{2} ; \underline{b}-$ $-0.1 \mathrm{M} \mathrm{NaNO} \mathrm{Na}_{2}+0.2 \mathrm{M}$ NaOH. Electrocapillary curves measured as time of 10 drops; in atmosphere of nitrogen; potentials versus silver chloride electrode.

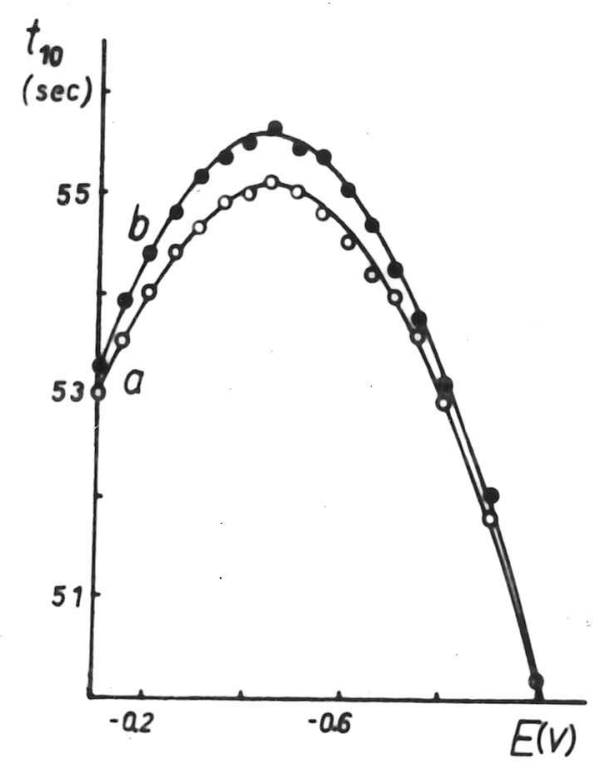

Fig.42. Effect of nitric oxide

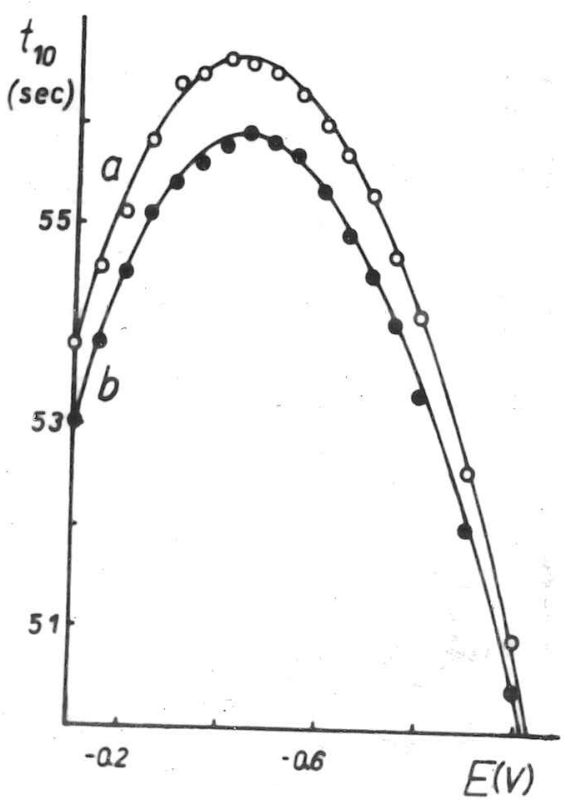
on electrocapillary curve of alkaline solution. a - $0.6 \mathrm{M} \mathrm{NaOH}$; $\underline{b}-0.6 \mathrm{M} \mathrm{NaOH}$ after bubbling of $10 \mathrm{ml}$ of No through the solution. Conditions like on Fig॰4I. 
-transfer complex with the electrode in neutral solutions of nitrite. The photexcitation of nitrite. The photooxidation of the complex is probably accompanied by an irreversible electroreduction, judging from polarographic results. In alkaline solutions of nitrites no NO is formed and the $\mathrm{NO}_{2}^{-}$ion behaves like a strong electron scavenger in photoreaction between electrode and water, with intercept $3.4 \mathrm{eV}$ on the potential-red limit diagram。

\section{Potentiometric Effects}

It remains to explain in terms of the theory of photochemical charge-transfer the shifts of potentials of mercury pool electrode on illumination. If the experiments are carried out in aqueous solutions of inert electrolytes, the charge-transfer complex with the electrode will be formed by water molecules. It is known 61 thataatomic hydrogen causes a shift of potential of mercury electrode to negative values。 Because the molecule of water as acceptor in excited state can react as atomic hydrogen, the illumination of electrode by constant light is equivalent to maintaining a certain very low constant concentration of hydrogen atoms at the surface. Besides that, on stationary electrodes all traces of impurities accumulated from the solution are subject on illumination to the reducing effect of electrons or hydrogen atoms, and their slow reduction will impart to the electrode a trend towards negative potentials. Oxygen will immedia- 
tely react with negative water molecules under formation of oxidizing radicals $\mathrm{O}_{2}^{-}$or $\mathrm{HO}_{2}$ which will shift the potential in positive direction.

Conclusion

The "chemical" concept of the electrochemical photoeffect based on photochemical charge-transfer reactions between the electrode and components of the solution seems to suceed in explaining a variety of experimental facts. However, more thorough and, above all, quantitative investigation is necessary to prove how far the idea of charge-transfer complexes with the electrode is justified. Comparison of theoretical equations (12), (13) and (14) with the empirical formula (5) shows that the dependence of the absorption coefficient on the frequency of light and on the electrode potential ought to be exponential. This is the most essential conclusion which must be checked on ground of quantitative results before further work can be done on the photo-electrochemical charge-transfer. 


\section{Surmary}

On illumination of aropping mercury electrode in transparent solutions both cathodic and anodic photocurrent can be observed. The cathodic photocurrent appears in every solution, anodic photocurrent was observed only in presence of organic substances bearing $a=C=0$ group and a negative substituent on the neighbouring carbon atom.

The cathodic photocurrent increases with dilution of supporting electrolyte; the increase depends on the charge of the cation being greatest in solutions of univalent and negligible in solutions of trivalent cations.

A particularly high cathodic photocurrent appears in solutions of scavengers of electrons or hydrogen atoms. The energy necessary for production of photocurrent in aqueous solutions of scavengers at potential of zero chrage is consto

tant and equal $3.4 \mathrm{eV}$.

The photocurrent is a faradaic current, it is directly proportional to light intensity and increases exponentially with the electrode potential and with the energy of light. Between the energy of red limit of photocurrent and electrode potential a linear relation holds.

In order to interpret all the experimental facts a theory is proposed based on photochemical charge-transfer between the electrode and a component of the solution. This theory. in contradistinction to the theory of electron emission 10cates the primary act of light absorption in a surface charge-transfer complex with the solvent or a solute in which 
the electrode plays the rôle of either electron donor or acceptor. The excited surface complex either is deactivated or undergoes a reaction yielding photocurrent.

The anodic photocurrent is explained by electrolytic oxidation of donor - the organic molecule - in dative state. In aqueous solutions of scavengers the charge-transfer complex is supposed to be formed with the water molecule as acceptor which in excited state bears an electron capable of reaction with the scavengers. In some cases a direct participation of the solute in charge-transfer complex with the electrode is postulated. The photocurrent in aqueous solutions without scavengers is ascribed to bimolecular reaction of excited complexes.

Experimental results were found in qualitative agreement with the proposed theory. For the three different mechanisms of photocurrent equations were derived, however, the present simple experimental arrangement did not allow their quantitative verification. 


\section{References}

1. Becquerel $E_{0}:$ Compt.Rend.2, 145 (1839).

2. Copeland A.W., Black O.D。, Garret A。B॰: Chem。Rev。 1 , 177 (1942)。

3. Paszyc S.: Wiadomosci Chemi.12, 767 (1958).

4. Mauser Ho, Sproesser U。: Chem。Ber.27, 2260 (I964)。

5. Trümpler Go: Z.Physik。Chem。(Leipzig) 20, 385 (1915)。

6. Rideal E.Ko, Norrish R.G.W०: ProcoRoy.Soc。(London) Ser.A 103, 342 (1923).

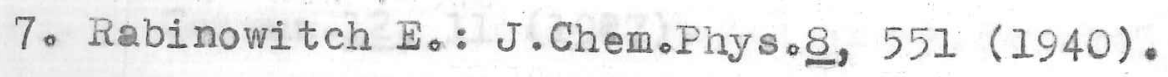

8. Surash JoJ., Hercules D。H。: J.Phys.Chem.66, 1602 (1962)。

9. Berg H., Z.Chem。2 237 (1962).

10. Berg Ho, Schweiss Ho: Nature 191, 1270 (1961)。

11. Volmer Mo, Moll W。: Z。Physik。Chem。(Leipzig) 161, 401 (1932)。 12. Athanasiu $G_{0}$ : Ann.Phys.(Paris) 4, 377 (1935)。

13. Veselovsky V。I。: Zh॰Fiz。Khim。22, 1427 (1948)。

14. Winther Co: Z。Physik。Chem。(Leipzig) 131, 205 (1927)。

15. Swensson To: Arkiv Kemi, Mineral。Geol.I, I (1919)。

16. Lifschitz J。, Hooghoupdt S.B。: Z。Physik。Chem。(Leipzig)

$$
\text { 141, } 52 \text { (1929)。 }
$$

17. Audubert Ro: JoChim。Phys.27, 169 (1930)。

18. Bowden F.Po: Trans.Faraday Soc.27, 505 (1931)。

19. Price L.E。: Thesis。 Cambridge University 1938.

20. Hillson P.J., Rideal E.K.: Proc.Roy.Soc.(London) Ser.A 192, 295 (1949)。

21. Barker G,Co, Gardner A.W०: Paper presented on the 14 the Meeting of CITCE, Moscow 1963 (extended abstract), 
22. Berg H., Schweiss H。: Electrochim.Acta 2, 425 (1964)。 23. Berg Ho, Schweiss Ho: Wonatsber.Deut.Akad.Wiss.Berlin 2, $546(1960)$.

24. Heyrovský Mo, Norrish R。G.W०: Nature 200, 880 (1963)。 25. Delahay P., Srinivasan V.S.: J.Phys.Chem.70, 420 (1966)。 26. Leighton P.A., Crary R.W., Schipp I.T.: J.Am.Chem.Soc.53, 3017 (1931).

27. Smoler I.: J.ElectroanaI.Chem。ㅁ, 465 (1963)。 28. Heyrorský J., Sorm $F_{\bullet}$, Forejt J.: Collection Czech.Chem。 Commun.12, II (1947).

29. Frumkin A.No: Z.Physik。Chem.(Leipzig) 103, 43 (I923)。 30. Frumkin A.N०: J.Electroanal.Chem。2, 173 (1965). 31. Matsen F.A., Makrides A.C., Hackerman U。: J.Chem。Phys。 22, 1800 (1954).

32. Mulliken RoS。: Rec.Trav。Chim。75, 845 (1956)。

33. Muliken R.S., Person W.B.: Ann.Rev.Phys.Chem.13, 107 (1962)。

34. Moelwyn-Hughes E.A.: Physical Chemistry. Pergamon Press 1957, p.1177。

35. Bisikalova N.A.: Ukr。Khim.Zh.11, 815 (1951)。

36. Abel.E.: Monatsh.Chem.83, 695 (1952)。

37. Saffir P., Taube Ho: JoAm.ChemoSoc.82, 13 (1960)。

38. Sakurabe S., Ikeya S.: BuJ.I.Chem.Soc.Japan 30, 662 (1957).

39. Duke F。R०: JoAmoChem。Soc.69, 2885 (I947)。

40. Drummond A.Io, Waters W.A.: J.ChemoSoc.1955, 497.

41. Levesley $P_{0}$, Waters WoAo: JoChemoSoc.1955, 217.

42. Gupta $K_{0} K_{0} S_{\bullet}$, Aditya So: JoElectrochem.Soc.J apan, 
Overseas Ed. 32,201 (1964).

43. Shiner V.J., Washuth C.R.: J.Am.Chem.Soc.81, 37 (1959). 44. Kembal1 C.: Proc.Roy.Soc.(London) Ser.A 190, 177 (1947). 45. Hart E.J.: Science 156, 19. (1964).

46. Thomas J.K., Gordon S., Hart E.J.: J.Phys.Chem.68, 1524 (1964)。

47. Harteck Po, Stewart Ko: Z.Phys\%.Chem。(Leipzig) 18I, 183 (1938)。

48. Dainton F.S., James D.G.I.: J.Chim.Phys.48, C I7 (1951)。 49. Dainton F.S., James D.G.L。: Trans.Faraday Soc. 24,649 (1958)。

50. Markham M.Co, Laidler K.J.: J.Phys.Chem.57, 363 (1953)。

51. Kallmann $H_{0}$, Pope M.: Nature 185, 753 (1960)。

52. Bohon R.L., Claussen W.F。: J.Am.Chem.Soc.73, 1571 (1951)。

53. Valnev $P_{0} E_{0}:$ Zh.Fiz.Khim.30, 1308 (1956)。

54. Getoff $N_{0}$ : Discussions Faraday Soc.36, 314 (1963)。

55. Rabani Jo, Stein Go: J.Chem.Phys.37, 1865 (1962)。

56. Jortner Jo, Ottolenghi Mo, Stein Go: J.Phys。Chem.68, 247 (1964).

57. Gordon S., Hart E.J., Matheson M.S., Rabani J., Thomas J.Ko: Discussions Faraday Soc.36, 193 (1963)。

58. Grahame D.C.: Chem.Rev.41, 441 (1947).

59. Pascal Bo: Nouveau traité de chimie minérale. Vol.10, p.434, Niasson et cie, Paris 1956.

60. Rampazzo L., Cardinali M.: RicoSci.Rend.4, 141 (1964). 61. Levina C.D., Kalish T.V.: Zh.Fiz.Khim.36, 1926 (1962)。 


\section{Contents}

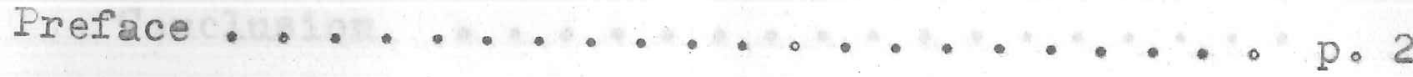

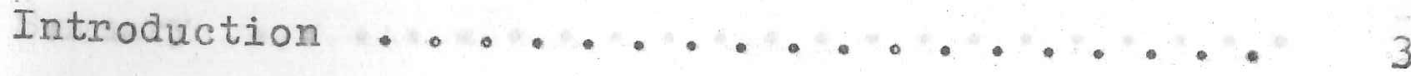

Experimental $\cdots \cdots \cdots \cdots$ II

Results $\ldots \ldots \ldots \ldots \ldots \ldots$

A. Potentiometric Measurements ....... I

B. Polarographic Measurements ....... 19

Photocurrent, General Properties ..... 21

Dependence of Photocurrent on the Frequency of light ............... 25

Potential-Red Iimit Diagrams ...... 30

Cathodic Photocurrent

in Indifferent Electrolytes ... 33

in Specifically Active Solutions 。 37

Anodic Photocurrent ......... 47

Discussion ................ 56

Arguments against the Theory of Photo-

erission of Electrons ......... 56

Outline of the Charge-Transfer Theory ... 59

Photocurrents in the Terms of Charge-

-Transfer Theory ........... 62

a) Anodic Photocurrent ............ 64

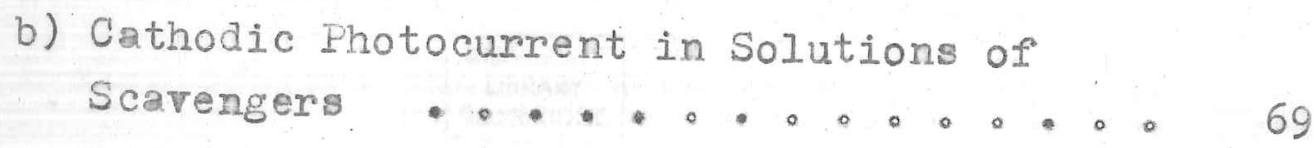

c) Cathodic Photocurrent in Indifferent Electrolytes .......... 75

d) Cathodic Photocurrent, Special Cases.。 77 
Potentiometric Effects ......... p. 80 Conclusion ................. 81

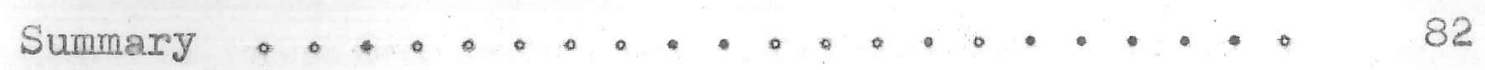
References ..................... 84.

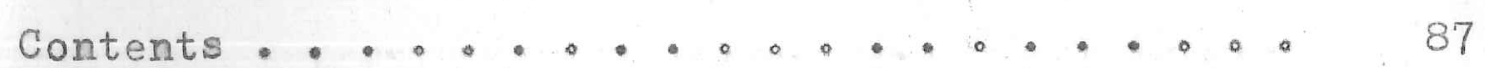


I declare that the work presented in this dissertation is original, and that every source from which any information has been derived, is stated in references.

I also declare that neither this dissextation nor any part of it had been submitted for a degree or diploma or other qualification at any other University.

M. Heyrows' 


\section{Pa. D. Dissertation \\ 5572}

(Reprinted from Nature, Vol. 200, No. 4909, pp. 880-881,

\section{Photovoltaic Phenomena in Aqueous} Solutions

RESULTS of our potentiometric measurements of the photovoltaic effect in the ultra-violet region on platinum and mercury electrodes in aqueous solutions of sulphuric acid, potassium hydroxide and potassium sulphate led us to the conclusion that the observed potential changes of the illuminated electrode are caused by a competitive action of oxidizing and reducing species formed in water under the incident light.

A confirmation of this hypothesis has boen found on examining the same solutions polarographically under constant irradiation by a high-pressure mercury lamp. Whereas no observable change appears on polarographio curves of deaerated solutions of potassium hydroxide and potassium sulphate when exposed to light, a rapid in crease of current of the magnitude about 10-8 amp (Fie follows the illumination of the dropping more in solutions of in solutions of sulpha prod, the curent falls back to its original value. The production of cur fo appear at potentials by about $0.6 \mathrm{~V}$ more positive than the rise of the reduction current due to electrolytic evolution of hydrogen, and it increases with increasing negative potential of the dropping electrode. With increasing concentration of hydrogen ions up to about $1 \mathrm{~N}$ the current caused by light increases; further from there it begins to diminish. In water-ethanolic solutions of sulphuric acid the photocurrent is smaller by about $1 / 2$ than in aqueous solutions.

Qualitatively the same phenomenon was observed, with solutions of perchloric, hydrochloric and acetic acids. Besides the appearance of this relatively small current on the foot of the wave the actual polarographic reduction wave of hydrogen ions is not affected by illumination. There was found no effect whatever of ultra-violet light on the foot of the polarographic reduction waves of oxygen, $\mathrm{Cd}^{4+}, \mathrm{Zn}^{2+}$ or $\mathrm{Ni}^{2+}$ ions. Nitrous oxide dissolved oxygon, Cat Zn or pissolved undere atmose curent in aid solutions and introducos an identical effect in solutions of potassium sulphate and potassium hydroxide.

The described experimental results could be interpreted on the basis of the effect of the photosensitized decomposition of water on the electrode surface. The metallic atoms in the surface of the electrode excited by the incident quanta of light transfer energy to the adsorbed molecules of water. It can be assumed that the dissociation products of water, $\mathrm{H}$. and $\mathrm{OH}$. radicals, 
are also adsorbed at the electrode surface, and thăt their heat of adsorption is greater than that of the water molecule. In that case, quanta of lower energy whan $118 \mathrm{keal} / \mathrm{mole}$ (that is, light of longer wave-length than $2422 \mathrm{~A}$ ) can lead to splitting of the $\mathrm{H}-\mathrm{OH}$ bond in water. (The potential changes in all solutions and the production of photocurrent in acid solutions were observed to a small extent also with ultra-violet light of $\lambda$ above $3200 \AA$.$) The radicals formed recombine rapidly to water,$ molecular hydrogen or hydrogen peroxide. The occurrence of the reaction products at the electrode surface results in a change of potential of the inert electrode, the extent and the direction of which depend on experimental conditions. However, the concentration of the electroactive species is not high enough to cause a measurable polarographic current.

In solutions of acids the hydrogen ions adsorbed at the negatively charged electrode combined with photolytically generated hydrogen atoms to form $\mathrm{H}_{2}^{+}$. By this reaction the equilibrium between decomposition of water and recombination of its radicals is disturbed, and the total recombination of its radicals is disturbed, and the total reaction now results partly in formation of $\mathrm{H}_{2}$ and $\mathrm{OH}$, which can both be reduced at the olectrode in an extent sufficient to produce a polarographic current.

A similar mechanism occurs in the presence of $\mathrm{N}_{2} \mathrm{O}$ which turns hydrogen atoms into $\mathrm{OH}$ radicals. Alcohol, on the other hand, acts as a seavenger of $\mathrm{H}$ and $\mathrm{OH}$, changing them into water or molecular hydrogen, and thus sup-

presses to a certain extent the production of current.

A photosensitized decomposition of water could well account for experimental results published by other

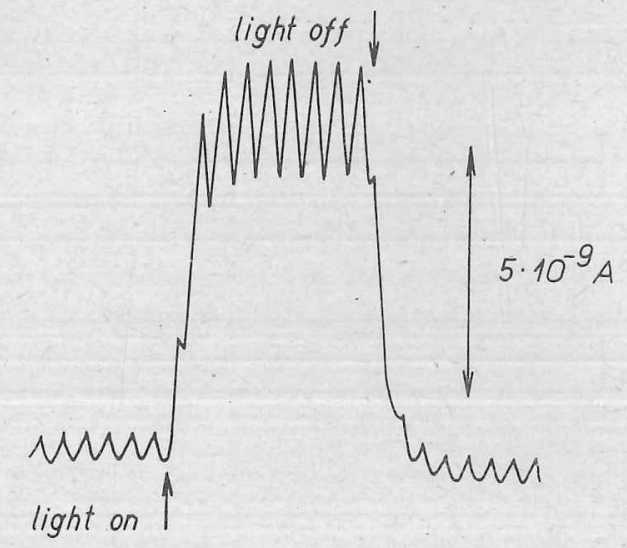

Fig. 1. Polarographic current in deaerated $1 \mathrm{M} \mathrm{H}_{2} \mathrm{SO}_{4}$ at constan dropping electro authors on photovoltaic phenomena in aqueous solutions ${ }^{1-8}$ as well as on the acceleration of electrodeposition of hydrogen and oxygen by ultra-violet light ${ }^{4-6}$.

Polarographic Institute

$$
\text { M. HeYRoviśr }
$$

Czechoslovak Academy of Sciences,

$$
\text { Prague, }
$$

and University of Cambridge.

R. G. W. NORRISH

Department of Physical Chemistry,

University of Cambridge.

'Swensson, T., Arkiv Kemi, Min. och Geologi, \%, No. 19, 1 (1919). 'Lifsehitz, J., and Hooghoudt, S. B., Z. phys. Chem., A, 141, 52 (1929). ${ }_{4}^{4}$ Bowden, F. P. Trans. Farud, Soc, 2 , 505 (1981).

5 Price, I T Dissertation Cambridse Unive (1008).

${ }^{6}$ Hillson, P. J., and Rideal, E. K., Proc. Roy, Soc., A, 199, 295 (1949). 


\section{Phi, D. Dissertation 5572}

(Reprinted from Nature, Vol. 206, No. 4991, pp. 1356-1357, fune 26,1965 )

\section{Nature of the Photoeffect in Aqueous Solutions}

As has been already reported ${ }^{1-3}$, a photocurrent is produced when a dropping mercury electrode is sufficiently strongly illuminated in solutions not absorbing the light.

Further investigation of this effect shows that in various solutions cathodic and anodic photocurrents can be obtained and that the cathodic photocurrent is particularly high if the solution contains a scavenger either of electrons or of hydrogen atoms. A plot of energy of the red limit of photocurrent against potential of the electrode gives a straight line (Fig. 1) the slope of which indicates the dependence of the photoprocess on potential; the red limit at the potential of zero charge gives the energy necessary for production of photocurrent in absence of electric field due to ionic double layer.

From an examination of a number of solutions it appears that the cathodic photocurrent is as a rule higher by more

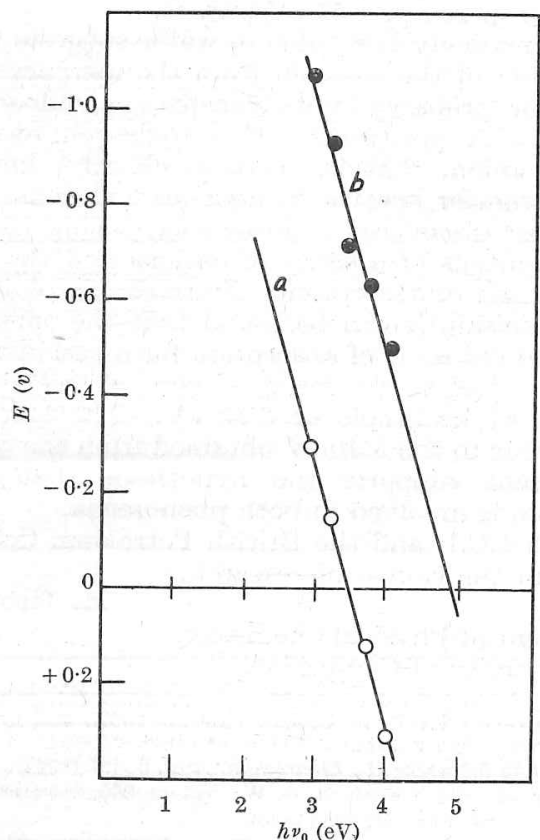

Fig. 1. Relation between the energy of red limit of photocurrent, and the ethanol. Potentials m LiCl saturated with $\mathrm{N}_{2} \mathrm{O}$. $a$, In water; $b$, 


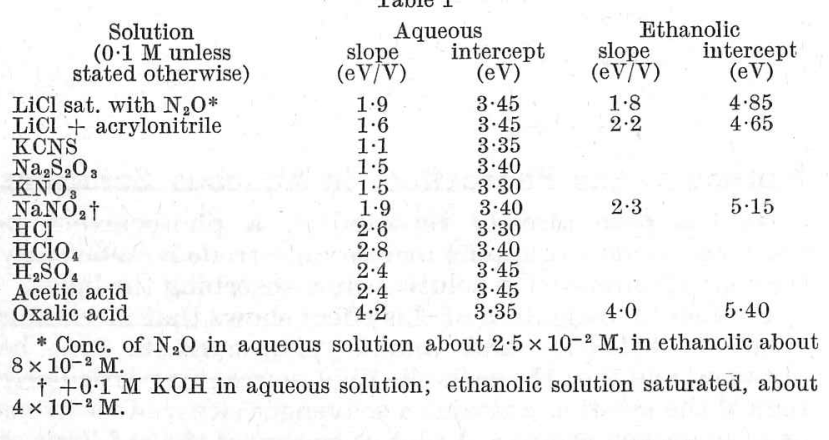

than one order in water than in ethanol. Table 1 compares parameters of the potential - red limit diagrams for some solutions yielding especially high photocurrents. With aqueous solutions the straight lines, although of different slopes, all have a common intercept at the potential of zero charge corresponding to $3 \cdot 40 \mathrm{eV}$ (within the limits of experimental error). In ethanol, on the other hand, there is a wide dispersion of the intercepts, the lowest value being $4.65 \mathrm{eV}$, slightly higher than the work function of mercury, $4.53 \mathrm{eV}$ (ref. 4).

The surprisingly low value in water suggests that there the emission of the electron from the mercury surface is made easier, probably by its transfer to an adsorbed water molecule with production of a hydrogen atom and a hydroxyl anion, that is, by a mechanism known from electron transfer spectra in aqueous solutions. Dainton and James ${ }^{5}$ discovered a linear relationship between the redox potentials of a series of cations and the energy of their red limit of absorption. From the graph illustrating this relationship it can be found that the energy corresponding to red limit of absorption for a cation with redox potential equal to potential of zero charge of mercury would be $81 \mathrm{kcal} / \mathrm{mole}$ or $3.55 \mathrm{eV}$. The fact that this value is near to the $3.40 \mathrm{eV}$ obtained from the red limit of photocurrent supports the hypothesis that the same mechanism is involved in both phenomena.

I thank I.C.I. and the British Petroleum Company for support in the course of research.

Department of Physical Chemistry,

M. HEYROVSKÝ

University of Cambridge.

1 Barker, G. C., and Gard̄er, A. W.: papers presented at the fourteenth meeting of C.I.T.C.E. in Moscow (August 1963), and

2 Berg, H, and Schweiss, H., Electrochim. Acta, 9, 425 (1964).

${ }_{3}$ Heyrovsky, M., and Norrish, R. G. W., Nature, 200, 880 (1963).

${ }^{4}$ Reyror, D., Phys. Rev., 36, 738 (1930).

5 Dainton, F. S., and James D. G. L., Trans. Faraday Soc., 54, 649 (1958). 


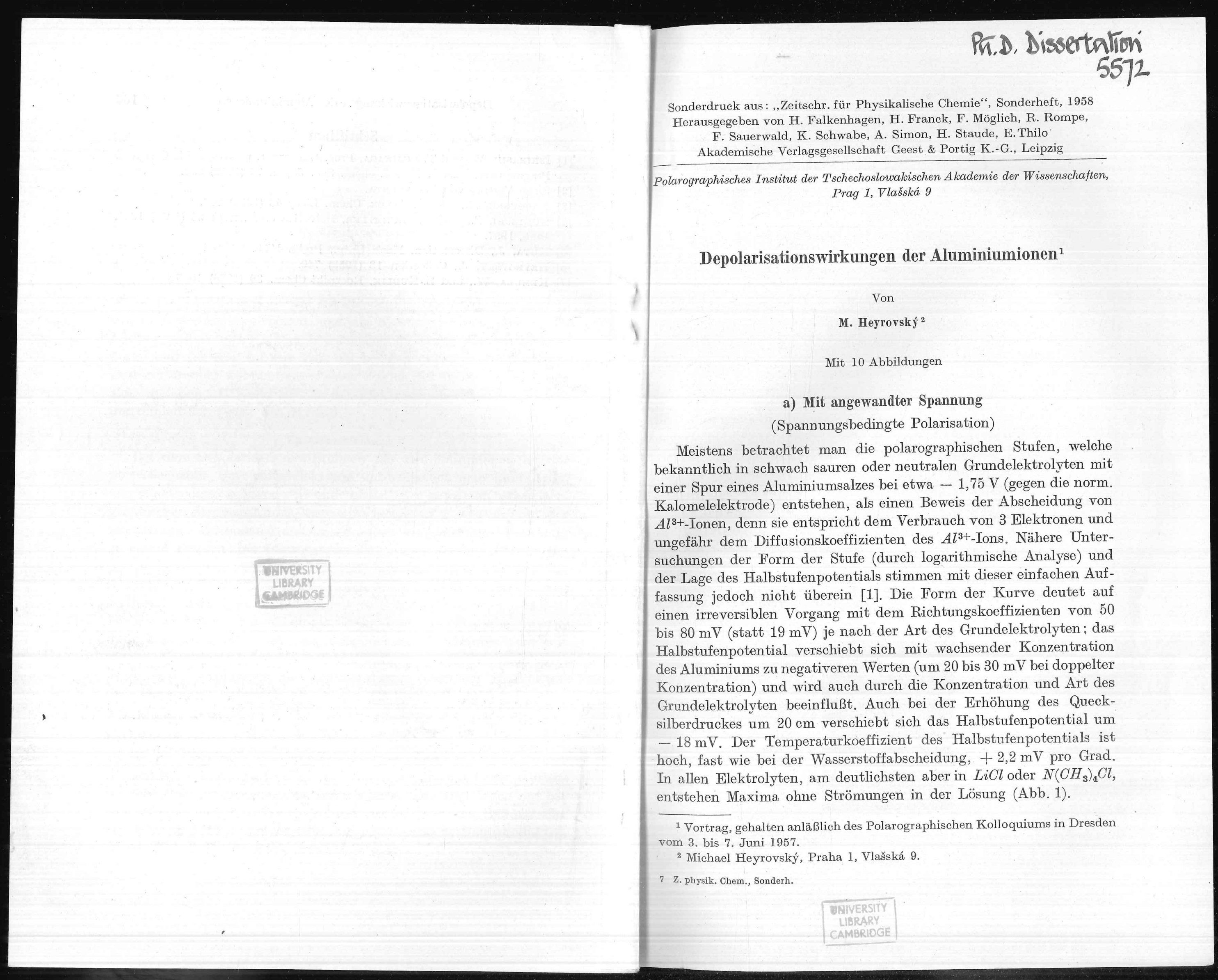




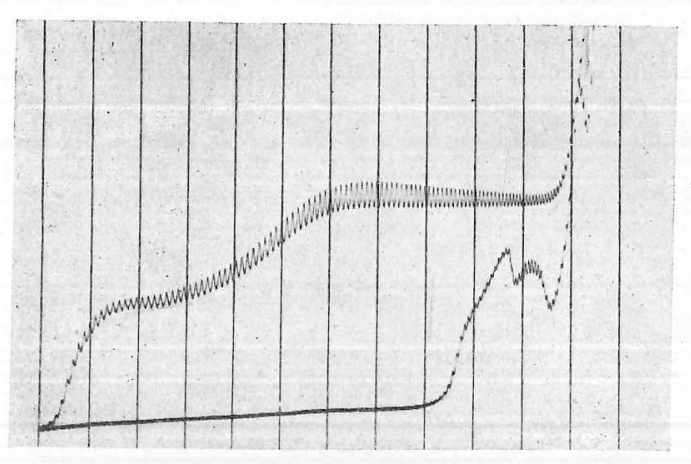

Abb. 1. Polarographische Stromspannungskurve von $3,85 \cdot 10^{-4} \mathrm{~m} \mathrm{KAl(SO_{4 } ) _ { 2 }}$ Stickstoffatmosphäre.

Die Stromspannungskurven auf dem Kathodenstrahloszillographen zeigen bei mäßiger Geschwindigkeit der Spannungssteigung an einem Tropfen (1 V pro sec) die üblichen Maxima (,,pealss") (Abb. 2), welche jedoch bei der rückgängigen Kurve wieder erscheinen, obzwar sie wegen gradueller Erschöpfung des Depolarisators versch winden sollten. Ein solches Verhalten zeigen nur Maxima der katalytischen Wasserstoffabscheidung (gemä $\beta$ V stoffabsch entstehen beim Depolarisationspotential keine anodischen Ströme. An

Das bisher erwiante Verhalten der polarographischen Kurven beweist eher eine völlig irreversible Abscheidung (wie z. B. die des

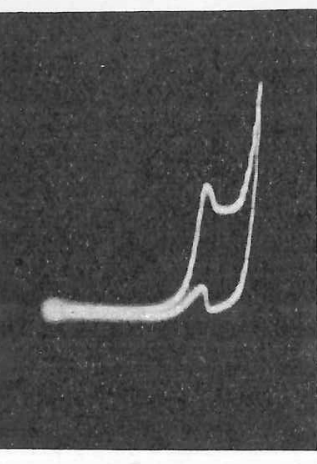

Abb. 2. Oszillographische Stromspannungskurven. Lösung $3,8 \cdot 10^{-3} \mathrm{~m} A l_{2}$ $\left(\mathrm{SO}_{4}\right)_{3}, 4 \mathrm{nLiCl}$, in $\mathrm{N}_{2}$; obere Kurve von 0 bis $-2 \mathrm{~V}$, untere von $\left(\mathrm{SO}_{4}\right)_{3}, 4$ n LiCl, in $\mathrm{N}_{2}$; obere
Depolarisationswirkungen der Aluminiumionen

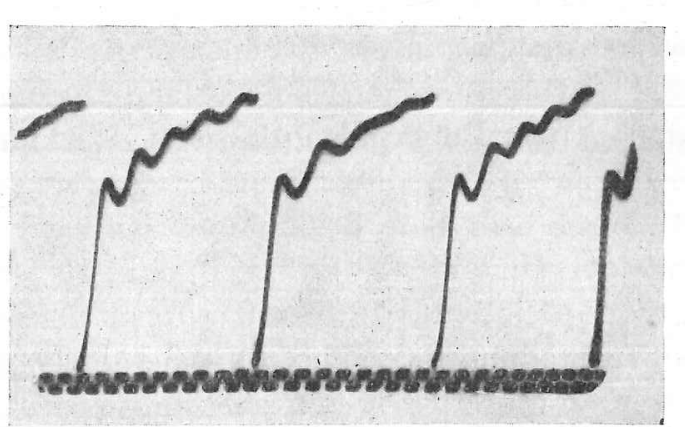

Abb. 3. i-t-Kurven beimhalben Grenzstrom von $9 \cdot 10^{-4} \mathrm{~m} K A l\left(S O_{4}\right)_{2}$ in $0,1 n$ LiC in $N_{2}$, bei $-1,74 \mathrm{~V}$. Die Zacken geben 0,31 sec an.

Wasserstoffs) als eine Aluminiumamalgambildung. Eine andere Anomalie zeigen auch die Strom-Zeit-Kurven des Diffusionsstromes der Aluminiumstufe Die Kurven (Abb. 3) sind gewellt, als ob ein Vorgang periodisch die elektrolytische A bscheidung stören würde. Tach langem periodisch Ka plla Kapillo

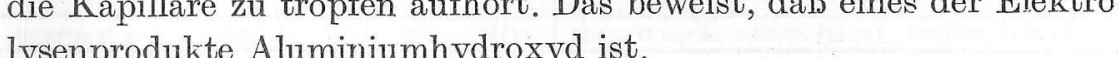

Ein anderes Merkmal einer Wasserstoffabscheidung ist das Verhalten der Aluminiumionen bei der Elektroreduktion organischer Verbindungen, wie Benzaldehyd, Azetophenon, Azobenzol, Benzil und vielen anderen. Wie RuETSCHT und Truempler [4] festgestellt haben,

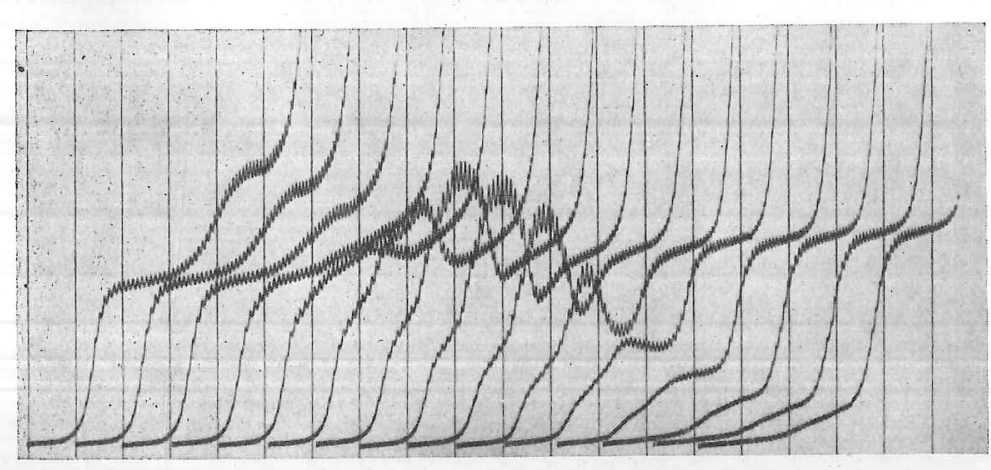

Alb. 4. Zu $5 \mathrm{ml} 1,85 \cdot 10^{-4} \mathrm{mp}$-Diäthylaminobenzaldehyd in $0,1 \mathrm{n} \mathrm{KCl}$ wurder je $0,1 \mathrm{ml} 10^{-3} \mathrm{~m} \mathrm{KAl}\left(\mathrm{SO}_{4}\right)_{2}$ in $N_{2}$ zugegeben. Anfang der Kurven bei 
geben Protondonatoren, wenn sie zu einer neutralen ungepufferten Lösung einer reduzierbaren organischen Verbindung zugefügt werden, eine Stufe bei positiven Potentialen. Dieselbe Wirkung geben auch Aluminiumionen, die sich in dieser Beziehung wie eine Säure verhalten (Abb. 4). Wenn man diese Wirkung nit jener der freien Wasserstoffionen vergleicht, findet man, da $\beta$, B eine $10^{-3}$-m-AluminiumAlaun-Lösung vom pH-Wert 4,12 dieselbe depolarisierende Wirkung auf organische Verbindungen ausübt wie eine $10^{-3}-m$-Schwefelsäure von $\mathrm{pH}$ 2,8. Dagegen gibt $10^{-4}-m$-Schwefelsäure von $\mathrm{pH}$ 4,05 (welche fast den gleichen $\mathrm{pH}$-Wert wie die $10^{-3}-m$-Alaunlösung hat) keine Stufe. Es kommt hier also nicht auf den potentiometrischen $\mathrm{pH}$-Wert sondern auf die Anzahl der Protondonatoren an. Durch Berechnuns nach Ruetscit und Truenrpler findet man, daß ein $A l^{3+}-$ Ion der organischen Verbindung drei Protonen zur Verfügung stellt. Auch die katalytische Herabsetzung der Wasserstoffüberspannung durch organische Verbindungen, welche ein tertiäres oder heterocyclisches Stickstoffatom enthalten, wie Phenazinfarbstoffe und Arofarbstoffe (z. B. Phenosafranin Safranin, Methylenblau, Methyorane, Tropaeclin), wird in einer 3 hnliche Weise sowohl durch freie Was Tropaeclin), wass instoffWird einer dou Wird eine deutralen Formaldehydlosung eine Aluminiumlösung zugefügt, so entsteht beim Potential - 1,2 eine Stufe, die zu einem kinetisch beschrankten Grenzstrome wäehst. Bine alhniche stufe bei $-1,2 \mathrm{~V}$ erhält man auch, wenn zur Aldehydlösung Essigsäure zuefügt wird

Aus dem erwähnten Verhalten der Aluminiumionen bei Depolarisationen organischer Verbindungen und auch in verschiedenen Elektro-

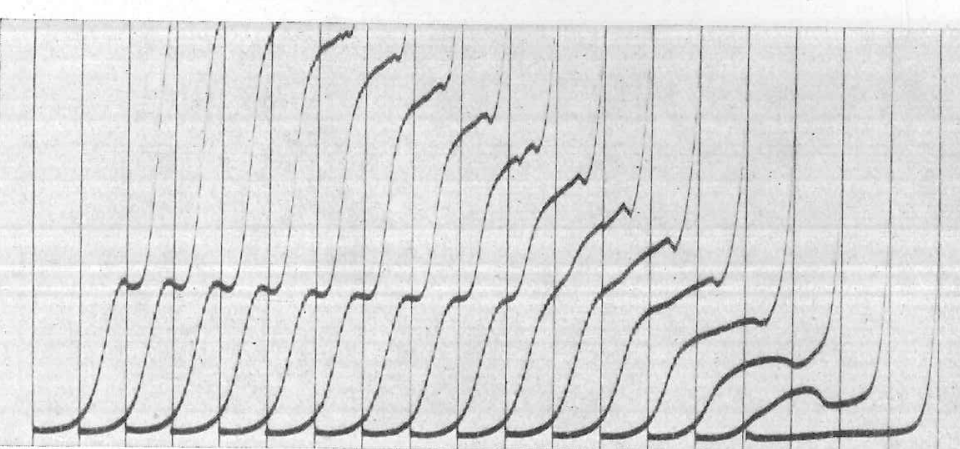

Abb. 5. Zu $5 \mathrm{ml} 2 \cdot 10^{-4} \mathrm{~m}$ Phenosafranin in $0,1 \mathrm{~m} \mathrm{KCl}$ wurden je $0,1 \mathrm{ml}$

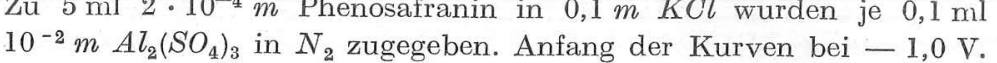

lyten findet man Analogien mit dem Verhalten der Wasserstoffionen lyten finet mastionen in schwachen Sacen. Aquoionen, wie von Beyllim und Thonim, polarographisch als Protonendona Wasserhülle so stark polarisiert sein, daß drei Protonen ionogen gehalten werden und zur elektrolytischen Wasserstoffabscheidung führen. Die Elektrodenreaktion des Aluminiumions wäre demnach $\mathrm{Al}\left(\mathrm{H}_{2} \mathrm{O}\right)_{6}{ }^{3+}+3 e \rightarrow \mathrm{Al}(\mathrm{OH})_{3}+3 \mathrm{H}_{2} \mathrm{O}+3 \mathrm{H}$.

Ein charakteristisches Verhalten bei der Depolarisation durch in an der derch den Al-Ton king an einem Toplen nung periollsoch Frequenz vellaut. VALwa hat mit sein spannung nachgewiesen, daß an dor crsten Kurve an neuen Tropfen die Stufe am grobten ist und dann, namentich bei grö̉eren Frequenzen, schnell auf Null abfallt (Abb. 6). Bei Frequenzen über 20 gibt es überhaupt keine Depolarisationserscheinung der Aluminiumionen Offenbar sind die an einer konstanten Klektrodenoberfläche vorhandenen Protonendonatoren bald erschöpft und bilden sich nur langsam aus den zudiffundierenden Aluminium-Aquokomplexen. Die durch die angelegte Spannung erhaltenen Stromspannungskurven, also die polarographischen Kurven der Aluminiumlösung, zeigen nur eine Wasserstoffabscheidung an.

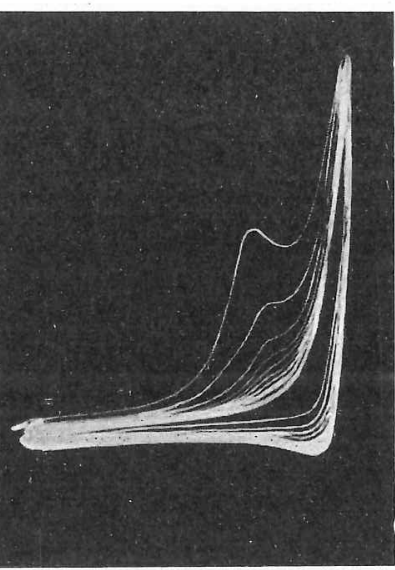

Abb. 6. Stromspannungskurven mit dem Kathodenstrahlpolarographen Stromspannungskurven mit dem Kathodenstrahl polarographen
2. $10^{-3} \mathrm{mangszyklen}$ an einem Tropfen, Frequenz $25 \mathrm{~Hz}$. Lösung 
b) Mit angewandtem Strom

(Strombedingte Polarisation)

Völlig verschieden sind die Ergebnisse, wenn man die Elektrolyse der Spuren von Aluminiumsalzen enthaltenden Elektrolytlösung mit konstantem Strom verfolgt. Mittels seiner Wechselstromoszillographie hat J. HEYROVSKY [6] nachgewiesen, daß sich nur bei einer ziemlich großen Stromdichte (10 $10^{-4}$ bis $10^{-3}$ A auf die Tropfenoberflache) eine Depolarisationserscheinung der Aluminiumionen zeigt (Abb. 8), und

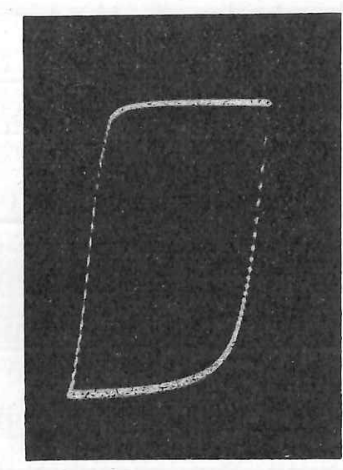

Abb. 7a. Oszillographische Potential-

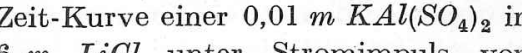

$2,5 \cdot 10^{-6} \mathrm{~A}, 1 / 6 \mathrm{~Hz}$.

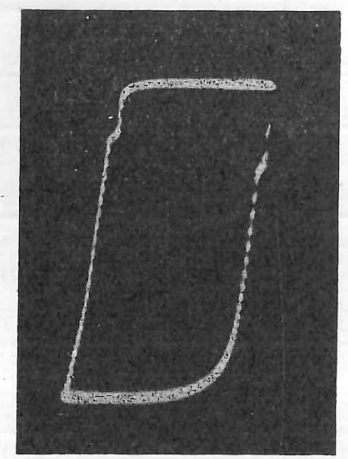

bb. 7b. Oszillographische PotentialZeit-Kurve derselben Lösung wie in Stromimpulsen $2 \cdot 10^{-4} \mathrm{~A},{ }_{16}^{1 / 6} \mathrm{~Hz}$.

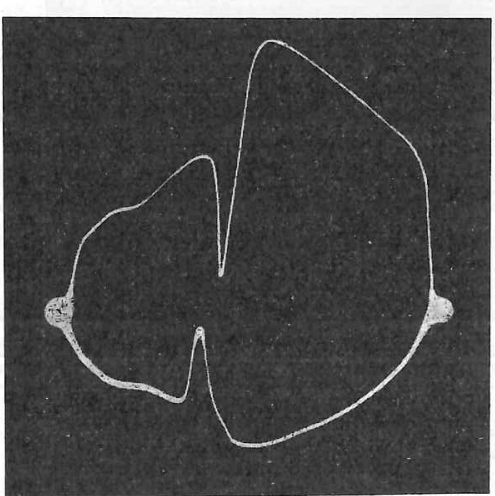

Abb. 8. Wechselstromoszillogramm $\frac{d V}{d t}-V, 50 \mathrm{~Hz}$, der Lösung $5 \cdot 10^{-3} \mathrm{~m}$ $\mathrm{Al}^{3+}$ in $1 \mathrm{~m} \mathrm{LiCl}, \mathrm{i}=0,4 \mathrm{~mA}$, nach 5 Sekunden Einwirkung. zwar je nach der Stromdichte, bei positiveren Potentialen zwischen $-1,7$ bis $-1,2 \mathrm{~V}$, aber nur dann, wenn in der Lösung neben den Aluminimionen auch Lithiumionen anwesend sind. Kewoua dn KUBLIK [7] haben diese spezifische Reaktion am langsamen Tropfen nachgepruft und gefunden, daß sich bei langem kin wirken des Wechelstromes die oszillographischen kinschnitte an den Ableitungskurven allmählich vertiefen und dadurch viel empfindlicher gegen Spuren (bis $10^{-3} \mathrm{~m}$ ) entweder von Aluminium- oder von Lithiumionen werden.

In der vorliegenden Arbeit wurde ein an einem kurzen PlatinTher elektrolytisch erzeugt und als polaricte benutzt, da er stärkere Ströme als die an der Kapillore hanonde Tropfelektrode verträgt, ohne abzufallen. Es der Kailla kleichstromes der Stärke wurden 2,5 - 10 bis 2 10 A angewendet. Das Potential wird am Schirm des Oszillographen als Potential'Zeitlure (V-G) veranschaulicht. Solange die Sthorktion steigt, ist auf der $V$-t-Kurve keine Verzogerang in Potentian zu beobachten (Abb. 7a, b). Nach 3 Minuten langom Impulsen mit der 100tachen Stromstarke $\left(2 \cdot 10^{-4} \mathrm{~A}\right)$ wird sowohl eine kathodische als auch eine anodische Verzogerng des Depolansationpotentials sichtbar. Sie verbleibt auch, wenn die Stromstarke auf den ursprünglichen Wert $\left(2,5 \cdot 10^{-6} \mathrm{~A}\right)$ herabgesetzt wird. Wenn nun auf den anhaftenden Tropfen die Elektrolyse mit dem Wechselstrom einwirkt und am Leuchtschirm die Abhängigkeit $\frac{d V}{d t}-V$ aufleuchtet, kommen die bekannten, sich mit der Zeitdauer vertiefenden Einschnitte zum Vorschein (Abb. 8).

Diese nur bei gesteigerter Stromdichte auftretende Depolarisation erklärt J. HeYrovsky [6] durch Bildung des $\mathrm{LiAlH}_{4}$-Komplexes. Die große Stromdichte sei der Bildung von $H^{-}$-Ionen güstig, da sich dabei die Doppelschicht sehr schnell auflädt und die zur Kathode zugeführten Elektronen in die wäßrige Schicht eindringen und mit Wasser die Anionen $\mathrm{H}^{-}$bilden; in Gegenwart von viel $\mathrm{Li}^{+}$- und $\mathrm{Al}^{3+}$ Ionen vereinigen sich diese. Kationen mit den $H^{-}$-Ionen zum Komplex LiAl füher als sie mit Wasserstoffionen zu $H_{2}$ reagieren können,

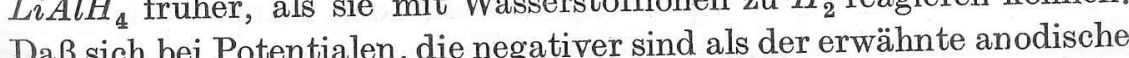
Daß sich bei Poter Depolarisations der 
wesenheit des Films zeigt sich durch eine Verminderung der Einschnitte von $\mathrm{H}^{+}, \mathrm{Mn}^{2+}, \mathrm{Fe}^{2+}$ und $\mathrm{Zn}^{2+}$, wenn diese Ionen bei Anwesenheit von $A l^{3+}$-Ionen dem Lithium enthaltenden Elektrolyten zugefügt werden.

Der elektrolytische Vorgang

$$
\mathrm{Li}^{+}+\mathrm{Al}^{+++}+4 \mathrm{H}^{+}+8 e \rightleftarrows \mathrm{LiAlH}_{4}
$$

oder die durch $\mathrm{Li}^{+}$- und $A l^{3+}$-Ionen katalysierte Reaktion

$$
4 \mathrm{H}^{+}+8 \mathrm{e} \rightleftarrows 4 \mathrm{H}^{-}
$$

verlaufen sehr schnell, wie aus den scharfen Einschnitten der $\frac{d V}{d t}-t$ Kurve (Abb. 9) und deren Verbleiben bis zu Frequenzen von $1500 \mathrm{~Hz}$ hervorgeht. Wie oben angegeben, ändert sich das Depolarisationspotential dieses Vorganges gemäß der Stromdichte, und zwar liegt es bei kleineren Ladungsströmen am kathodischen Ast bei - 1,70 V und am anodischen Ast bei - 1,40 V. Bei großer Stromdichte $\left(10^{-3} \mathrm{~A}\right)$ wird das Depolarisationspotential bis um $500 \mathrm{mV}$ positiver, also sehr

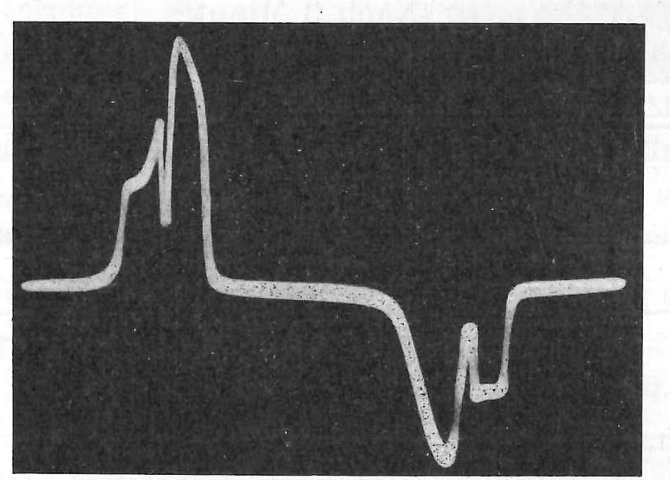

Abb. 9. Wechselstromoszillogramm $\frac{d V}{d t}-t, 50 \mathrm{~Hz}$, der Lösung $5 \cdot 10^{-3} \mathrm{~m}$ $\mathrm{Al}^{3+}$ in $1 \mathrm{~m} \mathrm{Li}_{2} \mathrm{SO}_{4}$

vom Abscheidungspotential der polarographischen Stromspannungskurven mit angelegter Spannung verschieden. Durch verlängerte Polarisation mittels stärkeren Wechselstromes (über $10^{-3} \mathrm{~A}$ ) am stabil befestigten Tropfen wird die Empfindlichkeit des L̈rscheinens der Lithium-Aluminium-Einschnitte so weit gesteigert, daß sie noch in einem Gemisch von $10^{-6} \mathrm{~m} \mathrm{Al} l^{3+}$ mit $0,1 \mathrm{~m} \mathrm{Li}^{+}$oder $0,1 \mathrm{~m} \mathrm{Al} l^{3+}$ in

Anwesenheit von $10^{-6} \mathrm{~m} \mathrm{Li}^{+}$bemerkbar sind. Die Konstanz des Konzentrationsprodukte

$$
\left[A l^{3+}\right] \cdot\left[L i^{+}\right]=10^{-7}
$$

deutet auf eine Verbindung gleicher Anzahl von $A 7^{3+}$ - und $L i^{+}$-Ionen hin. Daß nur die Höhe des Ladungsstromes fürdie Lithium-AluminiumReaktion entscheidend ist, zeigt ein Versuch, bei dem der stabile Tropfen zuerst einer Wechselstromelektrolyse mit großer Stromdichte und sofort nachher der spannungsbedingten polarographischen Elektrolyse mit auf- und absteigender Spannung unterworfen wird. Die erste dieser Stromspannungskurven zeigt sowohl die kathodische und anodische Lithium-Aluminium-Wirkung der Wechselstromkurven als auch den tathodischen Stromanstieg der polarographischen Depolariauch (a) der Waserstion sation (also der Waser auf- und abstigen dieser Wirkung und verschiebt sich zu negativeren Potentialen, um in den gewöh überzugehen.

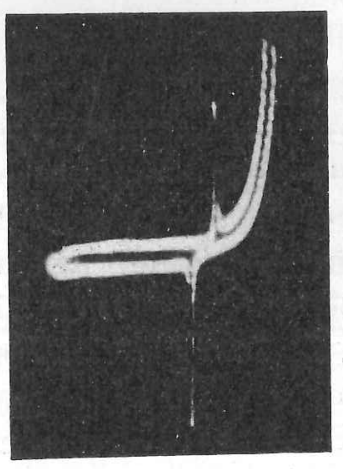

Abb. 10. Die am Kathodenstrahlpolarographen erhaltene Stromspannungskurve an einem stabilen Tropfen, der vorher durch Wechselstrom kurve an einem stabilen Tropten, der vorher durch
von $3 \cdot 10^{-4} \mathrm{~A}$ polarisiert wurde. Lösung $3,8 \cdot 10^{-3} \mathrm{mAl} \mathrm{Al}_{2}\left(\mathrm{SO}_{4}\right)_{3}$ in
in (obere Kurve) und zurück (untere Kurve).

Es gibt also an der Quecksilberelektrode zwei verschiedenartige Depolarisationsvorgänge der Aluminiumionen, je nachdem, ob die Elektrolyse unter Einwirkung der angewandten Spannung oder des angewandten Stromes verläuft. Im ersten Falle kommt es zur Wasserstoffabscheidung, im zweiten - und zwar nur bei Anwesenheit von 
Lithiumionen und bei großer Stromdichte - bildet sich wahrscheinich Lithium-Aluminium-Hydrid.

Es erübrigt sich zu erklären, warum sich bei langer Anwendung des Wechselstromes die Lithium-Aluminium-Einschnitte an den $\mathrm{Ab}$ leitungskurven vertiefen und dann, nach einem viele Minuten langen Unterbrechen der Elektrolyse, wieder beim Einschalten des Wechselstromes tiefe Einschnitte erscheinen (KEMULA-KUBLIK [7]). Während der strombedingten Polarisation kommt es bei negativen Potentialen zur Bildung und Adsorption von $\mathrm{LiAlH}_{4}$ und zur Diffusion der $\mathrm{Al}^{3+}$ - und $\mathrm{Li}^{+}$-Ionen an die Elektrodenoberfläche. Bei positivem Potential zerfällt das Hydrid, und die Kationen diffundieren in die Lösung, jedoch unter einem beträchtlich kleineren Konzentrationsabfall und für eine kürzere Zeit als bei den negativen Potentialen. Dadurch werden während eines jeden Zyklus des Wechselstromes die aktiven Ionen, $A l^{3+}$ und $\mathrm{Li}^{+}$, an der Elektrodenoberfläche angehäuft und bilden dann eher das Hydrid.

\section{Zusammenfassung}

Bei den Depolarisationswirkungen der Aluminiumionen an der polarisierbaren Quecksilberelektrode unterscheidet man zwei Arten von Elektrodenvorgängen: die eine verläuft bei gewöhnlichen polarographischen Stromspannungskurven mit angewandter Spannung oder mittels eines Kathodenstrahlpolarographen bei steigender Spannung an einem Tropfen. Die polarographische Analyse solcher Kurven, die mit angewandter Spannung ermittelt werden, zeigt, da $\beta$ sich die Aluminiumionen als Protonendonatoren verhalten und nur zur Wasserstoffabscheidung führen, und zwar beim Potential von etwa - 1,7V. Die zweite Art, die strombedingte Elektrolyse, besteht in der Anwendung eines definierten Stromes, entweder mit lonstonten oder mit

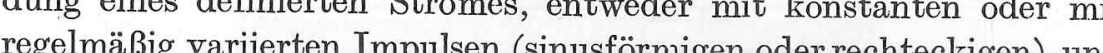
in der osvillographe, un des Potentials, entwange Ableitungskurven $\frac{d V}{d t}-t, \frac{d V}{d t}-V$. Mit dieser Einrichtung erhält man kathodische und anodische Einschnitte je nach der Stromdichte von $10^{-4} \mathrm{~A}$ pro Oberfläche des Tropfens aufwärts, und zwar unter großen Stromdichten bei $-1,2 \mathrm{~V}$, die sich beim Herabsetzen der Stromdichte bis zu $-1,7 \mathrm{~V}$ verschieben. Diese Depolarisationen entstehen nur be Anwesenheit von Lithiumionen und deuten auf die Bildung des Hydrids $\mathrm{Li}^{+}\left[\mathrm{AlH} \mathrm{H}^{-} \mathrm{hin}, \mathrm{welh}\right.$. an der Elektrodenoberfläche adsorbiert wird.

Sehrifttum

T. FUJINAGA, Proc. I. internat. polarographic Congress,

[3] KATOTSEK, M., und M. RALEE, Chem. Listy 48 (1954) 808.

[4] RURTSCHT, P., und G. TruEEMPIERR, Helvetica chim. Acta 35 (1952) 1021, $1486,1957$.

[5] KutA, J., Dissertation, Karls Univ., Praha 1950

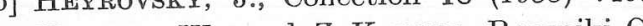

30 (1956) 1005 


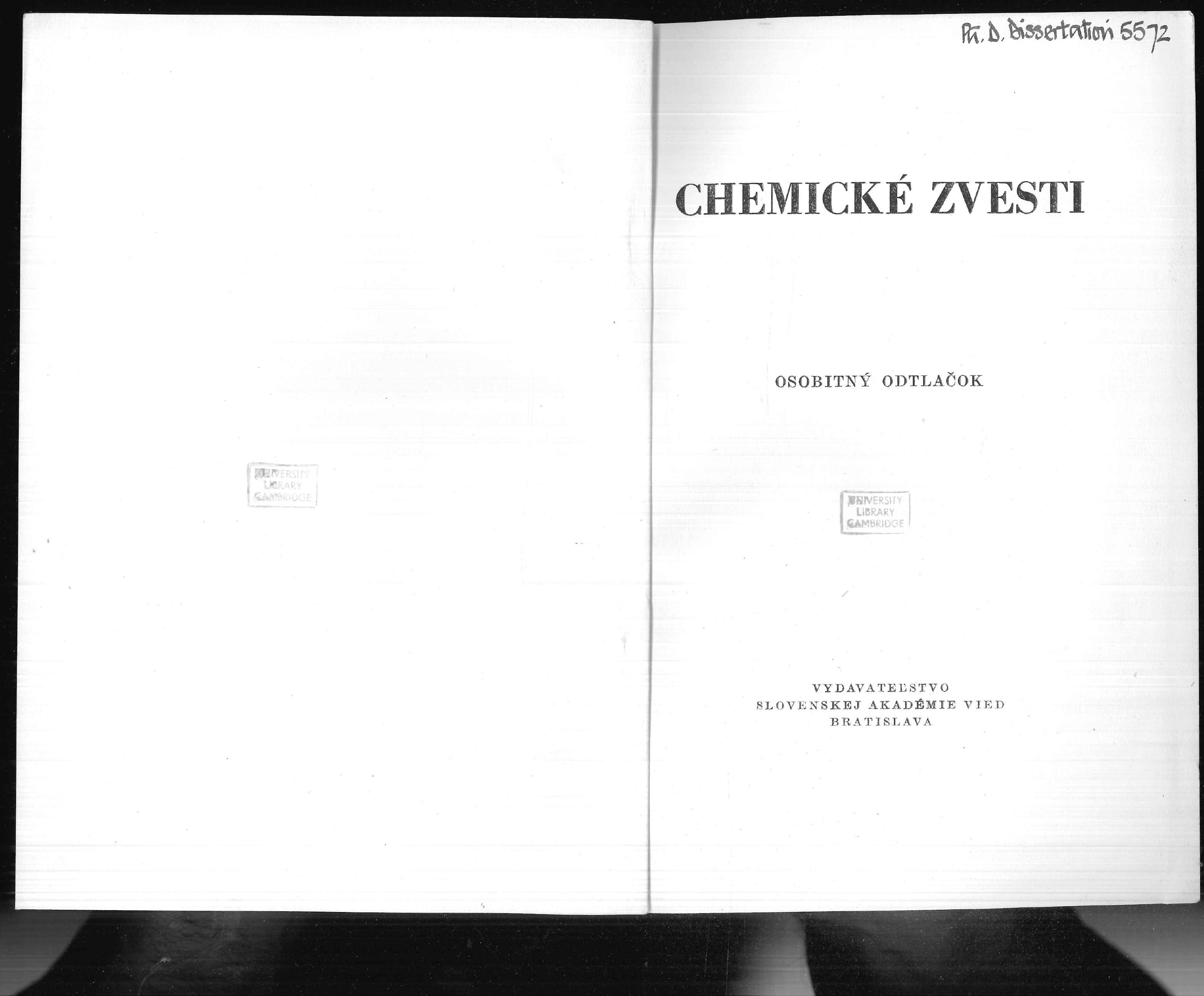




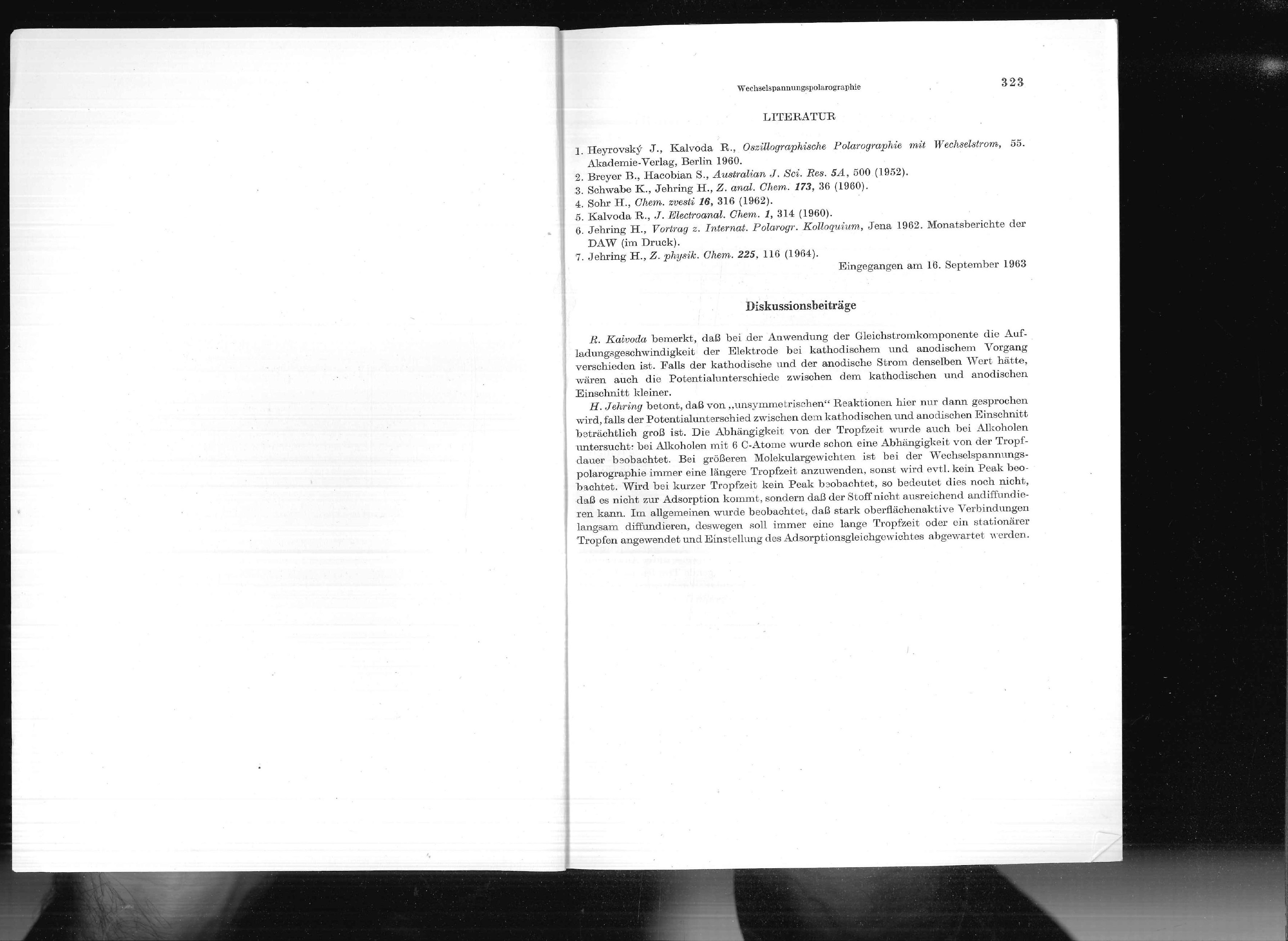


Zu den elektrolytischen Reaktionen von Mangan(II)-Ionen in Anwesenheit von Sauerstoff

$$
\text { XI. HEYROVSKÝ }
$$
Poïarographisches Institut, Tschechoslowakische Akademie der Wissensehaften
Praha

Ess wurden die elektrolytischen Reaktionen von sauerstoffhaltigen Man an(II)-Lösungæn mit Hilfe der oszillographischen Polarographie und anderen dung von Manganhydroxid auf der Elektrodenoberfläche erklärt, dies BilReduktion zum Metall oder der Oxydation zu Mangan(III)-hydroxid mit nachfolgender Rückredultion unterliegt.

Als einer der Vorteile der oszillographischen Polarographie mit Wechselstrom gegenüber der klassischen Polarographie wird oft die Tatsache betrachtet, daß der Sauerstoff keinen Einfluß auf die Messungen ausübt. Es sind aber doch einige Beispiele bekannt, bei denen die Gestalt der Polarisationskurven durch die Sauerstoffreduktion beträchtlich beeinflußt wird. Sehr deutlich ist dieser Effekt im Falle der Redultion des zweiwertigen Mangans in neutralen ungepufferten Lösungen zu beobachten. Das oszillographische Verhalten der Mangan(II)-Ionen in sauerstoffhaltigen Lösungen ist schon seit langem bekannt $[1,2]$, bisher fehlt aber eine befriedigende Erklärung der beteiligten Prozesse. Die vorliegende Arbeit stellt einen Versuch dar, eine derartige Prozesse. Die vorlieg

\section{Experimenteller Tei}

Alle oszillopolarogeaphischen Messungen wurden mit einem polarographischen Oszilloskop P-4F (Konstruktion nach Dr. Vogel) durchgeführt teilweise unter Anwendung enes Adapteurs für spannungsbedingte Polarisation. Der hängende Tropfen nach Vogel
wurde in Verbindung mit dem Polarecord Metrohm benutzt. Zur Registrierung der Kurven mit Umschaltung des Potentials diente ein Polarograph V 301, der mit einem elektronischen Umschalter nach Novák und Rálek gekoppelt war.

Die Lösungen wurden in einer einfachen elektrolytischen Zelle mit Bodenquecksilber als Bezugselektrode und in dem Gefäß nach Kalousek mit gesonderter gesättigter Kalomelelektrode unterssieht. Alle benulaten chemikalien ( $\mathrm{LiCl}, \mathrm{KCl}, \mathrm{MnCl}_{2}, \mathrm{~K}_{2} \mathrm{SO}_{4}, \mathrm{Na}_{2} \mathrm{SO}_{4}$

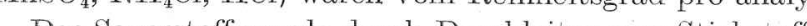

Ergebnisse und Diskussion

In der oszillographischen Polarographie mit Wechselstrom gibt zweiwertiges Mangan, wie schon früher beschrieben wurde, in verdünnten, nicht- entlüfteten Lösungen von Alkalimetallsalzen eine charakteristische Kurve deren Form stark von dem angewandten Potentialbereich abhängt. Wird die Quecksilbertropfelektrode bis zu den beiden extremen Grenzpotentialen polarisiert, so entstehen auf der $\mathrm{d} E / \mathrm{d} t=\mathrm{f}(E)$ Kurve zwei kathodische Einchnitte von $Q^{*} 0,78$ und 0,88 (in $1 \mathrm{M}-\mathrm{LiCl}$ ), die sich mit steigender Mangankonzentration vertiefen (Abb. 1 $a$ ). Ist die Mangankonzentration kleiner al die des Sauerstoffes, so erseheint nur der negativere Einschnitt (Abb. 2).

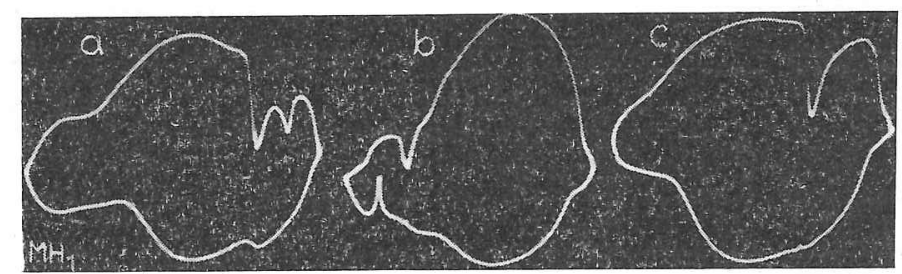

Abb. 1. $2 \cdot 10^{-3} \mathrm{M}^{-}-\mathrm{MnCl}_{2}$ in $0,5 \mathrm{M}-\mathrm{LiCl}$ bei Luftzutritt; $i=0,2 \mathrm{~mA}$.

a) Ele auf die beiden extremen Grenzpotentiale polarisiert; $b$ ) das negative Grenzpotential erreicht nicht den Wert des zweiten negativen Einschnittes; $c$ ) das positive Grenzpotential wird negativer als $0,3 \mathrm{~V}$ (auf das Bodenquecksilber bezogen).

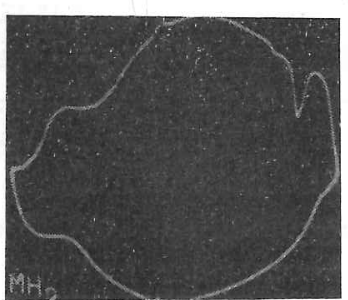

$A b b .2 .5 \cdot 10^{-4} \mathrm{M}-\mathrm{MnCl}_{2}$ in $0,5 \mathrm{M}-\mathrm{LiC}$ bei Luftzutritt; $i=0,2 \mathrm{~mA}$. Die Elektrode im vollen Potentialbereich polarisiert.

Wenn das negative Grenzpotential der Kurve nicht den Wert des zweite kathodischen Einschnittes erreicht, entwickeln sich bei positiven Potentialen zwei einander gegenüber liegende Einschnitte (Abb. 1b), ein anodischer $(Q 0,12)$ und ein kathodischer $(Q 0,17$, auf die vollentwickelte Kurve in $1 \mathrm{~m}-\mathrm{LiC}$ bezogen). Wird dagegen das positive Grenzpotential der Kurve negativer al etwa $Q 0,1$, so verschwindet der zweite negative kathodische Einschnitt und auf der Kurve verbleibt nur der von $Q 0,78(\mathrm{Abb}, 1 \mathrm{lc})$. Völlig analog sind die auf dor Kan oszillow (Abb. $3 a-c)$.
Elektrode durch vorgegebene dreiecklormige Kippspannang polatisiert wird

Entfernung des Sauerstoffes aus der Tösung verschwinden die beiden positiven Einschnitte und der zweite negative kathodische. Einen gleichen [10]. 
Effekt hat die Zugabe kleiner Mengen von Säuren oder Ammoniumsalzen (Abb. 4). Auch in Pufferlösungen erscheint auf der oszillographischen Kurv nur der erste negative kathodische Einschnitt. Die drei Einschnitte fehlen auf der Kurve, auch wenn die Lösung mit der Quecksilberstrahlelektrode elektro lysiert wird.

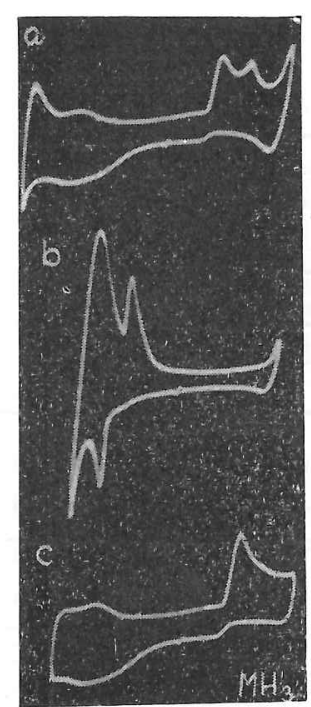

Abb. 3. $2 \cdot 10^{-3} \mathrm{M}^{-\mathrm{MnCl}_{2}}$ in $0,5 \mathrm{M}-\mathrm{LiCl}$ bei Luftzutritt. sannung polarisiert, Frequenz $50 \mathrm{~Hz}, \mathrm{~d} E / \mathrm{d} t=200 \mathrm{~V} / \mathrm{s} ; a$, $c-$ wie bei Abb. 1.

Die Tiefe der beiden positiven und des zweiten negativen Einschnittes ist gegenüber der Ionenstärke der Grundlösung empfindlich. In Chloriden von Einschnitte nicht mehr zu beobachten. Bei Sulfatkonzentration von rund 0,5 M entsteht bei positiven Potentialen nur der anodische Einschnitt; der gegenüberliegende kathodische erscheint erst nach dem Verdünnen. Auch die Zugabe lleiner Tengen von zwei- und dreiwertigen Kationen vermindert die drei Einschnitte.

Der erste negative kathodische Einschnitt entspricht ohne Zweifel der elektroDer ly wisch the Einschitt entsteht in allon Lösungen, die Ma Potential stimmt mit dom pola graphischen Halo schreiben:

$$
\mathrm{Mn}^{2+} \mathrm{aq}+2 \mathrm{e} \rightarrow \mathrm{Mn}(\mathrm{Hg}) .
$$

Dieser Prozess ist teilweise reversibel, wie aus den Abbildungen $1 a, 3 a$ und $3 c$ zu sehen ist. Die Reversibilität der Auflösung des Manganamalgams hängt stark von der Zusammensetzung der Lösung und von den anderen

rsuchsbedingungen ab. Wie W. Kemula und. Z. Galus [3] gezeigt haben,

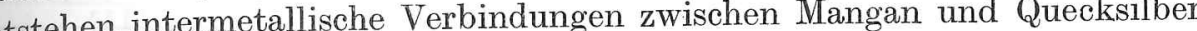
Tur Apfösung des Mangans aus seinem Amalgam kommt es bei drei

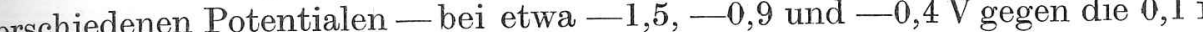
Tin Anzeichen der Auflösung bei $-0,9 \mathrm{~V}$ ist auf den Kapazitätsmaximums des Grundaszllogaphischen Kur elektrolych Gleichung:

$$
\mathrm{Mn}(\mathrm{Hg}) \rightarrow \mathrm{Mn}^{2+} \mathrm{aq}+2 \mathrm{e} .
$$

Der zweite negative kathodische Einschnitt begleitet immer den ReduktionsDer and Sarestoflonzer Sauenstoflkonzers von Sauren, A Veris führte uns zur Vermutung, daß es sich hior un dis Re

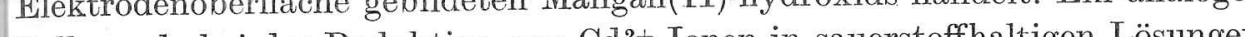
Fall wurde bei der Reduktion von $\mathrm{Cd}^{2+}$-Ionen in sauerstofthalligen Lösungen

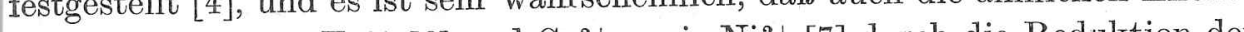
bei $\mathrm{Zn}^{2+}, \mathrm{Pb}^{2+}[5], \mathrm{Fe}^{2+}[6]$ und $\mathrm{Co}^{2+}$ sowie $\mathrm{Ni}{ }^{2+}[7]$ durch die Reduktion de entsprechenden Hydroxide zu erkaren sind.

Bei kleinen Mangankonzentrationen werden alle Mangan-Ionen an de Elektrodenoberfläche durch die $\mathrm{OH}^{-}$-Ionen gefällt und das gebildete Manan(II)-hydroxid wird bei dem Potential des negativeren Einschnittes reduziert (Abb. 2). Die höhere Konzentration der Grundelektrolyten wirkt ent veder durch Komplexierung oder Peptisierung gegen die Fallung des Manganydroxids auf der Quecksilberoberfläche. In der gleichen Weise erklärte A. Laitinen [11] den Einfluß der Konzentration des Grundelektrolyten uf die Bildung von Kobalt(II)-hydroxid an der Tropfelektrode.

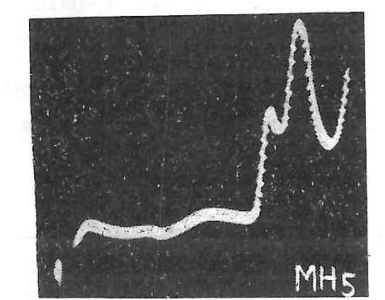

Die oszillographischen Stromspannungskurven mit einzelnen linearen Spannungsimpulsen (single-sweep) haben gezeigt, daß nach den beiden Sauerstoffreduktionsstufen und nach dem Strommaximum der $\mathrm{Mn}^{2+}$-Reduktion eine zweite Stromspitze erscheint (Abb. 5), die außer durch die oben erwähnten Reagenzien auch durch einen kleinen Gelatinezusatz unterdrückt werden. 
kann. Die Gelatine verhindert offensichtlich die Bildung des Manganhydroxids an der Elektrodenoberfläche. H. A. Laitinen und Mitarbeiter [11] haben denselben Effekt bei Bildung des Filmes von Kobalt(II)-hydroxid auf der Quecksilbertropfelektrode beobachtet. Das Auftreten dieses zweiten Maximums ist nicht mit dem Erreichen eines bestimmten Potentials verbunden - die Stromspitze wird durch kein elektrolytisches Oxydationsprodukt hervorgerufen. Bei Wiederholung des Impulses auf der Oberfläche des hängenden Tropfens entsteht das zweite Maximum auf der Stromspannungskurve nur dann, wenn die Anfangsspannung kleiner als $0.3 \mathrm{~V}$ wird. Bei dem entspredann, wenn die Anfangsspannung kleiner als 0,3 menten dem Amalgam völlig in Lösung und die nachfolgenden Elektrodenprozesse laufen wieder auf der reinen Quecksilberoberfläche ab. Mit höherem Anfangswert der angelegten Spannung sieht man auf der wiederholten. Kurve, daß die
Sauerstoffreduktion stark vermindert ist. Infolgedessen werden die $\mathrm{OH}^{-}$-Ionen Sauerstoffreduktion stark vermindert ist. Infolgedessen werden die $\mathrm{OH}^{-}$-Ionen Bildung von Manganhydroxirl erzeugt und alle Mangan-Ionen werden nur in dem positiveren Strommaximum reduziert. Die Unterdrückung der Sauerstoffreduktion an der Oberfläche aus verdünntem Manganamalgam wurde Stromspannungskurven bestätigt; eine Erklärung dafür konnte jedoch nicht gefunden werden.

Einen indirekten Beweis für die Reduzierbarkeit des an der Elektrodenoberfläche sich bildenden Manganhydroxids bietet auch die klassische Polarographie. Die polarographische Reduktionsstufe der $\mathrm{Mn}^{2+}$-Ionen addiert sich genau zu den zwei Stufen der Sauerstoffreduktion, nur ist das Halbstufenpotential dieser Manganstufe um $20 \mathrm{mV}$ zu negativeren Werten gegen die Stufe in sauerstofffreier Lösung verschoben. Es kommt hier also nicht zur Bildung in sauerstofffreier Lösung verschoben. Es kommt hier also nicht zur Bildung der „latenten Ströme“" [8], was nur dadurch zu erklären ist, daß das in der
Diffusionsschicht gefällte Manganhydroxid an der Elektrode völlig reduziert Diffusionsschicht gefällte Manganhydroxid an der Elektrode völlig reduzier

Dem zweiten, negativen kathodischen Einschnitt auf der oszillographischen Kurve entspricht also aus den oben angeführten Gründen die Reaktion

$\mathrm{Mn}(\mathrm{OH})_{2}+2 \mathrm{e} \rightarrow \mathrm{Mn}(\mathrm{Hg})+2 \mathrm{OH}^{-}$

mit der vorgelagerten Bildung des Manganhydroxids:

$$
\begin{gathered}
\mathrm{O}_{2}+4 \mathrm{e}+2 \mathrm{H}_{2} \mathrm{O} \rightarrow 4 \mathrm{OH}^{-} \\
2 \mathrm{Mn}^{2+}+4 \mathrm{OH}^{-} \rightarrow 2 \mathrm{Mn}(\mathrm{OH})_{2},
\end{gathered}
$$

Diese Fällung des Hydroxids spielt sich teilweise in der Elektrodendoppel schicht ab, was den Einfluß der Ionenstärke der Grundlösung auf die oszillopolarographische Einschnitte erklärt.

Der anodische Einschnitt erscheint af der Kurve nur dann, wenn es nicht zur Reduktion des Mangan leibt also an der Tletrodenoberflihe unzerstört und kann während der olischen Phase orydient werden. Bei longsamer Polaistion deshën-

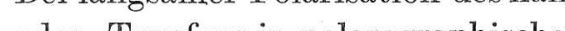

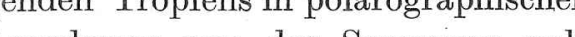
torch von der spannung null terter the und zuruck erscheint auf dem nodischen Ast der Stromspannungsurve eine Stromspitze, deren Potenial mit dem des oszillopolarograhischen Einschnittes übereinstimm (Abb. 6). Bei dem zweiten Polarisationszyklus entsteht bereits auch auf dem kathodischen Ast der Kurve ein scharfes Strommaximum bei demselben Potential wie der positive katho-

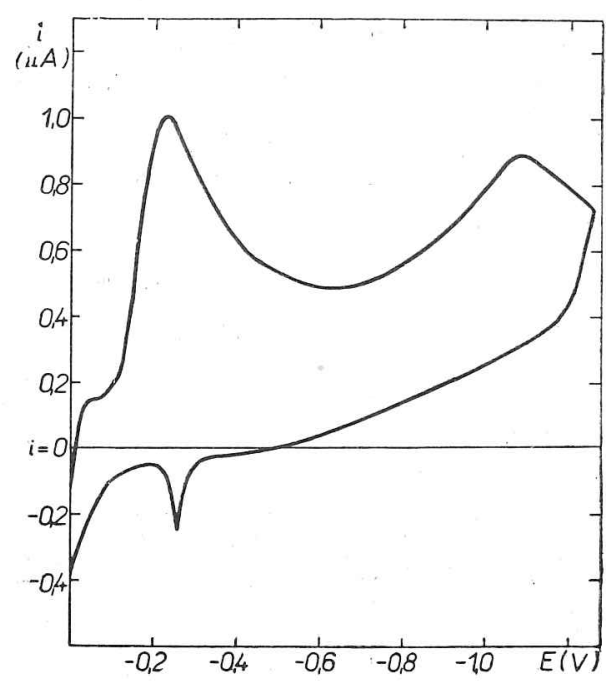

Abb. 6. $2 \cdot 10^{-3} \mathrm{M}-\mathrm{MnCl}_{2}$ in $0,1 \mathrm{M}-\mathrm{KCl}$ be Luftzutritt.

Der hängende Tropfen von null zu nega tiven Potentialen und zurück polarisier

dische Einschnitt. Dieser Effekt ist nicht zu beobachten, wenn das Potential der Elektrode nicht die zweite Reduktionsstufe des Sauerstoffes erreicht. Das anodische Maximum ist also der Oxydation des Produktes einer Re tion zwischen $\mathrm{OH}^{-}$- Ionen und $\mathrm{Mn}^{2+}$ - Ionen, nämlich des 7uzuch

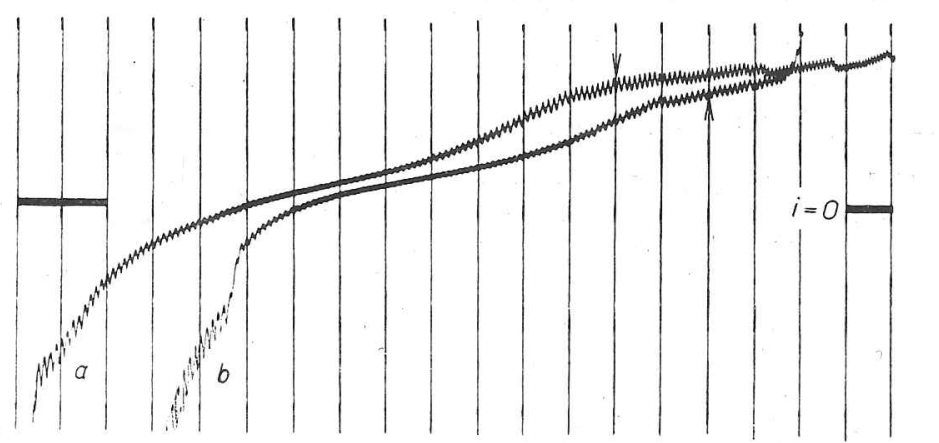

Abb. \%. Polarographische Kurven mit ungeschaltetem Potential nach Kalousek. a) $0,1 \mathrm{~N}-\mathrm{KCl}$ bei Luftzutritt; b) $2 \cdot 10^{-3} \mathrm{M}-\mathrm{MnCl}_{2}$ in $0,1 \mathrm{~N}-\mathrm{KCl}$ bei Luftzutritt, $100 \mathrm{mV} / \mathrm{Absz}$, on $0 \mathrm{~V}, S=1 / 40$; gegen Bodenquecksilber; Frequenz der Umschaltung $4 \mathrm{~Hz}$, Hilfspoverschoben. Galvanometer im Stromzweig des veränderlichen Potentials. 
sek bestätigt werden. Das bei dem Potential der zweiten Sauerstoffstufe in der Diffusionsschicht entstandene Manganhydroxid gibt bei Umschaltung eine liegt (Abb. 7). Für den mit dem anodischen Einschnitt verbundenen Prozes liegt (Abb. 7). Für den
läßt sich also schreiben:

$$
\begin{gathered}
\mathrm{Mn}(\mathrm{OH})_{2} \rightarrow \operatorname{Mn}(\mathrm{OH})_{2}^{+}+\mathrm{e}, \\
\mathrm{Mn}(\mathrm{OH})_{2}^{\frac{1}{2}}+\mathrm{Y}^{n-} \rightarrow \mathrm{Mn}(\mathrm{OH})_{2} \mathrm{Y}^{(n-1)^{-}} .
\end{gathered}
$$

In verdünnten Lösungen steht für $\mathrm{Y}^{n^{-}}$wahrscheinlich wieder $\mathrm{OH}^{-}$, in konzentrierteren Sulfatlösungen werden die Hydroxylionen gegen Sulfat-Ionen vertauscht.

Der positive kathodische Einschnitt gehört, wie aus dem obenangeführten folgt, der Rückreduktion des Mangan(III)-hydroxids zum Mangan(II)-hydroxid. In Sulfatlösungen, in denen die Bildung des Mangan(III)-hydroxids nach der Oxydation verhindert wird, tritt dieser Einsehnitt nicht auf

Bei Wiederholung der inzenen linearen Spannungimpulse aif dem hänBei Wiederholung der einzelnen linearen Spannungsimpulse auf dem hängenden Tropfent der Manganredultion erreicht, auf der Stromspannungskurve bei den Potential des oszillopolarographischen Kinsohites eine Spitze, die offenbar ach dieser Reduktion entspricht. In alteren Losungen, in denen die Existenz von Hydrolyseprodukten, unter anderem auch des Mangan(HI)-hydroxids, anzunehmen ist, entsteht diese Spitze schon auf der ersten Kurve (Abb. 8), Für den positiven kathodischen Einschnitt gilt also die umgekehrte Reaktio wie für den anodischen:

$\mathrm{Mn}(\mathrm{OH})_{3}+\mathrm{e} \rightarrow \mathrm{Mn}(\mathrm{OH})_{2}+\mathrm{OH}^{-}$. Nach den Berechnungen von W. M. Latimer [9] ist für die Reaktion

$\mathrm{Mn}(\mathrm{OH})_{2}+\mathrm{OH}^{-} \rightleftarrows \mathrm{Mn}(\mathrm{OH})_{3}+\mathrm{e}$

das Potential von etwa $-0,23 \mathrm{~V}$ gegen die $0,1 \mathrm{M}$-KCl-Elektrode $\mathrm{z}$

Abb. 8. $2 \cdot 10^{-3} \mathrm{M}-\mathrm{MnCl}_{2}$ in $0,1 \mathrm{M}-\mathrm{KCl}$, Kurve mit dem hängenden Tropfen aufgenommen, Potentiale gegen Bodenquecksilber; $\mathrm{d} E / \mathrm{d} t=0,03 \mathrm{~V} / \mathrm{s}$

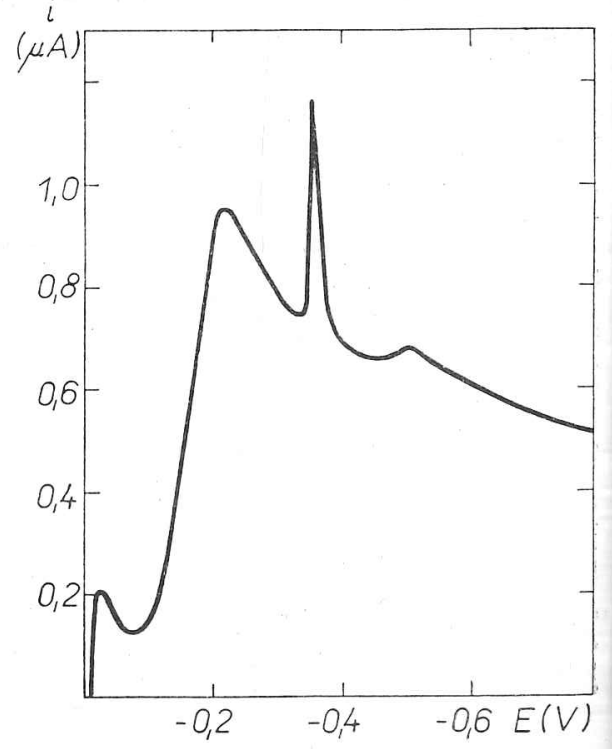

Ein genauer Vergleich dieses Wertes mit dem experimentell gemessenen setzt 作 die den Rahmen dieser qualitativen Mitteilung überschreitet. PRÍSPEVOK K ELEKTROLYTICKÝM REAKCIÁM IÓNOV Mñ²+
ZA PRÍTOMNOSTI KYSLIKA

$$
\text { M. Heyrovský }
$$

Polarografický ústar, Československá akadémia vied,

$$
\text { Creskosk }
$$

Oscilografickou polarografiou, ako aj inými polarografickými metódami sa sleobjasnili trorbou hydroxidu mangánatého na povrchu elektródy. Vzniknutý hydroxid podlieha redukcii na kov alebo oxydácii na hydroxid manganitý.

К ЭЛЕКТРОЛИТИЧЕСКИМ РЕАКЦИЯМ ИОНОВ МАРГАНЦА(II) В ПРИСУТСТВИЙ КИСЛОРОДА

$$
\text { М. Гейровски }
$$

Полярографии теский пнститут, Чехословацкая академия наук Прат

Методом осциллографйческой полярографиии и другими полярографичческими методами исследовались әлектролити ческие реакции двухвалентного марганца в растворах солержаших хисторот. Реакпии были об̆тяснены об̆разованием на поверхности электрода гидроюкиси мартанца(II), подвергающейся восстановлени ю до металла или окислению до гидроокиси марганца(III).

\section{LITERATUR}

1. Bieber R., Trümpler G., Helv. Chim. Acta 30, 971 (1947). nické literatury, Prahe 1953

emula W., Galus Z., Roczniki Chem. 36, 1223 (1962)

4. Kaufman D. C., Loveland J. W., Elving P. J., J. Phys. Chem. 63, 217 (1959).

5. Behr B., Chodkowski J., Roczniki Chem. 26, 650 (1952).

6. Heyrovský J., Anal. Chim. Acta 8, 283 (1953).

Kemula W., Kublik Z., Roczniki Chem. 30, 1259 (1956).

. Kemula W., Sprawozd. Tow. Nauk. Warz., Wydz. III. 40,3 (1947).

. Latimer W. M., Oxidation Potentials, 2nd ed., 237. Prentice-Hall, New York 1952.

Porographie mit Wechselstrom, 88

1. Laitinen H. A., Frank A. J., Kivalo P., J. Am. Chem. Soc. 75, 2865 (1953).

Fingegangen am 16 September 1963 
R. Kalvoda bemerkt, daß der Einfluß des Sauerstoffes auch bei einigen organischen Verbindungen wie zweiwertige Fenole beobachtet wurde. Bei der Reduktion des Sauerstoffes in neutraler Losung wird die Elektrodenober ache alkden dann bei dem folgenden Milieu werden die zwoiw wisty kathodischen Vorgang elekrolytisch reduziert. M. Schulz macht aufmerksm auf den M. Heyrovskey antwortet, daß er keinen bedeutendsten $\mathrm{Einfluß}$ von $\mathrm{H}_{2} \mathrm{O}_{2}$ auf die be schriebenen Erscheinungen beobachtet hat. 


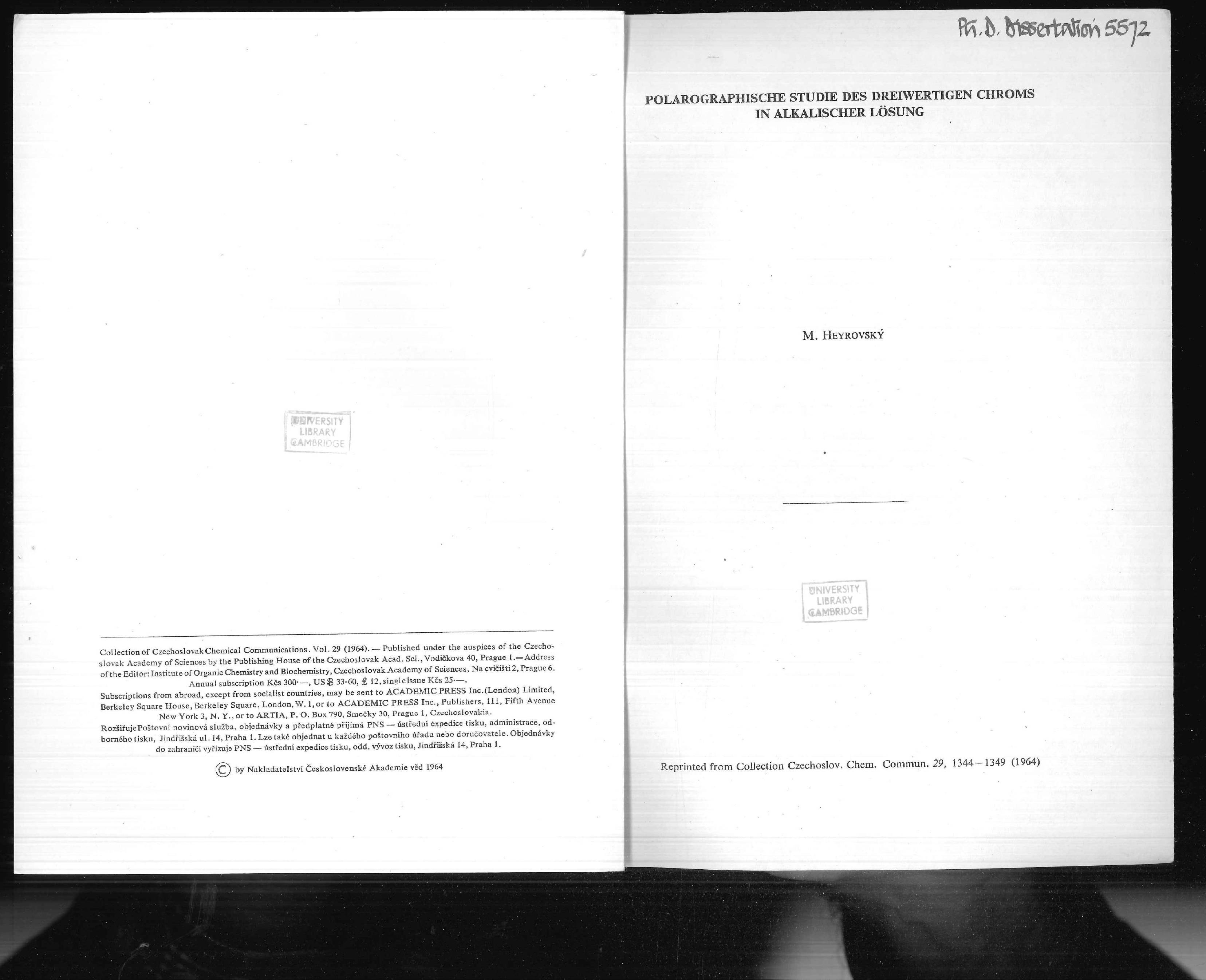


POLAROGRAPHISCHE STUDIE DES DREIWERTIGEN CHROMS IN ALKALISCHER LÖSUNG

M. HEYRovSKÝ

Polarographisches Institut, Tschechoslowakische Akademie der Wissenschaften, Prag Eingegangen am 17. Juni 1963

Die polarographische Stufe der Oxydation des Chromits zu Chroma wird beschrieben. Thr Grenzstrom ist durch die Diffusionsgeschwindigket Abfall der Stufe folst do Band sinkt mit der Zeil. Aus dem zeitlichen

Bei der Untersuchung alkalischer Lösungen von Chrom(III)-salzen mit Hilfe der Methoden der oszillographischen Polarographie ${ }^{1,2}$ wurde festgestellt, da $B$ an der Oberfläche der Trestestell, daß an der lösung lossung polarisiert wird, Chromat entsteht, das bei negativeren Potentialen der Reduktion unterliegt. Da die Oxydation des dreiwertigen Chroms an der Quecksilberelektrode bisher nicht beschrieben wurde, haben wir uns die Aufgabe gestellt, diese Reaktion mit Hiffe der Klassischen Polarographie zu erforschen. Die polarographische Untersuchung der alkalischen Lösungen des dreiwertigen Chroms versprach außerdem, neue Erkenntnisse über das chemische Verhalten der Chromite zu bringen, das bisher nicht ganz geklärt war.

\section{Experimenteller Teil}

Die polarographischen Kurven wurden mit dem Polarographen Yanagimoto PA-101 registriert. Die angewandte Kapillare vom Typus nach Smoler hatte bei $50 \mathrm{~cm}$ hoher Quecksiibersäule die Ausflußgeschwindigkeit $m=0,68 \mathrm{mg} / \mathrm{s}$ und die Tropfzeit von 4,37 $\mathrm{s}$ in $1 \mathrm{~N}$-KCl-Lösung beim

Die Chrom(III)-Lösungen wurden direkt im Elektrolysegefäß durch Pipettieren von 0,1 oder Die Uut entüifteten Hydroxid-Lösung dargestellt.

Die Untrode vorgenommen, Wasserbad befand. Der Luftsauerstoff wiurde durch Durchperlen mit Stickstof thermostatisierten vertrieben. Die angewandten Chemikalien vom Reinheitsgrad pro analysi waren duschungen Erzeugnisse der Firma Lachema.

Polarographische Studie des dreiwertigen Chroms in alkalischer Lösung

Ergebnisse und Diskussion

Polarographisches Verhalten der Chromite

Alkalische Lösungen von dreiwertigem Chrom geben eine polarographische Oxydationsstufe (Abb. 1), deren Halbstufenpotential um weniger als $100 \mathrm{mV}$ vor dem anodischen Strom der Quecksilberauflösung liegt. Um die Stufe messen zu können, wurden die Kurven im Maßstab von $10 \mathrm{mV} / \mathrm{cm}$ registriert. Im untersuchten Konzentrationsbereich von $1 \cdot 10^{-4}$ bis $5 \cdot 10^{-3} \mathrm{M}$ und bei mindestens 50 fachem Laugenüberschuß ist die Höhe der Stufe der Konzentration des Chroms direkt proportional und unabhängig von der der Hydroxidionen. Vermindert man das Konzentrationsverhältnis der $\mathrm{OH}^{-}$-Ionen zu den Chrom(III)-Ionen, so sinkt die Stufe und verschwindet schließlich beim Konzentrationsverhältnis 10:1 praktisch von der Kurve. Angefangen von $10^{-3}$ molarer und höherer Konzentration erscheint auf dem Grenzstrom der Stufe ein Abfall, dessen Natur nicht näher untersucht wurde.

Die Abhängigkeit von der Höhe der Quecksilbersäule zeigt an da $\beta$ der Grenzstrom nur durch die Differionseschwindigkeit des Depolaristors bestimmt ist. Die Höhe nur duch dist. Die Höhe in $0,1 \mathrm{M}-\mathrm{NaClO}_{4}-\mathrm{D}$

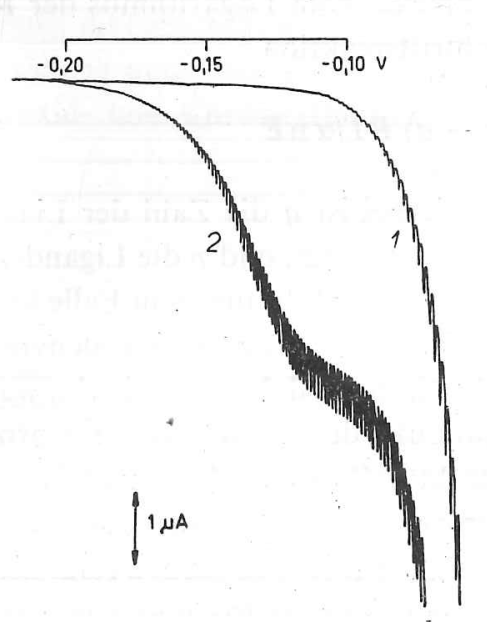

Abb.

Polarographische Stufe der anodischen Oxydation des Chromit

$0,1 \mathrm{M}-\mathrm{KOH}$, Konzentration des $\mathrm{KCr}\left(\mathrm{SO}_{4}\right)_{2}$ $10 ; 25 \cdot 10^{-4} \mathrm{M}$. Kurvenbeginn $-0,2 \mathrm{~V}$, sKE

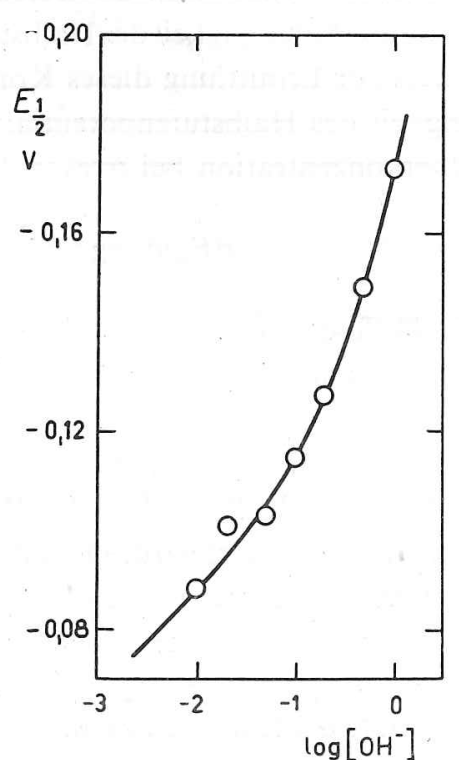

ab. 2

Abhängigkeit des Halbstufenpotentials des Chromits von der Hydroxidionenkonzentration bei konstanter Ionenstärke ösung von $5 \cdot 10^{-4} \mathrm{M}-\mathrm{KCr}\left(\mathrm{SO}_{4}\right)_{2}$ in $\mathrm{KOH}$, 
Heyrovsk:

spricht folglich einer Dreielektronen-Oxydation. Die logarithmische Analyse ergib eine Gerade; der Reziprokwert ihrer Neigung beträgt in $10^{-2}, 10^{-1}$ und $1 \mathrm{M}-\mathrm{KOH}$ $30 \mathrm{mV}$. Hieraus ergibt sich für den Koeffizienten $\alpha$ der Wert $2 / 3$ (bei $\mathrm{n}=3$ ). Aus der Differ der Chromits zu Chromat und der Reduktion des Chromats zu Chromit ${ }^{3}$, die etwa $0,7 \mathrm{~V}$ beträgt, ist der stark irreversible Charakter der Durchtrittsreaktion erkennbar. In Anwesenheit eines indifferenten Elektrolyten $\left(\mathrm{KNO}_{3}, \mathrm{NaClO}_{4}\right)$ verschiebt sich die Stufe nach positiven Potentialen. Die Abhangigkeit des Halbstufenpotentials von der Hydroxidionenkonzentration bei konstanter Ionenstärke ist in Abb. 2 dargestellt.

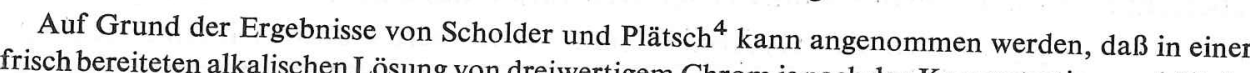
sen mehrere Chrom(III)-Komplexe existieren, die sich untereinander im Gleichsewicht befinden-

$\left[\left(\mathrm{H}_{2} \mathrm{O}\right)_{2} \mathrm{Cr}(\mathrm{OH})_{4}\right]^{-}, \quad\left[\left(\mathrm{H}_{2} \mathrm{O}\right) \mathrm{Cr}(\mathrm{OH})_{5}\right]^{2-}, \quad\left[\mathrm{Cr}(\mathrm{OH})_{6}\right]^{3-}, \quad\left[\left(\mathrm{H}_{2} \mathrm{O}\right) \mathrm{Cr}(\mathrm{OH})_{7}\right]^{4-}$,

$$
\left[\mathrm{Cr}(\mathrm{OH})_{8}\right]^{5-}
$$

(die Natriumsalze der letzten drei Komplexe wurden im kristallinen Zustand dargestellt).

Ist das Gleichgewicht zwischen den Komplexen mobil und überwiegt bei der betrachteten Hydroxidionenkonzentration stets ein bestimmter Komplex gegenïber detachren, so kann die Abhängigkeit des Halbstufenpotentials von der Konzentration des plexbildners zur Ermittlung dieses Komplexes benutzt werden. Aus der Neig KomAbhängigkeit des Halbstufenpotentials des Komplexes vom Log dor Neigung der plexbildnerkonzentration bei irreversibler Durchtrittsreaktion

$$
\mathrm{d} E_{\frac{1}{2}} / \mathrm{d} \log \left[\mathrm{X}^{-}\right]=-(p-q) \boldsymbol{R} T / \alpha \mathrm{n} \boldsymbol{F}
$$

kann die Differenz $(p-q)$ ermittelt werden. Hierbei ist $q$ die Zahl der Liganden des Komplexes, der direkt der Durchtrittsreaktion unterliegt, und $p$ die Ligandenzahl des Komplexes, der in der betrachteten Lösung überwiegt ${ }^{5}$. In unserem Falle können wir versuchen, an Hand eines Vergleichs der Struktur der für den Elektrodenvorgang in Frage kommenden Komplexe den Wert $q$ zu bestimmen, d. h. zu ermitteln, welcher Komplex direkt oxydiert wird. Dem Reaktionsprodukt, dem tetraedrischen ChromatAnion, steht das Tetrahydroxochromit-Ion strukturell am nächsten; es ist wahrsönne dar konner desh tion ${ }^{2}$. $10^{-4} \mathrm{Losung}$ von Chrom(III)-Ionen bei einer Hydroxidionenkonzentration de überwiegende Komplexform ist $\left(\mathrm{d}_{\frac{1}{2}} / \mathrm{d} \log [\mathrm{OH}]^{-}=30 \mathrm{mV}\right)$. Bei zehnmal höherer Laugenkonzentration ist cs das Hexahydroxochromit-Anion $\left(-\mathrm{d} E_{\frac{1}{2}} / \mathrm{d} \log \left[\mathrm{OH}^{-}\right]=60 \mathrm{mV}\right)$ und in Kaliumhydroxid von etwa 1M Konzentration überwiegt das Heptahydroxochromit über den übrigen Komplexen $\left(-\mathrm{d} E_{\frac{3}{2}} / \mathrm{d} \log \left[\mathrm{OH}^{-}\right]=90 \mathrm{mV}\right)$. Zum gleichen Ergebnis in bezug auf das Mengenverhältnis der einzelnen Chrom(III)-komplexe in
Polarographische Studie des dreiwertigen Chroms in alkalischer Lösung

Lösung führt auch die Methode von Koryta ${ }^{6}$, bei der der Strom bei konstantem Potential in Abhängigkeit von der Konzentration des Komplexbildners gemessen wird. Sind also die oben angeführten Voraussetzungen über die Eigenschaften des Systems der Chrom(III)-komplexe richtig, so können wir für die elektrolytische Oxydation des dreiwertigen Chroms in alkalischem Milieu folgende Bruttoreaktion ansetzen:

$$
\left[\left(\mathrm{H}_{2} \mathrm{O}\right)_{2} \mathrm{Cr}(\mathrm{OH})_{4}\right]^{-}+4 \mathrm{OH}^{-} \rightarrow \mathrm{CrO}_{4}^{2-}+3 \mathrm{e}+6 \mathrm{H}_{2} \mathrm{O}
$$

Verfolgung der Reaktion in der Lösung

Bei der Untersuchung des polarographischen Verhaltens der Chromite wurde beobachtet, daß ihre anodische Stufe mit der Zeit sinkt. Dieser Effekt ist augenbeobachtet, daß ho a scheinlich die Folge des bekne Beispiel auch der Abfall der Anfangsgeschus stoffperoxid zurückzufuhren ist. Der Abfall der polarographischen Stufe ist in gesamten untersuchten Konzentrationsbercich im Hinblick auf das Chrom durch die Beziehung für Reaktionen zweiter Ordn digkeitskonstanten dieser Reaktion wurden durch die graphische Methode ermittelt. Sie haben nur formale Bedeutung, da si sich immer nur auf eine bestimmte Verteilung der Komplexe beziehen, deren absolute Konzentration nicht bekannt is und sich je nach der Konzentration der Hydroxid- und Chrom(III)-Ionen ändert.

\section{Abb. 3}

Zeitlicher Abfall des Chromit-Grenzstromes $9 \cdot 10^{-4}{ }_{\mathrm{M}-\mathrm{KCr}} \mathrm{K}\left(\mathrm{SO}_{4}\right)_{2}$ in $9 \cdot 10^{-2} \mathrm{M}-\mathrm{KOH}$ Zeitliche Anderung der Stufenhöhe, $\left[\left(i_{\mathrm{d}}\right)_{0}-i_{\mathrm{d}}\right] i_{\mathrm{d}}$ von der Zeit; der lineare Verlauf $\left[\left(I_{\mathrm{d}}\right)_{0}-i_{\mathrm{d}}\right] / i_{\mathrm{d}}$ von der Zeit; der lineare Verlau
entspricht einer Reaktion zweiter Ordnung.

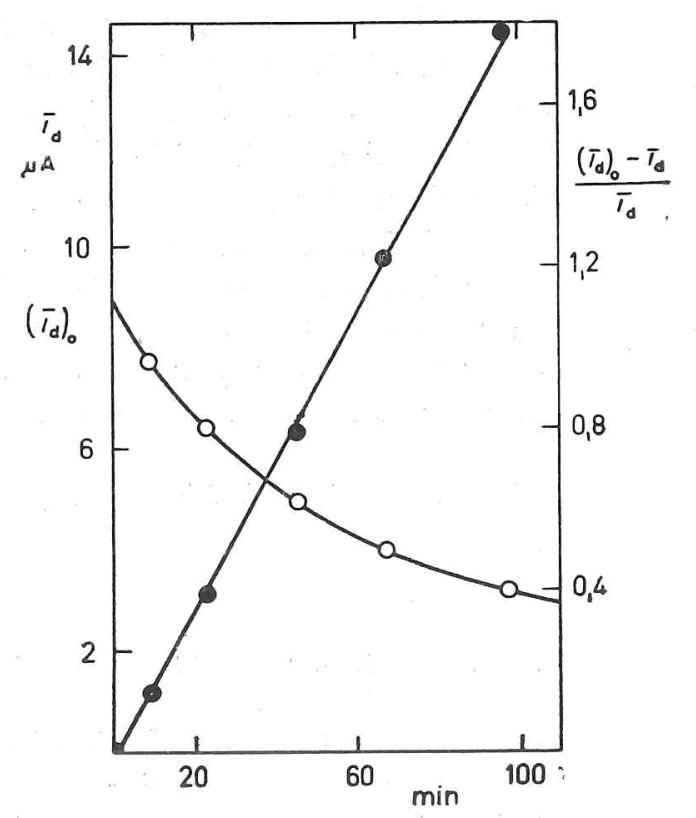

Mit wachsender Hydroxidionenkonzentration sinkt der Wert der Rcaktionsgeschwindigkeitskonstante (Tab. I). Dies läßt sich dadurch erklären, daß die Komplexe mit niedrigerer Zahl an Hydroxid-Liganden leichter der chemischen Reaktion unterliegen.

vol. 29. [1964) 
Heyrovsky:

Tabelle I

Abhängigkeit der Dimerisationsgeschwindigkeitskonstante des Chromits von der Hydroxidionen-

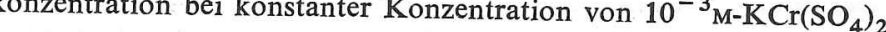

\begin{tabular}{|c|c|c|c|c|}
\hline $\begin{array}{c}{\left[\mathrm{OH}^{-}\right]} \\
\mathrm{mol} 1^{-1}\end{array}$ & $5 \cdot 10^{-2}$ & $1 \cdot 10^{-1}$ & $1,5 \cdot 10^{-1}$ & 1 \\
\hline $\begin{array}{c}k \cdot 10^{2} \\
1 \mathrm{~mol}^{-1} \mathrm{~s}^{-1}\end{array}$ & 38 & 21 & 11 & 6,5 \\
\hline
\end{tabular}

Die Chrom(III)-komplexe sind befăhigt, sich vermittells von Diolbrücken miteinander zu ver-

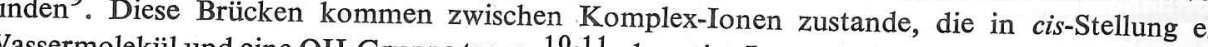
und Pentahydroxochromit. Gevperas

Im Hinblick auf die elektrische Ladung des Komplexes kann erwartet werden, da $B$ sich die Dimerisation am schnellsten zwischen zwei Tetrahydroxochromit-Teilchen vollziehen wird; der Pentahydroxokomplex wird wahrscheinlich bei höherer Laugenkonzentration in der Reaktion zur Geltung kommen. Komplexe mit höherer Z an $\mathrm{OH}$-Liganden kommen für die Reaktion bereits nicht mehr in Betracht; die erklärt die relative Beständigkeit der Chromite in konzentrierten Laugenlösur, ${ }^{12}$ Das zweikernige Chromit ist in dem an der Quecksilberelektroce zugun Potentialbereich bereits nicht mehr oxydierbar. Infolgedessen ist es nich mich seine weitere Reaktion in der Lösung polarographisch zu verfolgen. Es ist wahrscheinlich, daß es, ähnlich wie bei der Hydrolyse de Chron(II) Es ist seh stufenweisen Bildung großer mehrerni Ker Komplexe Das Anfangsstadium des Alterns von wäBrigen Chrom(III)-Lö Charakters komm nach nicht auf der Abseruht demnach nicht auf der Abscheidung von Chrom(III)-hydroxid, sondern auf der Bildung lbrücken

Frau V. Kailovả spreche ich für die Anfertigung der Abbildungen meinen Dank aus.

Literatur

. Heyrovský J. im Buche: Advances in Polarography (. S. Longmuir Ed.), Bd. 1, S. 18. Pergamon Press, London 1960.
2. Heyrovský M.: Chem. zvesti 14, 834 (1960).

3. Lingane J. J., Kolthoff I. M.: J. Am. Chem. Soc. 62, 852 (1940).

4. Scholder R., Pätsch R.: Z. anorg. u. allgem. Chem. 220, 411 (1934).

5. Matsuda H., Ayabe Y.: Bull. Chem. Soc. Japan 29, 134 (1956).

7. Fricke $\mathrm{R}$.: Windhausen $\mathrm{O}: \mathrm{Z}, 3057$ (1959)

8. Baloga M. R. Farley J. F. J. Am. Chem. So,. Chem. 132, 273 (1924).

9. Pfeiffer P. Stern R. Z anorg. Chem. $58,240,280(1908)$.

10. Hein F.: Chemische Koordinationslehre, S. 176. Hirzel, Leipzig 1954.
Polarographische Studie des dreiwertigen Chroms in alkalischer Lösung

11. Grant D. M., Hamm R. E.: J. Am. Chem. Soc. 78, 3006 (1956).

. (3) 1950

М. Гейровский: Полярограбическое изучение трехвалентного хрома в щелочном растворе управляется скоростьюс диффуузин окисления хромита до хромата. Предельный ток последнеи волны во времени вытекает, что хромит подвергается в растворе реакции второго поряли с образованием двухядерного комплекса. 


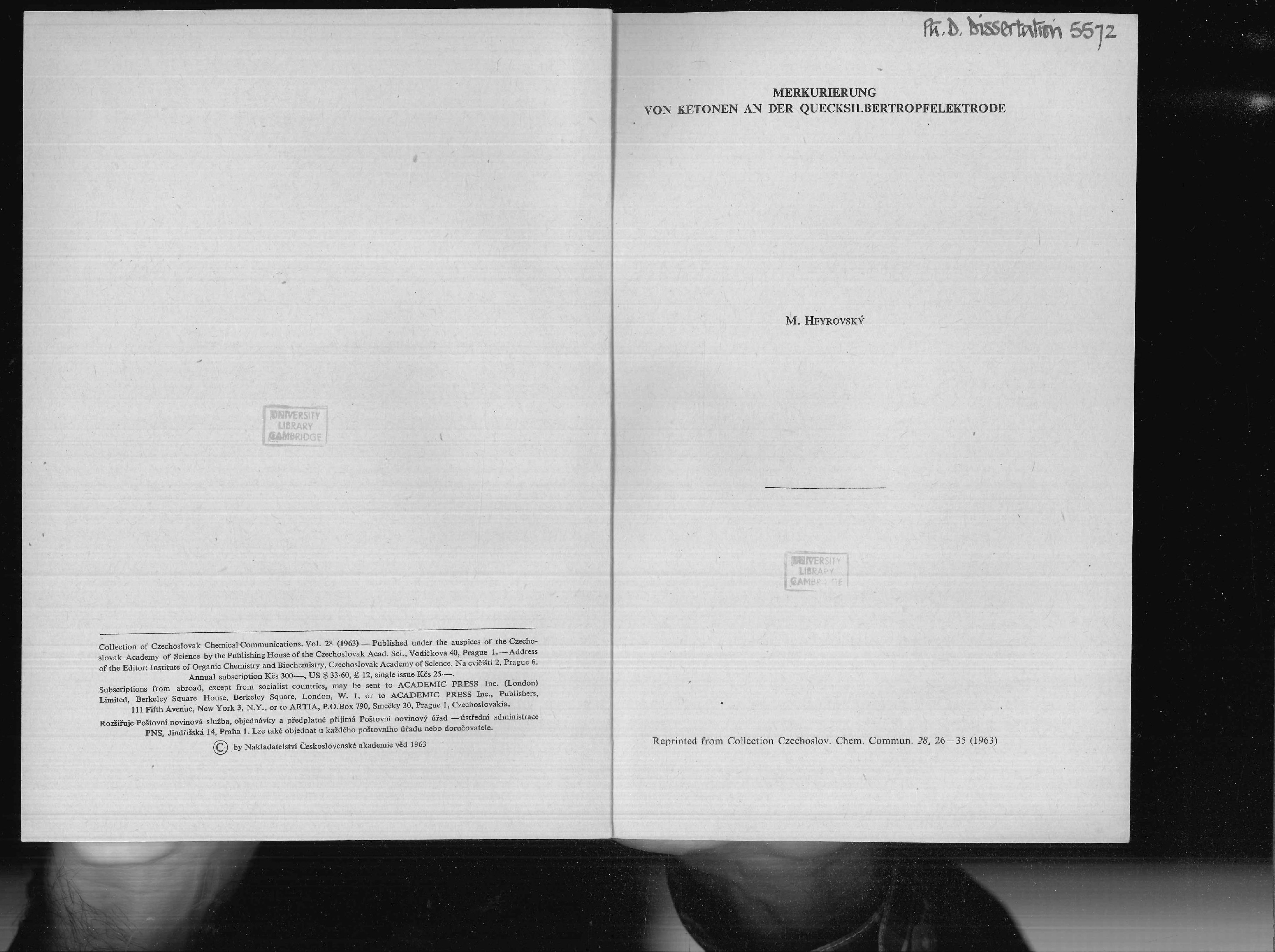


MERKURIERUNG

VON KETONEN AN DER QUECKSILBERTROPFELEKTRODE

\section{HeYRovsKÝ}

Polarographisches Institut, Tschechoslowakische Akademie der Wissenschaften, Prag Eingegangen am 11. Januar 1962

Ketone bilden in alkalischem Milieu eine anodische polarographische Stufe, die diden in all iner Oranoquecksilberverbindung entspricht Der zugehörige Strom ist durch die Geschwindigkeit der autokatalysierten chemischen Reaktion bestimmt, die der Durchtrittsreaktion vorgelagert ist. Auf Grund der Vorstellung, daß die Bildung der Enolform des Ketons der geschwindigkeitsbestimmende Schritt der Merkurierung ist, wurde die Enolisierungsgeschwindigkeit des Acetons aus den polarographischen Messungen berechnet. Sie stime grobenordnungsgenaß mit den Literatingaben wurden.

In Ketonen, die Wasserstoffatome in $\alpha$-Stellung enthalten, lassen sich diese leich durch Quecksilber ersetzen ${ }^{1,2}$. Die Ergebnisse der oszillopolarographischen Beobachtungen $^{3}$ haben gezeigt, daß diese Reaktion in alkalischem Milieu an der Quecksilbertropfelektrode abläuft. Aus Vorversuchen ging hervor, daß das polarographische Studium dieser Reaktion neue Erkenntnisse über den Mechanismus der Merkurierung bringen wird.

\section{Experimenteller Teil}

Die polarographischen Kurven wurden mit den Polarographen der Typen Zbrojovka V 301 Radiometer PO 4 und Yanagimoto PA-101 registriert. Als Umschalter diente die von Kalousel und Rálek ${ }^{4}$ beschriebene Einrichtung. Die $i-t-$ Kurven wurden mit dem von Němec und Smoler

digkeit $m=2,15$. 10 Kalomelelektrode $t_{1}=3,68 \mathrm{~s}$. Als stationäre Elektrode diente die von Vogel $^{6}$ beschriebene Elektrodentype, als vibrierende Platinelektrode die Elektrode nach Jenšovský geführt. Die Lösungen haben wir durch einen Stickstoffs'strom vom Sauerstoff befreit. Der daz benutzte Stickstoff wurde dabci vort dich 年 us Kaliumpermangant destilliert Die anorganischen Präparate waren von analytischer Reinheit. Das merkurierte Aceton war nach Morton und Penner ${ }^{8}$ dargestellt worden und in Form des
Merkurierung von Ketonen an der Quecksilbertropfelektrode

Nitrates oder Jodids isoliert. Das Nitrat ist in Aceton sehr gut löslich, den polarographischen Ergebnissen gemäß lösen sich in Wasser bei der Temperatur von $20^{\circ} \mathrm{C}$ etwa $1,5 \mathrm{~g}$ Substanz in

Ergebnisse

Aceton liefert eine anodische polarographische Stufe mit Halbstufenpotential $-0,23 \mathrm{~V}$ (ges. KE) (Abb. 1). Diese Stufe erscheint nur in alkalischen Lösungen und wächst mit steigender Hydroxydkonzentration (Abb. 2). Bei konstanter Kaliumhydroxydkonzentration(

in den Grenzen von $10^{-3}$. bis $10^{-2} \mathrm{M}$ Aceton der Beziehung $i_{1}=\left[\mathrm{CH}_{3} \mathrm{COCH}_{3}\right]^{2} / 60 \mathrm{~A}$.

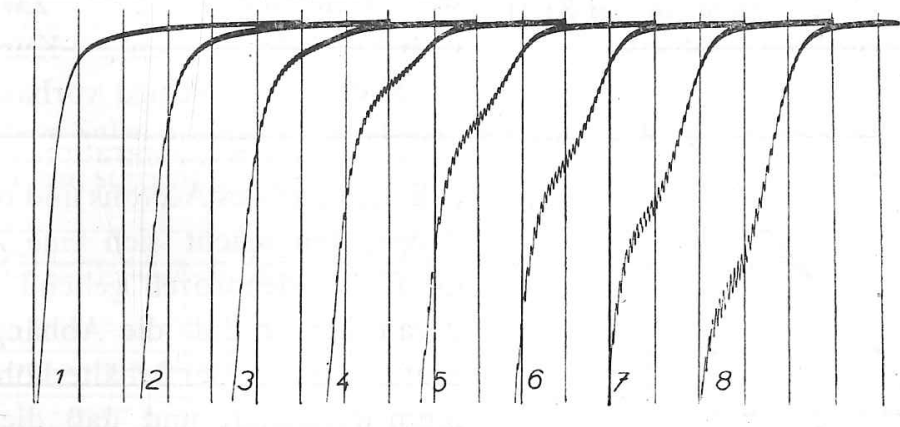

Abb. 1

1M-KOH; Acetonkonzentration: $10 ; 22 \cdot 10^{-3} \mathrm{M} ; 34 \cdot 10^{-3} \mathrm{M} ; 46 \cdot 10^{-3} \mathrm{M} ; 58 \cdot 10^{-3} \mathrm{M} ; 610$ $10^{-3} \mathrm{M} ; 712 \cdot 10^{-3} \mathrm{M} ; 814 \cdot 10^{-3} \mathrm{M}$. Kurvenbeginn bei $-0,4 \mathrm{~V} ; 50 \mathrm{mV} /$ Absz.; Empf. $1: 20$

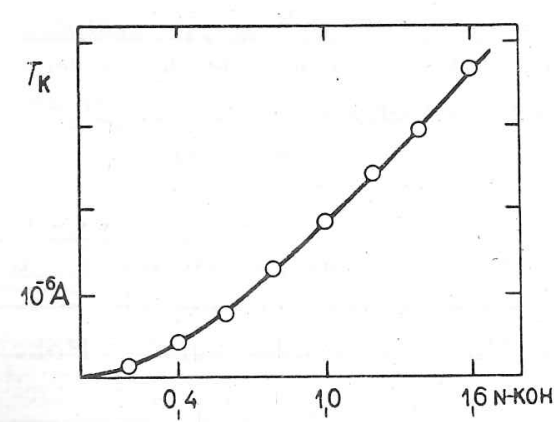

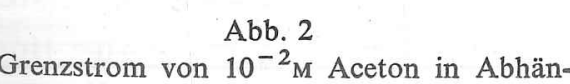
gigkeit von der Kaliumhydroxydkonzentration

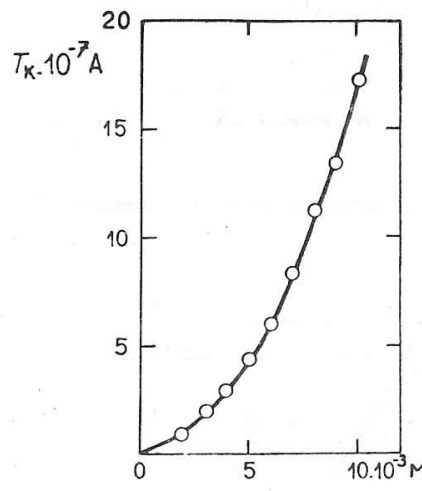

Abb

Grenzstrom in Abhängigkeit von der Acetonkonzentration in $1 \mathrm{M}-\mathrm{KOH}$ 
Heyrovský:

Meßbare Stufen gewinnt man, wenn die Konzentration des Hydroxyds größer als $0,1 \mathrm{M}$ und die des Acetons größer als $10^{-3} \mathrm{M}$ ist.

Der Anstieg der Stufenhöhe mit sinken-

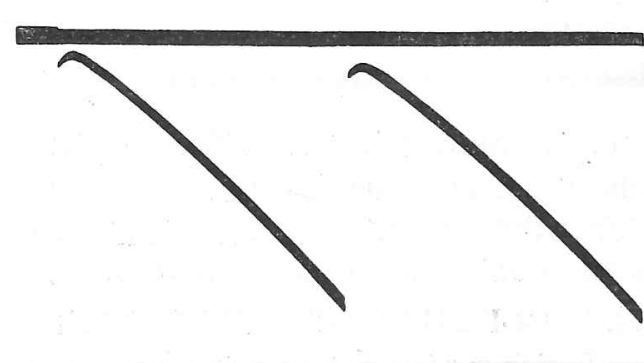
Dueckilbersule zeugt von autokatasyliertem Charakter des Stromes. Im Einklang damit ist auch die Gestalt der bei dem Potential des Grenzstromes registrierten $i-t-$ Kurven, die die Zeitabhängigkeit des momentanen Stromes ausdrücken (Abb 4). Die Abhängigkeit des Logarithmus des Abb. 4 momentanen Stromes vom Logarithmus Erste und zweite $i-t$-Kurve bei der Konzenam Grenzstrom registriert

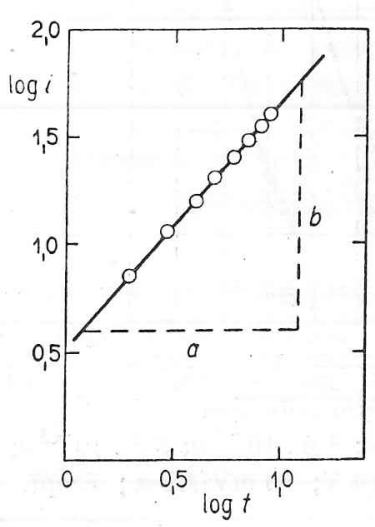

Abb. 5
Logarithmische Analyse der $i-t$-Kurven Analyse
aus Abb. 4
$b: a=1,15$

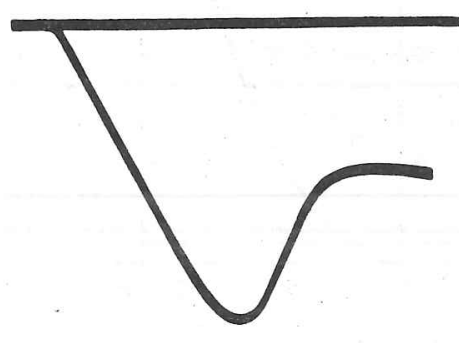

abb. 6 $i-t-$ Kurven bei der Konzentration von
$8,10^{-2} \mathrm{M}$ Aceton in $1 \mathrm{M}-\mathrm{KOH}$ am Grenzstrcm registrert

der Zeit ist linear (Abb. 5) und entsprich der Beziehung $i \sim t^{1,15}$. Zwischen der ersten und der zweiten $i-t$-Kurve ist kein merklicher Unterschied vorhanden.

Bei höheren Konzentrationen der Hydroxylionen und des Acetons und bei längeren Tropfzeiten macht sich eine Adsorption im Elektrodenprozeß geltend. Das geht daraus hervor, daß die Abhangigkeit der Stufenhöhe von der Behâlterhơhe ein Maximum durchläuft und daß die Stufe bei hohen Konzentrationen mit abnehmender Quecksilbersäule sinkt. Auch die Gestalt der $i$ - $t$-Kurven erweist, daß der ursprüngliche autokatalytische Prozeß durch Adsorption gehemmt ist (Abb. 6).

Die Höhe der anodischen Stufe des Acetons wächst beträchtlich mit der Temperatur; bei $25^{\circ} \mathrm{C}$ haben wir für den Grenzstrom den Temperaturkoeffizienten $\left(\mathrm{d} \bar{i}_{1} / \mathrm{d} T\right.$. $\left.1 / i_{1}\right)_{25^{\circ}}=6,8 \mathrm{grad}^{-1}$ gefunden.

Gelatine erniedrigt die Acetonstufe derGelating $4.10^{-2} \mathrm{~m}$ Aceton scho $10^{-2} \%$ elation auf auf die Halte ins 7). Durch den Gezu unterdrücken (Abb. ). Durch den Gelatinezusatz verliert der Strom seinen autokatalytischen Charakter, wie aus der Höhenabhängigkeit und aus den $i-t$-Kurven hervorgeht.
Merkurierung von Ketonen an der Quecksilbertropfelektrode

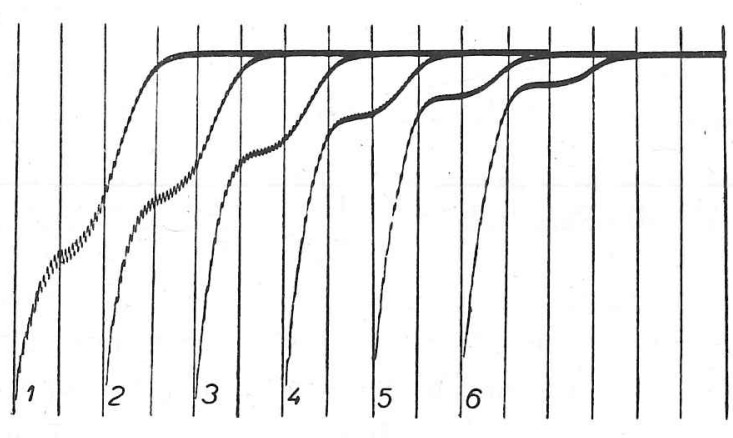

Abb. 7

Einfluß von Gelatine auf die anodische Stufe des Aceton

Losung von $4 \cdot 10^{-2} \mathrm{M}$ Aceton in $1 \mathrm{M}-\mathrm{KOH} ;$ Gelatinekonzentration: $10 ; 20,5 \cdot 10^{-2} \% ; 31,0$ beginn bei $-0,4 \mathrm{~V}$.

Verschiedene Salze üben eine spezifische Wirkung auf den Grenzstrom des Acetons aus (Abb. 8); am stärksten wird die Stufe durch Kaliumbromid herabgesetzt, wenige durch Kaliumchlorid und -itrat; Phospht und Sulf terio Durch die Gesenwart von Äth

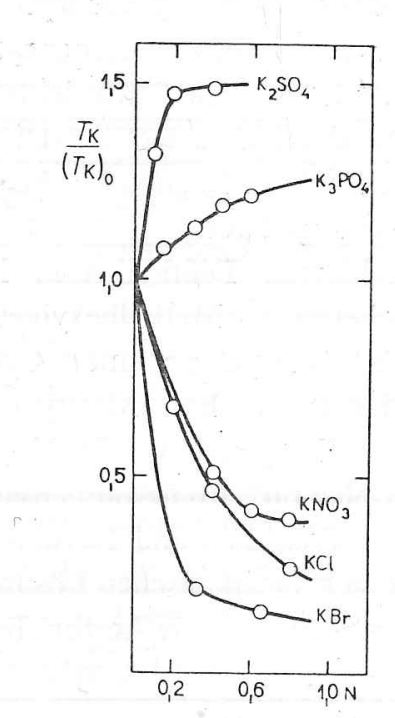

Abb. 8 vermindert.

Die mit dem Kalousek-Umschalter gewonnenen Ergebnisse zeigen, daß das bein

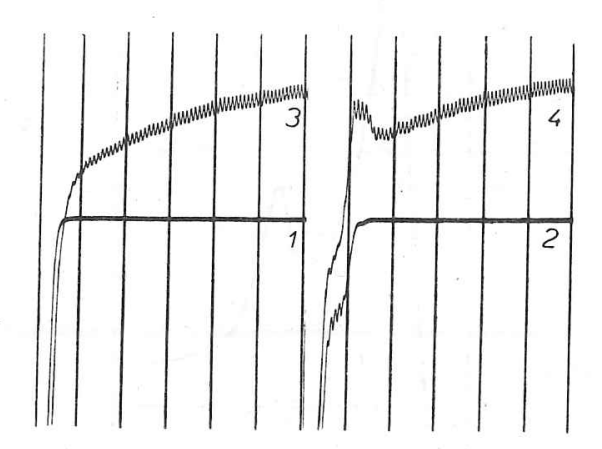

Abb. 9

Anodische Stufe des Acetons mit dem Ka-

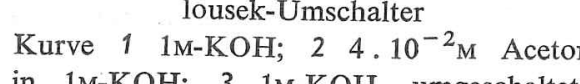
Kurve, $E_{1}, 3-\mathrm{M}-\mathrm{KOH}$, umgeschaltete

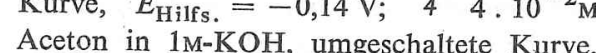
Einfluß von Anionen auf den Grenzstro des Acetons, ausgedrückt durch das Ver-
hältnis der Stufenhöhe in 1M-KOH-Lösun mit dem betreffienden Salz zur Stufenhöhe in reinem $1 \mathrm{M}-\mathrm{KOH}$

$E_{\text {Hilfs. }}=-0,14 \mathrm{~V} ; \quad f=25 \mathrm{~Hz} ; 200 \mathrm{mV}$ Absz., Empf.: $1: 100$. 
Heyrousky:

Potential der anodischen Stufe entstandene Produkt reversibel an der Elektrode reduziert wird. Bei höheren Umschaltfrequenzen (etwa von $20 \mathrm{~Hz}$ an) bildet sich reduziert wird. Bei thodischen Teiles der umgeschalteten Stufe ein kleines Maximum (Abb. 9).

Auch die Versuche mit der stationären Tropfenelektrode führen zu den gleichen Schlüssen über die Reversibilität der anodischen Reaktion. Der anodische Strom, der der Bildung des Oxydationsproduktes entspricht, geht kontinuierlich in eine der Reduktion dieses Produktes angehörende kathodische Strompitze mit dem Maximu bei $-0,30 \mathrm{~V}$ (ges. KE) über, die von einer kleinen Stromspitze beim Potential $-0,47$ Beläßt man die stationäre Elektrode 1 - 2 min auf dem Potentia der Bildung des Oxydationsproduktes und bringt sie dann nach 1-5 minutiger Unter Potentiale, so verschiebt sich das Unter eälnis der ersten und zweiten Stromspitze zugunsten de gegenseltige Howar 2Weiten, selben Potenling oder in Gegenwart organischer Losd Kurve aus. Aus diesen Verhalten und der anodischen Reaktion an der Elektrode adsorbiert wird, kann geschlossen werden,

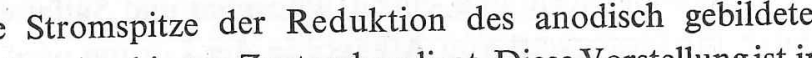
Depolarisators angehört, der im adsorierten Zustand vorliegt. Diese Vorstellung ist im

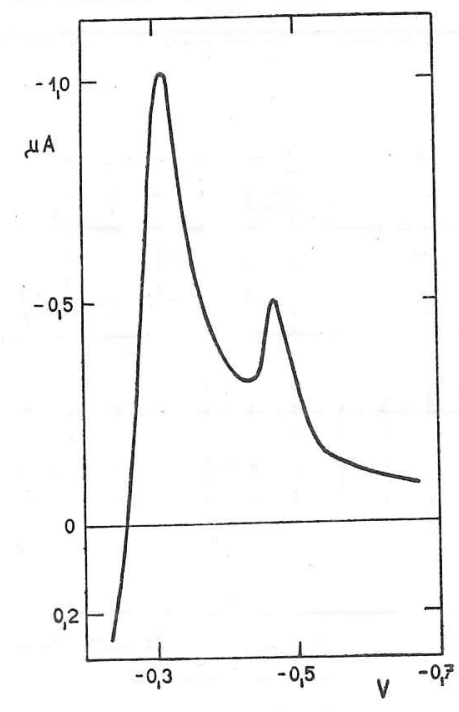

Abb. 10 Einklang mit der Deutung der Adsorptionsstufen in der klassischen Polarographie. Die mit der vibrierenden Platinelektrode in Laugelösungen erhaltenen Polarisationskurven wiesen nach der Zugabe von Aceton keine Veränderungen auf.

Methyläthylketon, Diäthylketon, Methylisopropylketon, Methylhexylketon, Methylnonylketon, Cyclopentanon, Cyclohexan on, Diacetonalkohol, Mesityloxyd, Acetophenon, Phenylaceton, Propiophenon, Butyrophenon, Brenztraubensäure, Phenylbrenztraubensäure und Lävulinsäure verhalten sich in alkalischen Lösungen polarographisch analog wie Aceton Benzpolarographisch analog we Aceton. Benzaldehyd, Benzophenon, Phenylglyoxalsaure, Malonsaurc, Alhylacetal, Acetonitril und Phenylisopropylketon heferten Polarographische Kurve des Acetons mit Keine anodische Stufe in alkallscher Ködem hängenden Quecksilbertropfen sung. Harnstoff, Acetamid und Urethan $1 \mathrm{M}-\mathrm{NaOH}, 0,1 \mathrm{M}$ Aceton; Geschwindigkeit bilden eine anodische Stufe mit abweichender Polarisationsveränderung $-400 \mathrm{mV} / \mathrm{min}$. den Eigenschaften.

\section{Merkurierung von Ketonen an der Quecksilbertropfelektrode}

Diskussion

Die beschriebenen Versuche haben zur Vermutung geführt, daß das Quecksilber bei dem Potential der anodischen Stufe in Lösung geht und eine Organoquecksilberverbindung mit dem Keton bildet. Diese Vermutung wird auch durch den Versuch unterstützt, in welchem wir chemisch dargestelltes merkuriertes Aceton von de Zusammensetzung $\mathrm{CH}_{3} \mathrm{COCH}_{2} \mathrm{HgNO}_{3}$ der alkalischen Acetonlösung zugesetz haben. Auf der polarographischen Kurve (Abb. 11) erschien eine einzige anodischkathodische Stufe; ihr anodischer Teil entspricht der autokatalysierten Bildung des merkurierten Acetons und ihr kathodischer Teil dem Strom, der durch die Diffusion dieses Stoffes aus der Lösung ur Elektrode gegeben ist.

Abb. 11

Einfluß des merkurierten Acetons auf die Stufe der Merkurierung Einfluß des merkurierten Acetons auf
des Acetons

Kurve $15 \mathrm{ml} 10^{-2} \mathrm{M}$ Aceton in $1 \mathrm{M}-\mathrm{KOH}$; Kurve 2 nach Zusat von $0,1 \mathrm{ml}$ gesättigter Acetonylmerkurinitrat-Lösung. Kurvenbeginn gesattigter Acetonylmerkurinitrat-Lösung. K K
bei $-0,4$ V. $50 \mathrm{mV} / \mathrm{Absz}$., Empf. $1: 30$.

Über den Mechanismus der Merkurierung wird angenommen, daß das Quecksilber, ähnlich wie das Brom bei der Bromierung, mit der Enolform des Ketons reagiert, Vollzieht sich die eigentliche Reaktion des Enols mit dem Quecksilber genügend schnell, so ist die Gesamtgeschwindigkeit der Merkuieng duch die Enolisengegeschwindigkeit bestimmt. In unserem Fall, in welchem es sich und nach um die Reaktion des Enolat-Anions mit dem Quech Milieu handelt, können wir die Ceschwindigkeit Qu susen Disation in alkalischen als den Prozen beton tischer autokatalytische Charakter des Stromes ist wahrscheinlich darauf zurückzuführen, daß die Dissoziationsgeschwindigkeit des Ketons durch die katalytische Wirkung des eigentlichen Reaktionsproduktes, des merkurierten Acetons, erhöht wird. Dieses Katalysationsvermogen tritt deutlich zutage, wenn man der alkalischen Acetonlösung chemisch dargestelltes merkuriertes Aceton zugibt (Abb. 11): bei $10^{-4}$ molare Konzentration des zugesetzten Produktes wächst die anodische Stufe von $10^{-2} \mathrm{M}$ Aceton in 1M-KOH etwa um $100 \%$ an; eine weitere Konzentrationserhöhung hat keine Veränderung der Stufenh.öhe mehr zur Folge.

Wir nehmen an, daß die Merkurierung an der Quecksilbertropfelektrode über die nachstehende Reaktionsfolge abläuft:

$\begin{aligned} \mathrm{CH}_{3} \mathrm{COCH}_{3}+\mathrm{OH}^{-} & \rightleftarrows \mathrm{CH}_{3} \mathrm{COCH}_{2}-+\mathrm{H}_{2} \mathrm{O} \\ \mathrm{Hg}-2 \mathrm{e} & \rightleftarrows \mathrm{Hg}^{2+} \\ \mathrm{CH}_{3} \mathrm{COCH}_{2}-+\mathrm{Hg}^{2+} & \rightleftarrows \mathrm{CH}_{3} \mathrm{COCH}_{2} \mathrm{Hg}^{+} \\ \mathrm{CH}_{3} \mathrm{COCH}_{2} \mathrm{Hg}^{+}+\mathrm{OH}^{-} & \rightleftarrows \mathrm{CH}_{3} \mathrm{COCH}_{2} \mathrm{HgOH}\end{aligned}$

Vol. $28(1963)$ 


\section{Heyroosky:}

Der Strom ist durch die Reaktion (1) bestimmt, die der Durchtrittsreaktion (2) vorgelagert ist; die Reaktion (3) halten wir für sehr schnell.

Bei konstanter Hydroxylionenkonzentration, die hundert- bis tausendmal höhe ist als die Acetonkonzentration, folgt die Dissoziation praktisch der Gleichung für Reaktionen erster Ordnung, und wir können anstelle der Gleichung ( $I$ ) formal schreiben:

$$
\mathrm{CH}_{3} \mathrm{COCH}_{3} \underset{k-1}{\stackrel{k_{1}}{\rightleftarrows}} \mathrm{CH}_{3} \mathrm{COCH}_{2}{ }^{-} \text {. }
$$

Für die Dissoziationsgeschwindigkeitskonstante $k_{1}$ gilt hier

$$
k_{1}=k_{1}^{\prime}\left[\mathrm{OH}^{-}\right]+k_{1}^{\prime \prime}\left[\mathrm{OH}^{-}\right][\mathrm{M}]_{0},
$$

worin $[\mathrm{M}]_{0}$ die Konzentration des Reaktionsproduktes an der Elektrodenoberfläche ist, d. h. des merkurierten Acetons. Das zweite Glied auf der rechten Seite von Gleichung (6) drückt also den autokatalytischen Charakter der Merkurierung des Acetons an der Quecksilbertropfelektrode aus. Das Konzentrationsverhältnis der dissoziierten und der nicht dissoziierten Form bezeichnen wir mit $K$ :

$$
K=k_{1} / k_{-1}=\left[\mathrm{CH}_{3} \mathrm{COCH}_{2}^{-}\right] /\left[\mathrm{CH}_{3} \mathrm{COCH}_{3}\right] \text {. }
$$

In dieser Formulierung stellt die Merkurierung des Acetons vom polarographischen Gesichtspunkt einen völlig analogen Fall wie die Reduktion des Formaldehyds in Gesichtsputents ungepufter $\mathrm{Da} ß$ dieser Vergleich berechtigt ist, geht daraus hervor, daß bei niedrigeren Acetonkonzentrationen und kürzeren Tropfzeiten (wenn keine Adsorption zur Geltung kommt) der Grenzstrom des Acetons mit dem Quadrat der Konzentration wächst, wie es beim Formaldehyd der Fall ist . Der Q aldehyd ${ }^{10}$ proportional $t^{7 / 6}$, d. h. $t^{1,17}$; beim Aceton wurde experimentell der Exponent 1,15 gefunden

Nach der Näherungslösung 9 gilt für die mittleren polarographischen Grenzströme der Merkurierung des Acetons, $\bar{i}_{\mathrm{k}}$, die Beziehung:

$\left[\bar{i}_{\mathrm{k}} /\left(\bar{i}_{\mathrm{d}}-\bar{i}_{\mathrm{k}}\right)\right]^{2}=0,661 \mathrm{~K} \cdot t \cdot\left[\mathrm{OH}^{-}\right]\left(k_{1}^{\prime}+k_{1}^{\prime \prime}\left[\mathrm{CH}_{3} \mathrm{COCH}_{3}\right] \cdot \bar{i}_{\mathrm{k}} / \bar{l}_{\mathrm{d}} \cdot \sqrt{D_{\mathrm{A}} / D_{\mathrm{M}}}\right) \cdot(8)$

$\bar{\imath}_{\mathrm{d}}$ ist der hypothetische Diffusionsgrenzstrom des Acetons, $t_{1}$ die Tropfzeit, $D_{\mathrm{A}}$ der Diffusionskoeffizient des Acetons und $D_{\mathrm{M}}$ der Diffusionskoeffizient des merkurierten Acetons. Stellen wir $\left[\bar{i}_{\mathrm{k}} /\left(\bar{i}_{\mathrm{d}}-\bar{i}_{\mathrm{k}}\right)\right]^{2}$ in Abhängigkeit vom Produkt $\left[\mathrm{CH}_{3} \mathrm{COCH}_{3}\right]$. $\bar{i}_{\mathrm{k}} / \overline{\bar{d}}_{\mathrm{d}}$ für verschiedene Acetonkonzentrationen graphisch dar, so erhalten wir eine Gerade (Abb. 12), deren Neigung sich mit der Hydroxylionenkonzentration ändert. Im Konzentrationsbereich von $10^{-3}$ bis $10^{-2} \mathrm{M}$ Aceton in $1 \mathrm{M}-\mathrm{KOH}$ entspricht den experimentellen Werten eine Gerade (Abb. 12), die die Gleichung erfüllt:

$$
\left[\bar{l}_{\mathrm{k}} /\left(\bar{i}_{\mathrm{d}}-\bar{i}_{\mathrm{k}}\right)\right]^{2}=8 \cdot 10^{-6}+1,72\left[\mathrm{CH}_{3} \mathrm{COCH}_{3}\right] \cdot \bar{i}_{\mathrm{k}} / \bar{l}_{\mathrm{d}}
$$

\section{Merkurierung von Ketonen an der Quecksilbertropfelektrode}

Aus den Gleichungen $(8)$ und $(8 a)$ können wir nach Einsetzen der bekannten Werte die unbekannten Größen berechnen. Beim Einsetzen in Gleichung (8) haben wir in Analogie zu strukturverwandten Verbindungen für Aceton schätzungsweise den Diffusionsk Aceton $D_{M}=0,85 \cdot 10^{-5} \mathrm{~cm}^{2} \mathrm{~s}^{-1}$ gewähtt. Be Potenter

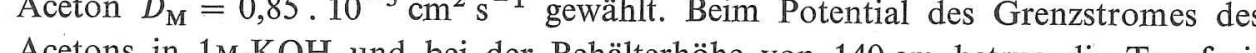
Acetons in 1 m-KoH und bei der Behalterhohe von $140 \mathrm{~cm}$ betrug die Tropfzeit $t_{1}=2,8 \mathrm{~s}$, die Ausflu.jgeschwindigkeit bei der gegebenen Höhe $m=3,0 \cdot 10^{-3} \mathrm{~g} \mathrm{~s}^{-1}$. Bei unseren experimentellen Bedingungen war dor hypothetische Diffusionsstron nach der IIlkovič-Gleichung durch die Beziehung $\bar{i}_{\mathrm{d}}=0,96 \cdot 10^{-3}\left[\mathrm{CH}_{3} \mathrm{COCH}_{3}\right] \mathrm{A}$ gegeben. Für die durch das Verhältnis

$\left[\mathrm{CH}_{3} \mathrm{COCH}_{2}^{-}\right]\left[\mathrm{H}_{3} \mathrm{O}^{+}\right] /\left[\mathrm{H}_{2} \mathrm{O}\right]\left[\mathrm{CH}_{3} \mathrm{COCH}_{3}\right]$

definierte saure Dissoziationskonstante der Ketoform des Acetons gibt Bell ${ }^{11}$ bei der Temperatur von $25^{\circ} \mathrm{C}$ den Wert $10^{-20}$ an. Für unsere Konstante $K$ ergibt sich hieraus

$\mathrm{K}=\left[\mathrm{CH}_{3} \mathrm{COCH}_{2}^{-}\right] /\left[\mathrm{CH}_{3} \mathrm{COCH}_{3}\right]=$ $=10^{-20} \cdot\left[\mathrm{H}_{2} \mathrm{O}\right] /\left[\mathrm{H}_{3} \mathrm{O}^{+}\right]=55 \cdot 10^{-6} \cdot\left[\mathrm{OH}^{-}\right]$

Abb. 12

Graphische Darstellung der Beziehung (8) für $2 \cdot 10^{-3}$

bis $10^{-2} \mathrm{M}$ Aceton in $1 \mathrm{~m}-\mathrm{KOH}$

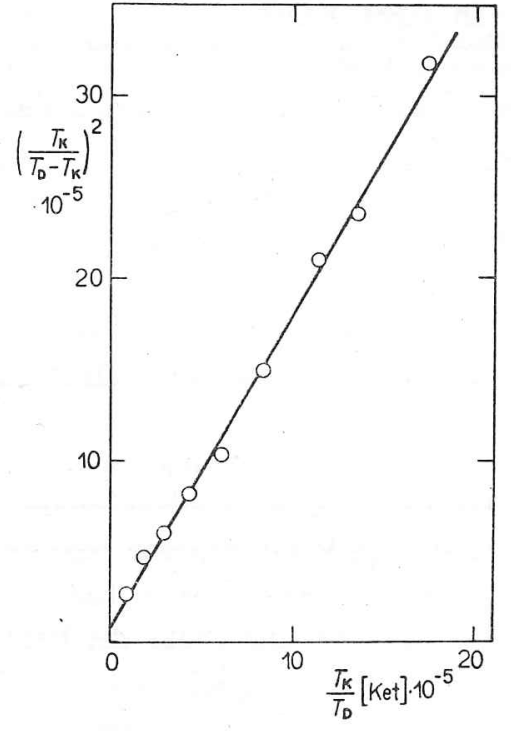

Aus den Gleichungen $(8)$ und $(8 a)$ erhalten wir nach Einsetzen für $k_{1}^{\prime}$ bei $1 \mathrm{M}-\mathrm{KOH}$ $k_{1}^{\prime}=8 \cdot 10^{-6} / 0,661 \mathrm{Kt}_{1}\left[\mathrm{OH}^{-}\right]=7,8 \cdot 10^{-2} \mathrm{~s}^{-1} 1 \mathrm{~mol}^{-1}=4,7 \mathrm{~min}^{-1} 1 \mathrm{~mol}^{-1}$.

Die Konstante $k_{1}^{\prime}$ sollte von der Laugekonzentration unabhängig sein. Zur Kontrolle haben wir die Messung noch in $0,8 \mathrm{M}-\mathrm{KOH}$ durchgeführt, wobei die durch die Experimentalpunkte durchgelegte Gerade der Gleichung entsprach:

$$
\left[\bar{i}_{\mathrm{k}} /\left(\bar{l}_{\mathrm{d}}-\bar{i}_{\mathrm{k}}\right)\right]^{2}=5 \cdot 10^{-6}+1,40 \cdot\left[\mathrm{CH}_{3} \mathrm{COCH}_{3}\right] \cdot \bar{i}_{\mathrm{k}} / \bar{l}_{\mathrm{d}}
$$

Durch den gleichen Vorgang haben wir aus diesem Versuch für $k_{1}^{\prime}$ den Wert 7,6 $.10^{-2} \mathrm{~s}^{-1} 1 \mathrm{~mol}^{-1}$ erhalten, der mit dem Ergebnis in $1 \mathrm{M}-\mathrm{KOH}$ gut übereinstimmt. Für di gleiche $\mathrm{K}$. Für die gleiche Konstante bei der Temperatur von $25^{\circ} \mathrm{C}$ geben Dawson und Spivey ${ }^{12}$ den Wert 7 min $^{-1} 1 \mathrm{~mol}^{-1}$ und Bell und Lidwell ${ }^{13}$ den Wert $15 \mathrm{~min}^{-1} 1 \mathrm{~mol}^{-1}$ an beide Werte wurden aus Messungen der Jodierungsgeschwindigkeit des Aceton gewonnen 
Den Wert der katalytischen Konstante $k_{1}^{\prime \prime}$ für $1 \mathrm{M}-\mathrm{KOH}$ erhalten wir aus dem zweiten Glied der Gleichung $(8 a)$

$$
\begin{gathered}
k_{1}^{\prime \prime}=1,72 / 0,661 \cdot K \cdot t_{1} \cdot\left[\mathrm{OH}^{-}\right] \cdot \sqrt{D_{\mathrm{A}} / D_{\mathrm{M}}}=1,7 \cdot 10^{4} / 1,13= \\
=1,5 \cdot 10^{4} \mathrm{~s}^{-1} \mathrm{1}^{2} \mathrm{~mol}^{-2} .
\end{gathered}
$$

Die Konstante $k_{1}^{\prime \prime}$ läßt sich auch durch Vergleich der oben angeführten empirisch gefundenen Beziehung mit dem theoretischen Näherungsausdruck für die Konzentrationsabhängigkeit des Grenzstromes berechnen. Auf diesem Weg ergibt sich für $\mathrm{M}-\mathrm{KOH} k_{1}^{\prime \prime}=1,45 \cdot 10^{4} \mathrm{~s}^{-1} 1^{2} \mathrm{~mol}^{-2}$

In 0,8M KOH-Lösung ist der für die Konstante $k_{1}^{\prime \prime}$ gefundene Wert etwas größer, und zwar $1,95.10^{4} \mathrm{~s}^{-1} 1^{2} \mathrm{~mol}^{-2}$. Diese Unstimmigkeit läßt sich wahrscheinlich dadurch erklären, daß die katalytische Aktivität des merkurierten Aceton bei höheren Laugekonzentrationen geringer ist. Derselben Ursache kann auch der ungewöhnliche Verlauf der Abhängigkeit der Stufenhöhe von der Laugekonzentration zugeschrieben werden (Abb. 2).

Die Erscheinung, daß die polarographische Stufe nur bis zu einem bestimmen Grenzwert mit der Zugabe des merkurierten Acetons wächst, läßt sich dadurch erklären, daß die Adsorption des Reaktionsproduktes an der Elektrodenoberfläche bei der großen Geschwindigkeit der gesamten Reaktion zu stören beginnt. Die gleiche Erscheinung tritt bei höheren Aceton- oder Laugekonzentrationen ein. Daß Organoquecksilberverbindungen leicht adsorbiert werden, ist schon aus der klassischen Polarographie bekannt ${ }^{14}$

Der resultierende Wert für die Dissoziationsgeschwindigkeitskonstante des Acetons zeigt, da $\beta$ dic Dicke der Reallionschicht ander Elekrode die Moletuldicesionen genïgend übersteigt, so $\mathrm{d} \beta$ es berechtigt war, fir die der Duchtittsealion vorgelagerte chemische kinetik zu benutzen.

Pedersen $^{15,16}$ hat festgestellt, daß die saure Dissoziation des Ketons durch Schwermetall-Ionen katalysiert wird. Es scheint, daß bei den Quecksilber-Ionen ein analoger Fall vorliegt; nach den polarographischen Ergebnissen wirkt wahrscheinlich der zwischen den Quecksilber-Ionen und dem Anion der Enolform des Keton ausgebildete Komplex katalytisch. Aus den bisherigen Resultaten lassen sich allerdings noch keine Schlüsse über den eingehenden Mechanismus der Katalyse ziehen; der Einfluß des Anions auf die Stufenhöhe deutet darauf hin, daß die katalytische Aktivität in beträchtlichem $\mathrm{Ma} ß$ von der Zusammensetzung des Komplexes abhängt.

Das Strommaximum auf der umgeschalteten Kurve erscheint im Potentialgebiet, in welchem die anodische Stufe der normalen Kurve beginnt, also bei Potentialen, bei denen die rückläufige Reaktion noch zur Geltung kommt (es handelt sich um eine reversible Stufe). In diesem Gebiet wird während beider Umschaltphasen eine gewisse Menge des katalytisch hoch wirksamen komplexen Kations an der Ellttrodenoberfäche encuert und so die Depolaristormenge erhöht. Bei negativeren Poten- tialen, bei denen die Rückreaktion bereits nicht mehr verläuft, werden in der „Arbeits-

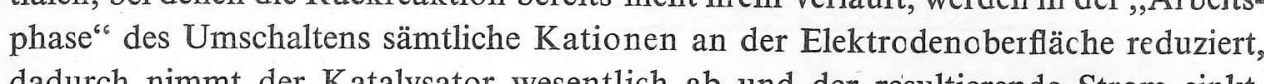
dadurch mentrodenoberfläche erneuert und entsteht.

Die übrigen Ketone unterliegen in ähnlicher Weise wie Aceton an der Tropfelektrode der Dissoziation und Merkurierung. Ketone, die keinen sauren Wassestoff enthalten, liefern keine polarographische Reaktion. Phenylisopropylketon ist wahrscheinlich aus sterischen Gründen polarographisch inaktiv.

Dr.O. Exner spreche ich für die Darstellung und die Zurverfügungstellung des merkurierter Acetons und zahlreicher Ketone sowie für die wertvollen Diskussionen meinen aufrichtigen Dank Arbeit.

Fräulein V. Skälová danke ich für die Anfertigung der Abbildungen.

Literatur

1. Rochow E. G., Hurd D. T., Lewis R. N.: The Chemistry of Organometallic Compounds,

2. Sidgwick N. V.: The Chemical Elements and their Compounds, S. 302. Oxford Univ. Press,

Heyrovský M.: Chem. zvesti 16, 338 (1962),

Kalousek M., Rálek M.: diese Zeitschrift 19, 1099 (1954); Chem. listy 48, 808 (1954).

. Nêmec L., Smoler I.: Chem. listy 51, 1958 (1957).

. Tha J. Im Buche: Progress in Polarography, Bd. 2, S. 383. Interscience, New York 1961.

Jenšovšký L.: Chem. Tech. (Berlin) 8,360 (1956)

8. Morton A. A., Penner M. P.: J. Am. Chem. Soc. 73, 3300 (1951).

9. Brdicka R.: diese Zeitschrift 20, 387 (1955); Chem. listy 48, 1458 (1954),

11. Bell R. P. Trans. Faraday Soc. 39, $253(1943)$.

12. Dawson H. M., Spivey E.: J. Chem. Soc. 1930, 2180

3. Bell R. P., Lidwell O. M.: Proc. Roy. Soc. (London) 176,88 (1940).

14. Benesch R. E., Benesch R.: J. Phys. Chem. 56, 648 (1952).

15. Pedersen K. J.: Acta Chem. Scand. 2, 252 (1948).

6. Pedersen K. J.: Acta Chem. Scand. 2, 385 (1948).

Übersetzt von H. Bažantovà.

Резюме

М. Гейро овский: Меркурирование кетонов на рпутпном капельном электроде. Кетоны дағо в щелочной среде анодную полярографическую волну, соответствующую образованию ртутноорганиеского сосдинения. Соответствующий ток управляется скоростью автокатализировании представления, что реакшией, определяюшей скорость меркурирования, является образование энольной формы кетона, из полярографических измерений рассчитана константа скорости энолизации ацетона, значение которой хорошо совпадает со значениями, приведенными в литературе и рассчитанными на основании измерения скорости галоидирования.

Vol. 28 

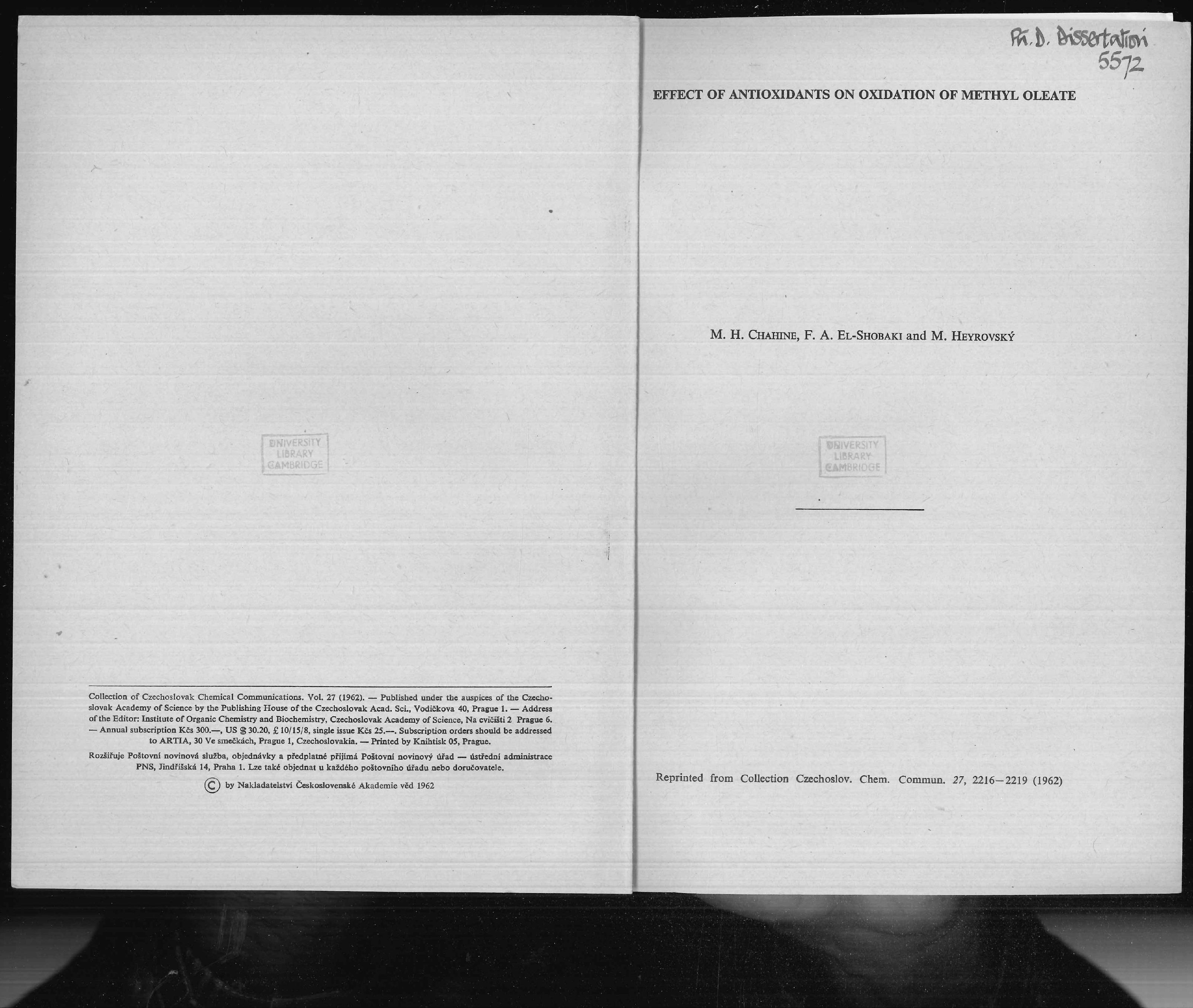
EFFECT OF ANTIOXIDANTS ON OXIDATION OF METHYL OLEATE M. H. Chahine, F. A. EL-Shobaki and M. HeYrovskY Whanal Research Centre, Cairo, UAR and Polarographic Institute, Czechoslovak Academy of Science, Prague

Received January .12th, 1962

It has been shown by Kuta and Quackenbush ${ }^{1}$ on their polarographic investigations an in oxidation of lard without changing gualitatively the types of thidants introduced a lag phase We have used the same methods to compare the protecting ability of various antion products. oxidation of methyl oleate, at $63^{\circ}$ and $100^{\circ} \mathrm{C}$.

\section{Experimental}

Materials

Methyl oleate was prepared by esterifying pure oleic acid (Merck) with methanol in presence of sulfuric acid ${ }^{2}$. The acid free, dry ester was subjected to fractional distillation under vasence The fraction which boiled at $166.8 \% 2 \mathrm{~mm}$ was collected (iodine number 85.4 ) and was stored

in a refrigerator.
The antioxidants 3,5-di-t-butyl-4-hydroxytoluene, butylated hydroxyanisole (mixture of
3-t-butyl-4-hydroxyanisole by Eastman, Kingsport, tocopherols in equal proportions in addition to small amounts of $\beta$ and $\delta$ forms)
Notes

ed by Distillation Products Industries, Rochester, N. Y., USA. Gossypol was prepared from butanone extracts of cottenseed, as described by King and Thurber ${ }^{3}$ and purified by crystalliz ation from diethylether and xylene. Crystalline gossypol melted at $184^{\circ} \mathrm{C}$, For $\mathrm{C}_{30} \mathrm{H}_{30} \mathrm{O}_{8}(518.0)$ calculated $69 \cdot 42 \% \mathrm{C}, 6 \cdot 05 \% \mathrm{H}$; found $69 \cdot 48 \% \mathrm{C}, 5 \cdot 83 \% \mathrm{H}$. Dianilinogossypol was prepared a described by Clark. After repeated crystallization from benzene, free of thiphene, it melted at $302^{\circ} \mathrm{C}$. $\mathrm{For}_{42} \mathrm{C}_{42} \mathrm{H}_{40} \mathrm{~N}_{2} \mathrm{O}_{6}$

Kinetic Measurements

Each of the tested antioxidants was incorporated at a concentration of $0.05 \%$ in $70 \mathrm{~g}$ of peroxide free methyl oleate by the aid of $10 \mathrm{ml}$ of anhydrous diethyl ether; in case of dianilinogossypo

The test tubes containing the examined ester were immersed in a thermostated paraffine oil bath. The oxidation reaction was conducted by bubbling oxygen at a constant rate through the
reaction mixture. In the experiment performed at $100^{\circ} \mathrm{C}$ which lasted 165 hours a $2 \mathrm{ml}$ sample was withdrawn every three hours from each test tube. At $63^{\circ} \mathrm{C}$ a $1 \mathrm{ml}$ sample was being taken twice a day for about 900 hours.

Analytical Method

The peroxide value, expressed in milliequivalents per kilogram, was determined as follows ${ }^{6}$. A weighed sample $(0.2 \mathrm{~g})$ was placed in a stoppered flask, flushed with carbon dioxide, and dissolved in $25 \mathrm{ml}$ of a mixture of chloroform-acetic acid $(2: 3)$. After swirling for two minutes of distilled water were added and the liberated iodine was immediately titrated with $0.01 \mathrm{~N}$ $\mathrm{Na}_{2} \mathrm{~S}_{2} \mathrm{O}_{3}$

The polarographic procedure was essentially that described by Kuta and Quackenbush ${ }^{1}$ Polarograms of samples of oxidized methyl oleate were obtained using a $0 \cdot 3 \mathrm{M}$ solution of LiC in a methanol-benzenge mixture (1: 1$)$. Conducting the analyses at $63^{\circ} \mathrm{C}$ we had to incorporate $0.01 \%$ ethylhydroxycellulose into the solution in order to suppress maxima; after recording the polarographic curve of the deaerated $5 \mathrm{ml}$ or blank solltion $009 \mathrm{~g}$ of sample was added, curve was taken. At $100^{\circ} \mathrm{C}$ no maximum suppressor was necessary and $0.19 \mathrm{~g}$ of sample were taken. The polarograms were obtained on

a Radiometer polarograph PO 3 .

Fig. 1
Polarographic Curve of Oxidised Methyl Oleate

$15 \mathrm{ml}$ of blank solution, 2 added $0.095 \mathrm{~g}$ after 241 hours of oxidation. From $E=0$ sens. $=1: 5000$

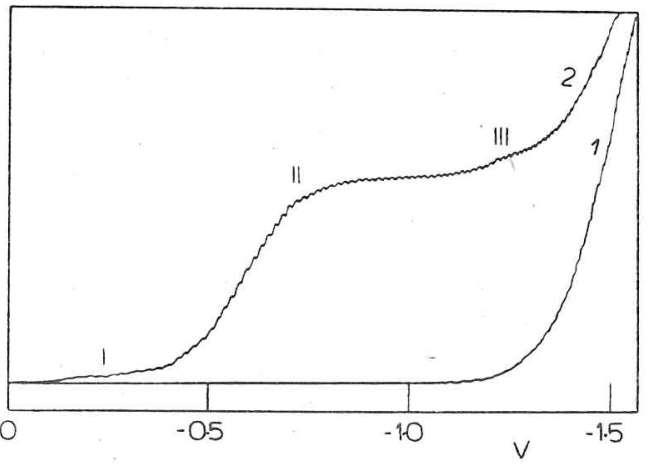

Results und Discussion

The polarographic curves of autoxidized methyl oleate are of the type shown on Fig. 1. The reduction wave $\mathrm{I}$, which appears from the beginning of oxidation together with the wave II (comp. Fig. 1), by werche ghly abon to 
pounds ${ }^{7,8}$. Wave II, most prominent during the whole process, is due to the prevailing primary oxidation product, a mixture of the isomers of methyl hydroperoxide oleate ${ }^{7,9,10}$. The heigh After the maximum of pand was found to show the same general trend as the peroxide values. a third wave III, indicating presence of further oxidation products in the mixture, probably of unsaturated aldehydes ${ }^{7}$. The shape of polarographic curves in pure oxidized methyl oleat does not differ from those obtained in presence of any of the antioxidants examined, which The course of oxidation is representen on Fis. 2 and 3 showing the sil

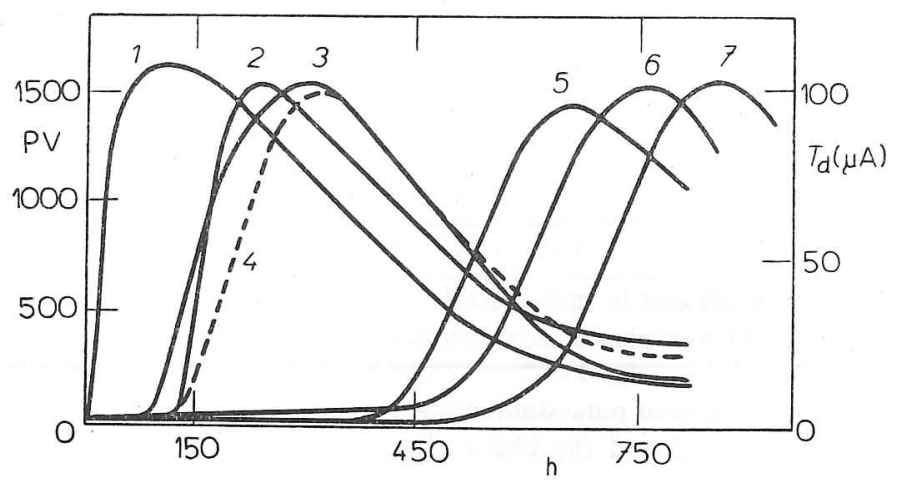

Fig. 2
Peroxidic Values (P. V.) and Heights of Polarographic Hydroperoxide Wave during Oxidation
at $63^{\circ} \mathrm{C}$ Pure methyl oleate, 2 methyloleate and gossypol, 3 methyl oleate and mixed tocopherols, 4 methyl oleate and dianilinogossypol, 5 methyl oleate and propylgallate, 6 methyl oleate and butylated hydroxyanisole, 7 methyl oleate and 3,5-di-t-butyl-4-hydroxytoluene.

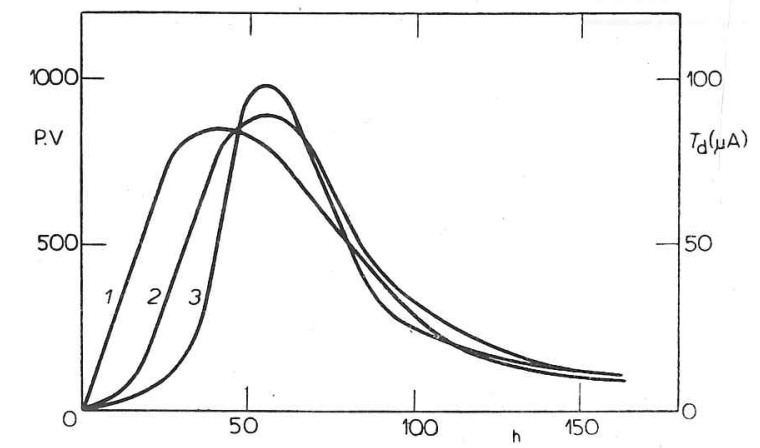

Fig. 3
Peroxidic Values (P. V.) and Heights of Polarographic Hydroperoxide Wave during Oxidation at $100^{\circ} \mathrm{C}$
Pure methyl oleate, 2 methyl oleate and properoxide Wave during Oxidation anisole.
At $63^{\circ} \mathrm{C}$ (Fig. 2) there is a considerable difference in the induction periods of the pure methyl oleate and methyl oleate with antioxidants, and moreover various antioxidants increase the induction period in various extent. The difference between the two groups of curves with antioxidant in molar concentrations; the same weight of antioxidants being taken the ligher ones are more concentrated, and hence more effective in removing free radicals. But within these groups of curves the cause of the differences has to be sought in the specific activity of each antioxidant. At $100^{\circ} \mathrm{C}$ (Fig. 3) the peroxide curves do not differ much from each other. Even here the shortes induction period appears with antioxidants of higher molecular weight, but the differences are small. This might be explaner by heratures other oxidation mechanisms have to be taken into consideration (as direct reaction of oxygen with the double bound ${ }^{11}$ ), where the antioxidants play no role.

References

1. Kuta E. J., Quackenbush F. W.: J. Am. Oil Chemists' Soc. 37,148 (1960).

1. Hilditch T. P. The Chemical Constitution of Natural Fats. Chapman \& Hall, London 1947. 3. King W. H., Thurber F. H.: J. Am. Oil Chemists' Soc. 30,70 (1953).

4. Clark E. P.: J. Biol. Chem. 76, 229 (1928).

. King W. H., Thurber F. H.: J. Am. Oil Chemists' Soc. 33, 169 (1956).

Tollenaar F.D.. Ceniral Institute for Nutrition Research T.N. O., Utrecht, Report No. R307 E

. Chem.

Soc. 75, 3135 (1953). Chemists' Soc. 30,420 (1953)

Swift C. E., Dollear F. G., O’Connor R. T.: Oil \& Soap 23, 355 (1946)

11. Gunstone F. D., Hilditch T. P.: J. Chem. Soc. 1945,836 ,

Резюме

М. Г. Чахин, Ф. А. Эл-Шобаки и М. Гейровский: Влияние антиоксидантов на окисле-

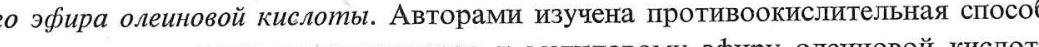
при 63 и $100^{\circ} \mathrm{C}$. 


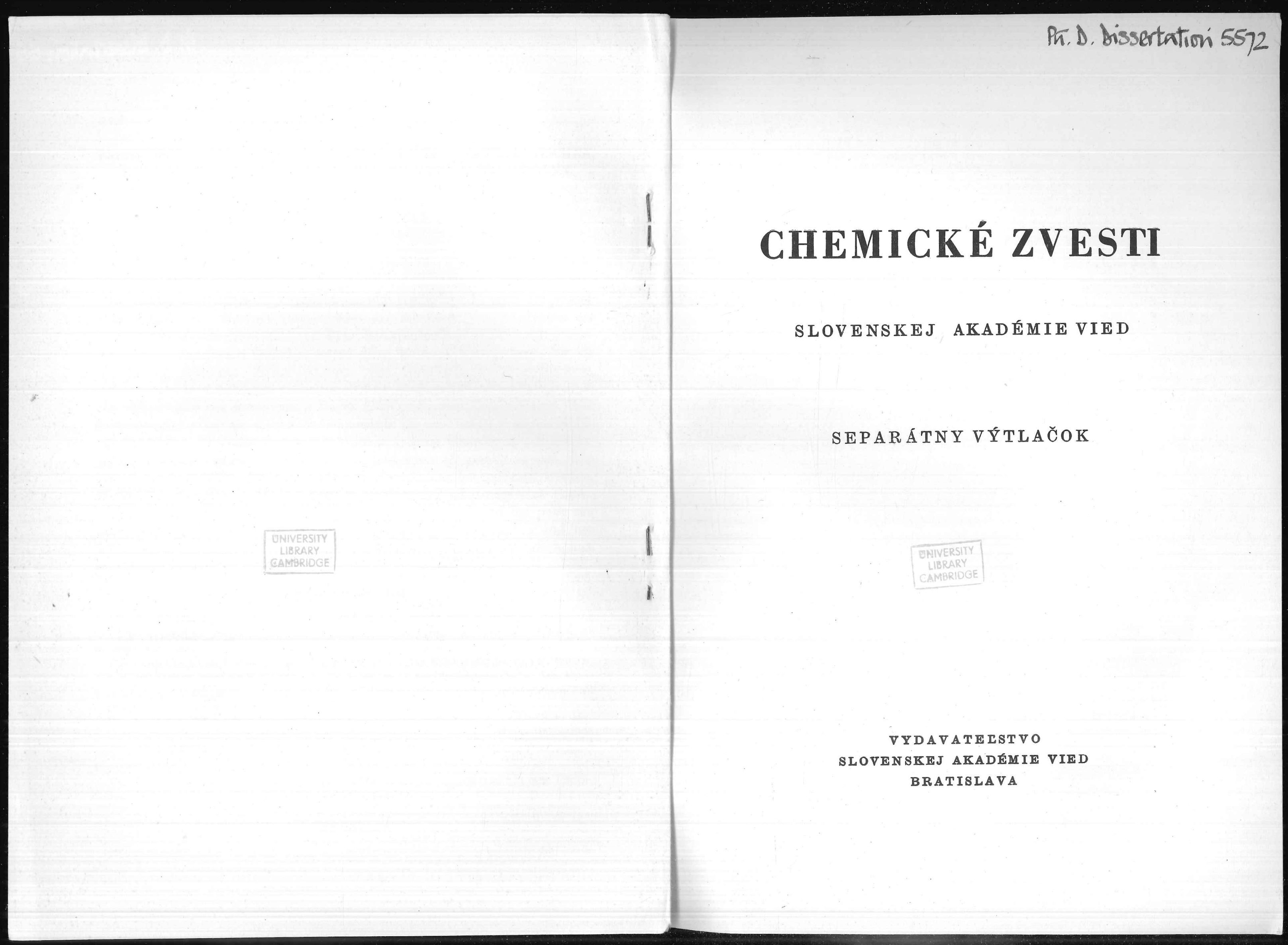


Organische Elektrochemie, Dresden 1942, 227. - 10. Heyrovský J., Kalvoda R.

Oszillographische Polarographie, Berlin 1960, 87.
11. Kalvoda R., Mackú J., Micka K., Z. phys. Chem. (Leipzig) Sonderheft 66 (1958). 12. Vogel J., bisher nicht veröffentlicht. - 13. Kalvoda R., Mackủ J., Collection 21, 493 (19.0 Chem. listy 46, 129 (1952). - 16. Rice F. O., Evering B. L., J. Am. Chem. Soc. 56, 2105 (1934).

Dr. Robert Kalvoda, Praha 1, Vlašská 9, Polarografický ústav ČSAV.

Diskussionsheiträge

J. Dévay fügt zu, dass man viellieht durch die Erhöhung der Wechselstromfrequen $z$ die Bildungsgesehwindigkeit des Artefaktes feststellen könnte. 
OSZILLOPOLAROGRAPHISCHES VERHALTEN DER KETONE IN ALKALISCHEN LÖSUNGEN

MICHAEL HEYROVSKÝ

Polarographisches Institut an der Tschechoslowakischen Akademie der Wissenschaften in Praha

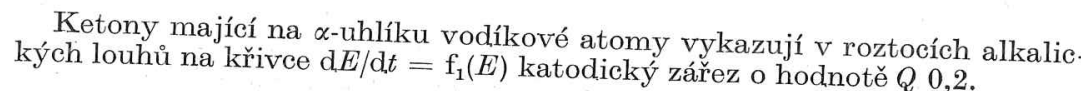

Bei der Polarisation der Quecksilbertropfelektrode mittels Wechselstrom in Ketone in Konzentrationen der Ordnung 10-4 $w$, je nach ihrer Adsatigten nur Kapazitätseffekte auf. Der an die Ketogruppe Kern bringt in die oszillopolarographische Ablet gematische tätseinschnitten noch elektrolytische Fins Ableitungskurve zu den Kapazi-

entsteht auf der J. Heyrors $\dot{y}$ [2] Ketoverbinder halten halten, charakteristisch ist, wurde die Reaktion näher untersucht.

\section{Experimenteller Teil}

Oszillopolarographische Messungen wurden mit dem Polaroskop P 576 und mit einem Elektrode wurde dis Quecksilbertropfen nach J. Vogel verwendet Qur Verfolektrode und der hängende Kurven diente der Polarograph V 301 und der Polar Verfolgung der polarographischen Als Grundelektrolyt wurden wëssrige und wingrig äth und $\mathrm{NaOH}$ der Reinheit p. a benutzt. Die Ketoverbindungen w wure Losungen von KOH gereinigt; Aceton zweimal mit Kaliumpermanganat destilliert wurden durch Destillation

\section{Ergebnisse und Diskussion}

Aceton bildet auf der $\mathrm{d} E / \mathrm{d} t=\mathrm{f}_{1}(E)$-Kurve einen irreversiblen kathodischen Einschnitt der Launer etwa 0,2. Das Erscheinen dieses Einschnittes hängt von der Konzentration tration des Acetons 0,2 r in In einer 0, 1 M Lauge ist der Einschnitt von der Konzen$2.10^{-2} \mathrm{M}$ messbar. Mit Erhöhung der Kon $5.10^{-2} \mathrm{M}$ (Abb. 1) und in 5 M Lauge von tiefer; in 1 м Lauge und 0,25 m Aceton entsteht neben des Acetons wird der Einschnitt Einschnitt von $Q$ etwa 0,1. Dabei erscheinen auch Ausbuchtinen positiverer kleiner veränderung der Differentialkapazität. Die beiden Einschnitte hën der Kurve wegen

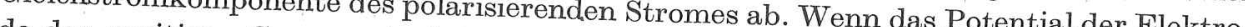
den positiven Grenzwert, d. h. die elektrolytische Auflösung des Quecksilbers unter der Bildung von Quecksilber(II)oxyd, nicht erreicht, verschwinden die Einschnitte (Abb. 2). Diese Wirkung ist nur in konzentrierteren alkalischen. Lösungen zu beobachten; in neutralen oder sauren Milieu kommen diese positiven kathodischen Einschnitte nicht vor. Völlig analog ist das Verhalten der hoheren Acetonhomologe: es wurden Methyläthylketon, Diäthylketon, Methylisopropylketon, Metyl-n-hexylketon und Methyl-

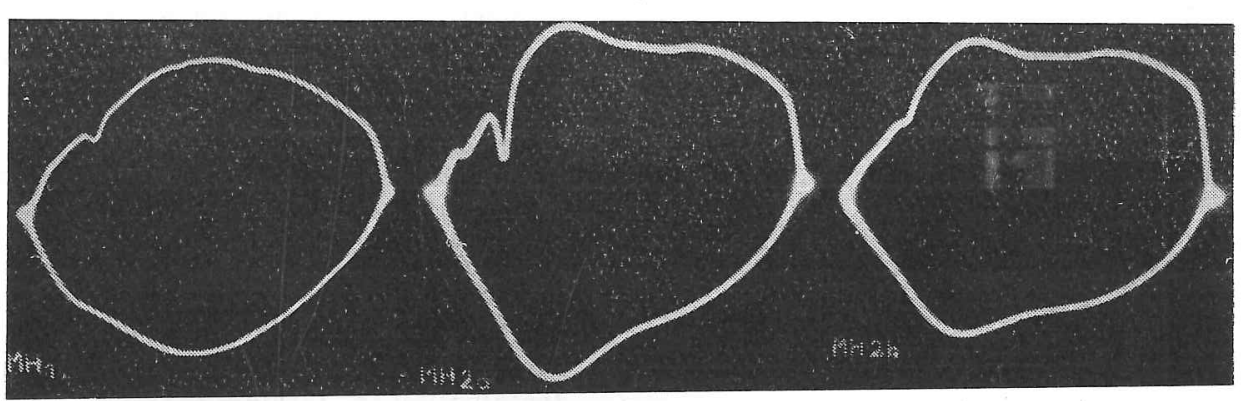
Abb. 1. $\mathrm{d} E / \mathrm{d} t=\mathrm{f}_{1}(E)$-Kurve von $0,1 \mathrm{M}$-Aceton in $1 \mathrm{M}-\mathrm{KOH}$. - Abb. $2 . \mathrm{d} E / \mathrm{d} t=\mathrm{f}_{\mathrm{f}}(E)$ -
-Kurve von $0,25 \mathrm{MA}$ Aceton in $1 \mathrm{M}$-KOH. $\mathrm{M}$ ) die Elektrode ist polarisiert im ganzen Poten
tialbereich; $b$ ) das Potential der Elektrode erreicht nicht völlig den positiven Grenzwert. schnitte von $Q \quad 0,2$ und 0,1 , die mit dem positiven Grenzpotential verbunden sind; be
den grösseren Molekülen der Ketone ist hier die Kapazitätswirkung viel stärker als bei Aceton ausgeprägt.

Dieselben Einschnitte erseheinen auf der Kurve von Cyclopentanon und Cyclohexanon (Abb. 3), Diacetonalkohol (Abb.4), Mesityloxyd und Phenylaceton in beinahe den-

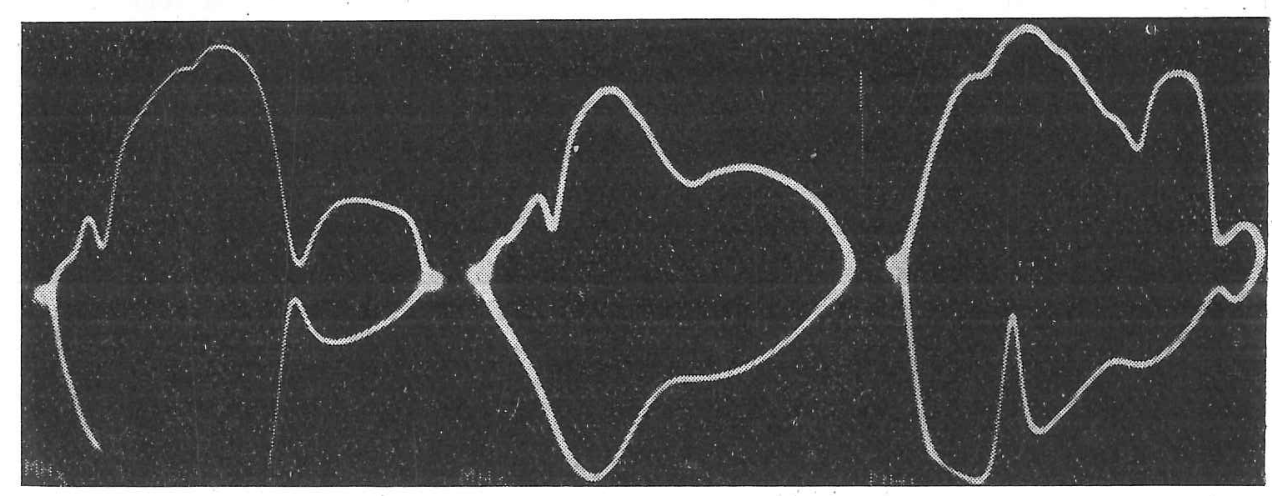

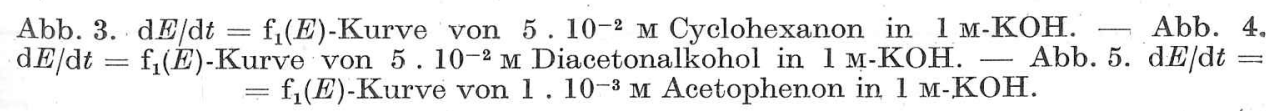

Propiophenon, Butyrophenon sind in millinormalen Lösungen neben grossen elektro

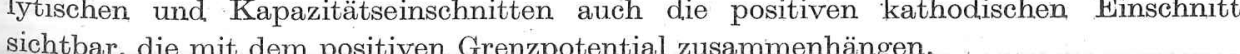


Auch verschiedene Ketosäuren, wie Brenztraubensäure (Abb. 6), Phenylbrenztrauben säure und Lävulinsäure geben neben anderen auch die für die Ketogruppe charakte-
ristischen Einschnitte, ristischen Einschnitte.

Acetylaceton als Diketon unterscheidet sich von den Monoketonen verschieden in der

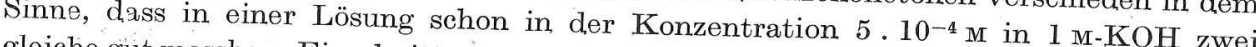
0, 27 und 0,49 entstehen (Abb. 7). Das Vor-

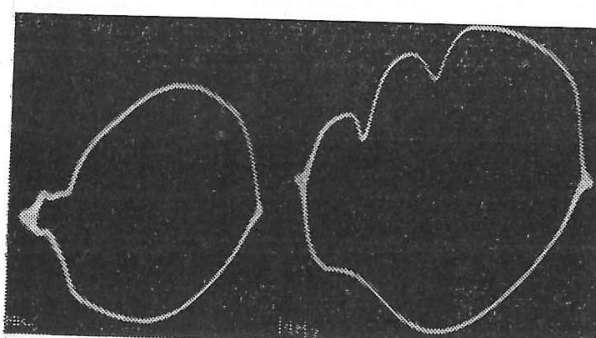
negative Grenzpotential ist durch Redul tion. der Brenztraubensäure gegeben.)
Abb. 7. d $E /$ d $t=f_{1}(E)$-Kurve von $1.10^{-3} \mathrm{M}$
Acetylaceton in $1 \mathrm{M}$-KOH.
Abb. 6. $\mathrm{d} E / \mathrm{d} t=\mathrm{f}_{1}(E)-$ Kurve von $5 \cdot 10^{-2}$
M Brenztraubensäru in $1 \mathrm{M}$-KOH. kommen beider Einschnitte ist wieder durch das Erreichen des positiven Grenzpotentials bedingt.

Mit Phenylisopropylketon, Benzalde. hy, Benzophenon, Phenylglyoxalsäure, typischen Finschnits in konnten die trationsverhältnis beobachtet werdenzenNeben Ketonen bilden aush enige Amide (Harnstoff, Acetamid, Urethenige der alkalischen Lösung auf der Ableitungskurve irreversible kathodische Einschnitte, die auch von dem positive Grenzpotential abhängen. Dagegen weis Kalilauge kere Wir Ableitungskurve in

Auf den polarographisehen Kurven aller dor Verbung lischen Lösungen anodische Stufen bei etwa dieser Verbindungen erscheinen in alkaMessungen [3] erklären diese Stufen bei positiven Potentialen durch das Aufäsen Quecksilbers unter Bildung einer Organoquecksilberverbindung. Diese Hypothese wird in Alkalibut Dor in Keto-Form inurierung unterliegen die Ketone in ihrer enolischen Form [4], die mit de zentration der Fnol-Form Lösungen im Gleichgewicht steht. Die Gleichgewichtskonim Gebiete von Prozenten und Bruchteilen der Proz der Grundlösung, liegt aber immer Dadurch wird die scheinbare kleine Empfindlichteit der polytischen Konzentration. erklärt.

Bei der Polarisation der Elektrode durch Wechselstrom ist auf der Ableitungshurve die anodische. Bildung der Organoquecksilberverbindungen nicht zu Ableitungskurve sie sich zu nahe dem positiven Grenzpotential abspielt, bei dem sich beobachten, weil auföst. In der folgenden kathodischen Phase wird das Quecksilber aus den Produkten der anodischen Merkurierung wieder reduziert.

dass dache mit dem Kalousek-Umschalter und mit dem hängenden Tropfen zeigen, reduziert wird. Fs Pondentialen der anodischen Stufe entstandene Produkt reversibel ( mit der Gruppe $[-\mathrm{C}-\mathrm{C}-\mathrm{Hg}]^{+}$. Falls man aber die Elektrode zu noch positiveren Potentialen polarisiert, entstehen auf ihrer Oberfläche unter der Wirkung von Quecksilber II)hydroxyd, bzw. -oxyd. Verbindungen, in denen das Quecksilber fester gehalten wird, voraussichtlich in der Gruppe $-\|_{0}^{-}-C_{-}^{-}-\mathrm{Hg}-\mathrm{O}-$. Die Reduktion dieser Bindungen

verläuft dann irreversibel, bei negativeren Potentialen. Diese Reduktion entsprich den Einschnitten auf den oszillopolarographischen, Ableitungskurven. Die Einschnitte entstehen bei verschiedenen Substanzen bei demselben Potential, was auf Reduktio

Wegen geringer Empfindlichkeit ist die beschriebene oszillopolarographische Reaktion Sie könnte aber vielleicht als konstitutioneller Beweis für die Ketone) nicht geeignet. stoffatomen am $\alpha$-Kohlenstoffatom dienen, gleich wie es für die chemische Reaktio dieser organischen Substanzen mit der alkoholischen Lösung von Quecksilber(II)chlorid und Natriumethoxyd, vorgeschlagen wurde [5].

Herrn Dr. O. Exner bin ich für die Darstellung zahlreicher Verbindungen und für
wertvolle Diskussionen verbunden; Herrn Dr.P. Zuman gebiihrt mein Dank für die Überlassung einiger Ketoderivate.

Retoverbindungen, die am $\alpha$-C-A tom Wasserstoffatome enthalten, bieten in Ketoverbindungen, die am $\alpha$-C-Atom Wasserstoffatome enthalten, bieten in ve vom $Q 0,2$. Dieser Einschnitt hängt mit der Bildung einer Organoquecksilve vom $Q 0,2$. Dieser Einsc
berverbindung zusammen.

ОСЦИЛЛОПОЛ ЯРОГРАФИЧЕСКОЕ ПОВЕДЕНИЕ КЕТОНОВ В ЩЕЛОЧНЫХ РАСТВОРАХ

МИХАЕЛ ГЕЙРОВСКИ

Полярографический институт Чехословадкой академии на ук в Праге

Кетоны, имеюпие на $\alpha$-углероде водородные атомь, дают в растворах едких щелочей на кривой $\mathrm{d} E / \mathrm{d} t=\mathrm{f}_{1}(E)$ катодный зубец со зна чением $Q 0,2$

\section{LITERATUR}

1. Molnár L., Dissertation, Chemisches Institut der Slowakischen Akademie der

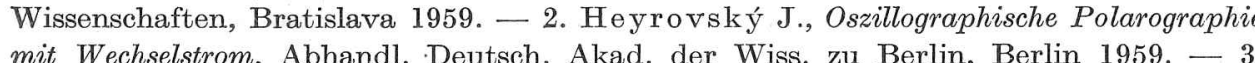
Heyrovský M., bisher nicht veröffentlicht. - 4. Rochow E. G., Hurd D. T., Lewis R. N., The Chemistry of Organometallic Compounds, New York 1957, 112. - 5. Connor R. van Campen J. H., J. Am. Chem. Soc. 58, 1131 (1936).

Dr. Michael Heyrovský, Praha 1, Vlašskká 9, Polarografický uistav ČSAV.

Diskussionsbeiträge

P. Zuman ist der Meinung, dass es sich wahrscheinlich bei der Reaktion der Amide mit dem Quecksilber um eine Bildung von Chelatverbindungen handelt.

M. Heyrovský ergänzt, dass beim Verfolgen des Mechanismus der oszillopolarographischen Elektroreduktionen bei extrem positiven oder negativen Potentialen immer noch eine andere polarographische Methode herangezogen werden muss. 


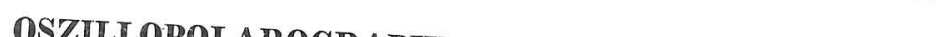

HYDROLYTISCHEN UND PHOTOLYTISCHEN VOLLETROLYTISCHEN, HERMANN BERG

Institut für Mikrobiologie und experimentelle Therapie Jena
dər Deutschen Alogemis

der Deutschen Akademie der Wissenschaften zu Berlin

U. sloučeniny typu etyleniminobenzochinonu (Bayer E-39) je sledován
prüběh elektrolytických, hydrolytických a fotolytických reakci.

Gegenüber der Gleichspannungspolarographie ermöglicht die oszill. Polarographie mit Wechselstrom häufiger den Nachweis von Przillographische Durchtrittsreaktion sowie von kurzlebigen Reaktanten im Von Produkten der reaktionen. Aus diesen Gründen wurde diese Method in verlauf von LösungsAufklärung mehrerer Folgereaktionen von Äthylenimino-Bogen für die insbesondere des 2,5-Bis-(äthylenimino)-3, 6-bis-( $n$-proplenimino-Benzochinonen, $(I)$, einem unter der Bezeichnung Bayer E-39 bekopoxy)-benzochinons- $(1,4)$ Polarogramm weist die reversible Chinonstu $\mathrm{pH} 7)$ und bei $-1 \mathrm{~V}$ eine irreversible Welle auf, $\left(E_{1 / 2}=-0,23 \mathrm{~V}\right.$ gegen NKE, gig ist $[1,2]$. Es konnte durch präparative auf, deren Grenzstrom $\mathrm{pH}$-abhännur die protonisierten Äthylenimino Im Oszillopolarogramm $\mathrm{d} E / \mathrm{d} t=f(E)$ ppen nacheinander reduziert werden. tialbereich eine $L$-förmige $f_{1}(L)$ findet man in diesem negativen PotenPotentialen drei reversible Änderungen durch hydrolytisohe erscheinen [1]. Thre Ursachen und ihre oder photolytische Reaktionen sollen ihre

\section{Experimenteller Teil}

Die Oszillogramme wurden mit dem Poitrortion

der Potentialachse aufgenommen, so dass überwiegen 574 unter grösster Dehnung im Bild erscheint.
Die Grundlösungən bastanden aus

mit einem Gehalt von $0,6 \mathrm{M}$-Nan $\mathrm{Na}_{2} \mathrm{SO}_{4}$ Phosphatpuffer oder Schwefelsäure $(0,1 \mathrm{~N}, 0,01 \mathrm{~N})$ zentrationen des Bayer E-39 lagen zwischen $5 \cdot 10^{-5}$ M und $5 \cdot 10^{-4}$ ststandes. Die KonTemparierbarundlösungen $10 \%$ Vol. Methanol. (B)

(Bodenquecksilber) wqecksiber), für die strömende Elektrodie Tropfelektrode eine Hg-Brèner [6]. Vergleichspol

meter SP 700 oder dom Zeiss-Monochrom LP 55, Absorptionsspektren mit dem Photo-

Ergebnisse 


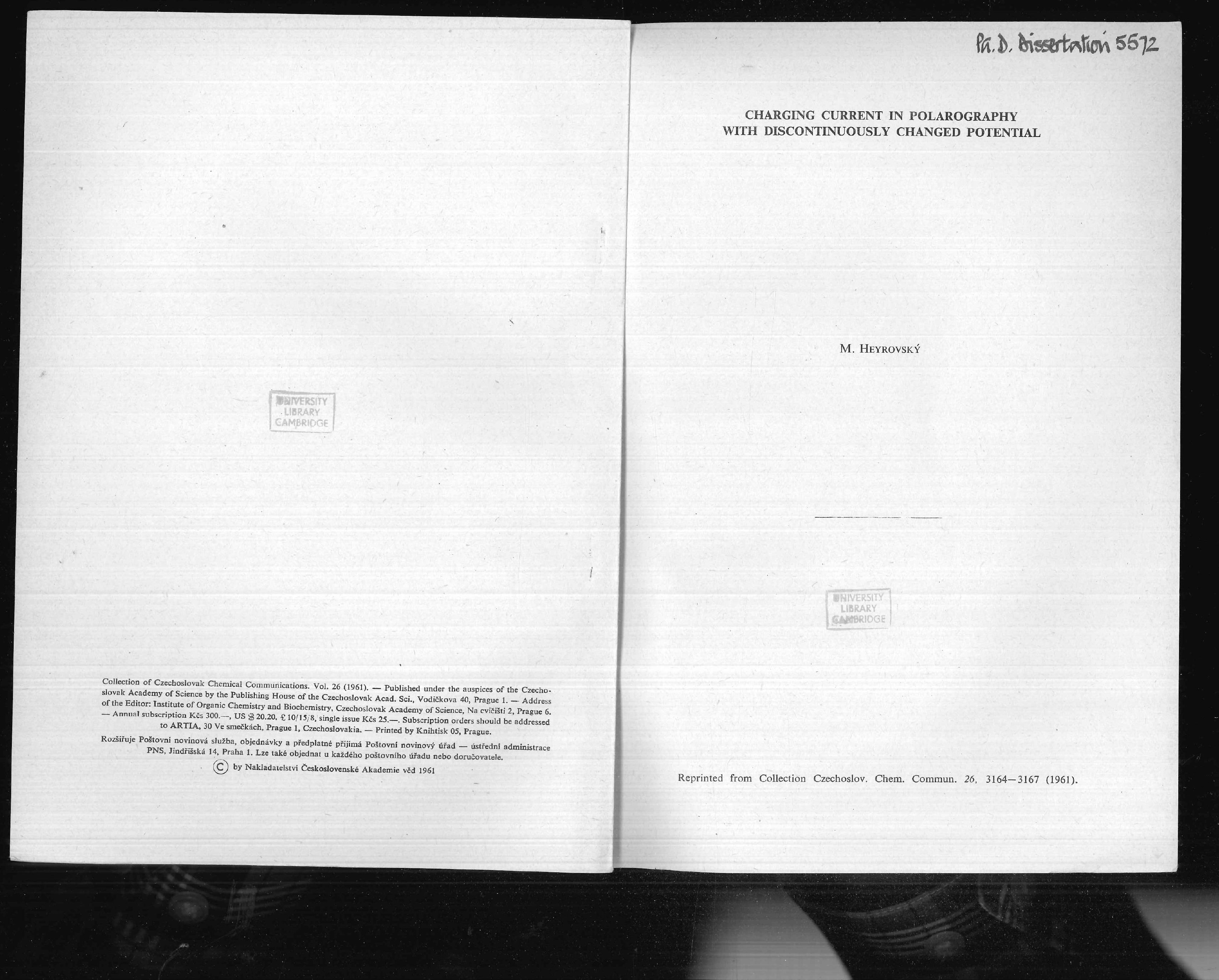


current obtained with the switch.* It can be expected that because of the repeated charging of the electrode to different potentials during the drop-life, the charging current will be much higher than in ordinary polarography, and that changes of capacity of the electrode double layer due rent, comparable with polarographic reduction or oxidation waves. In order to distinguish the mean charging current from the mean electrolytic cur-

rent obtained with the switch an expression for the charging current has been deduced and checked experimentally.

Fig. 1

Instantaneous Charging Current During two Periods of Commutation and the Mean Current $i_{\mathrm{T}}$ Dotted lines indicate current not recorded by the galcurrent not
vanometer.

$$
\text { Theoretical }
$$

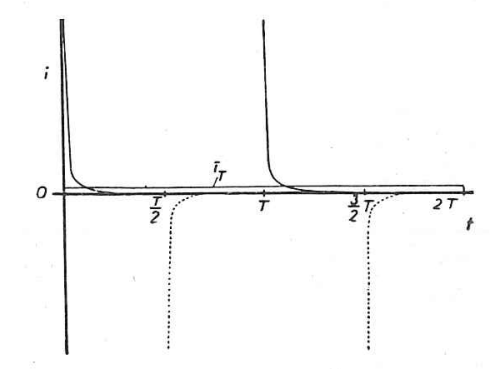

The electrode is charged with a periodic rectangular voltage of frequency $f$ from an auxiliary potential $E_{\mathrm{A}}$ to potential $E$ (given by the position of the sliding contact on the potentiometer of the polarograph) in the first half of the period $T(T=1 / f$ and back in the second half-period, the current being recorded by the galvanioter only during one half-period; this approximaThe capacity of the electroce cis cons change of the electrode surface during one half-period, is negligible $i$. e. with higher frequencies of commutation, especially towards the end of the drop life. The instantaneous current charging the electrode in the first half-period is given by the formula

$$
i=\frac{\Delta E}{R} \exp \left(-\frac{t}{R C}\right)
$$

where $\Delta E=E-E_{\mathrm{A}}$ and $R$ is the total resistance of the p

$$
i_{\mathrm{T}}=\frac{1}{T} \int_{0}^{T / 2} \frac{\Delta E}{R} \exp \left(-\frac{t}{R C}\right) \mathrm{d} t=f \Delta E \cdot C-f \Delta E \exp \left(-\frac{T}{2 R C}\right)
$$

Since under polarographic conditions the second term is negligibly small, the equation for the mean current in one period becomes

$$
i_{\mathrm{T}}=f . \Delta E . C
$$

To obtain the mean current during the whole drop life $t_{1}$, we replace the term $C$ in the equation (2) by the product of specific capacity $C_{1}\left(\mathrm{~F} \mathrm{~cm}^{-2}\right)$ and mean surface of the dropping electrode ing current recorded polarographically with the Kalousek's switch is given in absolute units as $i=0.51 \cdot f \cdot \Delta E \cdot C_{1} \cdot m^{2 / 3} \cdot t_{1}^{2 / 3}$ Experimental

The polarographic method of dicsontinuously changed potential using the switch of Kalousek is currently used for the investigation of electrode processes: it shows the degree of reversibility, helps to identify the reaction products and may indicate adsorption of the depolarizer ${ }^{2}$. An equation was deduced for the mean electrolytic current ${ }^{3}$, but no paper has yet dealt with the charging

All chemicals used were reagent grade (pro analysi). Curves were recorded using an electronic switch constructed according to Rálek and Novák $k^{4}$ in conjunction with the Model V 301 polaro-

* Matsuda ${ }^{8}$ calculated from a general equation the mean alternating charging current for polarography with a superimposed square-wave voltage of a small amplitude.
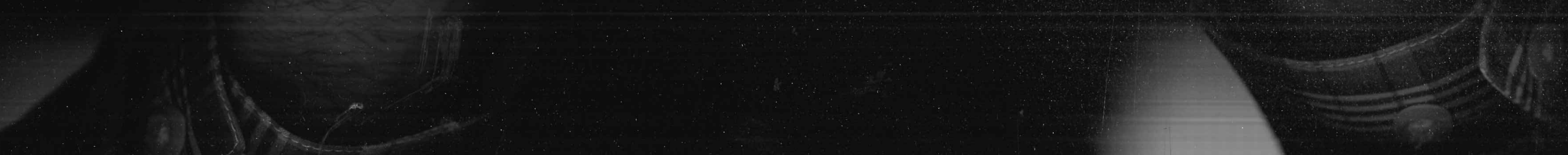
graph. The switch worked with frequencies $2 ; 2 \cdot 6 ; 3 \cdot 5 ; 4 \cdot 9 ; 8 \cdot 8 ; 11 ; 15 \cdot 4 ; 19 ; 21 \cdot 8 ; 30$ and $39 \cdot 8 \mathrm{cs}^{-1}$

\section{Results and Discussion}

The validity of eq. (2) was proved by joining a condenser of $0 \cdot 25 \mu \mathrm{F}$ and $1 \mu \mathrm{F}$ to the apparatus instead of the electrolytic cell and registering the resulting current. The obtained straight lines fitted the equation (2) within the limits of experimental error (about 3\%, mainly due to inconstancy
of frequency) in the whole available range of frequencies. Equation (3) was checked using pure $0 \cdot 1 \mathrm{M}$ solutions of $\mathrm{KCl}, \mathrm{Na}_{2} \mathrm{SO}_{4}, \mathrm{HCl}$ and $\mathrm{NaOH}$.

Like in ordinary polarography the charging current of a pure supporting electrolyte obtained

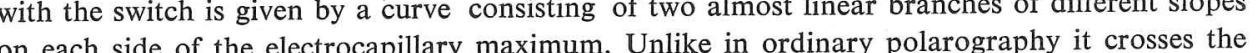
galvanometer zero line at the potential at which the difference $\Delta E$ of the commutated potentials becomes zero. In accordance with the formula the current was found to increase linearly with the frequency of commutation in all examined solutions within the whole frequency range. According to (3) the current should be independent of the pressure of mercury, which was also found

to be the case.
After substituting known and experimentally measured quantities into equation (3) we may calculate the specific capacity $C_{1}$. The resulting values obtained from the negative branfhes $0.1 \mathrm{~m}-\mathrm{KCl}$ and $17 \cdot 1 \mu \mathrm{F} / \mathrm{cm}^{2}$ for $0.1 \mathrm{M}-\mathrm{Na}_{2} \mathrm{SO}_{4}$. These data do not differ much from integral capacities given in literature ${ }^{5,6}$.

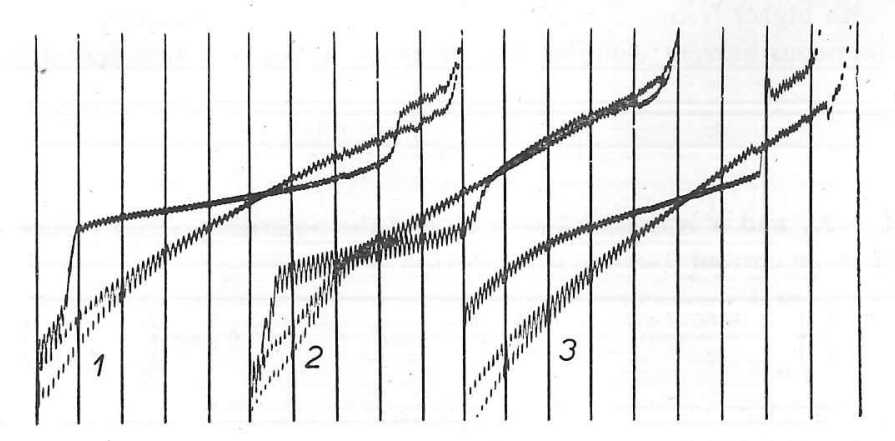

Fig. 2

ince of $\mathrm{S}$

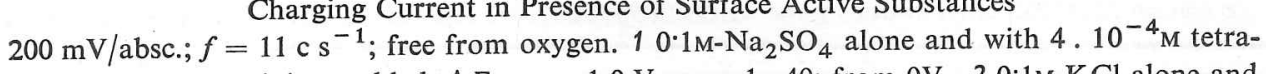
butylammonium sulphate added; $\Delta E_{0}=-1 \cdot 0 \mathrm{~V}$; sens. 1:40, from $0 \mathrm{~V} .20 . \mathrm{M}$-KCl alone and with $0.25 \mathrm{M}$ pyridine added; $\Delta E_{0}=-1 \cdot 2 \mathrm{~V}$; sens. $1: 30$; from $-0.2 \mathrm{~V}$.

The presence of surface active substances in aqueous solutions is marked on the curves by a decrease of the absolute value of charging currentin the potential region where adsorption on the electrode surface takes place and by its sudden increase when the substance desorbs. Record of the charging current thus presents waves denoting adsorption and desorption (Fig. 2). The behaviour of these waves was followed with solutions of pyridine in $0.1 \mathrm{M}-\mathrm{NaOH}$, of tetrabutylammonium sulphate in $0.1 \mathrm{M}-\mathrm{Na}_{2} \mathrm{SO}_{4}$ and of the switch obey equation (3): they are directly proportional to the frequency of commutation and do not depend on the mercury pressure. However, the capacity $C_{1}$ is here a function of $\Delta E_{0}$ specific for each substance, and cannot be substituted by the values of the integral capacity. Koutecky $\hat{y}^{3}$ has deduced in his theoretical treatment that the mean electrolytic current obtained with the switch for a reversible electrode process at high frequencies and long drop times is independent of the mercury pressure and proportional to the square root of the frequency of com-
mutation $f$. In the present paper the independence of the mercury pressure and a direct propormutation $f$. In the present paper the independence of the mercury pressure and a direct proporof frequency of commutation permits to distinguish between the two different currents. There appears a formal analogy in polarographic techniques: A linear dependence is obtained when plotting the diffusion current intensity $a$ ) in ordinary polarography against the square root of the height of the mercury reservoir, $b$ ) in polarography with Kalousek's switch against the square root of the frequency of commutation and $c$ ) in oscillographic polarography with applied voltage ${ }^{7}$ ares

\section{References}

1. Kalousek M.: This Journal 13, 105 (1948)

2. Kalousek M., Rálek M.: This Journal 19, 1099 (1954); Chem. listy 48, 808 (1954).

4. Rálek M., Novák L.: This Journal 21, 248 (1956); Chem. listy 49, 557 (1955).

6. Frate

6. Frumkin A. N., Bagockij V. S., Iofa Z. A., Kabanov B. M.: Kinetika elektrodnych processov, p. 17. Izd. Moscov. univ., Moscow 1952.

7. Loveland J. W., Elving P. J.: Chem. Revs 51,67 (1952).
8. Matsuda H.: Z. Elektrochem. 62 , 977 (1958). Translated by the Auther.

\section{Резюме}

М. Гейровский: Зарлдный ток в полярограбии с прерывисто изменяюоиимся потенчиалом. При полярографии с прерывисто изменяющимся потенциалом при помощи переключател

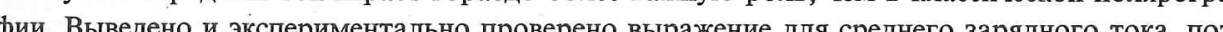
воляющее различать его от срепнего этектротитичестого тоге. 


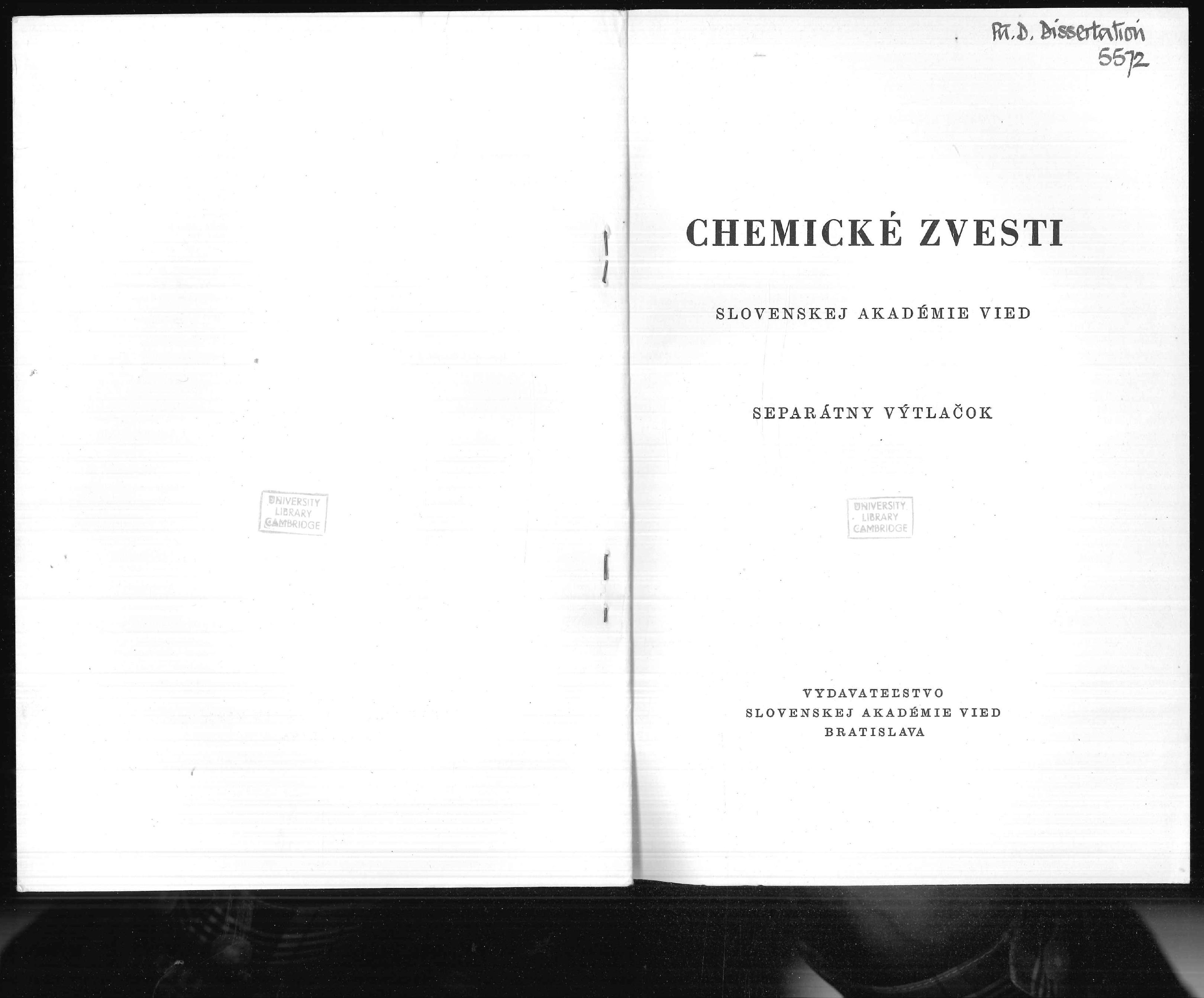


THEORY OF THE OSCULTOGRAPHIC POLAROGRAPHY WITH A. C. CURRENT

$$
\text { KAREL MICKA }
$$

Polarographic Institute, Crechosloval Academy of Sciences, Praha

Summary

The theory of the oscillographic polarography starts from the general integral equation The theory or the oscillographic polarogcury electrode during the polarization by means describing reversible processes at the murse. The solution of this equation can be carried out rigorously for the sineshaped. a. c. current in three limiting cases: 1 . the specific charge of the electrode is negligible, 2. the faradayic current is negligible, 3. the changes of the electrode potential are small. From the three limiting solutions the approximate equation describing the true state of the electrode during the polarization by means of the a. e. current can be derived. From this equation follow all the $=f(t), \mathrm{d} E / \mathrm{d} t=\mathrm{f}^{\prime}(t)$ and $\mathrm{d} E / \mathrm{d} t=\mathrm{f}_{1}(E)$ in agreement with the experiments. The potential of the peak of the incision al the denth of the incision (equal to the ratio between the of the depolarizer. The relative dept of curve without the depolarizer) is decreased slowly with increasing frequency of the a. c. current; with increasing temperature it is either slightly increased or remains unchanged. The capacity effects are defined like all changes of the shape of the curve $d E \mid d t=\mathrm{f}_{1}(E)$ caused by the change of the differential

capacity of mercury.
From the theory it follows how these effects can be distinguished from the incisions
. caused by the depolarizer. Further the significance or she d. componsation of the losses is elucidated which, accors at the electrode. In the ideal case when these losses do not of the it is fully sufficient to polarize the mercury electrode by the a. c. current without the d. c. component to obtain a rightly developed curve $d E \mid d t=f_{1}(E)$ on the screen of the polaroscope. The losses of the reduction products are caused by the institity the amalgams, by the vibrations of the mercury electrode or als by the inde potential to shift towards the more positive value

\section{LITERATURA}

1. Micka K., Collection 24, 3708 (1959); Z. physik. Chem. 206, 345 (1957). - 2. Hey.

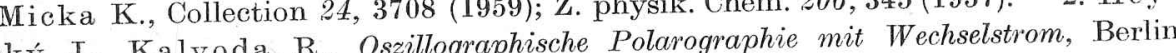
1960 .

Adresa autora:

. uistav ČSAV. 
ARTEFAKTY V OSCILOGRAFICKÉ POLAROGRAFII MICHAEL HEYROVSKY

Polarografický ústav Československé akademie věd v Praze

Je diskutována podstata a vznik tzv. artefaktů pozorovaných př̌i polarisaci Tupozoněno na rủzné typy artefaktů.

V oscilografické polarografii se setkáváme často s výsledky, které nelze vysvětlit prostým srovnáním s daty známými z klasické polarografie. Př́ičin tkví v rozdílném způsobu polarisace kapkové elektrody u obou metod.

Je tu jednak rozdíl $\mathbf{v}$ nabíjecích proudech. Střední nabíjecí proud v klasicke polarografii, řádu $10^{-7} \mathrm{~A}$, je obvykle zanedbatelný proti elektrolytickému. Naproti tomu v oscilografické polarografii vnuceným stř́davým proudem je nabijecí proud stejného řádu s elektrolytickým, a proto každá změna diferenciální kapacity, at již způsobená přítomností povrchově aktivní látky nebo jen změnou základního elektrolytu v roztoku, se zřetelně projeví na křivkách. Tyto změny jsou souhrnně označovány jako kapacitní efekty. Kapacitní efekt působené adsorpcí jsou patrné v klasické polarografii jen př̌i nejvyšších citlizứsobené adsortech nebo za poutí tryskavé elektrody.

Druhý bod, v němž se obě metody liší, je rozdílný rozsah potenciálové Druhý bod, v aměny na jedné kapce. $V$ polnoxín konstantnim potencialu (maxich difusní vrstva kolem elektrody je tvorena pouze depolanisátom a zplodinou jeho elektrodové reakce vznikajici prí daném potenciálu. S odkápnt ún odnese kapka zplodiny reakce $\mathrm{s}$ sebou a na novém povrchu probihá celý dèj opêt podle vloženého potenciálu, bez ohledu na déje, jež probêhly na predchozich kapkách. (Toto platí zcela presně u vodorovné kapiláry, kde nenastává prenos koncentrační polarisace.) V oscilografické polarografil naproti tomu se bèhem růstu jedné kapky změní potenciál ve velkém rozsahu — obyčejně kolem $2 \mathrm{~V}$; při stř́davé polarisaci s frekvencí $50 \mathrm{c} / \mathrm{s}$ se tato změna od 0 do $2 \mathrm{~V}$ a zpět opakuje asi 200 krát na jediném povrchu. Produkty reakce, která proběhla př̀ určitém potenciálu, zůstávají v difusní vrstrě i při další polarisaci a mohou se bud' samy účastnit jiné elektrodové reakce, nebo se chemicky přeměnit novou látku elektrodově aktivní.

Takové látky které nejsou obsaženy v původním systému roztok-elektroTa re vên její polarisace, nazýváme obecně a, ale artefakty [1] (do a povahu têchto látok usuzuje vych potenciálú na rúzných faltorech. Pring se projeri nèkteré z nich prì použití Kalouskova prepinacé nebo stálé visicí kapky, jejich pûsobeni je však
zcela typické pro oscilopolarografické metody.
V některých př́padech, zejména u organických depolarisátorů, vzniká na elektrodé tak velký počet artefaktú, że se oscilopolarografické vyssledky stávaji nepřehlednýn. Napríklad alkalický roztok nitrobenzenu [2], dávající jednu polarografickou redukě

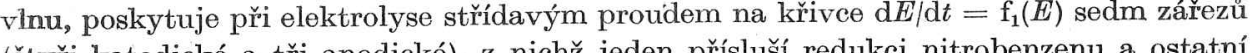
ingńm artefaktựm (oscilogram 1).

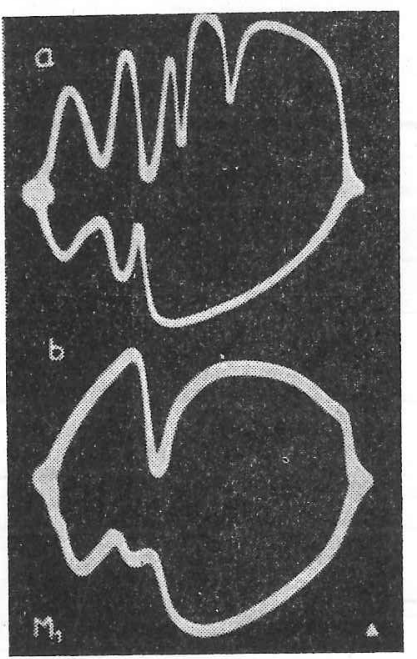

Oseilogram 1. Oscilopolarografické krivky $d E / d t=\mathrm{f}_{1}(E) 10^{-3} \mathrm{M}$ itto a) na kapkové, b) na tryskavé elektrodě.

Podle způsobu, jakým artefakty na elektrodě vznikly, můžeme rozeznávat artefakty elektrochemické a chemické. Elektrochemické, lkterých je vêtšina, jsou prýmé produkty redukci nitrobenzenu v alkalickém prostředí vznikají na kapee nitrosobenzen a fenylhydroxylamin ' [3] jako elektrolytické artefakty reagujićí spolu za tvorby chemického artefaktu, azoxybenzenu, který se dále redukuje ireversibilně na azobenzen.

Jakýmsi přechodem mezi elektrochemickými a chemickými artefakty jsou sloučeniny se rtutí, které vznikají na elektrodě reakcí složek roztoku nebo artefaktů s ionty rtuti vysilanymiz z elektrody prí positivnich potenciâlech. $Z$ texchto sloucenin se pu negativnejsich potenciálech redukuje rtut. Na polarogahy sloučenin se rtutí: príi potenciálech, pripadech pozorovat jen anodické vlny tviny slourchu kapek již nejsou. Sem patř̌i předevš́m ́účinky komplexotvorných látek, jako kyanidových iontů [4] (oscilogram 2), komplexonu aj., ale také acetylenu [5] a některých ketonú $\mathrm{v}$ alkalickém prostředí [6], kde dochází k tvorbĕ organortutných sloučenin.

A edukuji, nebo jen mèni kapacitu elektrody bez prenome olek pripadu je elektrodová reakce artefaktu spojená s adsorpci.

 
zíme ze srovnání s klasickou polarografí: zárezy na oscilopolarografických derivačních krịivkách, které není možno podle potenciálu přiřadit polarografickým vlnám, přísluš bud kapacitním efelktủm, nebo artefaktủm. Kapacitní efekty zpưsobené povrchove aktivnimi látkami z roztoku lze snadno urǒit srovnáním s krřivkami cistého zakladn ho elektrolytu, nejlépe pomocí metody srovnávacích titraci
derivační kríiva vlivem snižené kapacity elektrody zvýšena.

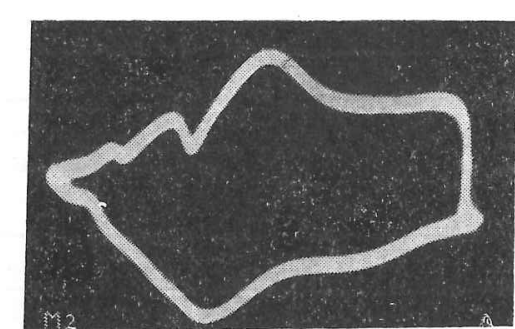

Oscilogram 2. Oscilopolarografická ǩ̌ivka $\mathrm{d} E / \mathrm{d} t=\mathrm{f}_{1}(E) 5 \cdot 10^{-4} \mathrm{M}-\mathrm{KCN}$ v 1 м м acetátovén

Při srovnávání oscilopolarografických a polarografických výsledkủ se setkáme také s př́pady, kdy polarografické vlně neodpovídá žádný zấřez na oscilopolarografické lřrivce. Dochází k tomu tehdy, když produkt elektrodového děje zůstává u povrchu elektrody a brání vlastní reakci. Takový je prípad iontủ hliníku, kde hydroxyd hlinitý jako zplo-
dina reakce zủstává adsorbován na kapce a brzdí dalš́ redulkci [8]. Když zaznamenáváme jina reakce, zủstává adsorbován na kapee a brzdí dalšsí redulkci [8]. Když zaznamenáváme zářez, který je na druhé menši a na páte až šesté zmizí úplnĕ.

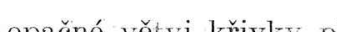

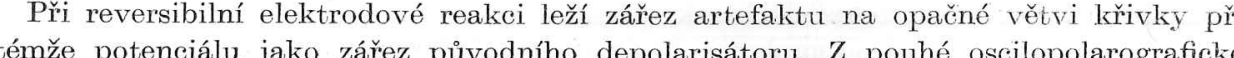
křivivy však nemůžeme říci, je-li depolarisátor v roztoku v oxydované formě a artefak t na elektrodě v redukované anebo obráceně, nebo kolik procent depolarisátoru je v roztoku v oxydované a kolik v redukované formě. 'V tomto směru jsme odkázáni na klasickou

Leežili dva zářezy na křivce $\mathrm{d} E / \mathrm{d} t=\mathrm{f}_{1}(E)$ proti sobě při témže potenciálu, munže též jít o dva různé, nezávisislé procesy, zvláště jsou-li zářezy rozdílné svým vzhledem. tak, ̌̌e potenciál nedośáhne hu stejnosměrné složky proudu: zpolarisujeme-li elektrodu netvoří se dále artefakt a zářez př́íslušejićí artefaktu zmizí. Nedosáhne-li elektroda potenciálu redukce zinku, zmizí zá̌̌ez oxydace zinkové amalgámy. Z toho vyplývá, že hloubka zářezu artefaktu je citlivá na nastavení stejnosměrné složky. To je zejména patrno nastává-li primární dèj prì jednom z krajnich potencialú. Trojmocny chrom, např́ḱklar [9], tvờ $\checkmark$ louhhu chromitan, jenž se ieversibilnè oxyduje na chroman prì potenciálech reakce ani neprojeví. (Na oscilogramu 3 je uvedena lř̌ivka $i=f_{2}(E)$ pořízená $s$ trojúhel. níkovým stř́ídavým napětím frekvense $50 \mathrm{c} / \mathrm{s}$.) Chroman se palk v katodické fáze následují cího cyklu redulkuje zpět na chromitan. Není-li elektroda polarisována k dostatečně po. sitivním. potenciálưm (tj. nesvítí-li jasnĕ levý okrajový bod křivky $\mathrm{d} E / \mathrm{d} t=\mathrm{f}_{1}(E)$ na obrazovce), katodicky zarez chromanu se neobjevi. Je tedy zrejmé, ze pro ziskáni repro- vhodnou volbou strúídavé a stejnosměrné složky proudu polarisovat elektrodu w maximálním rozsahu potenciálů - tj. tak, aby okrajové body lrřivky zůstaly po celou dobu kapjky na mezných potenciálech rozpouštění rtuti a vylučování kationtu základního elektrolytu

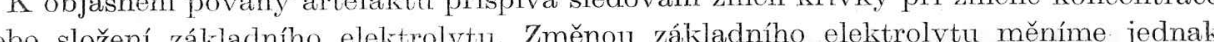
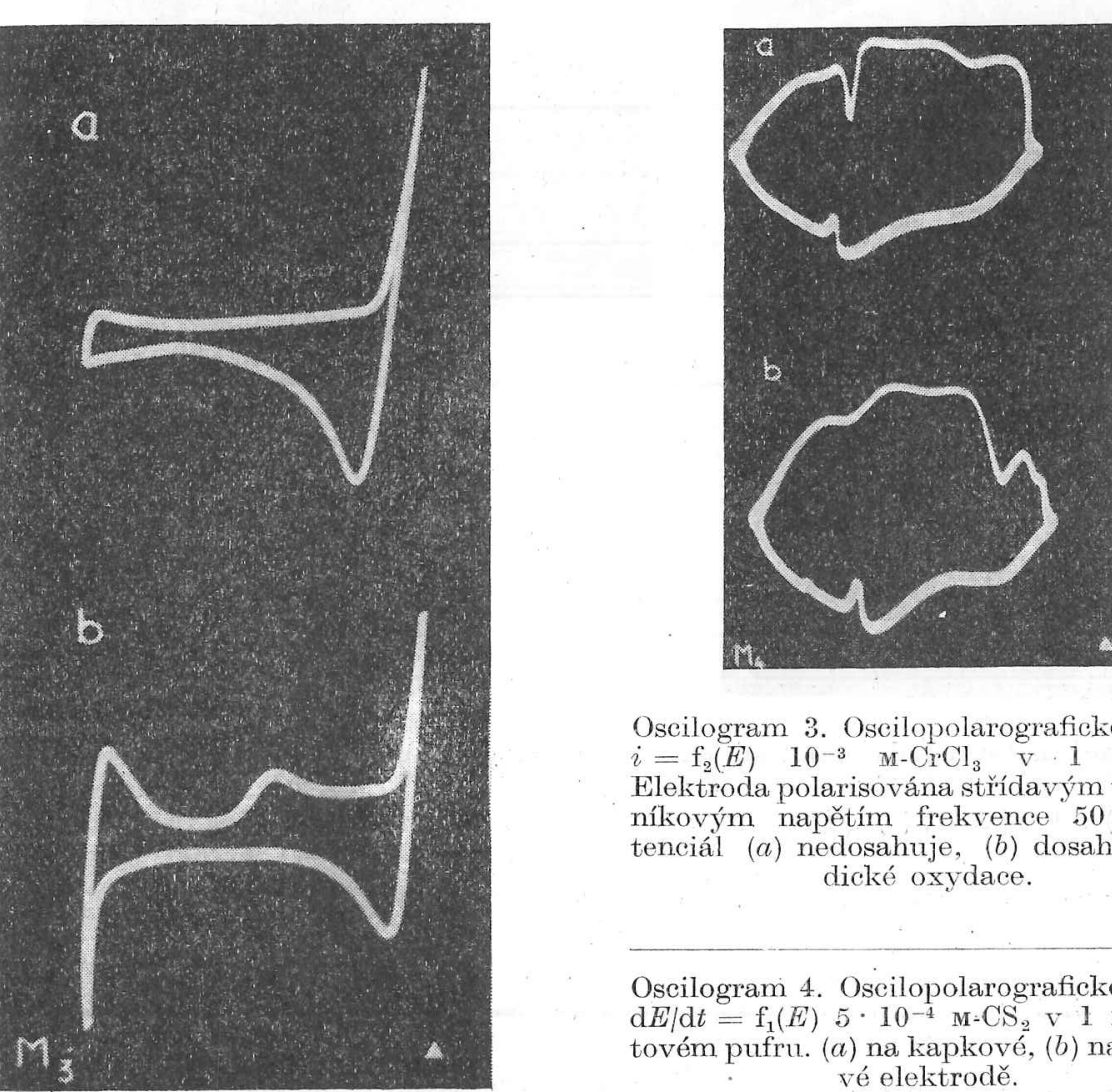

Oscilogram 3. Oscilopolarografické křrivky
$=\mathrm{f}_{2}(E) \quad 10^{-3} \cdot \mathrm{M}-\mathrm{CrCl} \mathrm{I}_{3} \mathrm{v} \cdot 1 \mathrm{M}-\mathrm{KOH}$ Slektroda polarisovana strúvidavým trojúhe

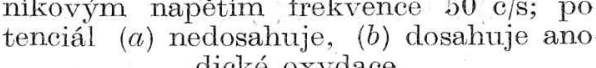

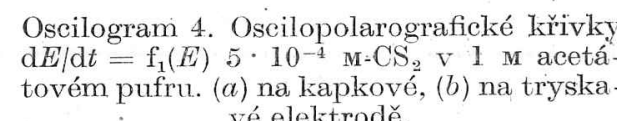

látku, která se mủže s depolarisátorem podilet na tvorbě artefaktu, jednak měnime po tenciálové meze, jichž mưže elektroda př̌i polarisaci dosáhnout; omezováním potenciálu prìidavkem rüznych elektrolytu v nadbytku mużeme urcit potenciá, prí kterém ke vzniku

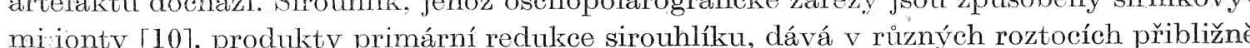
stejný efelkt pokud potenciál elektrody dosahuje dostatečně negativních hodnot. Př̀ nadbytku zinečnatých iontủ v roztoku zmizí zářezy sirouhlíku, protože nemůže dojit k primární redulkci. sirouhlíku na sirník, která nastává při - $1,25 \mathrm{~V}$, kdyŭ zinečnaté ionty se redukuji prri $-1,05 \mathrm{~V}$ (v octanovém pufru, SKE) (oscilogram 4). S acetylenem naproti tomu dostaneme zarezz redukce sloučeniny se rtuti jen v koncentrovaných louzich [5] a ionty hlinité se projevuji složitým artefaktem výhradnế za pritomnosti lithia

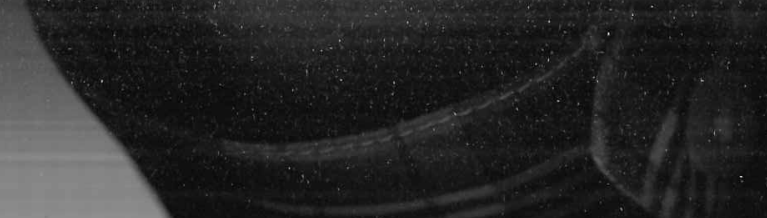


v chování látky na elektrodĕ. Aceton dává v alkalickém roztoku artefakt - sloučenin

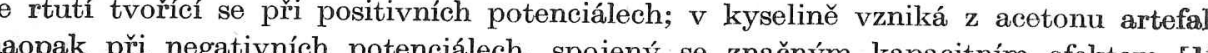
(oscilogram 5).
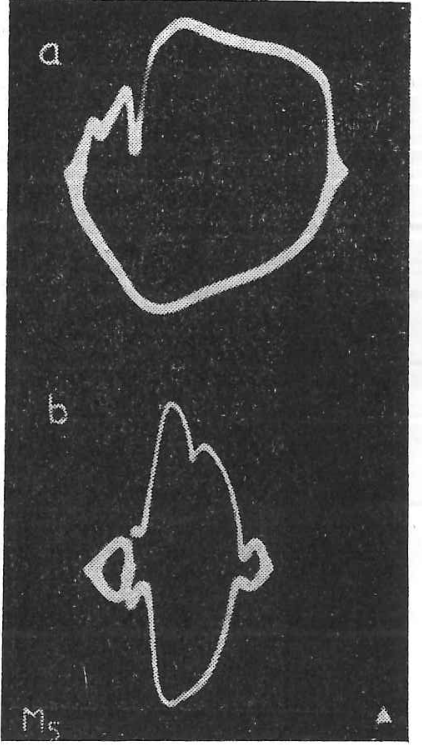

Oscilogram 5. Oscilopolarografické křivl $(a)$ v $1 \mathrm{M}-\mathrm{KOH},(b)$ v $1 \mathrm{M}-\mathrm{HCl}$.

Je-li v roztoku př́tomen kyslik, dochází na elektrodĕ $\mathrm{k}$ jeho redukci, $\mathrm{i}$ kdy̌̆ to nent z křivel patrno, a zplodiny této redukce - peroxyd vodíku a hydroxylové ionty - moho $\mathrm{s}$ depolarisátorem tvoriti rủzné artefakty. To pozorujeme napriklad s ionty železnatými, manganatými [4], kobaltnatyymi a s kadmiem a olovem v neutrálních základních elektro-

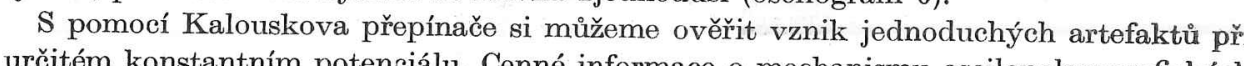
efektủ podávají již zmíněné křivky, zaznamenané při jednotlivých polarolarografafickýc metodou podle R. Kalvody a J. Mackủ [13]. Tyto křivky nám ukazuji, že nĕkteré artefakty se objevuji teprve po prvním cyklu a s opalkováním polarisace se hromadí n elektrodĕ, jak je tomu naprríklad u hliníku za prìtomnosti lithia [14]. Jiné artefakty vzniknou v prvnim cyklu a opakovanou polarisaci jejich efekt mizi - tento prípad pozorujem

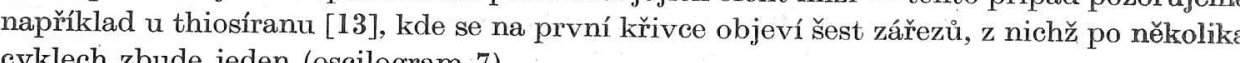

(bnova povrchu elektrody tuktrodových procesủ je tryskavá elektroda. Ryehlá hromadění reakčních zplodin a reakce mezểnout jen nejjednodušším reakcím, odpada proto zpravidla jednodušsi než křivky téhoǔ roztoku zaznamenané s kapkovou elektrodou (srov. oscilogram 1). $Z$ artefakttu se na tryskavé elektrodě mohou uplatnit jen jednoduché

artefakty elektrochemické a sloučeniny se rtutí. Zdviháním rezervoáru rtuti zvyšujeme dĕ; jejich zá̌rezy se následkem toho zmenšují a peř́padnĕ úplnĕ vymizí (oscilogram

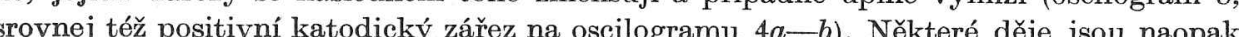
lépe patrny s tryskavou elektrodou, kde se nemohou dostatečně uplatnit brzdivé úćinky

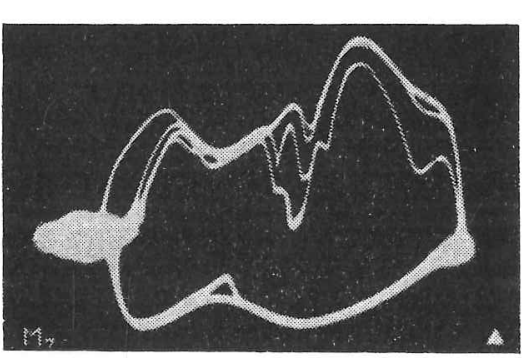

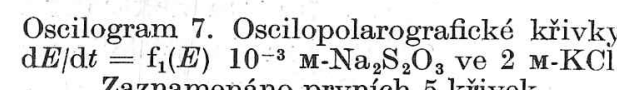
Zaznamenáno prrnich 5 k krivelk.

Oscilogram 8. Oscilopolarografické křivky
$\mathrm{d} E / \mathrm{d} t=\mathrm{f}_{1}(E)$ acetylenu v $5 \mathrm{~m}-\mathrm{NaOH}$. (a) na kapkové, (b) na tryskavé elektrodĕ.
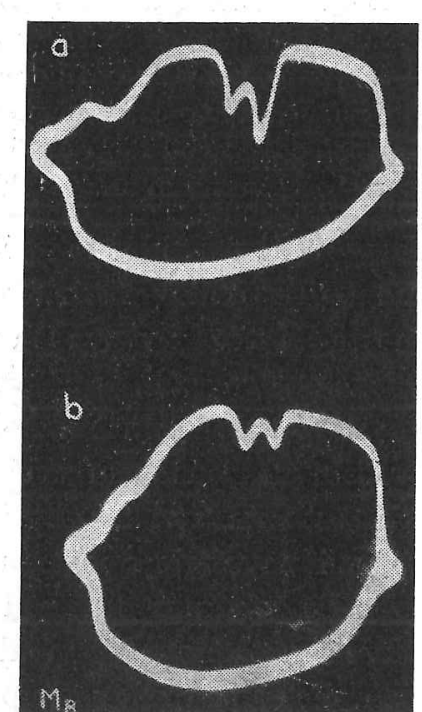

reakčních produktů. Například zárez redukce sirouhlíku, vedle nápadného zářezu artefaktu — sirníkových iontủ — sotva patrný na kapkové elektrodě, na tryskavé elektrodĕ se projeví velmi výrazně (oscilogram 4).

Jsou-li artefakty dostatečně stálé, je možno $\mathrm{k}$ jejich sledování použí stálou rtutovou (15) [15]), a registrovat křivky v klasickém polarografickém zapojení. Touto cestou lze

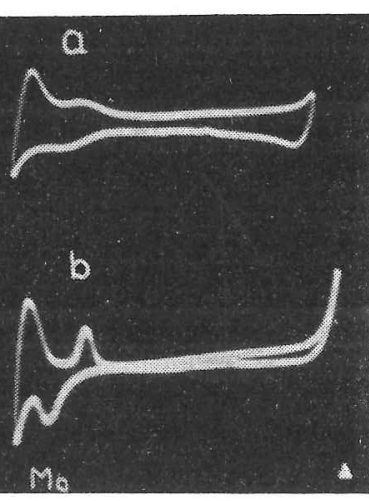

Oscilogram 9. Oscilopolarografické křivky $\left.i=\mathrm{f}_{2}(E)\right) 1 \mathrm{M}-\mathrm{MgCl}_{2}$. Elelektroda polarisována

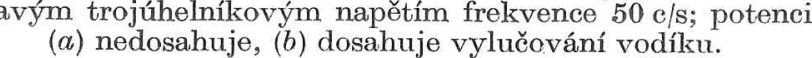


napríklad zachytit též artefakty vznikajicí v hořečnatých solích jalko základních elektrolytech, zpolanistajeme-li elektrodu $k$ dostatečně negativnim potenciálùm, kde při reduk vrehu elektrody vytvoří chemický artefakt — sraženinu hydroxydu hořečn tom na pọ

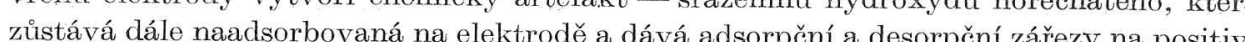
ní straně od elekektrokapilárního maxima. Zvláššte silný je tento efekt v roztocích nitrátio kde redukcí nitrátových iontů vzniká velké množství iontů $\mathrm{OH}^{-}$. Za přítomnosti iontê amonných, kdy se hydroxyd hořečnatý nesráží, nedochází k tvorbĕ artefaktu a zárěezy se neobjeví. Jde zde o častý príipad elektrodové reakce kombinované s chemickou reakc

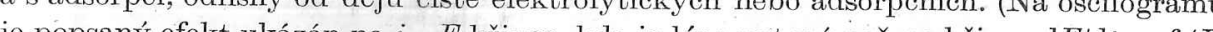
je popsaný efekt vltáźch

Jak vyplývá z uve lených přikladů, artefakty hrají $\mathrm{v}$ mechanismech elektrodových dějů v oscilografické polarografii prvořadou úlohu. Jsou to látky měnící vlastnosti elektrody $\mathbf{v}$ pråběhu elektrolysy; jejich působení nespadá $\mathbf{v}$ úvahu v klasické polarografii, jejiž jednou z předností je, že povrch elektrody zůstává stále čerstvý. Oscilografická polarografie všık přinesla možnost sledovat reprodukovatelným způsobem zmy̌ny nastávající na elektrodě během elektrolysy a využít ty to zmø̌ny $i$ k analytickým účllùm. V tom to směru na oscilografickou a vyž̌t ty z a polarografi Podrobnè grafických metodách, by mohl poməsi i při studiu procesů na pevných elektrodách, jichž je rtutová kapková elektroda ideálním modelem.

АРТЕФАКТЫ В ОСЦИЛЛОГРАФИЧЕСКОЙ ПОЛЯРОГРАФИИ МИХАЕЛ ГЕЙРОВСКИ

Полярографический институт Чехословацкой академии нау

$$
\text { в Праге }
$$$$
\text { Выводы }
$$

В осцилзограф̆ической полярографии называем артеф̆актом вещество, которое не содержит раствор, но возникает на электроде в ходе его поляризации и проявляется

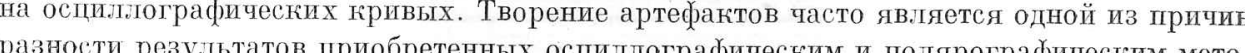
дами. Сравнением результатов приобретенных ослилтографическия и полирографоческим методами или с переключателем Калоуска при различных частотах, пзучением щервых кривых, сравненшем кривых приобретенных с капельным и струйчатым электродами и наблюодением взиянния постоянной слагаемой тока и состава фона на осциллотрафическую кривую, можно отличить, принадлежит-ли эффеект веществу присутному Болторе или артефанту.

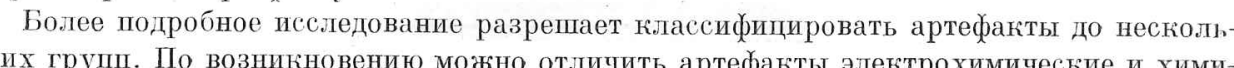

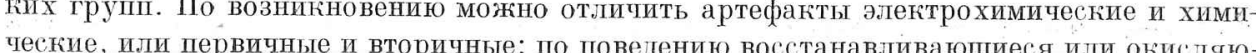
щиеся и артефакты атсорб̆шионныт,
ARTEFAKTE IN DER OSZILLOGRAPHISCHEN POLAROGRAPHIE MICHAEL HEYROVSKÝ

kischen Akademie der Wissensehaften in Praha

Zusammenfassung

Als Artefakte bezeichnen wir in der oszillographischen Polarographie jene Verbindungen, die in der untersuchten Lösung nicht anwesend sind, sondern die erst im Verlaufe der Polarisation der Elektrode an deren Oberfläche entstehen und Einschnitte an den oszillopolarographischen Kurven bieten. Die Bildung der Artefakte ist einer der Gründe der oft unterschiedichen Resultate der oszillographischen Methode von der klassischen
Polarographie. Durch den Vergleich der oszillographischen Resultate mit der klassischen Polarographie und dem Umschalter nach Kalousek bei verschiedenen Frequenzen, durch
Vergleich der Kurven, die mit der tropfenden und strömenden wurden, durch das Studium der „ersten“ Kurven und Verfolgen des Einflusses der Gleichstromkomponente und der Zusammensetzung der Grundlösung auf die oszillographische Kurve können wir unterscheiden, ob der Einschnitt der Verbindung die in der Lösung anwesend ist oder einem Artefakt gehört.

Ein ausführliches Studium ermöglicht es, die Artefakte in mehrere Gruppen einzuteilen. Dem Ursprung nach kônnen wir elektrochemische und chemische, event. primare und sekundare Artefakte unterscheiden; nach dem Verhalten können wir die Artefakte

ARTEFACTS IN OSCILLOGRAPHIC POLAROGRAPHY MICHAEL HEYROVSKÝ

Polarographic Institute, Czechoslovak Academy of Sciences, Prah

$$
\text { Summary }
$$

Substances which are not present in the solution, but which are formed at the electrode in the course of its polarization and cause changes of the oscillographic curves are called in oscillographic polarography artefacts. The formation of artefacts is one of the reasons of the frequent difference between the results of the oscillographic methods and those of the classical polarography. By comparing the oscillographic results with the classical polarsiaphy and with the commutator according to Kalousek using various frequencies, the streaming electrode and by following the curves obtained with the dropping and the composition of the supporting electrolyte on the oseillographic curve it ent and of stinguished, whether the effect is caused by a substance present in the solution or by an artefact.

A more detailed study enables us to classify the artefacts into several groups. According to their origin electrochemical and chemical, event. primary and secondary artefacts can be distinguished; according to the behaviour we know reducible, oxidizable and ad-
sorptive artefacts. 
LITERATURA.

1. Heyrovský J., Forejt J., Oscilografickć polarografie, Praha 1953, 97. - 2. Ibid. 105. - 3. Volke J., Chem. zvesti 14, 807 (1960). - - 4. Heyrovský J., Techn. práca 5 , Nepublikováno. - 7. Kalvoda R., Macků J., Chem. listy 48, 254 (1954): Collection 20, 257 (1955). - 8. Heyrovský M., Z. physik. Chem. (Sonderheft) 1958, 97. - 9. Heyrovský M., Nepublikováno. - 10. Heyrovský J., Forejt J., Oscilografickéc

polarografie, Praha 1953, 96.
11. Heyrovský J., Chem. listy 4\%, 1762 (1953); Collection 18, 749 (1953). — 12. Hey-

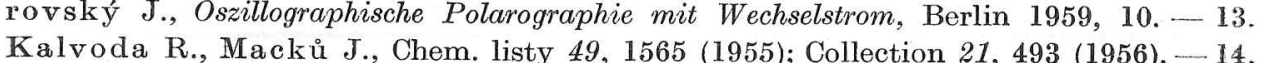

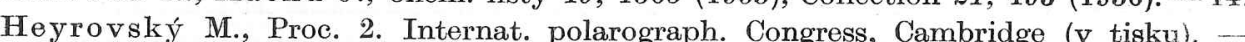
15. Vogel J., Kandidátská disertace, Polarografický ústav ČSAY Praha 1960. Adresa autora:

Prom. chemik Michael Heyrovský, Praha 1, Vlašská 9, Polarografický nistav ČSAF. 


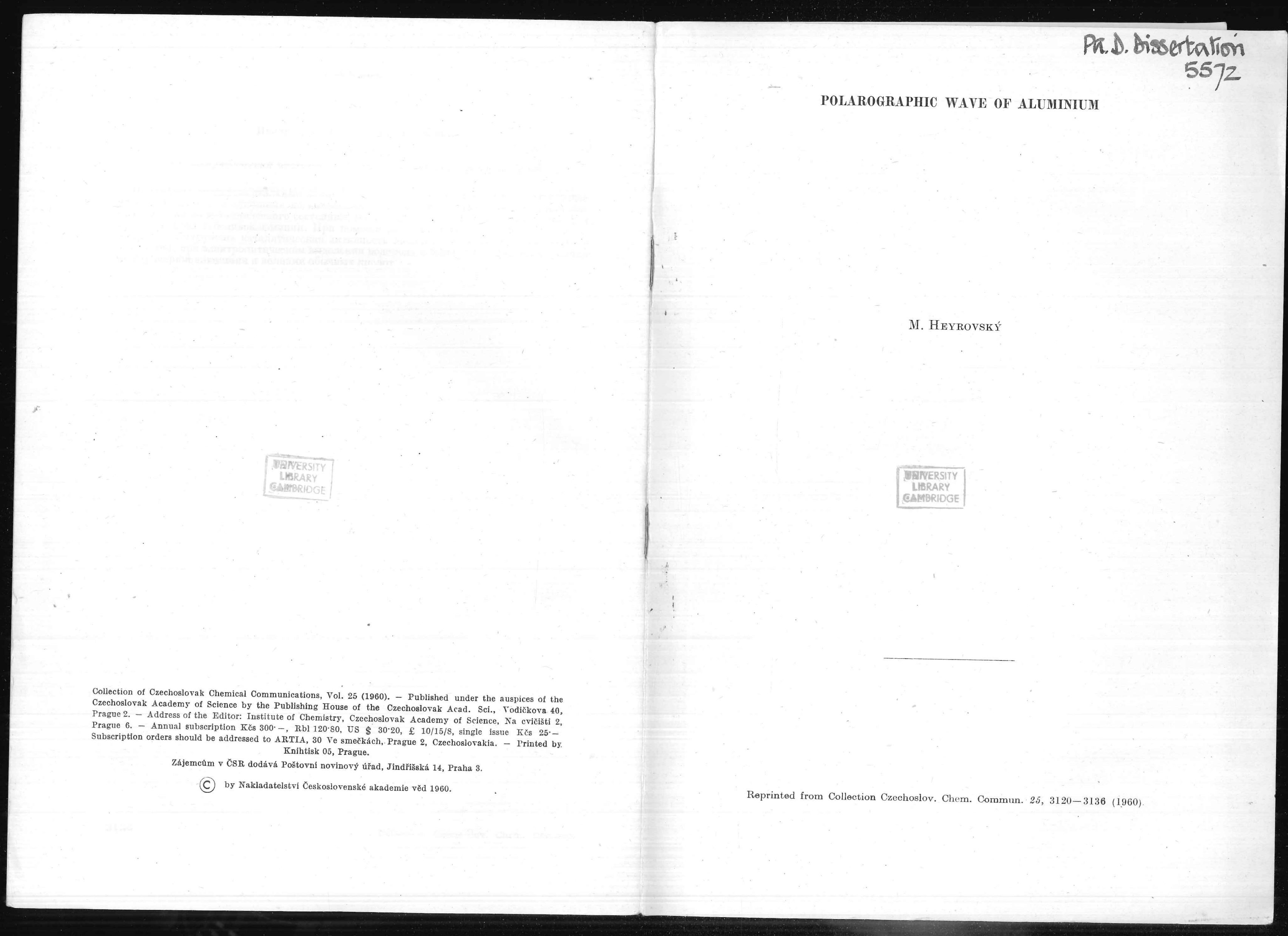


POLAROgRAPHIC WAVE OF ALUMINIUM

M. HeYRovskÝ

Polarographic Institute, Czechositovak Academy of Science, Prague Received February 8th, 1960

To Academician J. Heyrovsky on his Yoth birthday.

Experimental data are given to prove that the polarographic wave of
aluminium ions on the dropping electrode does not consist in reduction of
cation to metellie the are reduced. By various polarographic technniques catalyticic activity of the
reaction product, the aluminium hydroxide, in electrolytic evolution of hydrogen is revealed and all differences between the aluminium wave and
the waves of ordinary acids are exphan

It is a known fact in technical electrochemistry that aluminium cannot be electrodeposited
from aqueus solutionst. The aqueous solutions of

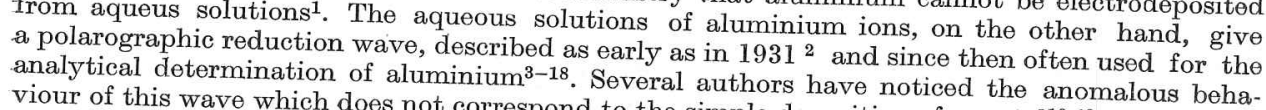

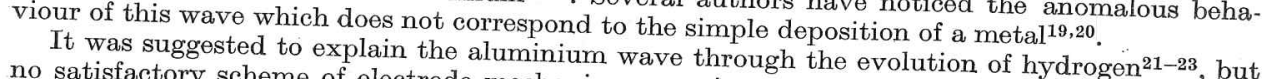
no satisfactory scheme of electrode mechanism was given. In papers published independently by two authors $24-27$ th to them the electrode reaction consists in rated aluminium ion in aqueous solutions. According aluminium complex, which is thus changed into non-reducible aluminium hydrom the hexaquonium wave. Later the experimental data, but it cannot explain all properties of the alumifor a better fitting explanation $n^{28}$, but neither this was sat resfactoction of aluminium into account

The experiments described in the present paper prove that the polarographic complex proceeding under the catalytic actir Ainium hydroxide, adsorbed at the electrode surface Aluminium hydroxide which is adsorbed at the electrode in the electrode pave and the sim the aluminium similarity of the polarogve of proton reduction from an ordinary acid. The other cations shows that the conaviour of aluminium ion with that of some are of a more general validity.

\section{Experimental}

Chemicals and Apparatu

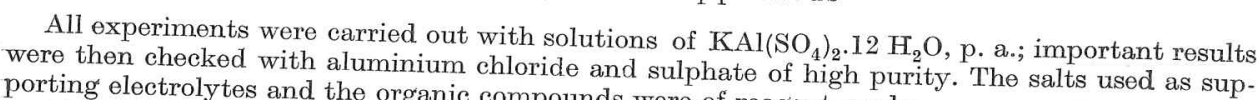
Aluminium amalgam was prepared according to the reagent grade. 列 3120
Polarographic Wave of Aluminium

which the amalgam was prepared served, after cooling, directly as a reservoir for the dropping (a) time was consequently short, about $0.2 \mathrm{~s}$. electrode. All the solutions were deprived of oxygen by passing pure nitrogen through the cell. The surface of the dropping mercury electrode was observed by means of a binocular microscope
through a plane round window in the wall of the cell according to Serák ated calomel electrode.

For streaming electrode the arrangement described by Kủt ${ }^{31}$ was applied. In these experiments correction on the potential drop i. $\mathrm{R}$ was made. The resistance of the whole polarizing circuit and of the cell was found to be $400 \Omega$

(1) fication.
Polarographic curves were registered using $V 301$ and LP 55 polarographs; oscillographic curves were followed with the $\mathrm{P} 576$ polaroscope Križzik and the voltage impulse polarographi

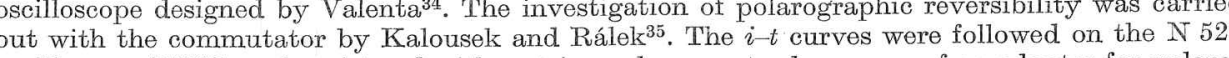
oscilloscope Kř̌zík and registered with a string gal
graphic $i-t$ curves devised by Nömec and Smoler ${ }^{36}$.

To keep the temperature constant a simple thermostat was used; the restst of at varying temperature are correceted for the temperature dependence of the potential of saturated

Logarithmic analysis of $i-t$ curves was done after the correction for the charging current.
The A. C. polarographic curves were drawn point by point with the use of a simple circuit consisting of the $\mathrm{V} 301$ polarograph, $R O$ alternating voltage For plotting electrocapillary curves the drop-time of ten drops was measured at every $50 \mathrm{mV}$
of the voltage applied to the dropping mercury electrode. Mean values of three independent

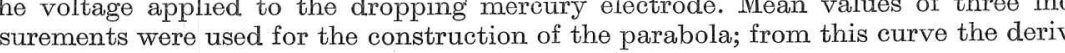
obtained by graphical method. $\mathrm{pH}$-values were measured using a Phillips GMT pH-meter w

Results

Unbuffered aqueous solutions of aluminium salts, slightly acidic because of drolysis, give a polarographic reduction wave the shape and position of which depend remarkably on the composition of the solution (Fig. 1). In $0 \cdot 1$ r solutions of salts of alkali metals or alkaline earth metals the waves are very

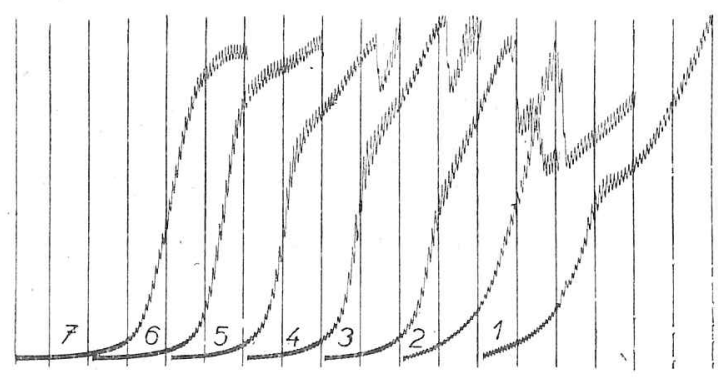

Fic 1

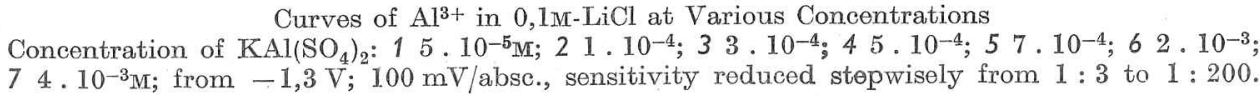




$$
\text { Heyrovsk'y. }
$$

similar; for investigation of the electrode process lithium or tetramethylammonium salts are most suitable as supporting electrolytes.

a half-wave potential at $-1.58 \mathrm{~V}$ is purely diffusion-coum salt the wave with. analysis gives two straight linear parts the slopes of which are $132 \mathrm{mV}$ (at more positive potentials) and $84 \mathrm{mV}$, respectively. The wave height corresponds according to the llkovic equation to a 3-electron reduction. With increasing temperature between 10 and 60 e the limiting current increases by $1.2 \%$ per degree and the half-wave potential shifts to positive values by From the coneente.

there appears a entration of about $6 \cdot 10^{-5} \mathrm{M}$ at the rising part of the curve more negative potentials. The current at maximum is a linear function of the square root of the height of mercury reservoir the dependence showing a kinetic: component of the current.

on $i-t$ curves obtained at potentials at which the polarographic curve exceeds the height of the limiting difrusion current there appears at first a slight sharp cuts the number afsorption process. The undulation changes into summit of the maximum. The shape of these $i t$ curres is not exactly reprodueible; between the first and the following drops (Fig. 2) there is no essential difference. After the fall of the maximum the shape of $i-t$ curves indicates adsorption taking place at the beginning of the drop-time. In the potential rango of the maximum one observes a mild streaming of the solution in smal whirls round the surface of the electrode, without any uniform direction,

This maximum is suppressed by gelatine or by a small concentration of at the concentration of about $1.7,10^{-4}, \mathrm{y}^{-} \mathbf{1}^{3+}$, when current peak is reached attains almost twice the value of the limiting current. At hicher concentrations the ratio of maximum to the limiting current decreases, but the occurrence of the maximum remains characteristic for the aluminium wave.

The maximum is highly sensitive to the presence of hydrions or proton donors in the solution (Fig. 3). Hydrogen ions from stronger acids, reduced at potentials more positive than is the maximum, cause an increase of the

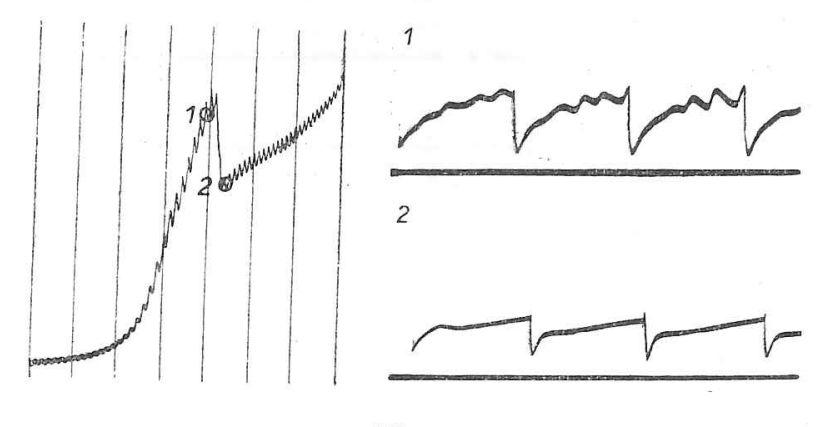

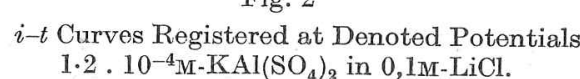

\section{Polarographic Wave of Aluminium}

maximum by more than $100 \%$ at a concentration 5times higher than that of aluminium ions. The increase of maximum with addition of strong acid is not linear - it reaches a limit which is practically obtained at a tenfold excess of hydrions over aluminium ions. Weak acids giving the hydrogen wave at potentials more negative or giving no wave at all (e. g. boric acid, phenol or 10 to 50 times the whole wave of aluminium ions disappears in a drawn-out eurve due to the reduction of hydregen ions $($ c. 23 ).

at the foot of the wave a steep increase of of aluminium ions there appears concentrations extends to the whole ascendirg part of the curve. From the dependence on the mercury pressure it follows that this increase is of an autoincreases (Fig. 4). The autocatalytic nature is clearly demonstrated by the $i-t$

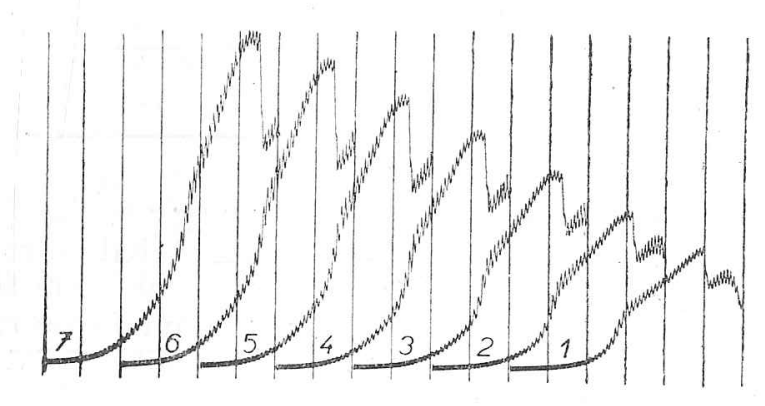

Fig. 3

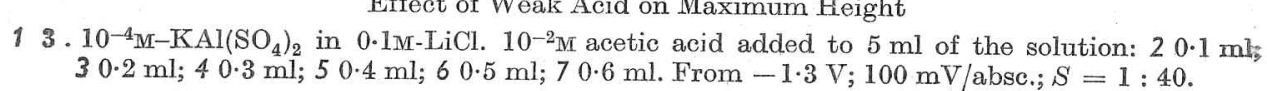

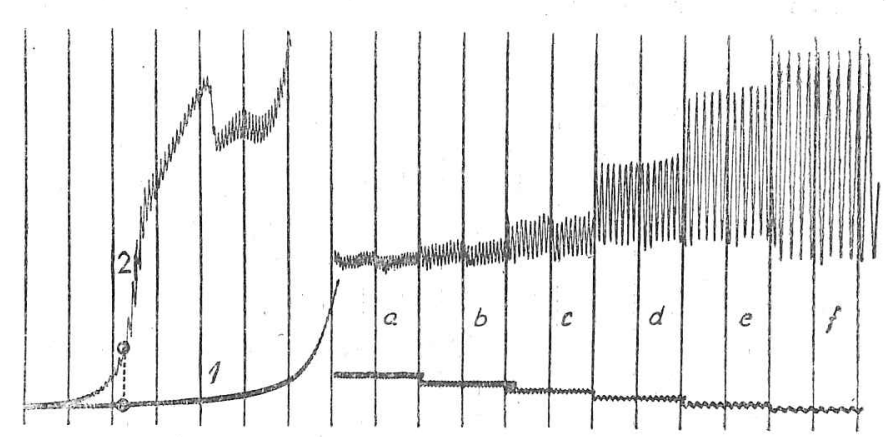

Fig. 4

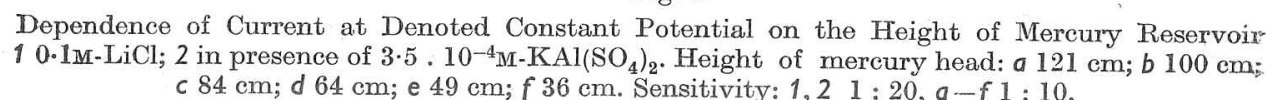
$84 \mathrm{~cm} ; \mathrm{d} 64 \mathrm{~cm}$; e $49 \mathrm{~cm} ; f 36 \mathrm{~cm}$. Sensitivity: 1, 2 1:20, a-f $1: 10$. 
Heyrovskly:

curves (Fig. 5); their shape corresponds to the equation $i=k . t^{a}$, where $a$ attains the value of $1 \cdot 25$. When the potential gets gradually more negative, and finally the shape of the curve results in the form of damped oscillations. In the region of potentials of the maximum (cf. Fig. 1 on polarographic curves the regular oscillations on $i-t$ curves change into irregular acute cuts, the number of which increases to chads tho hightost poit

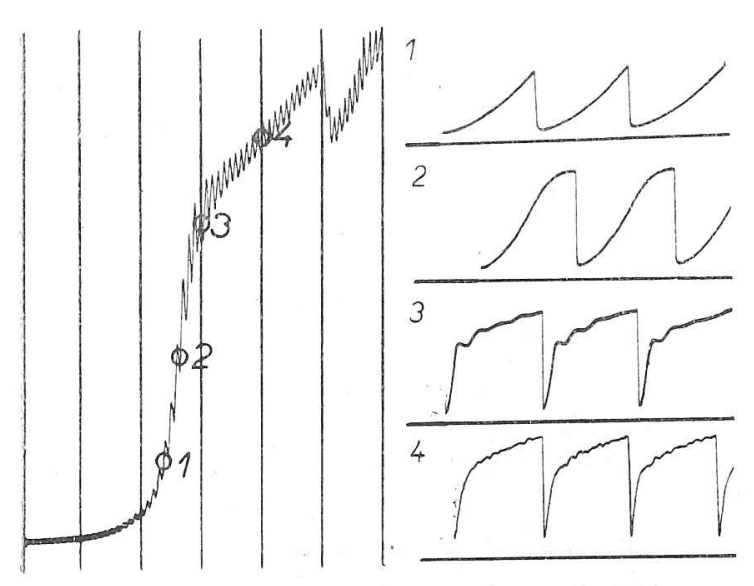

Fig. 5 there appears a second rounded aximum (cf. Fig. 1) of a cataly e nature which is evident from the dependence on the mercury pressure and from the $i-t$ cur es. If constant potential of he second maximum is app1ls after an interval of about 10 drops to the height of hree-electron reduction and then its value remains virtually constant, only with slight irre gular oseillations (Fig. 6). When using a horizontal capillary the egistered ourrent-voltage curmaximum a wave merging into the current of deposition of $\mathrm{Li}^{+}$ $-t$ Curves Registered at Denoted Potentials
$4.10^{-4} \mathrm{M}_{\mathrm{M}}-\mathrm{KAl}_{\mathrm{SO}} \mathrm{SO}_{2}$ in $0,1 \mathrm{M}-\mathrm{LiCl}$. ions.

Polarographic curves and sequences of $i-t$ curves closely similar to the curves due to aluminium
ins are obtained for berylliwm and seandiwm with the only difference that the wave for scandium is by about $50 \mathrm{mV}$ and the wave for beryllium by $140 \mathrm{mV}$ more negative (Fig. 7 .

Autocataly tic shape of $i-t$ curves changing into oscillations with increasing negative potential was observed also for lanthanum and some rare earth metals (tried with $\mathrm{Pr}$, Nd, Sm). Thoriu gives curves have the same structure of irregular oscillations of high frequency as with aluminium.

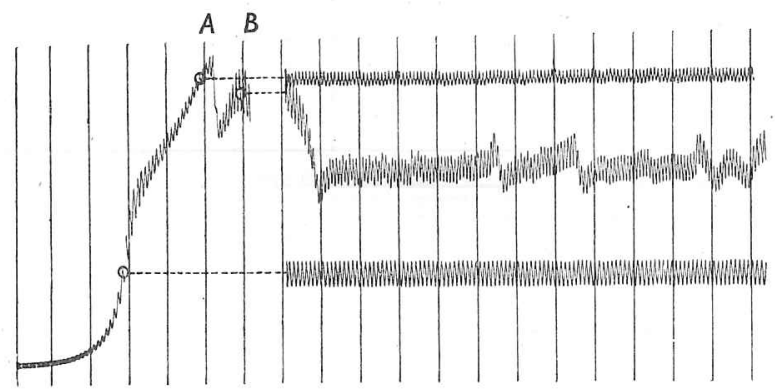

Fig. 6

Time Dependence of Current Registered at Denoted Constant Potentials
$\left.3 \cdot 8 \cdot 10^{-4} \mathrm{M}_{\mathrm{M}}-\mathrm{KAl}_{(\mathrm{SO}}\right)_{4}$ in $0 \cdot 1 \mathrm{M}-\mathrm{LiCl}$; distance of abscissae $31 \mathrm{~s}$.
Heyrovskíg:

In $10^{-3} \mathrm{M}$ solutions of aluminium salts in $0.1 \mathrm{~N}$ supporting electrolyte the wave of alluinim ions accompanied by evolution of small bubbles of gas on the eloctrode, as obsorved by means of a microscope At potents of the

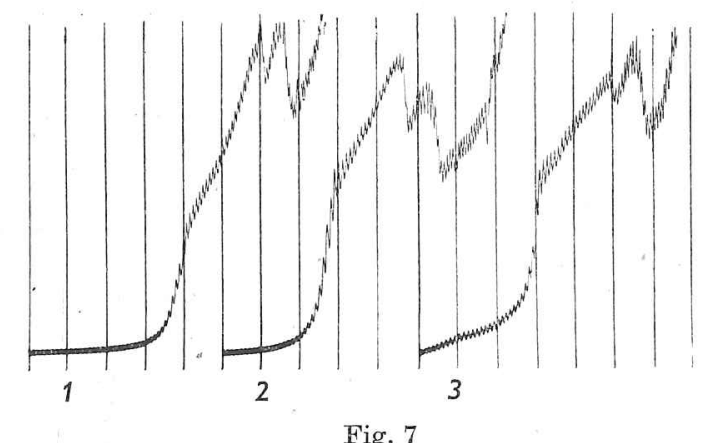
Polarographic Curves of $4.10-4 \mathrm{M}_{1} \quad 1 \mathrm{BeCl}_{2}, 2 \mathrm{AlCl}_{3} ; 3 \mathrm{SeCl}_{3}$ in $0 \cdot 1 \mathrm{M}-\mathrm{LiC}$
From $-1.3 \mathrm{~V} ; 120 \mathrm{mV} /$ absc., $S=1: 20$.

At more negative potential this movement becomes quicker, chaotic and jerky; on the surface there float small islets of a colourless crystalline substance which gradually get thicker and form a continuous white film. The intensity of the whirling motion of the surface becomes greatest at about $1 / 4$ of the total height of the wave; when the white film covers the electrode, the motion becomes slower again. The solution surrounding the electrode remains during the motion of the surface entirely quiet. When the potential approaches the

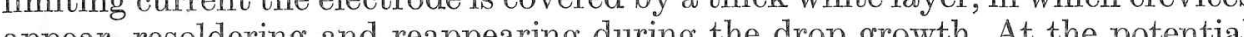
appear more. At potential of the second maximum the solution round the electrode becomes turbid and whirls slightly, whilst the electrode surface remains quiet. This whole process is accompanied by the formation of tiny bubbles of gar collecting at the orifice of the capillary. In presenco of a plex forming anions in the solution the white film disappears and the motion

$\begin{aligned} \text { Quite analogous effects may be obser- } & \\ \text { ved in solutions of beryllin } & \end{aligned}$

dium at potentials of their reduction wea-

ves. White moving film and evolution of
bubbles at the electrode surface appear

bubbles at the electrode surface appear
even with thorium and lanthanum; the

formed white layer does not appear so
thick and voluminous as with aluminium,

thick and voluminous

Fig. 8

Dependence of Half-wave Potential of the Aluminium Reduction Wave on Alu-

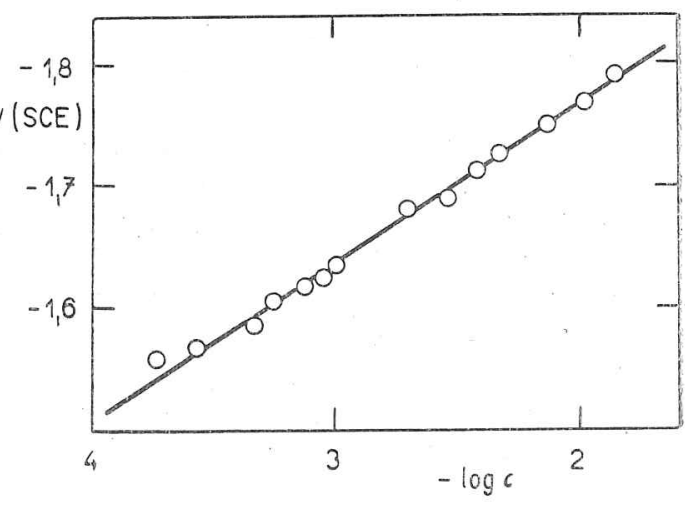

3125 
Heyrooskly:

With increasing concentration of aluminium ions the whole wave shifts tentials (Hig. 8), an analogous eflect has solution (Fig. 9).

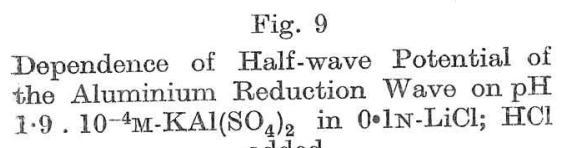

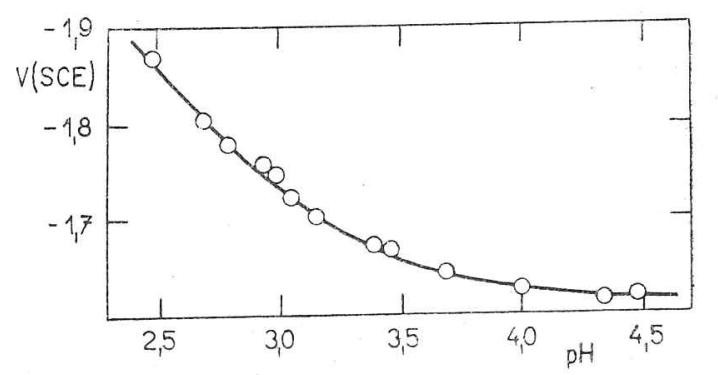

The temperature coefficient of the half-wave potential is $3.5 \mathrm{mV}$ per degree at $1.10^{-4} \mathrm{M}, 3.3 \mathrm{mV}$ per degree at $3.10^{-1} \mathrm{M}$ and $2.9 \mathrm{mV}$ per degree at 7.5 $.10^{-4} \mathrm{MI}-\mathrm{Al}^{3+}$. The temperature coefficient of the limiting current of the whole wave with the first maximum is constantly about $12 \%$ por dogre, the whe height of the first maxum $B$ has demperature coefficient about $4.4 \%$ per degree.

With increasing concentration the wave first becomes steep proximately straight line with a slope of $94 \mathrm{mV}$. The approximate values of the slopes obtained for various concentrations are as follows: $48 \mathrm{mV}$ for $2 \cdot 9 \cdot 10^{-4} \mathrm{M}-\mathrm{A} l^{3+} ; 45 \mathrm{mV}$ for $4 \cdot 3 \cdot 10^{-4} \mathrm{M}-\mathrm{Al}^{3+}, 42 \mathrm{mV}$ for $74.10-\mathrm{M}-\mathrm{Al}$. At still higher concentrations the steepness of the wave becomes less; the logarithmic analysis fits the foot of the wave is maintained even at these concentrations. The dependence of the half-wave potential on the drop-time and on the rate of flow of mercury was measured at a concentration of $3 \cdot 8 \cdot 10^{-3} \mathrm{M}$ of aluminium, where the maximum is relatively small and the half-wave potential well defined. With increasing drop-time and with decreasing rate of flow of mercury the half-wave shifts towards positive potentials (by about $20 \mathrm{mV}$. This shift of the wave and by about $10 \mathrm{mV}$ for $m=2 \mathrm{mg} / \mathrm{s}$ to $m=1 \mathrm{mg} / \mathrm{s}$. Ihcentrations.

Addition of gelatin suppresses the autocatalytic nature of the current as All as the trolatin suppresses the altions of aluminium ions the addition of $0.01 \%$ of rolatin restores the usual monotonous shape of the $i-t$ curves corresponding to the irreversible electrode reaction; at the same time the polarographic $i-E$ curve loses its steepness.

The shift of the polarographic wave towards negative potentials is also caused by increasing concentration of the supporting electrolyte (with the exception of lithium salts, for which the shift oceurs in opposite direction), The magnitude of the shift depends on the cation. Tn 0.1 s sole wave potentials are practically the same, in $1 \mathbb{N}$ supporting electrolytes conat $-1.610 \mathrm{~V}$ in $0.1 \mathrm{~N}$ solutions of chlorides at $20^{\circ} \mathrm{C}$. In $1 \mathrm{~N}$ solutions the half-
Poltrographic Wrave of Aluminium

wave potentials are as follows: $\mathrm{LiCl}-1.575 \mathrm{~V} ; \mathrm{NaCl}-1.625 \mathrm{~V}$; $\mathrm{KCl}-1.665 \mathrm{~V}$; A strikin of complex forming substances to the solution (Fig. 10). With sulphates we must increase the concentration over $0 \cdot 1 \mathrm{M}$, with fluorides, oxalates, tartarate (cr. ${ }^{23}$ and citrates it is sufficient to add amounts equivalent to the aluminiun ion concentration to obtain the same effect. In all cases with successive additions of reagents the autocatalytic part of the wave as well as the maxima disappear; finally simple diffusion-controlled polarographic wave ol a constant herrent of the supporting eloctrolyte. A similar change in the curves may be observed when increasing the amount of enthanol in the solution: autocatalysis and the maximum disappear and a simple wave remains starting at slightly more positive potentials. In a $90 \%$ ethanolic solution there appear one more positive wave; both the waves are dimfision-controlled (Fig. 11). On the other hand additions of alkaline hydroxides have a similar effect as when merely diluting the solution; we obtain a reversed sequence of curves

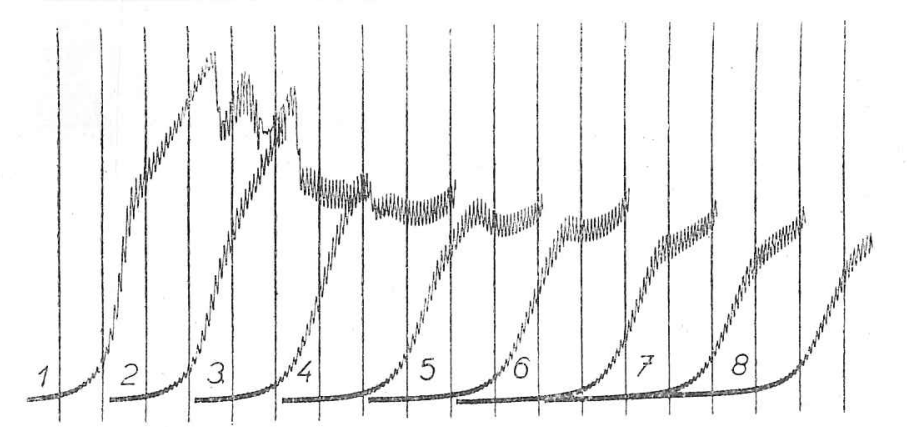

Fig. 10

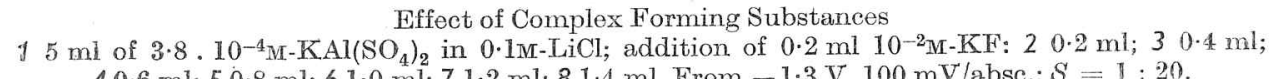

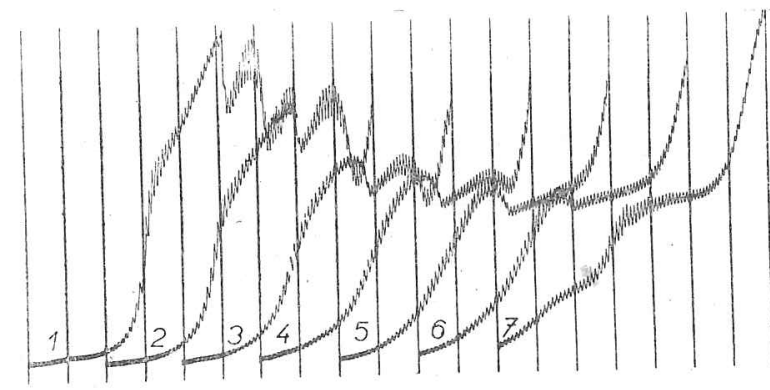

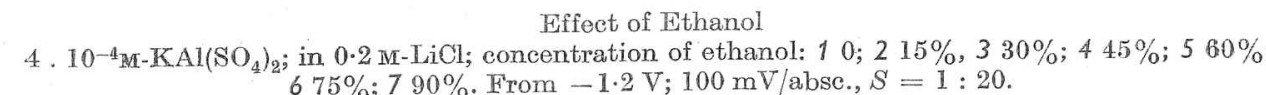


Addition of aluminium salts into unbuffered solutions of substances polarographically reducible under consumption of protons causes an analogous effect as the addition of mineral acidss. Even a catalytic wave of hydrogen evolution due to some organic compounds oceur in presence of aluminium ions

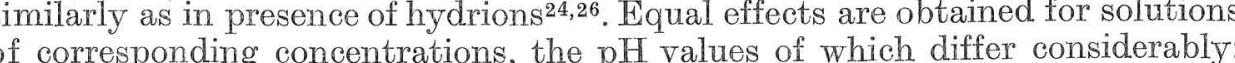
of corresponding concentrations, the $\mathrm{pH}$ values of which differ considerably: the same extent as $10^{-3} \mathrm{M}-\mathrm{H}_{2} \mathrm{SO}_{4}(\mathrm{pH} 2 \cdot 8)$.*

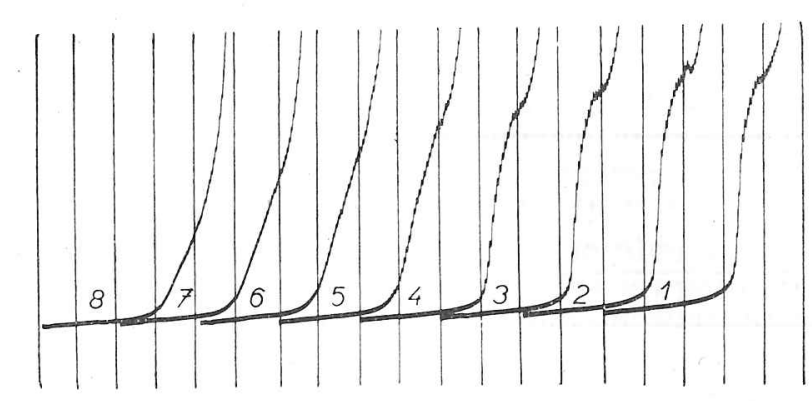

Fig. 12

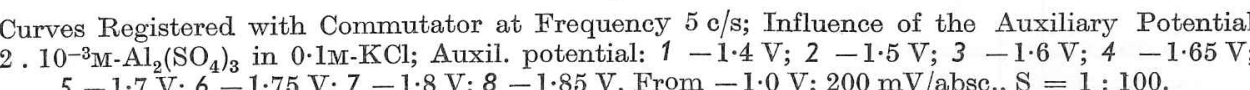

The curves of aluminium salt solutions registered with the commutator by Kalousek do not show any anodic wave even at the frequency of $32 \mathrm{c} / \mathrm{s}$. If the auxiliary potential is shifed to the negatises, becomes drawn-out and indi-

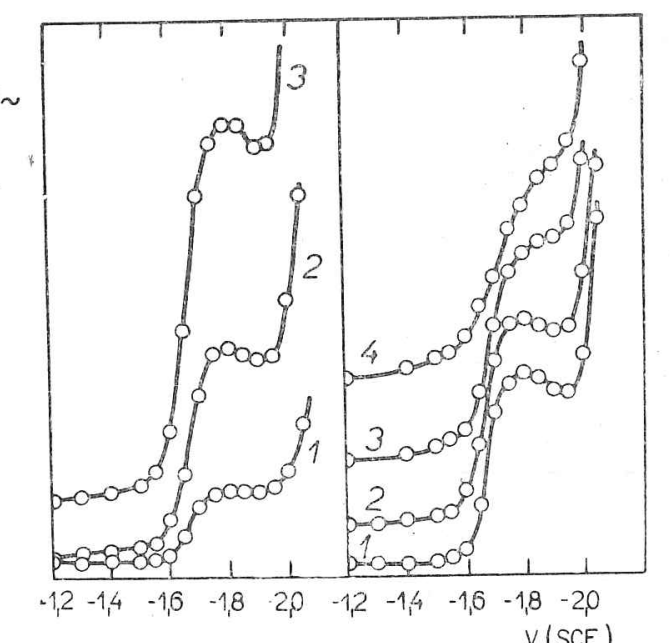
ishes, becomes drawn-out and indithe same time towards positive poentials (Fig. 12)

Fig. 13
A. O. Polarograms of $3 \cdot 8 \cdot 10^{-3} \mathrm{M}-\mathrm{KAl}\left(\mathrm{SO}_{4}\right)_{2}$ Influence of the amplitude of alternating

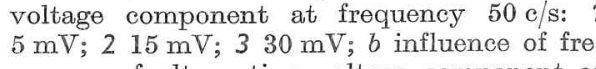
quency of alternating voltage component at
the amplitude $15 \mathrm{mV}: \quad 120 \mathrm{c} / \mathrm{s} ; 2 \quad 50 \mathrm{c} / \mathrm{s} ;$
$3100 \mathrm{c} / \mathrm{s} ; 4 \quad 200 \mathrm{c} / \mathrm{s} ;$

$\checkmark(S C E)$
T. Heyrouslin:

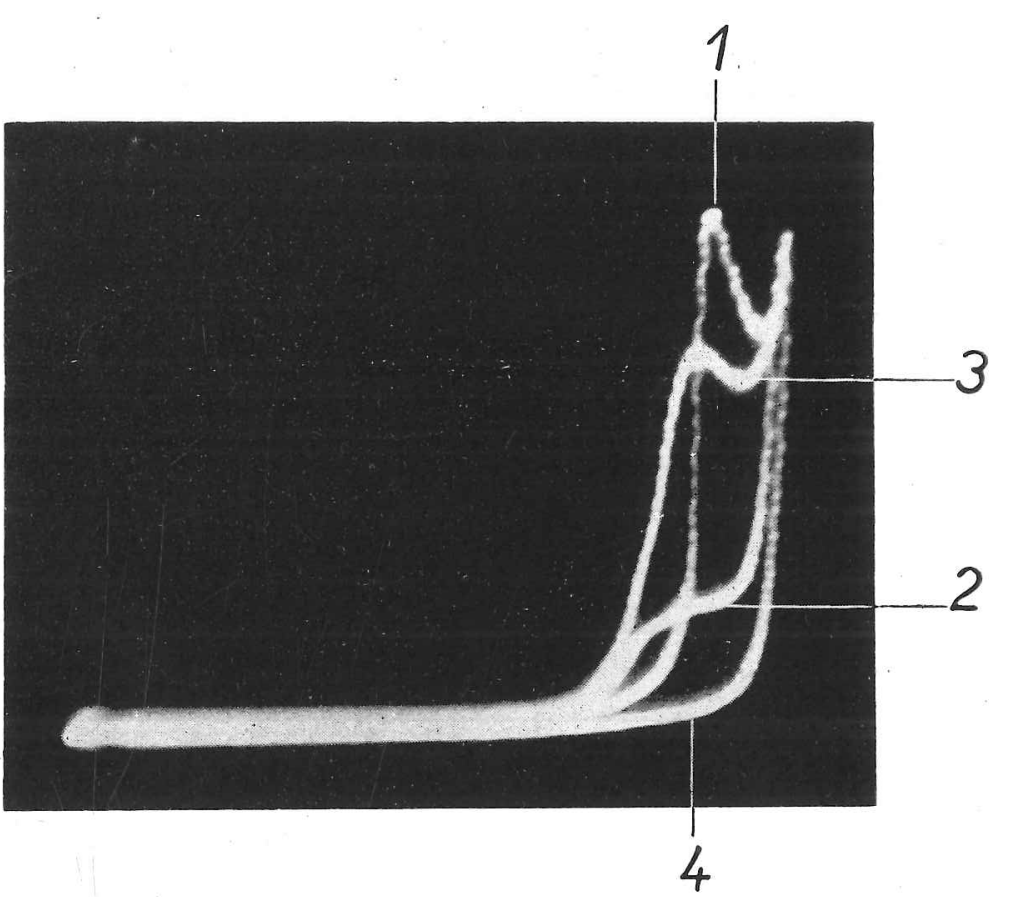

Fig. 16
Oscillographic $i-E$ Curves with Triangular Voltage Impulses

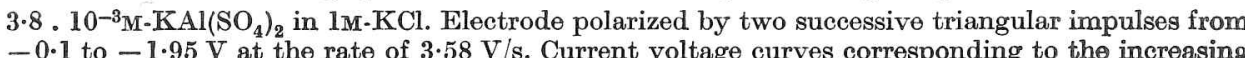
and decreasing phases of the impulses follow in the order $1,2,3,4$

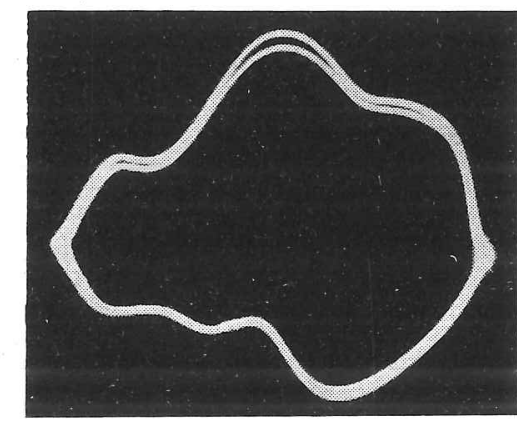

Fig. 18

* The behaviour of chromic ions (at potentials more po
$\mathrm{Cr}^{3+}$ ) was found to be analogous to $\mathrm{Al}^{3+}$ ions in this respect. 
A. C. polarographic curves of $\mathrm{Al}^{3+}$ ions registered with various frequencies and amplitudes of the alternating voltage component reveal peaks of an unu sual reduction (compared with $\mathrm{Tl}^{+}$) (Fig. 13). The height of the peak is not a linear function of aluminium ions concentration but it reaches a limit. (Paralelly re gistered peaks due to hydrogen ion reduction from hydrochloric and acetic acids are strictly proportional to the concentration).

Ordinary current-voltage cur-

ve obtained with the streaming electrode looks like composed of two different waves: at the belowly with the applied rolte then the wave attains a steep slope, steeper than a two-electron reversible reduction (Fig. 14).

Fig. 14

Polarographie Curve of $1 \cdot 2 \cdot 10^{-3} \mathrm{M}-$
$\mathrm{KAl}^{-}\left(\mathrm{SO}_{4}\right)_{2}$ in $1 \mathrm{MM}-\mathrm{LiCl}$ on the Streaming Dashed lines indicate the hypothetical curves of two separate processes, a 3 -elec-

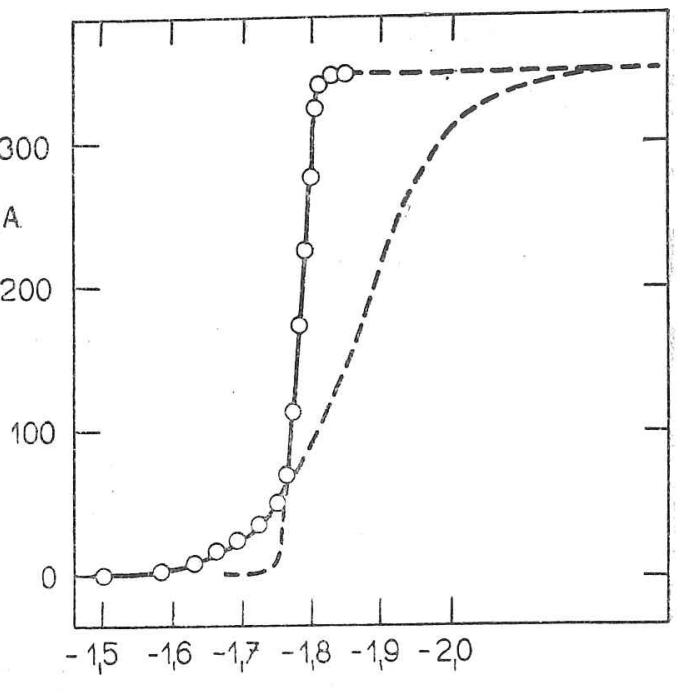

With the hanging drop electrode aluminium ions give a current-voltage wave of a smaller slope than a reversible one-electron reduction, but steeper its shape depend on the state of the electrode surface; with a fresh surface it

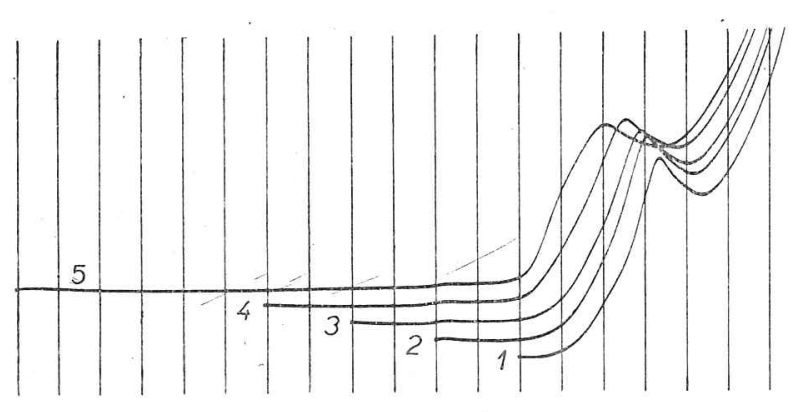

Fig. 15

Hig. Hanging Mercury Dro

3.8. 10-4-1M-KAl(SO $\left.\mathrm{S}_{4}\right)_{2}$ in $0.1 \mathrm{Mr}-\mathrm{LiCl}$. Effeet of time on peak potential: Curves registered from 
Heyroovsḱy:

depends on how long the electrode has been in contact with the solution before polarization (Hig. 15). The longer the drop hangs in the solution, either under an applied porential or not, the more positive is' the wave. 'This shith has it limit at the potential of reduction of hydrogen ions from a strong acid beginning ith the solution prior to its polarization. In comparison with the curve registered immediately after dipping the electrode into the solution the curve registered after ten minutes is shifted to positive potentials by approximately $130 \mathrm{mV}$. This time effect does not occur in the presence of gelatin.

A similar, only less pronounced, influence of time of eontact of the electrode with the solu-
tion on the shape and position of the wave may be observed for beryllium, scandium and

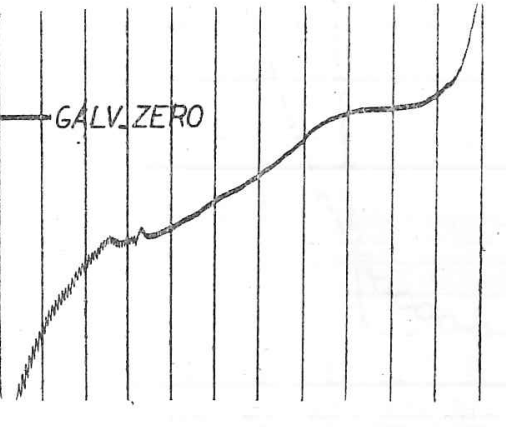

Fig. 17
Anodic Curve of Aluminium Amalgam Di

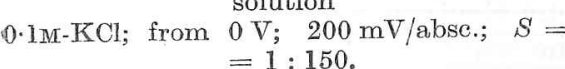
Repeated cyclic polarization, both slow (by means of a polarograph) and

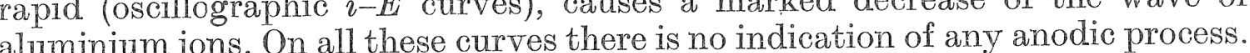
At the ascens. On alt a a rapid polarization pulse (from $3 \mathrm{~V} / \mathrm{s}$ ) the curve is At the ascending palarization cycle and the foot of the wave is by 200 to $300 \mathrm{mV}$ more negative than at the descending branch of the pulse and at all following cycles (Fig. 16*)

Oscillographic curves obtained by polarizing the dropping mercury electrode by alternating current or voltage at a frequency of $50 \mathrm{c} / \mathrm{s}$ do not show any depolarization due to aluminium ions. A slight difference from the curve for pure supporting electrolyle appoars at negave

A specific effect, appears with the cyclic polarization of the mercury electrode If besides aluminium ions also lithium ions are present in the solution. This cussed in this general treatment.

* See insert facing p. 3128
Polarographic Wave of Aluminium

Aluminium amalgam in aqueous solutions gives a drawn-out anodic wave (Fig. 17). Oscillographic alternating current and alternating voltage controlled curves show irreversible anodic dissolution of the amalgam (Fig. 18*). The electrocapillary curve in a $10^{-3} \mathrm{M}$ solution of $\mathrm{KAI}\left(\mathrm{SO}_{4}\right)_{2}$ differs from the curve obtained for pure $0 \cdot 1 \mathrm{~N}-\mathrm{LiCl}$ by steeper branches. This is clearly shown after differentiation of the eloct lines the slope of which has the dependence of $\mathrm{d} \gamma / \mathrm{d} E$ on $E$ gives two straight lines the slope of which has the physical meaning of the of the electrocapillary parabola the slope of the line increases in the presence of aluminium ions in the ratio $7: 6$.

\section{Discussion}

The existence of hexaquoaluminium ions in diluted aqueous solutions of luminium salts is generally accepted in ehemical literatureas. Hydrolysis is due to the acidic properties of tin a much narrower range of potentials), like proton donors in reduction reactions in which hydrogen ions are consumed. The reduction wave proper of aquo-aluminium ions has many properties of a reduction wave of hydrogen ions from weak acids. It is known that the potential of aluminium electrode becomes more positive with increasing acidity of the solution $^{45}$; the polarographic wave, on the contrary, shifts to more negative values; this can be explained by the supp con of complex. This can account for thititively the same effect as was found by Tomeš 46 .

The influence of eations of the supporting electrolyte on the reduction The influence of cations of the supporting electrolyte on the reduction the sequence of action of alkali metals and alkaline earth cations is the same as with aluminium. The temperature coefficient of about $+3 \mathrm{mV}$ per degree of the half-wave potential is unusually high; such a value is reported for the potential of a $45^{\circ}$ tangent of the hydrogen wave. The bubbles of gaz observable at the surface of the electrode can be ascribed to the hydrogen ovolved. At stationary electrode the cathodic wassolution of alupositive by a algam in the same solution. The total irreversibility of the electrode process was proved by experiments obtained with the stationary electrode with the commutator of Kalousek as well as from the results of the method

by Breyer and from oscillographic curves.
Since the height of the wave corresponds to a 3-electron reduction, it follows that the hexaquoaluminium ion acts as a tribasic acid. The single and continuous polarographic wave indicates that the values of all the three dissociation constants are nearly of the same magnitude, $15^{\circ} \mathrm{C}$. The potential of the wave is near to that of the wave of acetic acid with the dissociations conis near to that of firm the proposed scheme of the electrode reaction:

$\mathrm{Al}\left(\mathrm{OH}_{2}\right)_{6}^{3+}+3 \mathrm{e} \rightarrow \mathrm{Al}(\mathrm{OH})_{3}+3 / 2 \mathrm{H}_{2}+3 \mathrm{H}_{2} \mathrm{O}$

* See insert facing p. 3128.

Vol, $25(1960)$ 
Heyrovskés:

At concentrations of aluminium ions of the order of $10^{-5} \mathrm{M}$, logarithmic analysis of the wave gives results similar to those obtained by Kut ta $^{51}$ for the upwards the wave begins to differ from At this concentration the limiting diffusion current reaches the value of about $3 \cdot 5 \cdot 10^{-7} \mathrm{~A}$, when inside the diffusion layer of the thickness of $5 \cdot 10^{-3} \mathrm{~cm}$ and the precipitate remin hydroxide is exceeded within the drop time of $2 \cdot 6$ of a new phase at the electrode surface disturbs the surface. The appearance what causes the motion of the surface*. Solid aluminium hydroxide is a stury adsorbent which is able, thanks to its amphoteric nature, to adsorb the acidic as well as the basic components of the solution ${ }^{62}$. The adsorbent influences the dissociation equilibria at the electrode surface and this fact appears to be the cause of differences between a simple reduction wave of hydrogen ions

The kinetic character of the maximum and its sensitivity to $\mathrm{pH}$ of the soluwater split off from it through the is due to the reduction of hydrogen ions from the case of water molecules the adsorbent reacts with othere. Similarly as in influence of stronger acids may be explained by oceupation of free plas. The the surface of adsorbent by protons from the solution, which are then reduced at the maximum. This view is supported by the fact that the height of the maximum reaches a limit at high concentrations of $\mathrm{H}^{+}$-ions.

Aluminium hydroxide as the reaction product acts eatalytically, but on the other hand it occupies part of the electrode surface and thus slows down the reaction. Contrary to this the growth of the drop renews the surface. Further, may change new aluminium ions, of the adsorbent as a result of the reaction minium hydroxide which then contributes to the eatalytic action. The alutrary tendencies alternatingly prevailing in the electrode process may ase confor the formation of the irregular sharp cuts in the $i-t$ curves at potentials of the polarographic maximum.

At the potential at which the maximum falls to the three electron height the adsorbed layer changes probably its structure and loses the catalytic activity, analogously with the mechanism, assumed in usual cases of the catalytic hydroafter the fall of the Only above $2.10^{-4} \mathrm{M}$-A $\mathrm{A}^{3+}$ a new catalytic wave appears duction of hydrogen ions by a different mest probably due to catalytic rein the second maximum is caused by saturation of the vicinity of current trode with reaction products, probably with aluminium hydroxide and hydroxyl ions, and by their transfer to the following drops.

Gelatin added to the solution occupies the electrode surface. It does not ffect the reduction of hydrogen ions from the aquocomplex but it hinders thet formation of the precipitate and thus affects its catalytic activity, and the characteristic maximum is suppressed. An analogous influence of lanthanum. lons can be explained by an inhibitory action on catalytic properties of $*$ A similar effect may be observed at positive potentials in solutions of chlorides when a film
of calomel is formed at the electrode. 3132
Polarographic Wave of Aluminium

With the increasing concentration of aluminium ions the point on the polarographic curves, corresponding to the beginning of formation of solid the foot of the wave. At about $\left.2 \cdot 10^{-4} \mathrm{M}-\mathrm{A}\right]^{3+}$ the formation of solid hydroxide begins at about 1/10 of the total height of the wave, where the electrode reaction proceeds practically without concentration polarization. The autocatalytic character of $i-t$ curves shows that aluminium hydroxide affects even the reduction of hydrions from the hexaquoaluminium complex. This property of the freshly precipitated aluminium hydroxide is also evident from the results with commutator and from oscillographic $i-E$ curves; the hydroxide to me electrode reaction freshly precinitated potentials. The catalytic activity can be observed only on Aluminium ions as such adsorbed at the necative interface, crystals are formed. electrocapillary curves (see also ${ }^{53}$ ), do not show any catalytic effect on reduction of hydrogen ions from other acids. The same negative result gives aluminium. hydroxide prepared separately and added into the solution.

The hindering effect of the layer of aluminium hydroxide on electrode reactions is evident from the results with alternating polarization of the electrode. enciliely suphe curves indicate formation of the layer which after 6-10 cycles entirely suppresses the reaction proper of aluminium ions. On the curves reason with the shift of the auxiliary potential towands nesative vas same which the electrode is covered with hydroxide. Similarly the a. c polarograms indicate that the electrode process is followed by adsorption of the reaction product preventing the linear increase of the peak with concentration. In this way the autocatalytic nature of the reaction and its slackening by the reaction products together with the constant formation of the fresh electrode surface leads to a periodic electrochemical reaction. These principles
are common for periodic chemical reactions increase of current at the ascending part of the wave is the Autocatalytic aluminium wave is steeper than the hydrogen wave. Gelatin suppresses the action of aluminium hydroxide and reduces the steepness of the wave. At higher concentrations of aluminium ions the hindering effect of the adsorbed layer prèdominates and the increase of current in the ascending part is slowed down. The influence of the adsorbed layer of aluminium hydroxide on the rate of flow of merewry which has not bee of the half-wave potential on the the hydrogen

At the surface of the stationary electrode there accumulates a species which makes the following reduction easier. As the time effect is the same whether electrically neutral. It is most probably again aluminium hydroxide, always present in minute quantities in aqueous solutions of aluminium ions, which is adsorbed at the electrode surface. There it may form small islets of solid phase, acting catalytically in the same way as observed in other experiments. Gelatin suppresses the catalytic effect by occupying the surface as a more obtained with the hanging electrode aluminium wave to positive potentials of hydrogen ions from strong acids. This shows that the catalytio action of 


\section{Heyrovsky:}

aluminium hydroxide does not consist in affecting the reduction proper of the proton, but probably in setting free the proton from its bond in the proton donor. Such a concept would agree with ideas about the influence of adsorption

At $h$ gher contents of alcohol in solution the catalytic maximum is suppressed, probably as a result of the suppression of dissociation of week acids in dissociation constants ${ }^{56}$, the first wave in $90 \%$ ethanol belongs probably to the first hydrcgen ion dissociated from the complex.

On addition of complex forming anions the aquocomplex is changed into different complexes which have no more hydecg nn ions to be split off. Thi is the reasson why the maximum and autocatalysis disappear. In the new wave the central aluminium ion is probably reduced directly to the metallic state ahis would explain the shift of the new wave to negative potentials with further turns the aquions direetly into polaregraphically inative particles of al,

At the streaming electrode the time of contact between the solution and the electrode surface is too short to let the reaction product affect the reaction process. The reduction curve of hydrion from a strong acid has the same slope at the streaming as at the dropping mercury electrode, but it shifted minium wave seems to correspond to the reduction of hydrogen ion, but at of the aluminium ion. The inte of this reaction increases more the potential and so it soon prevails over the hydrcon ion reduction. Thit allows us to suppose that even with the dropping mercury electrode, at sufficiently negative potentials, the direct reduction of aluminium cation takes part in the electrode process (ef. ${ }^{27}$ ). The abrupt fall of the polarographic maximum denotes probably the potential at which the reduction to the metallio state predominates. As the whole process is irreversible even at high frequencies of alternating polarization, the metallic aluminium must underg'? a rapid in differs probably from that formed in reduction of hydrog on ions; this would alytic activity of the film at different potentials of the aluminium wave.

Between aluminium and other cations an analogy in polarographis behaviour may be found
in various respects. Similarly to aluminium behave beryllium and scandium ions which indicates analogous forms of complexes in solution 5 si, bs, as well as similar properties of hydroxides of these counted for by the stepwise dissociation of the thorium aquocomplex ${ }^{5}$. Judging from the date given in literature (for a review se $e^{60}$ ) and from autocatalytici $i-t$ curres obtained for the re-
duction waves of rare earth elements it may be supposed that similar factors as described for
aluminium play role in the respective electrode reactions.

References

p. 102. Pitman, London 1949 2. Prajzler J.: This Journal $3,406(1931)$.
3. Gokhstein J. P.: Zavodskaja lab. $5,28,158$ (1936).

3134

Collection Czechoslov, Chem. Commun
Polarographic Wave of Aluminium

Hövker G.: Dissertation. Hansische Universität, Hamburg 1938.

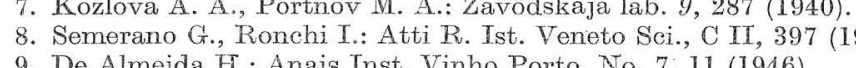

Payne S. T.: Rept. No. 729, p. 17, Brit. Non-ferrous Metals Research Assoc., London 1947.

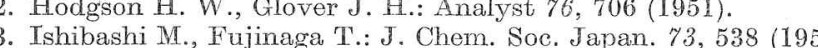

Proszt J., Paulik J.: Magyar Kém. Folyóriat $58,113(1952)$

Page J. A., Simpson D. H., Graham R. P.: Anal. Chim. 41 41 (1955).

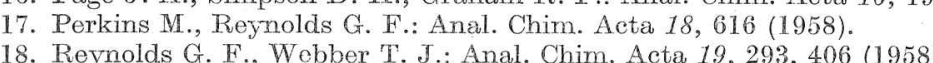

18. Reynolds G. F., Webber T. J.: Anal. Chim. Acta 19, 293, 406 (1958).
19. Stackelberg M. V.: Polarographische Arbeitsmethoden, p. 116. W. de Gruyter, Berlin 1950.

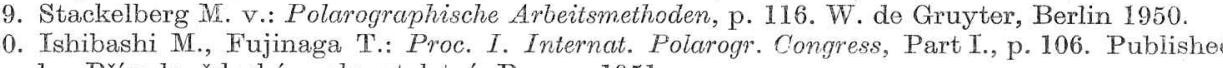

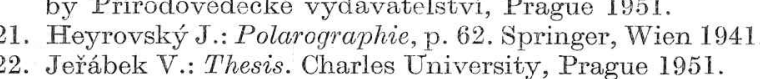

23. Zuman P.: Chem. listy 46,326 (195

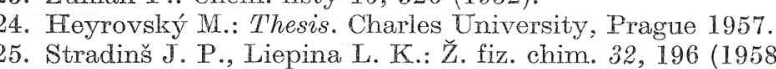

26. Heyrovský M.: Z. physik. Chem. (Leipzig), Sonderheft Juli 19.j8, 97

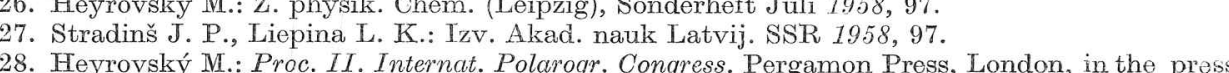

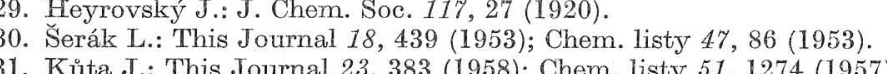

31. Kủta J.: This Journal 23, 383 (1958); Chem. listy 51,187 Kemula W., Kublik Z.: Anal. Chim. Acta 18, 104 (1958)

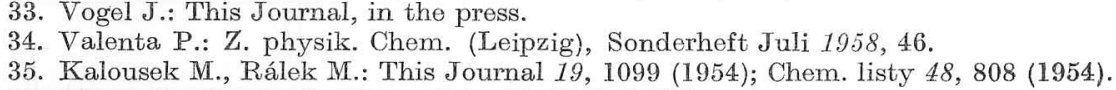

36. Némec L., Smoler I.: Chem. listy 51,1958 (1957).
37. Kalvoda R.: Chemie 10, 529 (1958)

37. Kalvoda R.: Chemie 10,529 (1958).
38. Ruetschi P.: Trumpler G.: Helv, Chim. Acta $35,1021,1486,1957(1952)$
39. Heyrovsky J J.: This Journal 18,749 (1953); Chem. listy 47,1762 (1953).

40. Kemula W., Kublik Z:: Roczniki Chem. 30,1005 (1956).
41. Kemula W., Kublik Z:: Roczniki Chem. 30,1259 (1956).

42. Keyrovský, M.: Roczniki Chem. 31, 1083 (1957).

43. Kemula W., Kublik Z.: Roczniki Chem. 31 , 1085 (1957).
44. Pokras L.: J. Chem. Educ. 33; $152,223,283$ (1956).

44. Pokras L.: J. Chem. Educ. 33, 152, 223,
45. Smits A.: Z. Elektrochem. $30,423(1924)$.

46. Tomeš J.: This Journal 9,150 (1937).

47. Herasymenko P., Slendyk I.: Z. physilk. Chem. A 149, 123 (1930).

48. Nejedly V.: His Journal 1, 319 (19.

Conway E.: Electrochemical Data, p. p. 184. Elser. 134, 97 (1928).

51. Kủta J.: Thesis. Charles University, Prague 1950.

53. Vorsina M., Frumkin A. N.: Z. A fiz. chim. 17, 295 (1943)

54. Peard M. G., Cullis C. F. Trans. Faraday Soc. 47,616 (195)

55. Kủta J., Drábel J.: This Journal 20, 902 (1955); Chem. listy 49,23 (1955).

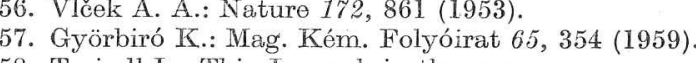

58. Treindl L.: This Journal, in the press.;
59. Mašels J: This Journal 24, 159 (1959); Chem. listy 52,7 (1958)

60. Treindl L.: This Journal 24, 3389 (1959).
61. Treind L: This Jounna 25, 1127 (1960).
62. Pryor M. J.: Z. Elektrochem. 62, 782 (1958).

Translated by the Author. 


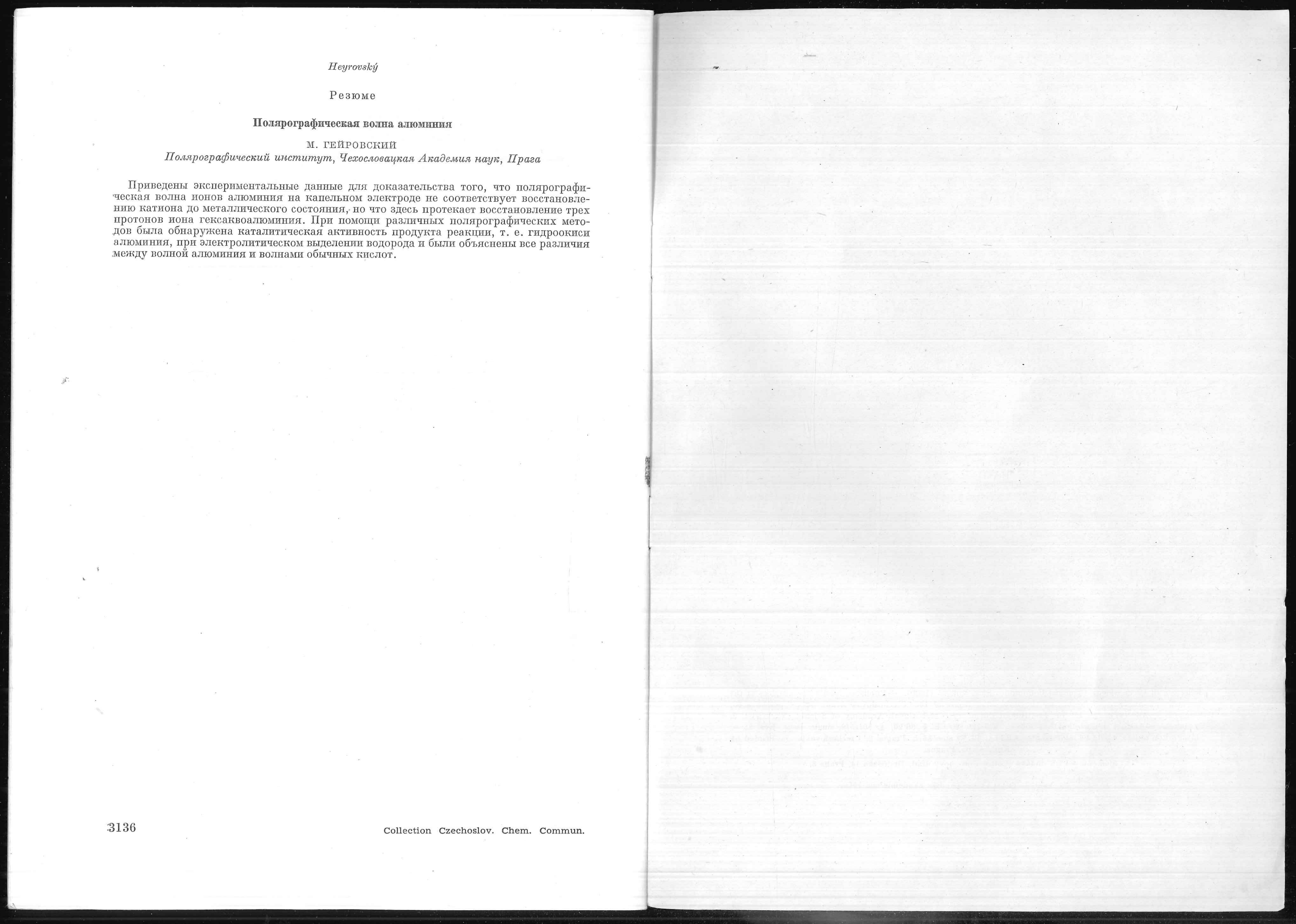


Anodic photocurrent and the primary

Process in Electrochemical Photoeffect

Avonto whotocurrents are often produced when polarized mofalls electrodes covered with oxide or other semiconducting material are ifluminated in solutions ${ }^{1}$, The primary process is here the generation of a pair electronhole, which results from the absorption of a light quantum in the surface layer.

A different kind of anodio photocurrent has been found in the case of a dropping mercury electrode illuminated by light not absorbed in the solution. This was observed in solutions of glyoxal, diacetyl, sodium oxalate, dimethyl oxalate, oxalic acid, pyruvic acid, glycine, Cl-acetic acid and as series of $\alpha$-hydroxy acids. The condition of activity is apparently the prescrice of a $\mathrm{C}=0$ group in the molecule with a negative substituent on the neighbouring arbon atom. In solutions of compounds giving polarographic anodic currents due to formation of complexes with mercury, such as ethylenediamine tetraacetic acid or ethylenediamine, the anodic photocurrent does not appear:

In a similar fashion to cathodic photocurrents on the dropping mercury electrode $e^{2,3}$, anodic photocurrents are directly proportional to the surface of the olcetrode and to the intensity of light; the relation between the energy of the red limit of photocurrent and the potential of the electrode is linear (Fig. 1). However, unlike their effect on cathodic photocurrents, aqueous and ethanolic solutions yield ariodic photocurrents of the same order of magnitude.

Sinee the absorption of light in the bulk of the solution has been excluded in the present experiments and since the absorption by the metallic surface should lead to cathodio photoemiasion of electrons, there is onty one

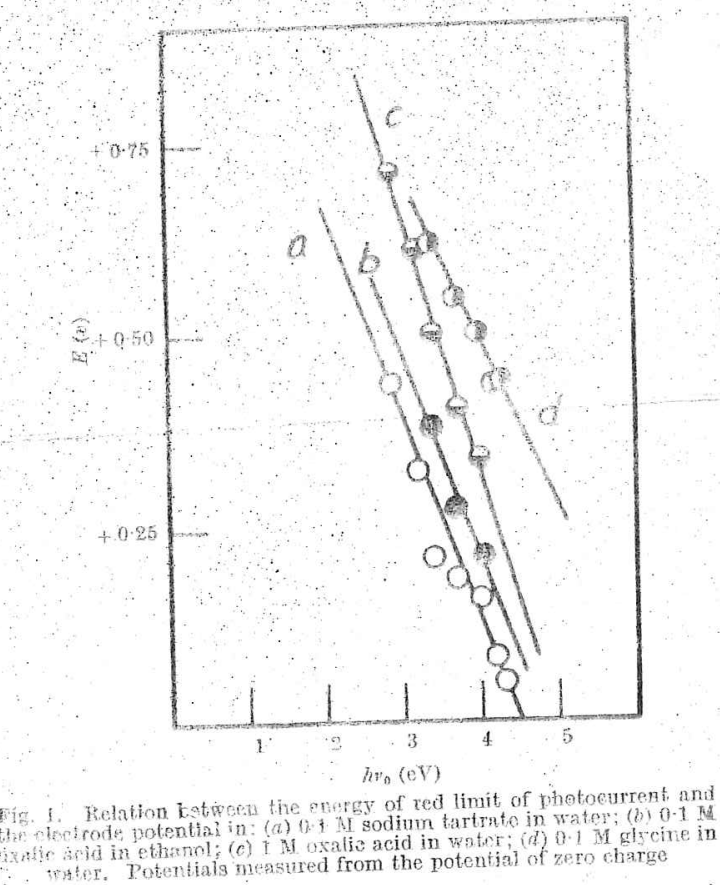
posible explanation that the light-absorhing species peponsible for the and orgaris compound and the surface of tis electrode.

The mechanism of photopxcitation of such a complex fon interpreted in terms of the charge-transfer no-bond can be interpieted in therme applied to adsorption. The electrode plays the theory applied to adsorption " The electrode plays the part of an electron acceptor, the organic molectiles are electron donors, and the adsorption bond corresponds to the ground state of the complex. On absorption of light quantim the electron is transferred from the adsorber substance to the electrode. If the electron returns to the ground state, no direct current can be observed. The occurrence of a photocurrent indicates, therefore, that the complex in its excited state has undergone som secondary irreversible change. In the example given hese, this change is probably an electrolytic oxidation of the dative state of the donor.

In solutions of sodium oxalate, for oxample, judging from the photochemical behaviour of oralate complexes of mercury ${ }^{5}$, it can be assumed that from the oxalate anion of mercury ${ }^{5}$, it can be assumed that rationt-anion $\mathrm{C}_{2} \mathrm{O}^{-}$is in the dative state the oxalate radicat-anion $\mathrm{C}_{2} \mathrm{O}_{4}$ formed which, as a strong reducitig dioxide, thus yielding the anodic current.

The photoexcitation of a charge-transfer complox between the electrode and an adsorbed substance might also explain the primary processes in the cathodic photo. also explain the primary processes in the electrons is rant current in cases where direct emission of electrons is
likely to occur, as it has been observed in aquams solutions ${ }^{2,3}$,

I thank Imperial Chemical Industries, Ltd., and the British Petroleurn Co, for grants:

Deps,rtment of Physical Chemistry,

M. Herrovsky

University of Cambridge.

* Present address: The J. Heyrovský Polarographic Institute, Crecho slovak Academy of Seiences, Vlašská 9, Prague 1.

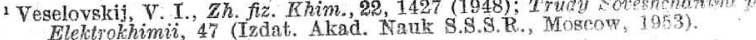

a Heyrovský, M., Nature, 206, 1356 (1965).

s Heyroysky, $M$. (in preparation).

Mran $\mathrm{F}$ A Makrides, A, C. nnd Hackerman, N., J. Chem Phys., as 1800 (1954).

Bisikalova N A, Derain. Khim Zh, 18,815 (1951)

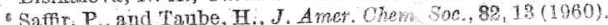

7 Abel, Ei, Monatsh. Chem., 83, 695 (1952). 
3a. Vorsina M., and Frunirin A. N. Zhur. fiz. Khim. 17, 295-309, 1943

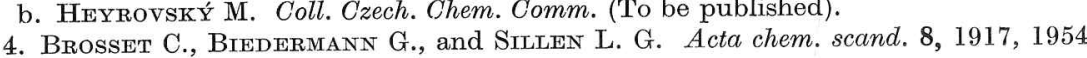

5. HeYrovskÝ J. Chem. Listy 47, 1762, 1953.
KenuLA W., and KUbs.r Z. Roczniki Ohem. 30, 1005, 1956; 31, 1085, 1957.

DISĆUSSION

B. B. BACH: Has the work on the polarography of aluminium led to a method

M. HFYROVSRY $\dot{x}$ : The height of the wave is proportional to concentration but therference may be experienced from the $\mathrm{H}$ wave. The use of Eriochrome o Solochrome dye methods would probably be preferable. 


\section{POLAROGRAPHY OF ALUMINIUM}

\section{By M. Heyrovshy}

Polarographic Institute of the Czechoslovalk Academy of Sciences, Prague

ALUMINIUn ions exist in diluted aqueous solutions with co-ordinated six molecules of water, thus forming a hexaquoaluminium ion ${ }^{(1)}$. This ion behaves like a weak acid of $\mathrm{p} K$ about $4 \cdot 9$, capable of dissociation of altogether 3 protons, changing in this way into aluminium hydroxide. The acidic properties of the hydrated aluminium ion explain many strange points in its polarographic behaviour are slightly acidic because of hydrolysis, the aluminium ion gives a totally irreversible polarographic reduction wave, with the half-wave potential at about $-1.7 \mathrm{~V}$ (SCE), the shape and position of which depends on many factors. With increasing concentration or acidity the wave shitts toward more negative potentials, like the hydrogen wave of a weak acid, whereas from potentiometric measurements it is known that the potent ial of the aluminium electrode gets more positive with deos cases of metallic ion reduction, the temperature coefficht of the $7 \times 10^{-4}$ potential is positive and unusually high, at the being $+3 \mathrm{mV} /$ grade, tho samo valuo is lat hydrogen ion.

hen added to the solution of organic depolarisers, the aluminium ion has the same effect as hydrogen ion on their reduction waves - it causes a shift to more positive potentials and with som in the pecifo influee of the gen it gives a catalytic hylogen cations of the sapporing eloctrolyte potentials in the sequence $\mathrm{Li}<\mathrm{Na}<\mathrm{K}$ and $\mathrm{Ng}<\mathrm{Ca}<\mathrm{B}$. Toreover, by close analogy betweon the alu $<$ and bubles of hydrogen may be means of a mictosope tho erf All the facts lead to the conclusion that the reduction of hydrogen ions All these facts lead to the conclusion that the reduction of hydrogen ions from water molloulcs to the conted the the a reaction giving the plo $\left[\mathrm{Al}\left(\mathrm{OH}_{2}\right)_{6}\right]^{3+} \stackrel{3 e}{\rightarrow} 3 \mathrm{H}+\mathrm{Al}(\mathrm{OH})_{3}+3 \mathrm{H}_{2} \mathrm{O}$

However, a mere inspection of the shape of aluminium wave registered a
POLAROGRAPHY OF ALUMINIUM

ifferent concentrations shows that the whole electrode process is much more complicated than a simple hydrogen-ion reduction (Fig. 1).

At the concentration of about $6 \times 10^{-5} \mathrm{M}$ there appears on the curve maximum, the height of which depends linearly on the square root of the height of mercury reservoir. The maximum remains at all concentrations a

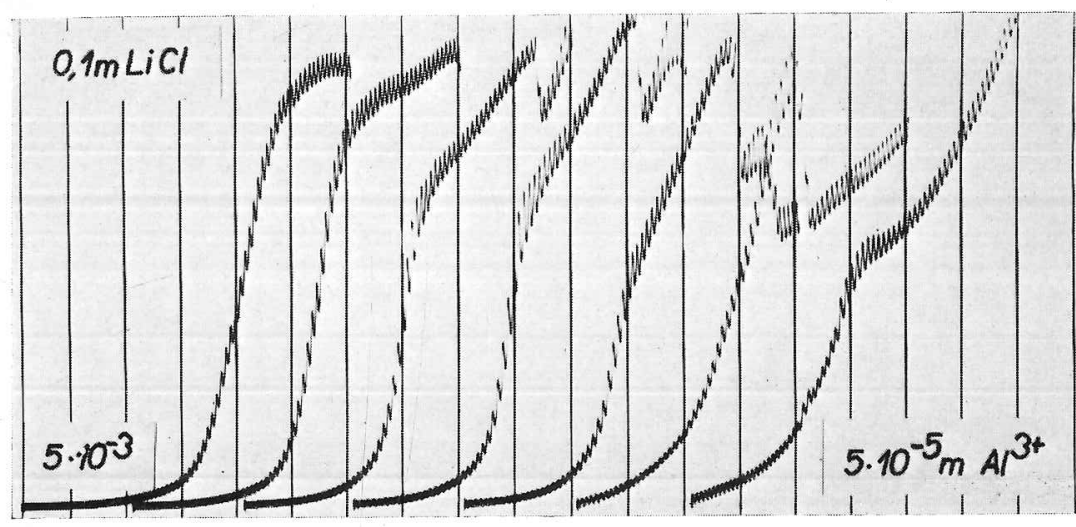

Fra. 1. Polarographic curves of $\mathrm{Al}^{3+}$ in $0.1 \mathrm{M} \mathrm{LiCl}$ at various concentrations.
From right to left: $5 \times 10^{-5}, 1 \times 10^{-4}, 3 \times 10^{-4}, 5 \times 10^{-4}, 7 \times 10^{-4}, 2 \times 10^{-3}$, $4 \times 10^{-3} M \mathrm{MAl}\left(\mathrm{SO}_{\mathrm{A}}\right)$; ; eurves registered from $-1 \cdot 3 \mathrm{~V}$; $100 \mathrm{mV} /$ absc.; anode-
saturated calomel; sensitivity reduced stepwisely from $1 / 3$ to $1 / 200$; oxygen

removed by $\mathrm{N}_{2}$.

a characteristic mark of the aluminium wave; its height limits to a fiveelectron reduction at low concentrations, decreasing slowly to three as the concentration increases. After reaching a maximum the current falls rapidly down to a three-electron height. At potentials where the maximum exceeds three electrons, there appears a distortion of the $i-t$ curves in form of acut indentations (Fig. 2). When the maximum falls off, the $i-t$ curves indicate an adsorption of a permeable film taking place at the beginning of the

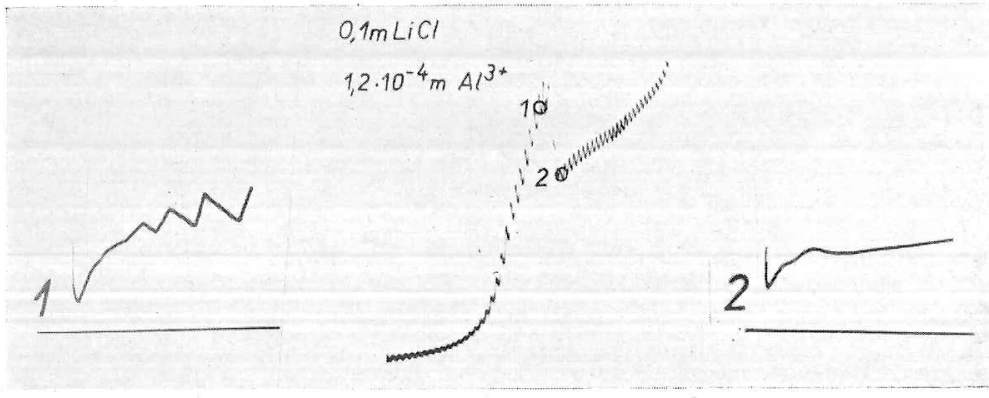

FIG. 2. Polarographic $i-E$ curve of a $1 \cdot 2 \times 10^{-4} M$ solution of $\mathrm{KAl}_{(\mathrm{SO}} \mathrm{S}_{4}$ in
in $0 \cdot 1 \mathrm{M}$ 
drop-time (Fig. 2). This phenomenon may be explained as follows: when at the surface of the electrode a stepwise reduction of hydrogen ions proceeds a new reaction begins, the direct reduction of the aluminium-ion from the partly hydrolysed complex to the metallic state: one trivalent cation can in this way accept at most five electrons; two can be accepted by the two protons, dissociated without precipitation from the hydrated complex, and the remaining three are used up in the reduction of the ion itself. The reduction of the metallic ion from a partly hydrolysed aquocomplex is accompanied by the liberation of $\mathrm{OH}^{-}$-ions which cause precipitation of aluminium hydroxide at the electrode surface- hence the indentations in the $i-t$ curves. Thus, in the middle part of the polarographic curve there are two electrod

$\left[\mathrm{Al}\left(\mathrm{OH}_{2}\right)_{6}\right]^{3+} \stackrel{n e}{\rightarrow} n \mathrm{H}+\left[\mathrm{Al}(\mathrm{OH})_{n}\left(\mathrm{OH}_{2}\right)_{6-n}\right]^{(3-n)+}$

$\left[\mathrm{Al}(\mathrm{OH})_{n}\left(\mathrm{OH}_{2}\right)_{6-n}\right]^{[3-n)+} \stackrel{\text { se }}{\rightarrow} \mathrm{Al}+n \mathrm{OH}^{-}+(6-n)_{2} \mathrm{O} ; \quad n=1$ or 2 Proceeding towards negative potentials the rate of the liberation of $\mathrm{OH}^{-}$-ions increases, the bonded water molecules are deprived of $\mathrm{H}^{+}$-ions by the $\mathrm{OH}^{-}$-ions at the electrode surface, so that the $\mathrm{Al}^{3+}$ reduction becomes the only electrode reaction. As in aqueous solutions it is impossible to tion, i.e. of the reaction adic dissolution of aluminium, the rate of inactivawater leading to the formation of the hydrogen molecule and aluminium hydroxide, must be very rapid. Aluminium hydroxide is therefore the final product of the whole electrode process, which remains adsorbed at the surface as shown from $i-t$ curves and from microscopic observations.

Another proof of the direct reduction of the aluminium ion is based on the effect of the substitution of water molecules for various anions in the co-ordination sphere of the aluminium ion (Fir. 3). The addition of chlorides,

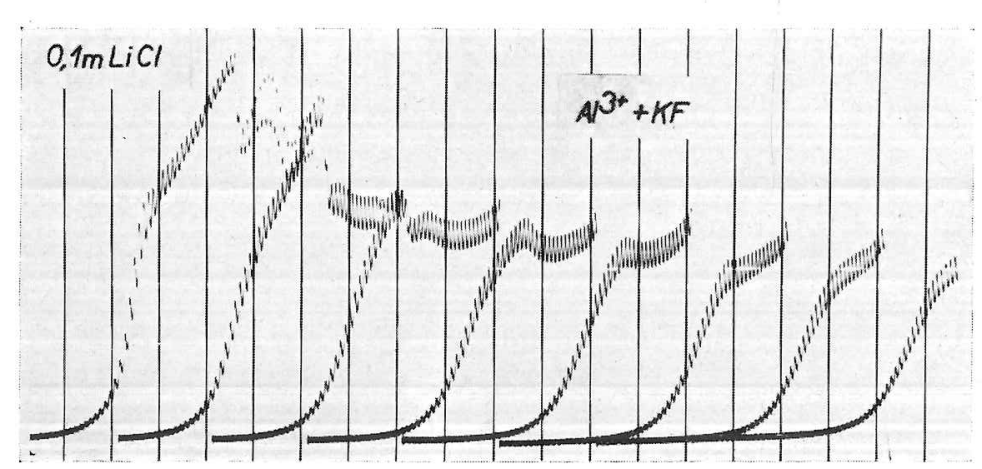

FrG. $3.4 \times 10^{-4} M \mathrm{KAl}\left(\mathrm{SO}_{4}\right)_{2}$ in $0.1 M \mathrm{LiCl}$; to $5 \mathrm{ml}$ of solution $7 \times$ added $0.2 \mathrm{ml}$
$10^{-2} M \mathrm{KF}$, curves registered from $1 \cdot 3 \mathrm{~V}$; $100 \mathrm{mV} /$ absc. anode-saturated

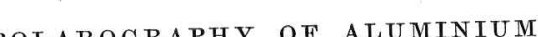

857

作, ox of fluorides, oxalates, tartrates, citrates in equivant concentration causes generally a change of the characteristic shape of the wave of the aquo-ions, and a shift of the wave to negative potentials; the important thing is that the height of the transformed wave corresponds still to a three-electron reduction, which can be explained only by the deposition of the central aluminium ion from the corresponding complex.

At the concentration of about $1.7 \times 10^{-4} \mathrm{M}$ of $\mathrm{Al}^{3+}$ there appears at the beginning of the polarographic wave a steep increase of current of an autocatalytic nature (Fig. 4). With the aid of a stationary mercury drop electrode this was found to be due to catalysis of the liberation of hydrogen-ions caused

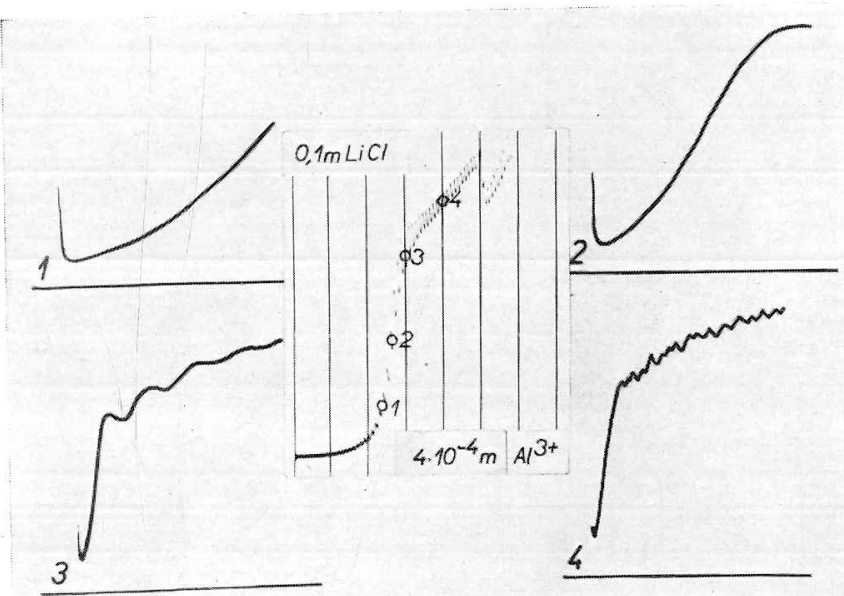

FIG. 4. Polarographic $i-E$ curve of a $4 \times 10^{-4} M$ solution of $\mathrm{KAl}_{1}\left(\mathrm{SO}_{4}\right)_{2}$ in $0.1 \mathrm{M}$
$\mathrm{LiCl}$ and four $i-t$ curves registered at denoted potentials; in absence of oxygen.

y the adsorption of aquoaluminium ions at the electrode surface. This adsorption of aluminium ions on the mercury electrode is evident from electrocapillary measurements ${ }^{3}$. When the alunin ion water molecules is adsorbed at the negative eloction, the hyde become loose and their reduction takes place at to the formula $i=k^{1 \cdot 25}$, The current at constant potential thes acotion becomes slackened by the but at more negative potentials the reaction becomes (Fig. 4). The new layer of the reduction product-aluninim hycotion and catalysis, and so surface of the increasing drop permits new adsorption an to periodic waves the succession of catalytio and scury drop is covered by a film of aluminium 
hydroxide, bursting and restoring itself again, which causes irregular and rapid movements of the surface of the drop, similarly as when at positive potentials a calomel film is forned. This motion becomes still more vigorous when the redue mo al does the movent a being totaly

covered by the adsorption layer of hylroxido from its vany beginning.

At higher concentrations the maximum does not reach the height of five electron, becruse the adsorbed alwin in the cle clearly seen on the concentrations.

After the first maximum there appears a second rounded one of catalytic that be due to another catalytic effect of aluminium ion occluded in the layer of aluminium hydroxide.

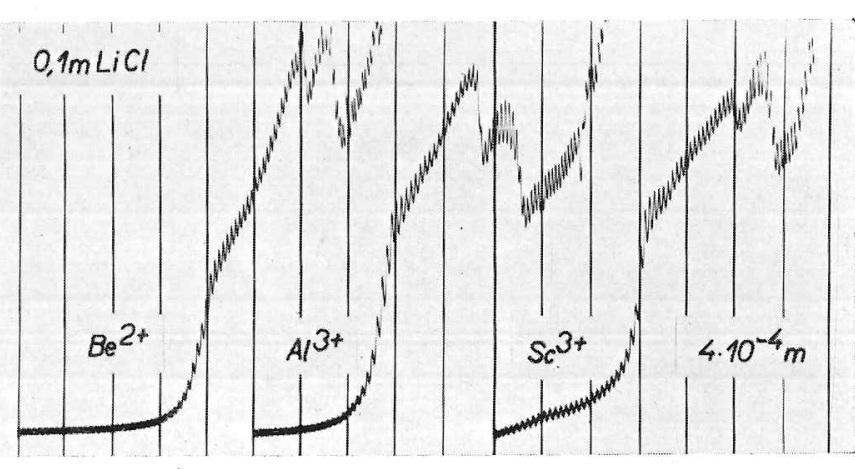

FIG. 5. Polarographic curves of $4 \times 10^{-4} M \mathrm{BeCl}_{2}, \mathrm{AlCl}_{3}, \mathrm{SeCl}_{3}$ in $0.1 \mathrm{MLiCl}$. All $1 / 20$; in absence of oxygen.

In solutions more concentrated than $10^{-3} M$ aluminium ions form polynuclear complexes through $-\mathrm{OH}$ bridges( ${ }^{4)}$; this is probably the cause of slowing down of the catalytic reaction and therefore of the decreasing slope of the polarographic wave.

This complicated reaction is in its main points of a more general character: beryllium and scandium ions, for instance, give polarographic waves of a very similar shape (Fig. 5); moreover, the sequence of $i-t$ curves with autocatalysis and periodic structure may be obtained also with various rare-earth elements.

If we repeat polarisation curves several times with the same electrode surface - be it with a higher frequency at the dropping mercury surface, or slowly on a stationary electrode, the reaction product-aluminium hydro-

xide covers the electrode and slackens further electrode reactions; after the forth or fifth cycle there is no sign of depolarisation. This is the reason why in the alternating current oscillography or

The The results are firstic phase of polarisation there oppers a curve at about

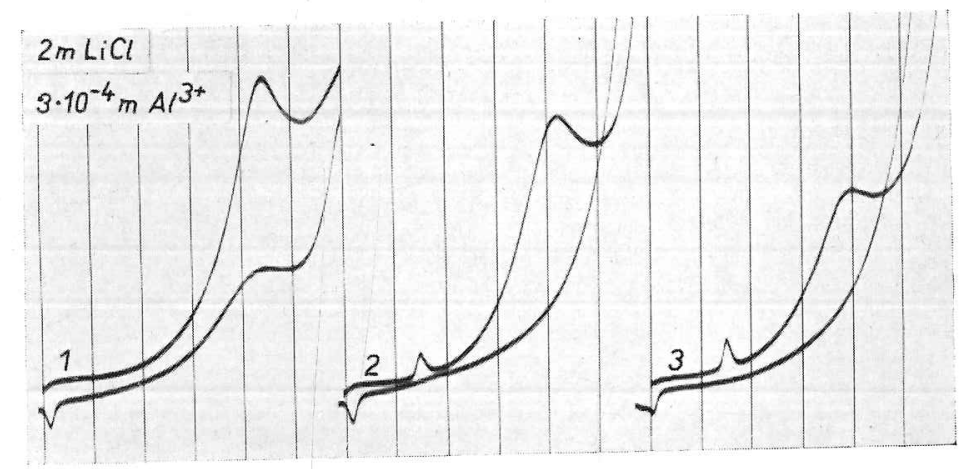

FIC. 6. Polarographic curves on one mercury drop; $3 \times 10^{-4} M \mathrm{KAl}\left(\mathrm{SO}_{4}\right)_{2}$ in
$2 M$ LiCl; one stationary mercury drop polarised cyclically from $-1 \cdot 0$ to $-1 \cdot 6 \mathrm{~V}$ (SCE) and back again in the sequence $1,2,3 ; 100 \mathrm{mV} /$ abse.; sensitivity $1 / 10$; in

$-1.05 \mathrm{~V}$. In the following cycle there is already a cathodic analogue of the peak $150 \mathrm{mV}$ more negative; with cyclically repeated polarisation the peaks grow to a constant height. The reaction causing this effect is a very mobile one, since the peaks appear on the polarising curves with the rate of potential variation $3 \mathrm{mV} / \mathrm{sec}$ as well as $6000 \mathrm{~V} / \mathrm{sec}$. A detailed study of this phenomenon leads to the conclusion that the peaks are caused by rapid changes of the capacity due to the adsorption and desorption of a surface film. Marnesium ion behaves similarly ; here the substance adsorbed is magnesium hydroxide $\mathrm{e}^{(3 b)}$. It is probable that in the case of lithium and aluminium at negative potentials the insoluble lithium aluminate is formed and adsorbed on the electrode surface. In the anodic phase at a certain potential it is desorbed or some sudden change of its structure takes place, whereas this change proceeds in the reverse sense at the cathodic phase.

REFERENCES

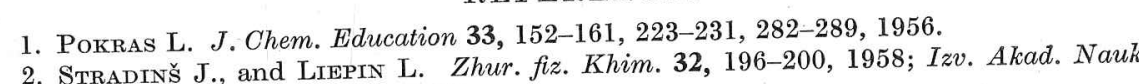
Latv. SSR R 134, 97-104, 1958.
HEXrovsKÝ M. Z. physik. Chem. (Leipzig), Sonderheft 97-107, 1958. 
860

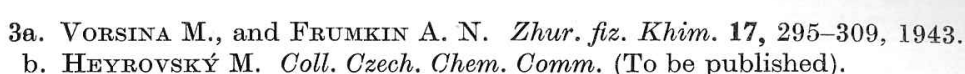

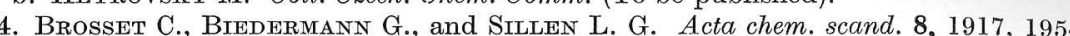
KвмUтA W., and Kublik Z. Roczniki Chem. 30, 1005, 1956; 31, 1085, 1957.

DISCUSSION

B. B. BAcH: Has the work on the polarography of aluminium led to a method

for determining it accurately?
M. HEYrovsK $\mathbf{x}$ : The height of the wave is proportional to concentration but interference nay bexperioth of
Reprint from

ADVANCES IN POLAROGRAPHY

Proceedings of the International Congress.
Cambridge, August $24-29 \mathrm{th}, 1959$

Perganow Press, Londow 1960
PR. D. Dissertation 